\title{
An Introduction to the Law of Afghanistan
}

\author{
Second Edition
}

\section{Statutory}

Supplement

Afghanistan Legal Education Project (ALEP)

at Stanford Law School

www.afghanistanlegaleducation.com

afghanistanlegaleducation@gmail.com

Stanford Law School

Crown Quadrangle

559 Nathan Abbott Way

Stanford, CA 94305-8610

www.law.stanford.edu

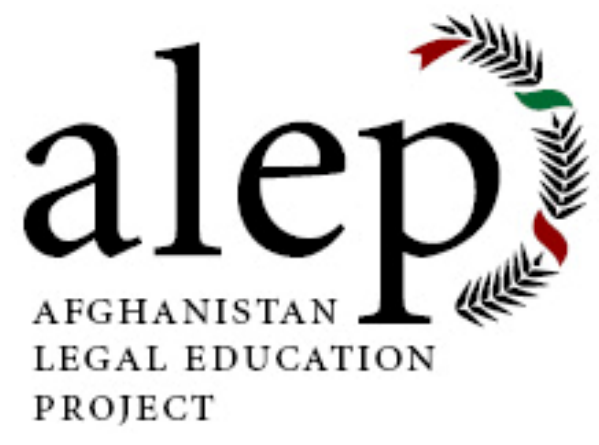




\section{STATUTORY SUPPLEMENT TO AN INTRODUCTION TO THE LAW OF AFGHANISTAN}

The Constitution of the Islamic Republic of Afghanistan .............................................. 1

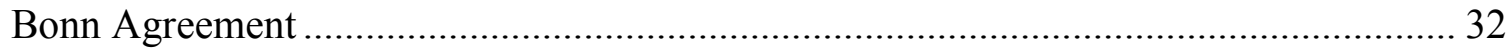

Law on Organization and Jurisdiction of Courts of Afghanistan .................................... 43

Excerpts from the Law of Commerce of Afghanistan of 1334....................................... 141

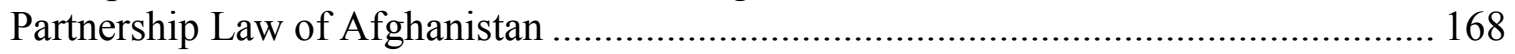

The Corporations and Limited Liability Companies Law of Afghanistan .................... 196

Private Investment Law .................................................................................... 223

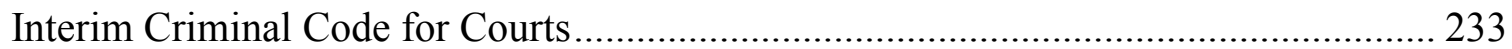

The Cairo Declaration on Human Rights in Islam................................................... 257

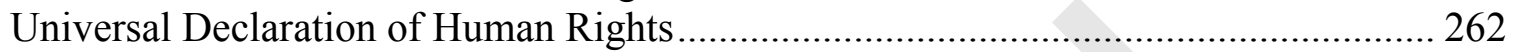




\title{
THE CONSTITUTION OF THE ISLAMIC REPUBLIC OF AFGHANISTAN
}

\author{
(Ratified) January 26, 2004
}

In the name of Allah, the Most Beneficent, the Most Merciful

\section{Contents}

Preamble

Chapter One: State (21 articles)

Chapter Two: Fundamental Rights and Duties of Citizens (38 articles)

Chapter Three: The President (11 articles)

Chapter Four: Government (10 articles)

Chapter Five: National Assembly (29 articles)

Chapter Six: Loya Jirga (6 articles)

Chapter Seven: The Judiciary (20 articles)

Chapter Eight: Administration (7 articles)

Chapter Nine: State of Emergency (6 articles)

Chapter Ten: Amendments (2 articles)

Chapter Eleven: Miscellaneous Provisions (7 articles)

Chapter Twelve: Transitional Provisions (5 articles)

\section{Preamble}

In the name of Allah, the Most Beneficient, the Most Merciful

Praise be to Allah, the Cherisher and Sustainer of Worlds; and Praise and Peace be upon

Mohammad, His Last Messenger and his disciples and followers

We the people of Afghanistan:

○ Believing firmly in Almighty God, relying on His divine will and adhering to the Holy religion of Islam;

- Realizing the previous injustices, miseries and innumerable disasters which have befallen our country;

- Appreciating the sacrifices, historical struggles, jihad and just resistance of all the peoples of Afghanistan, admiring the supreme position of the martyr's of the country's freedom;

- Comprehending that a united, indivisible Afghanistan belongs to all its tribes and peoples;

- Observing the United Nations Charter as well as the Universal Declaration of Human

And in order to: Rights;

- Strengthen national unity, safeguard independence, national sovereignty and territorial integrity of the country;

○ Establish an order based on the peoples' will and democracy; 
- Form a civil society void of oppression, atrocity, discrimination as well as violence, based on rule of law, social justice, protecting integrity and human rights, and attaining peoples' freedoms and fundamental rights;

- Strengthen political, social, economic as well as defense institutions;

- Attain a prosperous life and sound living environment for all inhabitants of this land;

- And, eventually, regain Afghanistan's appropriate place in the international family;

Have, herein, approved this constitution in accordance with the historical, cultural and social realities as well as requirements of time through our elected representatives in the Loya Jirga, dated January 3, 2004, held in the city of Kabul.

\section{Chapter One: State}

\section{Article One}

Afghanistan shall be an Islamic Republic, independent, unitary and indivisible state.

\section{Article Two}

The sacred religion of Islam is the religion of the Islamic Republic of Afghanistan. Followers of other faiths shall be free within the bounds of law in the exercise and performance of their religious rituals.

\section{Article Three}

No law shall contravene the tenets and provisions of the holy religion of Islam in Afghanistan.

\section{Article Four}

National sovereignty in Afghanistan shall belong to the nation, manifested directly and through its elected representatives. The nation of Afghanistan is composed of all individuals who possess the citizenship of Afghanistan. The nation of Afghanistan shall be comprised of Pashtun, Tajik, Hazara, Uzbek, Turkman, Baluch, Pachaie, Nuristani, Aymaq, Arab, Qirghiz, Qizilbash, Gujur, Brahwui and other tribes. The word Afghan shall apply to every citizen of Afghanistan. No individual of the nation of Afghanistan shall be deprived of citizenship. The citizenship and asylum related matters shall be regulated by law.

\section{Article Five}

Implementing the provisions of this constitution and other laws, defending independence, national sovereignty, territorial integrity and attaining the security and defense capability of the country shall be the fundamental duties of the state. 


\section{Article Six}

The state shall be obligated to create a prosperous and progressive society based on social justice, preservation of human dignity, protection of human rights, realization of democracy, attainment of national unity as well as equality between all peoples and tribes and balance development of all areas of the country.

\section{Article Seven}

The state shall observe the United Nations Charter, inter-state agreements, as well as international treaties to which Afghanistan has joined, and the Universal Declaration of Human Rights. The state shall prevent all kinds of terrorist activities, cultivation and smuggling of narcotics, and production and use of intoxicants.

\section{Article Eight}

The state shall regulate the foreign policy of the country on the basis of preserving the independence, national interests and territorial integrity as well as non-interference, good neighborliness, mutual respect and equality of rights.

\section{Article Nine}

Mines and other subterranean resources as well as historical relics shall be the property of the state. Protection, management and proper utilization of public properties as well as natural resources shall be regulated by law.

\section{Article Ten}

The state shall encourage, protect as well as ensure the safety of capital investment and private enterprises in accordance with the provisions of the law and market economy.

\section{Article Eleven}

Matters related to domestic as well as foreign trade shall be regulated by law in accordance with the economic requirements of the country and public interests.

\section{Article Twelve}

Da Afghanistan Bank shall be independent and the central bank of the state. Currency issuance as well as formulating and implementing the monetary policy of the country shall be, according to provisions of the law, the authority of the central bank. The central bank shall consult the economic committee of the House of People about printing of money. The organization and operation method of Central Bank shall be regulated by law. 


\section{Article Thirteen}

The state shall design and implement effective programs for developing industries, expanding production as well as protecting activities of craftsmen to raise the standard of living of the people.

\section{Article Fourteen}

The state, within its financial means, shall design and implement effective programs to develop agriculture and animal husbandry, improve economic, social and living conditions of farmers, herders and settlers as well as the nomads' livelihood. The state shall adopt necessary measures for provision of housing and distribution of public estates to deserving citizens in accordance with the provisions of law and within financial possibilities.

\section{Article Fifteen}

The state shall be obligated to adopt necessary measures to protect and improve forests as well as the living environment.

\section{Article Sixteen}

From amongst Pashto, Dari, Uzbeki, Turkmani, Baluchi, Pachaie, Nuristani, Pamiri and other current languages in the country, Pashto and Dari shall be the official languages of the state. In areas where the majority of the people speak in any one of Uzbeki, Turkmani, Pachaie, Nuristani, Baluchi or Pamiri languages, any of the aforementioned language, in addition to Pashto and Dari, shall be the third official language, the usage of which shall be regulated by law. The state shall design and apply effective programs to foster and develop all languages of Afghanistan. Usage of all current languages in the country shall be free in press publications and mass media. Academic and national administrative terminology and usage in the country shall be preserved.

\section{Article Seventeen}

The state shall adopt necessary measures to foster education at all levels, develop religious teachings, regulate and improve the conditions of mosques, religious schools as well as religious centers.

\section{Article Eighteen}

The source for the calendar year of the country shall be based upon the migration of The Prophet (PBUH). The basis for state offices shall be the solar calendar. Fridays, as well as the 28th of Asad and 8th of Saur, shall be public holidays. Other holidays shall be regulated by law. 


\section{Article Nineteen}

The flag of Afghanistan shall be made up of three equal parts, with black, red and green colors juxtaposed from left to right vertically. The width of every color shall be half of its length, and at the center of which the national insignia shall be located. The national insignia of Afghanistan shall be comprised of an emblem and a pulpit in white color - at the two corners of which are two flags, inscribed in the top middle the holy phrase "There is no God but Allah and Mohammad is his Prophet, and Allah is Great." This shall be inscribed and superseded on rays of a rising sun, and in its lower part, the year 1919 in the solar calendar, and the word "Afghanistan" encircled on two sides by sheaves of wheat shall be inscribed. The law shall regulate the use of the flag and insignia.

\section{Article Twenty}

The national anthem of Afghanistan shall be in Pashto with the mention of "God is Great" as well as the names of the tribes of Afghanistan.

Article Twenty-One

The capital of Afghanistan shall be the city of Kabul.

\section{Chapter Two: Fundamental Rights and Duties of Citizens}

\section{Article Twenty-Two}

Any kind of discrimination and distinction between citizens of Afghanistan shall be forbidden. The citizens of Afghanistan, man and woman, have equal rights and duties before the law.

Article Twenty-Three

Life is the gift of God as well as the natural right of human beings. No one shall be deprived of this except by legal provision.

\section{Article Twenty-Four}

Liberty is the natural right of human beings. This right has no limits unless affecting others freedoms as well as the public interest, which shall be regulated by law. Liberty and human dignity are inviolable. The state shall respect and protect liberty as well as human dignity.

\section{Article Twenty-Five}

Innocence is the original state. The accused shall be innocent until proven guilty by the order of an authoritative court.

Article Twenty-Six 
Crime is a personal act. Investigation, arrest and detention of an accused as well as penalty execution shall not incriminate another person.

\section{Article Twenty-Seven}

No deed shall be considered a crime unless ruled by a law promulgated prior to commitment of the offense. No one shall be pursued, arrested, or detained without due process of law. No one shall be punished without the decision of an authoritative court taken in accordance with the provisions of the law, promulgated prior to commitment of the offense.

\section{Article Twenty-Eight}

No citizen of Afghanistan accused of a crime shall be extradited to a foreign state without reciprocal arrangements as well as international treaties to which Afghanistan has joined. No Afghan shall be deprived of citizenship or sentenced to domestic or foreign exile.

\section{Article Twenty-Nine}

Persecution of human beings shall be forbidden. No one shall be allowed to or order torture, even for discovering the truth from another individual who is under investigation, arrest, detention or has been convicted to be punished. Punishment contrary to human dignity shall be prohibited.

\section{Article Thirty}

A statement, confession or testimony obtained from an accused or of another individual by means of compulsion shall be invalid. Confession to a crime is a voluntary admission before an authorized court by an accused in a sound state of mind.

\section{Article Thirty-One}

Upon arrest, or to prove truth, every individual can appoint a defense attorney. Immediately upon arrest, the accused shall have the right to be informed of the nature of the accusation, and appear before the court within the time limit specified by law. In criminal cases, the state shall appoint a defense attorney for the indigent. Confidentiality of conversations, correspondence, and communications between the accused and their attorney shall be secure from any kind of violation. The duties and powers of defense attorneys shall be regulated by law.

\section{Article Thirty-Two}

Debt shall not curtail or deprive the freedom of the individual. The method and means of recovering debt shall be regulated by law. 
Article Thirty-Three

The citizens of Afghanistan shall have the right to elect and be elected. The conditions of exercising this right shall be regulated by law.

\section{Article Thirty-Four}

Freedom of expression shall be inviolable. Every Afghan shall have the right to express thoughts through speech, writing, illustrations as well as other means in accordance with provisions of this constitution. Every Afghan shall have the right, according to provisions of law, to print and publish on subjects without prior submission to state authorities. Directives related to the press, radio and television as well as publications and other mass media shall be regulated by law.

\section{Article Thirty-Five}

To attain moral and material goals, the citizens of Afghanistan shall have the right to form associations in accordance with provisions of the law. The people of Afghanistan shall have the right, in accordance with provisions of the law, to form political parties, provided that:

1. Their manifesto and charter shall not contravene the Holy religion of Islam and principles and values enshrined in this constitution;

2. Their organizations and financial resources shall be transparent;

3. They shall not have military or quasi-military aims and organizations; and

4. They shall not be affiliated with foreign political parties or other sources.

Formation and operation of a party on the basis of tribalism, parochialism, language, as well as religious sectarianism shall not be permitted. A party or association formed according to provisions of the law shall not be dissolved without legal causes and the order of an authoritative court.

\section{Article Thirty-Six}

The people of Afghanistan shall have the right to gather and hold unarmed demonstrations, in accordance with the law, for attaining legitimate and peaceful purposes.

\section{Article Thirty-Seven}

Freedom and confidentiality of correspondence, as well as communications of individuals, whether in the form of a letter or via telephone, telegraph, as well as other means, shall be secure from intrusion. The state shall not have the right to inspect personal correspondence and communications, unless authorized by provisions of the law.

\section{Article Thirty-Eight}

Personal residences shall be immune from trespassing. No one, including the state, shall have the right to enter a personal residence or search it without the owners permission or by order of 
an authoritative court, except in situations and methods delineated by law. In case of an evident crime, the responsible official shall enter or search a personal residence without prior court order. The aforementioned official, shall, after entrance or completion of search, obtain a court order within the time limit set by law.

\section{Article Thirty-Nine}

Every Afghan shall have the right to travel and settle in any part of the country, except in areas forbidden by law. Every Afghan shall have the right to travel outside Afghanistan and return, according to the provisions of the law. The state shall protect the rights of the citizens of Afghanistan outside the country.

\section{Article Forty}

Property shall be safe from violation. No one shall be forbidden from owning property and acquiring it, unless limited by the provisions of law. No one's property shall be confiscated without the order of the law and decision of an authoritative court. Acquisition of private property shall be legally permitted only for the sake of public interests, and in exchange for prior and just compensation. Search and disclosure of private property shall be carried out in accordance with provisions of the law.

\section{Article Forty-One}

Foreign individuals shall not have the right to own immovable property in Afghanistan. Lease of immovable property for the purpose of capital investment shall be permitted in accordance with the provisions of the law. The sale of estates to diplomatic missions of foreign countries as well as international organization's to which Afghanistan is a member, shall be allowed in accordance with the provisions of the law.

\section{Article Forty-Two}

Every Afghan shall pay taxes and duties to the state in accordance with the provisions of the law. No taxes or duties shall be levied without legal representation. Tax rates and duties as well as the method of payment shall be determined, with due respect to social justice, by law. This provision shall also apply to foreign individuals and organizations. Every kind of tax, duty as well as paid incomes shall be deposited to a single state account.

\section{Article Forty-Three}

Education is the right of all citizens of Afghanistan, which shall be offered up to the B.A. level in the state educational institutes free of charge by the state. To expand balanced education as well as to provide mandatory intermediate education throughout Afghanistan, the state shall design and implement effective programs and prepare the ground for teaching mother tongues in areas where they are spoken. 


\section{Article Forty-Four}

The state shall devise and implement effective programs to create and foster balanced education for women, improve education of nomads as well as eliminate illiteracy in the country.

\section{Article Forty-Five}

The state shall devise and implement a unified educational curricula based on the tenets of the sacred religion of Islam, national culture as well as academic principles, and develop religious subjects curricula for schools on the basis of existing Islamic sects in Afghanistan.

\section{Article Forty-Six}

Establishing and administering higher, general and specialized educational institutions shall be the duty of the state. The citizens of Afghanistan shall establish higher, general and specialized educational as well as literacy institutions with permission of the state. The state shall permit foreign individuals to establish higher, general and specialized institutions in accordance with the provisions of the law. Admission terms to higher educational institutes of the state and other related matters shall be regulated by law.

\section{Article Forty-Seven}

The state shall devise effective programs for fostering knowledge, culture, literature and arts. The state shall guarantee the copyrights of authors, inventors and discoverers, and, shall encourage and protect scientific research in all fields, publicizing their results for effective use in accordance with the provisions of the law.

\section{Article Forty-Eight}

Work is the right of every Afghan. Working hours, paid holidays, employment and employee rights and related matters shall be regulated by the law. Choice of occupation and craft shall be free within the bounds of law.

\section{Article Forty-Nine}

Forced labor shall be forbidden. Active participation in times of war, disaster, and other situations that threaten public life and comfort shall be among the national duties of every Afghan. Forced labor on children shall not be allowed.

\section{Article Fifty}

The state shall adopt necessary measures to create a healthy administration and realize reforms in the administrative system of the country. The administration shall perform its duties with complete neutrality and in compliance with the provisions of the laws. The citizens of Afghanistan shall have the right of access to information from state departments in accordance with the provisions of the law. This right shall have no limit except when harming rights of 
others as well as public security. The citizens of Afghanistan shall be recruited by the state on the basis of ability, without any discrimination, according to the provisions of the law.

\section{Article Fifty-One}

Any individual suffering damage without due cause from the administration shall deserve compensation, and shall appeal to a court for acquisition. Except in conditions stipulated by law, the state shall not, without the order of an authoritative court, claim its rights.

\section{Article Fifty-Two}

The state shall provide free preventative healthcare and treatment of diseases as well as medical facilities to all citizens in accordance with the provisions the law. Establishment and expansion of private medical services as well as health centers shall be encouraged and protected by the state in accordance with the provisions of the law. The state shall adopt necessary measures to foster healthy physical education and development of the national as well as local sports.

\section{Articles Fifty-Three}

The state shall adopt necessary measures to regulate medical services as well as financial aid to survivors of martyrs and missing persons, and for reintegration of the disabled and handicapped and their active participation in society, $\mathrm{s}$ in accordance with provisions of the law. The state shall guarantee the rights of retirees, and shall render necessary aid to the elderly, women without caretaker, disabled and handicapped as well as poor orphans, in accordance with provisions of the law.

\section{Article Fifty-Four}

Family is the fundamental pillar of the society, and shall be protected by the state. The state shall adopt necessary measures to attain the physical and spiritual health of the family, especially of the child and mother, upbringing of children, as well as the elimination of related traditions contrary to the principles of the sacred religion of Islam.

\section{Article Fifty-Five}

Defending the country shall be the duty of all citizens of Afghanistan. Conditions for compulsory military service shall be regulated by law.

\section{Article Fifty-Six}

Observance of the provisions of the constitution, obedience of laws and respect of public order and security shall be the duty of all citizens of Afghanistan. Ignorance of the laws shall not be considered an excuse. 


\section{Article Fifty-Seven}

The state shall guarantee the rights and liberties of foreign citizens in Afghanistan in accordance with the law. These people shall be obliged to respect the laws of the state of Afghanistan within the limits of the provisions of international law.

\section{Article Fifty-Eight}

To monitor respect for human rights in Afghanistan as well as to foster and protect it, the state shall establish the Independent Human Rights Commission of Afghanistan. Every individual shall complain to this Commission about the violation of personal human rights. The Commission shall refer human rights violations of individuals to legal authorities and assist them in defense of their rights. Organization and method of operation of the Commission shall be regulated by law.

\section{Article Fifty-Nine}

No individual shall be allowed to manipulate the rights and liberties enshrined in this Constitution and act against independence, territorial integrity, sovereignty as well as national unity.

\section{Chapter Three: The President}

\section{Article Sixty}

The President shall be the head of state of the Islamic Republic of Afghanistan, executing his authorities in the executive, legislative and judiciary fields in accordance with the provisions of this Constitution. The President shall have two Vice-Presidents, first and second. The Presidential candidate shall declare to the nation names of both vice presidential running mates. In case of absence, resignation or death of the President, the first Vice-President shall act in accordance with the provisions of this Constitution. In the absence of the first Vice-President, the second Vice-President shall act in accordance with the provisions of this Constitution.

\section{Article Sixty-One}

The President shall be elected by receiving more than fifty percent of votes cast by voters through free, general, secret and direct voting. The presidential term shall expire on 1st of Jawza of the fifth year after elections. Elections for the new President shall be held within thirty to sixty days prior to the end of the presidential term. If in the first round none of the candidates gets more than fifty percent of the votes, elections for the second round shall be held within two weeks from the date election results are proclaimed, and, in this round, only two candidates who have received the highest number of votes in the first round shall participate. In case one of the presidential candidates dies during the first or second round of voting or after elections, but prior to the declaration of results, re-election shall be held according to provisions of the law. 


\section{Article Sixty-Two}

The individual who becomes a presidential candidate shall have the following qualifications:

1. Shall be a citizen of Afghanistan, Muslim, born of Afghan parents and shall not be a citizen of another country;

2. Shall not be less than forty years old the day of candidacy;

3. Shall not have been convicted of crimes against humanity, a criminal act or deprivation of civil rights by court.

No individual shall be elected for more than two terms as President. The provision of this article shall also apply to Vice-Presidents.

\section{Article Sixty-Three}

Before assuming office, the President shall take, in accordance with special procedures set by law, the following oath of allegiance:

"In the name of God, Most Gracious, Most Merciful, I swear by the name of God Almighty that I shall obey and protect the Holy religion of Islam, respect and supervise the implementation of the Constitution as well as other laws, safeguard the independence, national sovereignty and territorial integrity of Afghanistan, and, in seeking God Almighty's help and support of the nation, shall exert my efforts towards the prosperity and progress of the people of Afghanistan."

\section{Article Sixty-Four}

The President shall have the following authorities and duties:

4. Supervise the implementation of the Constitution;

5. Determine the fundamental lines of the policy of the country with the approval of the National Assembly;

6. Being the Commander in Chief of the armed forces of Afghanistan;

7. Declare war and peace with the endorsement of the National Assembly;

8. Take necessary decisions to defend territorial integrity and preserve independence;

9. Dispatch armed forces units outside of Afghanistan with the endorsement of the National Assembly;

10. Convene the Loya Jirga except in the situation prescribed in Article 69 of this Constitution;

11. Proclaim as well as terminate the state of emergency with the endorsement of the National Assembly;

12. Inaugurate the sessions of National Assembly and Loya Jirga.

13. Accept the resignations of vice-presidents of the Republic;

14. Appoint the Ministers, the Attorney General, the Head of the Central Bank, the National Security Director as well as the Head of the Red Cross with the endorsement of the House of People, and their dismissal and acceptance of resignation; 
15. Appoint the Justice of the Supreme Court as well as justices of the Supreme Court with the endorsement of the House of People;

16. Appointing, retiring and accepting the resignation and dismissal of judges, officers of the armed forces, police, national security as well as high ranking officials according to the provisions of law;

17. Appoint heads of political representatives of Afghanistan to foreign states as well as international organizations;

18. Accept credentials of foreign political representatives in Afghanistan;

19. Endorse laws as well as judicial decrees;

20. Issue credential letter for conclusion of international treaties in accordance with the provisions of the law;

21. Reduce and pardon penalties in accordance with the provisions of the law;

22. Bestow medals, insignias as well as honorary titles in accordance with the provisions of the law;

23. Establish commissions to improve the administration of the country in accordance with the provisions of the law;

24. Perform other authorities and duties enshrined in this Constitution.

\section{Article Sixty-Five}

On important national, political, social as well as economic issues the President can call for a referendum of the people of Afghanistan. The referendum shall not be contrary to the provisions of this Constitution or require its amendment.

\section{Article Sixty-Six}

The President shall take into consideration the supreme interests of the people of Afghanistan to enforce the authorities enshrined in this Constitution. The President shall not sell or bestow state properties without the provision of the law. During the term of office, the Presidential position shall not be used for linguistic, sectarian, tribal, and religious as well as party considerations.

\section{Article Sixty-Seven}

In case of resignation, impeachment or death of the President, as well as an incurable illness impeding performance of duty, the First Vice-President shall assume authorities and duties of the President. The President shall personally tender resignation to the National Assembly.

Affirmation of an incurable illness shall be verified by an authoritative medical team assigned by the Supreme Court. In such cases, elections for the new President shall be held within three months in accordance with Article Sixty-One of the Constitution. The First Vice-President, in acting as interim President, shall not perform the following duties:

1. Amend the Constitution;

2. Dismiss ministers;

3. Call a referendum. 
The Vice-Presidents can according to the provisions of this Constitution, nominate themselves as presidential candidates. In the absence of the President, the duties of the First Vice-President shall be determined by the President.

\section{Article Sixty-Eight}

In case any of the Vice-Presidents resign or die, another person shall be appointed by the President with the endorsement of the House of the People. In case of simultaneous death of the President and the First Vice-President, the Second Vice-President, the President of the House of Elders, the President of the House of Representatives and the Foreign Minister shall succeed respectively and, in that order, and, according to Article Sixty-Seven of this Constitution, shall assume the duties of the President.

\section{Article Sixty-Nine}

The President shall be responsible to the nation as well as the House of People in accordance with the provisions of this Article. Accusations of crimes against humanity, national treason as well as a crime against the President shall be demanded by one third of all members of the House of People. If this demand is approved by two thirds of the House of People, the House of People shall convene the Loya Jirga within one month.

If the Loya Jirga, by two-thirds majority, approves the accusation, the President shall be released from duty and the issue shall be referred to a special court, which shall be comprised of the President of the House of Elders, three members of the House of People, and three members of the Supreme Court appointed by the Loya Jirga. The case shall be presented by the individual appointed by the Loya Jirga. In such a situation the provisions of Article Sixty-Seven of this Constitution shall be applied.

\section{Article Seventy}

The salary and expenses of the President shall be regulated by law. The President, after completion of his term of service, except when dismissed, shall be entitled to financial benefits of the presidency for the rest of his life in accordance with the law.

\section{Chapter Four: Government}

\section{Article Seventy-One}

The Government shall be comprised of Ministers who work under the chairmanship of the President. The number of Ministers as well as their duties shall be regulated by law.

\section{Article Seventy-Two}

The individual appointed as Minister shall have the following qualifications: 
1. Shall have only the citizenship of Afghanistan; if the ministerial candidate has the citizenship of another country as well, the House of People shall have the right to approve or reject the nomination;

2. Shall have higher education, work experience as well as a good reputation;

3. Shall not be less than thirty five years of age;

4. Shall not have been convicted of crimes against humanity, a criminal act or deprivation of civil rights by a court.

Article Seventy-Three

The Ministers shall be appointed from amongst members of the National Assembly or outside. If a member of the National Assembly is appointed as Minister, that individual loses membership in the National Assembly and instead, another individual shall be appointed in accordance with the provisions of the law.

\section{Article Seventy-Four}

Before assuming office, the Ministers shall take the following oath in the presence of the President:

"In the name of God, Most Gracious, Most Merciful, I swear in the name of God Almighty that I shall protect the Holy religion of Islam, respect the Constitution and other laws of Afghanistan, safeguard the rights of citizens as well as independence, territorial integrity and the national unity of the people of Afghanistan, and, in all my deeds consider the Almighty's presence, performing the entrusted duties honestly."

\section{Article Seventy-Five}

The Government shall have the following duties:

1. Execute the provisions of this Constitution, other laws, as well as the final decisions of the courts;

2. Preserve the independence, defend the territorial integrity and safeguard the interests and prestige of Afghanistan in the international community;

3. Maintain public law and order and eliminate every kind of administrative corruption;

4. Prepare the budget, regulate financial conditions of the state as well as protect public wealth;

5. Devise and implement social, cultural, economic and technological development programs;

6. Report to the National Assembly, at the end of the fiscal year, about the tasks achieved as well as important programs for the new fiscal year;

7. Perform other duties that, in accordance with this Constitution and other laws, fall within the Government responsibilities. 


\section{Article Seventy-Six}

To implement the fundamental lines of the policy of the country and regulate its duties, the government shall devise as well as approve regulations, which shall not be contrary to the body or spirit of any law.

\section{Article Seventy-Seven}

The Ministers shall perform their duties as heads of administrative units within the framework of this Constitution as well as other laws prescribe. The Ministers shall be responsible to the President and House of Representatives for their specified duties.

\section{Article Seventy-Eight}

If a Minister is accused of crimes against humanity, national treason or other crimes, the case, in accordance with Article One Hundred Thirty Four of this Constitution, shall be submitted to a special court.

\section{Article Seventy-Nine}

During the recess of the House of Representatives, the Government shall, in case of an immediate need, issue legislative decrees, except in matters related to budget and financial affairs. Legislative decrees, after endorsement by the President, shall acquire the force of law. Legislative decrees shall be presented to the National Assembly within thirty days of convening its first session, and if rejected by the National Assembly, they become void.

\section{Article Eighty}

During their tour of duty, the Ministers shall not use their positions for linguistic, sectarian, tribal, religious or partisan purposes.

\section{Chapter Five: National Assembly}

\section{Article Eighty-One}

The National Assembly of the Islamic Republic of Afghanistan, as the highest legislative organ, shall manifest the will of its people as well as represent the entire nation.

Every member of the Assembly, when voting, shall judge according to the general interests as well as the supreme benefits of the people of Afghanistan.

\section{Article Eighty-Two}

The National Assembly consists of two houses: House of People and House of Elders. No individual shall be a member of both houses at the same time. 


\section{Article Eighty-Three}

Members of the House of People shall be elected by the people through free, general, secret and direct balloting. The work period of the House of People shall terminate, after the disclosure of the results of the elections, on the 1st of Saratan of the fifth year and the new parliament shall commence work. The elections for members of the House of People shall be held 30-60 days prior to the expiration of the term of the House of People.

The number of the members of the House of People shall be proportionate to the population of each constituency, not exceeding the maximum of two hundred fifty individuals. Electoral constituencies as well as other related issues shall be determined by the elections law. The elections law shall adopt measures to attain, through the electorate system, general and fair representation for all the people of the country, and proportionate to the population of every province, on average, at least two females shall be the elected members of the House of People from each province.

\section{Article Eighty-Four}

Members of the House of Elders shall be elected and appointed as follows:

1. From amongst each provincial council members, one individual shall be elected by the respective council for a four year term;

2. From amongst district councils of each province, one individual, elected by the respective councils, for a three year term;

3. The remaining one third of the members shall be appointed by the President, for a five year term, from amongst experts and experienced personalities, including two members from amongst the impaired and handicapped, as well as two from nomads.

The President shall appoint fifty percent of these individuals from amongst women. The individual selected as a member of the House of Elders shall lose membership to the related Council, and, another individual shall be appointed in accordance with the provisions of the law.

\section{Article Eighty-Five}

The individual who becomes a candidate or appointed to the membership of the National Assembly, in addition to the completion of the conditions of the election, shall have the following qualifications:

1. Shall be a citizen of Afghanistan or shall have obtained citizenship of the state of Afghanistan at least ten years prior to candidacy date or appointment;

2. Shall not have been convicted of crimes against humanity, as well as a crime or deprivation from civil rights by a court;

3. Shall have completed twenty-five years of age on candidacy day for the House of People, and thirty-five years on candidacy day or appointment for the House of Elders. 


\section{Article Eighty-Six}

Elections credentials of members of the National Assembly shall be reviewed by the Independent Elections Commission in accordance with the provisions of the law.

\section{Article Eighty-Seven}

Each of the two houses of the National Assembly, at the commencement of their work period, shall elect one member as president for the term of the legislature, and two members as first and second deputies and two members as secretary and assistant secretary for a period of one year. These individuals shall form the administrative teams of the House of People as well as House of Elders. Duties of the administrative teams shall be determined by the Regulations on Internal Duties of each house.

\section{Article Eighty-Eight}

Each of the two houses of the National Assembly shall form commissions to study issues under discussion in accordance with the Regulations of Internal Duties.

\section{Article Eighty-Nine}

The House of People shall have the authority to establish a special commission, on the proposal of one third of its members, to review as well as investigate the actions of the Government. The composition and method of operation of the aforementioned commission shall be determined by the Regulations on Internal Duties.

\section{Article Ninety}

The National Assembly shall have the following duties:

1. Ratification, modification or abrogation of laws or legislative decrees;

2. Approval of social, cultural, economic as well as technological development programs;

3. Approval of the state budget as well as permission to obtain or grant loans;

4. Creation, modification and or abrogation of administrative units;

5. Ratification of international treaties and agreements, or abrogation of membership of Afghanistan in them;

6. Other authorities enshrined in this Constitution.

Article Ninety-One

The House of People shall have the following special authorities:

1. Decide about elucidation session from each Minister in accordance with Article Ninety-Two of this Constitution;

2. Decide on the development programs as well as the state budget; 
3. Approve or reject appointments according to provisions of this Constitution.

Article Ninety-Two

The House of People, on the proposal of twenty percent of all its members, shall make inquiries from each Minister. If the explanations given are not satisfactory, the House of People shall consider the issue of a no- confidence vote. The no- confidence vote on a Minister shall be explicit, direct, as well as based on convincing reasons. The vote shall be approved by the majority of all members of the House of People.

Article Ninety-Three

Any commission of both houses of the parliament can question any Minister about special issues. The individual questioned shall provide an oral or written response.

Article Ninety-Four

Law shall be what both houses of the National Assembly approve and the President endorses, unless this Constitution states otherwise. In case the President rejects what the National Assembly has approved, the President shall send it back, within fifteen days from the date it was presented, to the House of People mentioning the reasons for rejection, and, with expiration of the period or if the House of People re-approves it with two thirds of all the votes, the draft shall be considered endorsed and enforceable.

\section{Article Ninety-Five}

The proposal for drafting laws shall be made by the Government or members of the National Assembly or, in the domain of regulating the judiciary, by the Supreme Court, through the Government. Proposals for drafting the budget and financial affairs laws shall be made only by the Government.

\section{Article Ninety-Six}

If the proposal for drafting a law includes imposition of new taxes or reduction of state incomes, it shall be included in the work agenda of the National Assembly on condition the compensation source shall also be forecasted in the text of the proposal.

\section{Article Ninety-Seven}

Proposals for drafting laws shall be first submitted to the House of People by the government. The House of People shall consider the draft laws, including budgetary and financial affairs as well as the proposal for obtaining or granting loans, and, after debate, either approve or reject as a whole. The House of People shall not delay more than one month the draft proposal. The House of People, after approving the proposed draft, shall send it to the House of the Elders. The House of Elders shall decide on it within fifteen days. In deciding about the proposed laws, the National Assembly shall give priority to treaties and development programs of the state that, 
according to the proposal of the government, require urgent consideration. If the proposal for drafting a law is made by ten members of either of the two houses, it shall be, after approval of one fifth of the House where it was initiated, included in the work agenda of that House.

\section{Article Ninety-Eight}

The state budget and development program of the government shall be submitted, through the House of Elders to the House of People along with its advisory views.

The decision of the House of People shall be implemented without presentation to the House of Elders, after endorsement by the President. If for some reasons the budget is not approved before the beginning of the new fiscal year, the budget of the year before shall be applied pending the passage of the new budget. The Government shall present during the fourth quarter of the financial year the budget for the next year, with the brief account of the current year budget, to the National Assembly. The precise account of the previous year financial budget shall be presented to the National Assembly during the next six months according to the provisions of the law. The House of People shall not delay approval of the budget for more than one month after receiving it and give permission to obtain or grant loans not included in the budget, for more than fifteen days.

If the House of People during this period does not decide on obtaining or granting loans, the proposal shall be considered approved.

\section{Article Ninety-Nine}

If, during the sessions of the National Assembly, the annual budget, or development program, or issues related to national security, territorial integrity and independence of the country is under discussion, the sessions of the Assembly shall not end pending decision of the matter.

\section{Article One Hundred}

If one House rejects decisions of the other, a joint commission comprised of an equal number of members from each House shall be formed to solve the difference. The decision of the commission, after endorsement by the President, shall be enforced. If the joint commission does not solve the difference, the decision shall be considered rejected. In such situation, the House of People shall pass it with two-thirds majority in its next session. This decision, without submission to the House of Elders, shall be promulgated once endorsement by the President.

\section{Article One Hundred One}

No member of the National Assembly shall be legally prosecuted for reasons of voting or views expressed during performance of duty.

\section{Article One Hundred Two}

If a member of the National Assembly is accused of a crime, the responsible official shall inform the House of which the accused is a member, and the accused shall be legally prosecuted. In 
case of an evident crime, the responsible official shall legally pursue and arrest the accused without the permission of the House of which the accused is a member.

In both cases, if the legal prosecution requires detention, the responsible official shall immediately inform the respective House and obtain its approval. If the accusation takes place during an Assembly recess, the permission for arrest or detention shall be obtained from the administrative board of the respective House, and the issue shall be referred to the first session of the aforementioned House for decision.

\section{Article One Hundred Three}

The Ministers can participate in the sessions of either House of the National Assembly. Either House of the National Assembly can demand the participation of the Ministers in its session.

\section{Article One Hundred Four}

Both Houses of the National Assembly shall convene their sessions concurrently, but separately. Sessions of the two Houses shall be held jointly under the following circumstances:

1. When the legislative term or annual sessions are inaugurated by the President;

2. When deemed necessary by the President.

3. The President of the House of People shall preside over the joint sessions of the National Assembly.

\section{Article One Hundred Five}

The sessions of the National Assembly shall be open unless the President of the Assembly or at least ten members of the National Assembly request their secrecy and the Assembly grants their request. No one shall enter the National Assembly building by force.

\section{Article One Hundred Six}

The quorum for voting of each House of the National Assembly shall be complete with the majority presence of members and decisions shall be taken with the majority of votes of members present, unless this Constitution states otherwise.

\section{Article One Hundred Seven}

The National Assembly shall hold two regular sessions annually. The term of both regular sessions shall be nine months every year, and when needed, the Assembly shall extend its term. Extraordinary sessions of the Assembly during recess shall be convened by Presidential order.

\section{Article One Hundred Eight}

In cases of death, resignation, and dismissal of a member of the National Assembly or disability or handicap, which impedes permanent performance of duty, the placement of the new representative for the remaining period of the legislative term shall be in accordance with 
provisions of the law. Matters related to the presence and absence of members of the National Assembly shall be regulated by the Internal Duties Statute.

Article One Hundred Nine

Proposals for amending elections law shall not be included in the work agenda of the National Assembly during the last year of the legislative term.

\section{Chapter Six: Loya Jirga}

Article One Hundred Ten

The Loya Jirga is the highest manifestation of the will of the people of Afghanistan. The Loya Jirga consists of:

1. Members of the National Assembly;

2. Presidents of the provincial as well as district assemblies.

Ministers, Chief Justice and members of the Supreme Court as well as the attorney general shall participate in the Loya Jirga sessions without voting rights.

Article One Hundred Eleven

The Loya Jirga shall convene in the following situations:

1. To decide on issues related to independence, national sovereignty, territorial integrity as well as supreme national interests;

2. Amend provisions of this Constitution;

3. Impeach the President in accordance with the provisions of Article Sixty Nine of the Constitution.

Article One Hundred Twelve

In its first session, the Loya Jirga shall elect, from amongst its members, a Chairperson, a Deputy-Chair, and a Secretary and an Assistant Secretary.

Article One Hundred Thirteen

The quorum of the Loya Jirga shall be complete for voting with the presence of the majority of members. The decision of the Loya Jirga, except in situations explicitly stated in this Constitution, shall be adopted by a majority of members present.

Article One Hundred Fourteen

Sessions of the Loya Jirga shall be open unless one fourth of its membership demand secrecy, and the Loya Jirga accept this demand. 
Article One Hundred Fifteen

During the sessions of the Loya Jirga, provisions of Articles One Hundred One and One Hundred Two of this Constitution shall be applied to its members.

\section{Chapter Seven: The Judiciary}

\section{Article One Hundred Sixteen}

The judiciary shall be an independent organ of the state of the Islamic Republic of Afghanistan. The judiciary shall be comprised of one Supreme Court, Courts of Appeal as well as Primary Courts whose organization and authority shall be regulated by law. The Supreme Court shall be the highest judicial organ, heading the judicial power of the Islamic Republic of Afghanistan.

Article One Hundred Seventeen

The Supreme Court shall be comprised of nine members, appointed by the President and with the endorsement of the House of People, and in observance of the provisions of clause three of Article Fifty as well as Article One Hundred Eighteen of this Constitution, shall be initially appointed in the following manner:

Three members for a period of four years, three members for seven years, and three members for ten years. Later appointments shall be for period of ten years. Appointment of members for a second term shall not be permitted.

The President shall appoint one of its members as Chief Justice of the Supreme Court. Members of the Supreme Court, except under circumstances stated in Article One Hundred Twenty Seven of this Constitution, shall not be dismissed till the end of their term.

Article One Hundred Eighteen

Supreme Court members shall have the following qualifications:

1. At time of appointment the age of the Chief Justice of the Supreme Court and its members shall not be less than forty year.

2. Shall be a citizen of Afghanistan.

3. Shall have higher education in legal studies or Islamic jurisprudence as well as expertise and adequate experience in the judicial system of Afghanistan.

4. Shall have good character as well as good reputation.

5. Shall not have been convicted, by a court, for crimes against humanity, crimes, or deprivation of civil rights.

6. Shall not be a member of any political party during his term of duty.

Article One Hundred Nineteen 
Members of the Supreme Court shall take the following oath of office in the presence of the President:

"In the of God, Most Gracious, Most Merciful, I swear in the name of God Almighty to attain justice and righteousness in accordance with tenets of the Holy religion of Islam, provisions of this Constitution as well as other laws of Afghanistan, and to execute the judicial duty with utmost honesty, righteousness and impartiality."

Article One Hundred Twenty

The authority of the judicial organ shall include consideration of all cases filed by real or incorporeal persons, including the state, as plaintiffs or defendants, before the court in accordance with the provisions of the law.

Article One Hundred Twenty-One

At the request of the Government, or courts, the Supreme Court shall review the laws, legislative decrees, international treaties as well as international covenants for their compliance with the Constitution and their interpretation in accordance with the law.

Article One Hundred Twenty-Two

No law shall, under any circumstances, exclude any case or area from the jurisdiction of the judicial organ as defined in this chapter and submit it to another authority. This provision shall not prevent formation of special courts stipulated in Articles Sixty- Nine, Seventy-Eight and One Hundred Twenty Seven of this Constitution, as well as cases related to military courts. The organization and authority of these courts shall be regulated by law.

Article One Hundred Twenty-Three

With respect to the provisions of this Constitution, statutes related to the formation, authority, as well as proceedings of courts and matters related to judges, shall be regulated by law.

Article One Hundred Twenty-Four

Provision of Laws related to civil servants as well as other administrative staff of the state shall also apply to the officials and the administrative personnel of the judiciary; but the Supreme Court in accordance with the law shall regulate their appointment, dismissal, promotion, retirement, rewards and punishments.

Article One Hundred Twenty-Five

The budget of the judiciary shall be prepared by the Supreme Court in consultation with the Government, and shall be presented to the National Assembly as part of the national budget. The Supreme Court shall implement the budget of the judiciary. 
Article One Hundred and Twenty-Six

Supreme Court judges shall receive lifetime pensions at the end of their term of service provided they do not hold state and political offices.

Article One Hundred Twenty-Seven

If more than one third of the members of the House of People demand the trial of the Chief Justice of the Supreme Court or any of its members accused of a crime related to job performance or committing a crime, and, the House of People approves this demand by two thirds majority of all members, the accused shall be dismissed and the issue referred to a special court. The formation of the court and procedure of the trial shall be regulated by law.

\section{Article One Hundred Twenty-Eight}

In the courts in Afghanistan, trials shall be held openly and every individual shall have the right to attend in accordance with the law. In situations clarified by law, the court shall hold secret trials when it considers necessary, but pronouncement of its decision shall be open in all cases.

Article One Hundred Twenty-Nine

In issuing decision, the court is obligated to state the reason for its verdict. All final decisions of the courts shall be enforced, except for capital punishment, which shall require Presidential approval.

Article One Hundred Thirty

In cases under consideration, the courts shall apply provisions of this Constitution as well as other laws. If there is no provision in the Constitution or other laws about a case, the courts shall, in pursuance of Hanafi jurisprudence, and, within the limits set by this Constitution, rule in a way that attains justice in the best manner.

\section{Article One Hundred Thirty-One}

The courts shall apply the Shia jurisprudence in cases involving personal matters of followers of the Shia sect in accordance with the provisions of the law. In other cases, if no clarification in this Constitution and other laws exist, the courts shall rule according to laws of this sect.

Article One Hundred Thirty-Two

Judges are appointed at the proposal of the Supreme Court and approval of the President. Appointment, transfer, promotion, punishment and proposals for retirement of judges, carried out according to provisions of the laws, shall be within the authority of the Supreme Court. To better regulate judicial as well as judicial administrative matters and attain necessary reforms, the Supreme Court shall establish the Office of General Administration of the Judiciary. 
Article One Hundred Thirty-Three

When a judge is accused of a crime, the Supreme Court shall, in accordance with the provisions of the law, consider the case. After hearing the defense, if the Supreme Court considers the accusation valid, it shall present a proposal to the President for dismissal of the judge. After Presidential approval, the accused judge shall be dismissed and punished according to the provisions of the law.

\section{Article One Hundred Thirty-Four}

Discovery of crimes shall be the duty of police, and investigation and filing the case against the accused in the court shall be the responsibility of the Attorney's Office, in accordance with the provisions of the law. The Attorney's Office shall be part of the Executive organ and shall be independent in its performance. The organization, authority as well as method of work of the Attorney's Office shall be regulated by law. Special law shall regulate discovery and investigation of crimes of duty by the armed forces, police and officials of national security.

\section{Article One Hundred Thirty-Five}

If a party in lawsuit does not know the language, the right to know the materials and documents of the case as well as conversation in the court, shall be provided in the party's mother tongue through a translator appointed by the court.

\section{Chapter Eight: Administration}

Article One Hundred Thirty-Six

The administration of the Islamic Republic of Afghanistan, based on the units of the central government and local offices, shall be regulated according to the law. The central administration shall be divided into several administrative units, each headed by a Minister. The local administrative unit shall be a province. The number, area, divisions and related provincial organizations as well as number of offices shall be regulated on the basis of population, social and economic conditions, as well as geographical location.

\section{Article One Hundred Thirty-Seven}

The government, in preserving the principles of centralism, shall transfer necessary powers, in accordance with the law, to local administrations in order to accelerate and improve economic, social as well as cultural matters, and foster peoples' participation in developing national life.

\section{Article One Hundred Thirty-Eight}

There shall be a provincial council in every province. Members of the provincial councils according to law, shall be elected for four years by the residents of the province, proportionate to the population, through free, general, secret as well as direct elections. The provincial council shall elect one of its members as President. 
Article One Hundred Thirty-Nine

The provincial council shall participate in the attainment of the development objectives of the state and improvement of the affairs of the province in the manner prescribe by laws, and shall advise the provincial administrations on related issues. The provincial assembly council shall perform its duties with the cooperation of the provincial administration.

\section{Article One Hundred Forty}

Councils shall be established to organize activities as well as attain active participation of the people in provincial administrations in districts and in villages, in accordance with the provisions of the law. Local residents shall elect members of these councils for three years through free, general, secret as well as direct elections. Participation of nomads in these local councils shall be regulated in accordance with the provisions of the law.

Article One Hundred Forty-One

To administer city affairs, municipalities shall be established. The mayor and members of municipal councils shall be elected through free, general, secret and direct elections. Matters related to municipalities shall be regulated by law.

Article One Hundred Forty-Two

To implement the provisions as well as attain values enshrined in this Constitution, the state shall establish necessary offices.

\section{Chapter Nine: State of Emergency}

\section{Article One Hundred Forty-Three}

If because of war, threat of war, serious rebellion, natural disasters or similar conditions, protection of independence and national life become impossible through the channels specified in this Constitution, the state of emergency shall be proclaimed by the President, throughout the country or part thereof, with endorsement of the National Assembly. If the state of emergency continues for more than two months, the consent of the National Assembly shall be required for its extension.

\section{Article One Hundred Forty-Four}

During the state of emergency, the President can, in consultation with the presidents of the National Assembly as well as the Chief Justice of the Supreme Court, transfer some powers of the National Assembly to the government.

Article One Hundred Forty-Five 
During the state of emergency, the President can, after approval by the presidents of the National Assembly as well as the Chief Justice of the Supreme Court, suspend the enforcement of the following provisions or place restrictions on them:

1. Clause Two of Article Twenty-Seven;

2. Article Thirty-Six;

3. Clause Two of Article Thirty-Seven;

4. Clause Two of Article Thirty-Eight.

Article One Hundred Forty-Six

The Constitution shall not be amended during the state of emergency.

Article One Hundred Forty-Seven

If the presidential term or the legislative term of the National Assembly expires during the state of emergency, the new general elections shall be postponed, and the presidential as well as parliamentary terms shall extend up to four months. If the state of emergency continues for more than four months, the President shall call the Loya Jirga. Within two months after the termination of the state of emergency, elections shall be held.

Article One Hundred Forty-Eight

At the termination of the state of emergency, measures adopted under Article One Hundred Forty-Four and One Hundred Forty-Five of this Constitution shall be void immediately.

\section{Chapter Ten: Amendments}

Article One Hundred Forty-Nine

The principles of adherence to the tenets of the Holy religion of Islam as well as Islamic Republicanism shall not be amended. Amending fundamental rights of the people shall be permitted only to improve them. Amending other articles of this Constitution, with due respect to new experiences and requirements of the time, as well as provisions of Articles Sixty-Seven and One Hundred Forty-Six of this Constitution, shall become effective with the proposal of the President and approval of the majority of National Assembly members.

Article One Hundred Fifty

To process the amendment proposals, a commission comprised of members of the Government, National Assembly as well as the Supreme Court shall be formed by presidential decree to prepare the draft proposal. To approve the amendment, the Loya Jirga shall be convened by a Presidential decree in accordance with the provisions of the Chapter on Loya Jirga. If the Loya Jirga approves the amendment with the majority of two thirds of its members, the President shall enforce it after endorsement. 


\title{
Chapter Eleven: Miscellaneous Provisions
}

\author{
Article One Hundred Fifty-One
}

The President, Vice-Presidents, Ministers, Chief Justice and members of the Supreme Court, the Attorney General, Heads of the Central Bank and National Directorate of Security, Governors and Mayors, during their term of offices, shall not engage in any profitable business with the state.

Article One Hundred Fifty-Two

The President, Vice-Presidents, Ministers, Chief Justice and members of the Supreme Court, Presidents and members of the National Assembly, the Attorney General and judges shall not engage in other jobs during their term of office.

Article One Hundred Fifty-Three

Judges, Attorneys, Officers of the Armed Forces, Police and officials of the National Security shall not become members of political parties during their term of office.

Article One Hundred Fifty-Four

The wealth of the President, Vice-Presidents, Ministers, members of the Supreme Court as well as the Attorney General, shall be registered, reviewed and published prior to and after their term of office by an organ established by law.

\section{Article One Hundred Fifty-Five}

Suitable salaries shall be fixed for Vice-Presidents, Ministers, Presidents, as well as members of the National Assembly and Supreme Court, judges, and Attorney General in accordance with the provisions of the law.

\section{Article One Hundred Fifty-Six}

The Independent Elections Commission shall be established to administer and supervise every kind of elections as well as refer to general public opinion of the people in accordance with the provisions of the law.

\section{Article One Hundred Fifty-Seven}

The Independent Commission for supervision of the implementation of the Constitution shall be established in accordance with the provisions of the law. Members of this Commission shall be appointed by the President with the endorsement of the House of People.

\section{Chapter Twelve: Transitional Provisions}


Article One Hundred Fifty-Eight

The title of the Father of the Nation and privileges bestowed upon His Majesty Mohammad Zahir Shah, the former King of Afghanistan, by the Emergency Loya Jirga of one thousand three hundred and eighty one (HS), (2002), with due respect to provisions of this Constitution, shall be preserved during his lifetime.

\section{Article One Hundred Fifty-Nine}

The interim period between the adoption of the Constitution and the inauguration of the National Assembly shall be considered the transition period.

The Islamic Transitional Government of Afghanistan, during the transitional period, shall perform the following duties:

1. Issuing legislative decrees related to elections of the President, National Assembly as well as local councils within six months;

2. Issuing decrees regarding the organization and authority of courts as well as the commencement of work on fundamental organizations law in less than one year; 3. Establishing the Independent Elections Commission;

4. Completing necessary reforms to better regulate executive as well as judicial affairs;

5. Adopting necessary measures to prepare the ground for implementing provisions of the Constitution.

\section{Article One Hundred Sixty}

The first President-Elect shall, according to provisions of this Constitution, commence work thirty days after election results are declared. Multilateral efforts shall be made to hold presidential as well as National Assembly elections concurrently and simultaneously. Pending the establishment of the National Assembly, its powers, enshrined in this Constitution, shall be submitted to the government, and the interim Supreme Court shall be established by presidential decree.

Article One Hundred Sixty-One

Immediately after inauguration, the National Assembly shall exercise its powers in accordance with the provisions of this Constitution. After inauguration of the first session of the National Assembly, within thirty days, the government as well as the Supreme Court shall be inaugurated in accordance with the provisions of the Constitution. The President of the Islamic Transitional Government of Afghanistan shall perform his duties until the inauguration of the PresidentElect. The executive and judicial organs of the state, in accordance with Clause Four of Article One Hundred Fifty-Nine of this Constitution, shall continue with their duties pending the formation of the government as well as the Supreme Court. Legislative decrees enforced from the beginning of the interim period shall be referred to the first session of the National Assembly. These decrees shall be enforceable unless annulled by the National Assembly. 
Article One Hundred Sixty-Two

This Constitution shall be enforced from the date of approval by the Loya Jirga, and endorsed and proclaimed by the President of the Islamic Transitional Government of Afghanistan. Upon the enforcement of this Constitution, laws and legislative decrees contrary to its provisions shall be invalid. 


\section{BONN AGREEMENT}

Formally know as the:

\section{AGREEMENT ON PROVISIONAL ARRANGEMENTS IN AFGHANISTAN PENDING THE RE-ESTABLISHMENT OF PERMANENT GOVERNMENT INSTITUTIONS}

The participants in the UN Talks on Afghanistan,

In the presence of the Special Representative of the Secretary-General for Afghanistan,

Determined to end the tragic conflict in Afghanistan and promote national reconciliation, lasting peace, stability and respect for human rights in the country,

Reaffirming the independence, national sovereignty and territorial integrity of Afghanistan,

Acknowledging the right of the people of Afghanistan to freely determine their own political future in accordance with the principles of Islam, democracy, pluralism and social justice,

Expressing their appreciation to the Afghan mujahidin who, over the years, have defended the independence, territorial integrity and national unity of the country and have played a major role in the struggle against terrorism and oppression, and whose sacrifice has now made them both heroes of jihad and champions of peace, stability and reconstruction of their beloved homeland, Afghanistan,

Aware that the unstable situation in Afghanistan requires the implementation of emergency interim arrangements and expressing their deep appreciation to His Excellency Professor Burhanuddin Rabbani for his readiness to transfer power to an interim authority which is to be established pursuant to this agreement,

Recognizing the need to ensure broad representation in these interim arrangements of all segments of the Afghan population, including groups that have not been adequately represented at the UN Talks on Afghanistan,

Noting that these interim arrangements are intended as a first step toward the establishment of a broad-based, gender-sensitive, multi-ethnic and fully representative government, and are not intended to remain in place beyond the specified period of time,

Recognizing that some time may be required for a new Afghan security force to be fully constituted and functional and that therefore other security provisions detailed in Annex I to this agreement must meanwhile be put in place,

Considering that the United Nations, as the internationally recognized impartial institution, has a particularly important role to play, detailed in Annex II to this agreement, in the period prior to the establishment of permanent institutions in Afghanistan, 
Have agreed as follows:

\section{THE INTERIM AUTHORITY}

\section{General provisions}

1) An Interim Authority shall be established upon the official transfer of power on 22 December 2001.

2) The Interim Authority shall consist of an Interim Administration presided over by a Chairman, a Special Independent Commission for the Convening of the Emergency Loya Jirga, and a Supreme Court of Afghanistan, as well as such other courts as may be established by the Interim Administration. The composition, functions and governing procedures for the Interim Administration and the Special Independent Commission are set forth in this agreement.

3) Upon the official transfer of power, the Interim Authority shall be the repository of Afghan sovereignty, with immediate effect. As such, it shall, throughout the interim period, represent Afghanistan in its external relations and shall occupy the seat of Afghanistan at the United Nations and in its specialized agencies, as well as in other international institutions and conferences.

4) An Emergency Loya Jirga shall be convened within six months of the establishment of the Interim Authority. The Emergency Loya Jirga will be opened by His Majesty Mohammed Zaher, the former King of Afghanistan. The Emergency Loya Jirga shall decide on a Transitional Authority, including a broad-based transitional administration, to lead Afghanistan until such time as a fully representative government can be elected through free and fair elections to be held no later than two years from the date of the convening of the Emergency Loya Jirga.

5) The Interim Authority shall cease to exist once the Transitional Authority has been established by the Emergency Loya Jirga.

6) A Constitutional Loya Jirga shall be convened within eighteen months of the establishment of the Transitional Authority, in order to adopt a new constitution for Afghanistan. In order to assist the Constitutional Loya Jirga prepare the proposed Constitution, the Transitional Administration shall, within two months of its commencement and with the assistance of the United Nations, establish a Constitutional Commission.

\section{Legal framework and judicial system}

1) The following legal framework shall be applicable on an interim basis until the adoption of the new Constitution referred to above:

i) The Constitution of 1964, a/ to the extent that its provisions are not inconsistent with those contained in this agreement, and $\mathrm{b} /$ with the exception of those provisions relating to the 
monarchy and to the executive and legislative bodies provided in the Constitution; and ii) existing laws and regulations, to the extent that they are not inconsistent with this agreement or with international legal obligations to which Afghanistan is a party, or with those applicable provisions contained in the Constitution of 1964, provided that the Interim Authority shall have the power to repeal or amend those laws and regulations.

2) The judicial power of Afghanistan shall be independent and shall be vested in a Supreme Court of Afghanistan, and such other courts as may be established by the Interim Administration. The Interim Administration shall establish, with the assistance of the United Nations, a Judicial Commission to rebuild the domestic justice system in accordance with Islamic principles, international standards, the rule of law and Afghan legal traditions.

\section{Interim Administration}

\section{A. Composition}

1) The Interim Administration shall be composed of a Chairman, five Vice Chairmen and 24 other members. Each member, except the Chairman, may head a department of the Interim Administration.

2) The participants in the UN Talks on Afghanistan have invited His Majesty Mohammed Zaher, the former King of Afghanistan, to chair the Interim Administration. His Majesty has indicated that he would prefer that a suitable candidate acceptable to the participants be selected as the Chair of the Interim Administration.

3) The Chairman, the Vice Chairmen and other members of the Interim Administration have been selected by the participants in the UN Talks on Afghanistan, as listed in Annex IV to this agreement. The selection has been made on the basis of professional competence and personal integrity from lists submitted by the participants in the UN Talks, with due regard to the ethnic, geographic and religious composition of Afghanistan and to the importance of the participation of women.

4) No person serving as a member of the Interim Administration may simultaneously hold membership of the Special Independent Commission for the Convening of the Emergency Loya Jirga.

\section{B. Procedures}

1) The Chairman of the Interim Administration, or in his/her absence one of the Vice Chairmen, shall call and chair meetings and propose the agenda for these meetings.

2) The Interim Administration shall endeavour to reach its decisions by consensus. In order for any decision to be taken, at least 22 members must be in attendance. If a vote becomes necessary, decisions shall be taken by a majority of the members present and voting, unless 
otherwise stipulated in this agreement. The Chairman shall cast the deciding vote in the event that the members are divided equally.

\section{Functions}

1) The Interim Administration shall be entrusted with the day-to-day conduct of the affairs of state, and shall have the right to issue decrees for the peace, order and good government of Afghanistan.

2) The Chairman of the Interim Administration or, in his/her absence, one of the Vice Chairmen, shall represent the Interim Administration as appropriate.

3) Those members responsible for the administration of individual departments shall also be responsible for implementing the policies of the Interim Administration within their areas of responsibility.

4) Upon the official transfer of power, the Interim Administration shall have full jurisdiction over the printing and delivery of the national currency and special drawing rights from international financial institutions. The Interim Administration shall establish, with the assistance of the United Nations, a Central Bank of Afghanistan that will regulate the money supply of the country through transparent and accountable procedures.

5) The Interim Administration shall establish, with the assistance of the United Nations, an independent Civil Service Commission to provide the Interim Authority and the future Transitional Authority with shortlists of candidates for key posts in the administrative departments, as well as those of governors and uluswals, in order to ensure their competence and integrity.

6) The Interim Administration shall, with the assistance of the United Nations, establish an independent Human Rights Commission, whose responsibilities will include human rights monitoring, investigation of violations of human rights, and development of domestic human rights institutions. The Interim Administration may, with the assistance of the United Nations, also establish any other commissions to review matters not covered in this agreement.

7) The members of the Interim Administration shall abide by a Code of Conduct elaborated in accordance with international standards.

8) Failure by a member of the Interim Administration to abide by the provisions of the Code of Conduct shall lead to his/her suspension from that body. The decision to suspend a member shall be taken by a two-thirds majority of the membership of the Interim Administration on the proposal of its Chairman or any of its Vice Chairmen.

9) The functions and powers of members of the Interim Administration will be further elaborated, as appropriate, with the assistance of the United Nations. 
IV. The Special Independent Commission for the Convening of the Emergency Loya Jirga

1) The Special Independent Commission for the Convening of the Emergency Loya Jirga shall be established within one month of the establishment of the Interim Authority. The Special Independent Commission will consist of twenty-one members, a number of whom should have expertise in constitutional or customary law. The members will be selected from lists of candidates submitted by participants in the UN Talks on Afghanistan as well as Afghan professional and civil society groups. The United Nations will assist with the establishment and functioning of the commission and of a substantial secretariat.

2) The Special Independent Commission will have the final authority for determining the procedures for and the number of people who will participate in the Emergency Loya Jirga. The Special Independent Commission will draft rules and procedures specifying (i) criteria for allocation of seats to the settled and nomadic population residing in the country; (ii) criteria for allocation of seats to the Afghan refugees living in Iran, Pakistan, and elsewhere, and Afghans from the diaspora; (iii) criteria for inclusion of civil society organizations and prominent individuals, including Islamic scholars, intellectuals, and traders, both within the country and in the diaspora. The Special Independent Commission will ensure that due attention is paid to the representation in the Emergency Loya Jirga of a significant number of women as well as all other segments of the Afghan population.

3) The Special Independent Commission will publish and disseminate the rules and procedures for the convening of the Emergency Loya Jirga at least ten weeks before the Emergency Loya Jirga convenes, together with the date for its commencement and its suggested location and duration.

4) The Special Independent Commission will adopt and implement procedures for monitoring the process of nomination of individuals to the Emergency Loya Jirga to ensure that the process of indirect election or selection is transparent and fair. To pre-empt conflict over nominations, the Special Independent Commission will specify mechanisms for filing of grievances and rules for arbitration of disputes.

5) The Emergency Loya Jirga will elect a Head of the State for the Transitional Administration and will approve proposals for the structure and key personnel of the Transitional Administration.

\section{Final provisions}

1) Upon the official transfer of power, all mujahidin, Afghan armed forces and armed groups in the country shall come under the command and control of the Interim Authority, and be reorganized according to the requirements of the new Afghan security and armed forces. 
2) The Interim Authority and the Emergency Loya Jirga shall act in accordance with basic principles and provisions contained in international instruments on human rights and international humanitarian law to which Afghanistan is a party.

3) The Interim Authority shall cooperate with the international community in the fight against terrorism, drugs and organized crime. It shall commit itself to respect international law and maintain peaceful and friendly relations with neighbouring countries and the rest of the international community.

4) The Interim Authority and the Special Independent Commission for the Convening of the Emergency Loya Jirga will ensure the participation of women as well as the equitable representation of all ethnic and religious communities in the Interim Administration and the Emergency Loya Jirga.

5) All actions taken by the Interim Authority shall be consistent with Security Council resolution 1378 (14 November 2001) and other relevant Security Council resolutions relating to Afghanistan.

6) Rules of procedure for the organs established under the Interim Authority will be elaborated as appropriate with the assistance of the United Nations.

This agreement, of which the annexes constitute an integral part, done in Bonn on this 5 th day of December 2001 in the English language, shall be the authentic text, in a single copy which shall remain deposited in the archives of the United Nations. Official texts shall be provided in Dari and Pashto, and such other languages as the Special Representative of the Secretary-General may designate. The Special Representative of the Secretary-General shall send certified copies in English, Dari and Pashto to each of the participants.

\section{For the participants in the UN Talks on Afghanistan:}

Ms. Amena Afzali

Mr. S. Hussain Anwari

Mr. Hedayat Amin Arsala

Mr. Sayed Hamed Gailani

Mr. Rahmatullah Musa Ghazi

Eng. Abdul Hakim

Mr. Houmayoun Jareer

Mr. Abbas Karimi 
Mr. Mustafa Kazimi

Dr. Azizullah Ludin

Mr. Ahmad Wali Massoud

Mr. Hafizullah Asif Mohseni

Prof. Mohammad Ishaq Nadiri

Mr. Mohammad Natiqi

Mr. Yunus Qanooni

Dr. Zalmai Rassoul

Mr. H. Mirwais Sadeq

Dr. Mohammad Jalil Shams

Prof. Abdul Sattar Sirat

Mr. Humayun Tandar

Mrs. Sima Wali

General Abdul Rahim Wardak

Mr. Pacha Khan Zadran

\section{Witnessed for the United Nations by:}

Mr. Lakhdar Brahimi

Special Representative of the Secretary-General for Afghanistan 


\section{ANNEX I \\ INTERNATIONAL SECURITY FORCE}

1. The participants in the UN Talks on Afghanistan recognize that the responsibility for providing security and law and order throughout the country resides with the Afghans themselves. To this end, they pledge their commitment to do all within their means and influence to ensure such security, including for all United Nations and other personnel of international governmental and non-governmental organizations deployed in Afghanistan.

2. With this objective in mind, the participants request the assistance of the international community in helping the new Afghan authorities in the establishment and training of new Afghan security and armed forces.

3. Conscious that some time may be required for the new Afghan security and armed forces to be fully constituted and functioning, the participants in the UN Talks on Afghanistan request the United Nations Security Council to consider authorizing the early deployment to Afghanistan of a United Nations mandated force. This force will assist in the maintenance of security for Kabul and its surrounding areas. Such a force could, as appropriate, be progressively expanded to other urban centres and other areas.

4. The participants in the UN Talks on Afghanistan pledge to withdraw all military units from Kabul and other urban centers or other areas in which the UN mandated force is deployed. It would also be desirable if such a force were to assist in the rehabilitation of Afghanistan's infrastructure.

\section{ANNEX II ROLE OF THE UNITED NATIONS DURING THE INTERIM PERIOD}

1. The Special Representative of the Secretary-General will be responsible for all aspects of the United Nations' work in Afghanistan.

2. The Special Representative shall monitor and assist in the implementation of all aspects of this agreement.

3. The United Nations shall advise the Interim Authority in establishing a politically neutral environment conducive to the holding of the Emergency Loya Jirga in free and fair conditions. The United Nations shall pay special attention to the conduct of those bodies and administrative 
departments which could directly influence the convening and outcome of the Emergency Loya Jirga.

4. The Special Representative of the Secretary-General or his/her delegate may be invited to attend the meetings of the Interim Administration and the Special Independent Commission on the Convening of the Emergency Loya Jirga.

5. If for whatever reason the Interim Administration or the Special Independent Commission were actively prevented from meeting or unable to reach a decision on a matter related to the convening of the Emergency Loya Jirga, the Special Representative of the Secretary-General shall, taking into account the views expressed in the Interim Administration or in the Special Independent Commission, use his/her good offices with a view to facilitating a resolution to the impasse or a decision.

6. The United Nations shall have the right to investigate human rights violations and, where necessary, recommend corrective action. It will also be responsible for the development and implementation of a programme of human rights education to promote respect for and understanding of human rights.

\section{ANNEX III}

\section{REQUEST TO THE UNITED NATIONS BY THE PARTICIPANTS AT THE UN TALKS ON AFGHANISTAN}

The participants in the UN Talks on Afghanistan hereby

1. Request that the United Nations and the international community take the necessary measures to guarantee the national sovereignty, territorial integrity and unity of Afghanistan as well as the non-interference by foreign countries in Afghanistan's internal affairs;

2. Urge the United Nations, the international community, particularly donor countries and multilateral institutions, to reaffirm, strengthen and implement their commitment to assist with the rehabilitation, recovery and reconstruction of Afghanistan, in coordination with the Interim Authority;

3. Request the United Nations to conduct as soon as possible (i) a registration of voters in advance of the general elections that will be held upon the adoption of the new constitution by the constitutional Loya Jirga and (ii) a census of the population of Afghanistan.

4. Urge the United Nations and the international community, in recognition of the heroic role played by the mujahidin in protecting the independence of Afghanistan and the dignity of its people, to take the necessary measures, in coordination with the Interim Authority, to assist in the reintegration of the mujahidin into the new Afghan security and armed forces; 
5. Invite the United Nations and the international community to create a fund to assist the families and other dependents of martyrs and victims of the war, as well as the war disabled;

6. Strongly urge that the United Nations, the international community and regional organizations cooperate with the Interim Authority to combat international terrorism, cultivation and trafficking of illicit drugs and provide Afghan farmers with financial, material and technical resources for alternative crop production.

\section{ANNEX IV}

\section{COMPOSITION OF THE INTERIM ADMINISTRATION}

\section{Chairman:}

Hamid Karzai

\section{Vice Chairmen:}

Vice-Chair \& Women's Affairs:

Dr. Sima Samar

Vice-Chair \& Defence:

Muhammad Qassem Fahim

Vice-Chair \& Planning:

Haji Muhammad Mohaqqeq

Vice-Chair \& Water and Electricity:

Shaker Kargar

Vice-Chair \& Finance:

Hedayat Amin Arsala

\section{Members:}

Department of Foreign Affairs:

Dr. Abdullah Abdullah

Department of the Interior:

Muhammad Yunus Qanooni

Department of Commerce:

Seyyed Mustafa Kazemi

Department of Mines \& Industries:

Muhammad Alem Razm

Department of Small Industries:

Aref Noorzai

Department of Information \& Culture:

Dr. Raheen Makhdoom

Department of Communication:

Ing. Abdul Rahim

Department of Labour \& Social Affairs:

Mir Wais Sadeq 
Department of Hajj \& Auqaf:

Department of Martyrs \& Disabled:

Department of Education:

Department of Higher Education:

Department of Public Health:

Department of Public Works:

Department of Rural Development:

Department of Urban Development:

Department of Reconstruction:

Department of Transport:

Department for the Return of Refugees:

Department of Agriculture:

Department of Irrigation:

Department of Justice:

Department of Air Transport \& Tourism:

Department of Border Affairs:
Mohammad Hanif Hanif Balkhi

Abdullah Wardak

Abdul Rassoul Amin

Dr. Sharif Faez

Dr. Suhaila Seddiqi

Abdul Khaliq Fazal

Abdul Malik Anwar

Haji Abdul Qadir

Amin Farhang

Sultan Hamid Sultan

Enayatullah Nazeri

Seyyed Hussein Anwari

Haji Mangal Hussein

Abdul Rahim Karimi

Abdul Rahman

Amanullah Zadran 


\section{LAW ON ORGANIZATION AND JURISDICTION OF COURTS OF THE ISLAMIC REPUBLIC OF AFGHANISTAN}

\section{CHAPTER 1: GENERAL PROVISIONS}

Article 1:

Objective:

This law has been enacted pursuant to the provisions of Articles 116 and 123 of the Constitution for the purpose of managing the affairs related to the organization of the judiciary, duties and powers of the Supreme Court, primary and appeal courts and judges of the Islamic Republic of Afghanistan.

Article 2:

Independence:

The Judiciary shall be the independent pillar of the state and composed of Supreme Court, Courts of Appeal and Primary Courts. Traveling courts may be established when needed, on recommendation by the Supreme Court and approval of the President.

Article 3:

Dispute Resolution:

The Judiciary may resolve disputes between and among individuals, legal entities including the state in accordance with law.

Article 4:

Jurisdiction:

No law under any circumstances may take a case out of the jurisdiction of judiciary and submit it to a different authority.

This article may not hamper the formation of specialized courts and military courts set forth in Articles 69, 78, and 127 of the Constitution.

Article 5:

Appealing:

The parties to the case may appeal against decisions issued by the lower courts in accordance with law. The final decisions of the courts shall be considered exception to this provision.

Article 6:

Resolution Methodology:

(1) The cases shall be resolved in courts taking into consideration the quality and nature of the case in two stages, primary and appeal.

(2) The Supreme Court shall deal with the referred cases of courts of appeal only in terms of accurate application of law (to see if any provision of law is breached or accurately applied), unless it has been authorized by law to resolve a case taking into consideration the quality and nature of the case.

(3) Cases in courts shall be handled as follows:

1 - At the primary stage, with participation of three judges. Except less than three judges may decide a case when they are not available. 
2 - $\quad$ At the appeal stage, three judges shall decide any case.

3 - At the cessation stage, shall take place by two or more persons.

Article 7:

Source of Decisions:

The courts shall resolve cases in accordance with the constitution and other laws of the Islamic Republic of Afghanistan. If there is no clear legal provision for the case, the case shall be handled in accordance with Articles 130 and 131 of the Constitution.

Article 8:

Open Trials:

Trials in the Afghanistan courts shall happen in open procedure in which everybody may attend, subject to law. The court may convene the trials in a close procedure only if they are legally required or that it is deemed necessary. Making notice of the final decision shall always be open to public.

Article 9:

Legal Citation:

The courts shall be duty bound to rely on the reasons, grounds and legal provisions for a decision to issue.

Article 10:

Enforceability of Decisions:

The courts final decisions shall be enforceable unless it is about a death sentence, which requires approval of the President.

Article 11:

Right to Defense Attorney:

Each person shall be entitled to a defense attorney immediately after the person's arrest to remove the accusation charged against. In criminal cases, there shall be assigned defense attorneys for the destitute in accordance with the relevant legislation.

Article 12:

Translators / Interpreters:

If the party does not speak the official language that trial is held in, a translator / interpreter may help the person understand articles and details of the case and the person shall have the right to speak in the person's native language before the court.

Article 13:

Nonrefusal of Ruling:

The court may not refuse to issue an order in any case that is under its proceeding. A case may leave the court only after decision is taken.

Article 14:

Independence in Issuing Decisions: 
Courts shall be independent but subject to law only when issuing orders. Resolving a case and issuing an order by the courts shall be based on the principle of the parties' mutual equality before the law and the court and obeying justice and impartiality.

Article 15:

Prohibition on Party Membership:

Judges may not hold membership in any political party while working as judge.

\section{CHAPTER 2: ORGANIZATION, STRUCTURE, AND JURISDICTION OF THE SUPREME COURT}

Article 16:

The Supreme Court:

The Supreme Court constitutes the highest authority of the judiciary of the Islamic Republic of Afghanistan.

Article 17:

Organization of the Supreme Court:

The Supreme Court shall be composed of 9 persons appointed by the President in agreement with Wolesi Jirga (House of the People) in accordance with Articles 117 and 118 of the Constitution. The president shall appoint one of the members as the Chief [Justice] of the Supreme Court.

Article 18:

Supreme Court Dewans:

(1) The Supreme Court shall consist of the following Dewans:

1 - General Criminal Dewan.

2 - Public Security Dewan.

3 - $\quad$ Civil and Public Rights Dewan.

4 - Commercial Dewan.

(2) Each Dewan set forth in paragraph (1) of this article shall be headed by a member of the Supreme Court as selected on rotation basis by the Chief Justice for the period of 1 year.

Article 19:

Powers of Heads of Dewans:

Each head of the Supreme Court Dewans shall have the following powers and duties:

1 - Leading relevant Dewan's activities.

2 - Holding and presiding over relevant Dewan's sessions.

3 - Arranging affairs, coordinating judicial experiences of the Dewans, and submission of report to the Supreme Court.

Article 20:

Judicial Advisors:

The Supreme Court shall have judicial advisors and their total number may not be more than 36 persons. 
Article 21:

Appointment of Judicial Advisors:

Judicial advisors of the Supreme Court shall be selected from among the judges who have required qualification, sufficiency and full competency, and at least have 10 years practical judicial work experience.

Assignment of judicial advisors to the Dewans shall be the authority of chief justice.

Article 22:

Duties of Advisors:

The judicial advisors shall analyze and study the cases filed and provide a report to the judicial meeting for decision to be made.

Article 23:

General Administration Office of the Judiciary:

(1) The judiciary shall have General Directorate of Administration to manage issues related to judicial and administration affairs.

(2) Head of the Administration Office of the Judiciary shall be appointed on the recommendation of the chief justice and approval of the President. Head of the Administration Office of the Judiciary shall at the same time be both the secretary and spokesman for the Supreme Court and shall have the following qualities:

1 - Must not be younger than 30 [years old] upon appointment.

2 - Have higher education and have enough administrative experience.

3 - Have good character and moral and be well known.

4 - Not be convicted with anti-human crime, felony, or deprived of civil rights.

(7) The Supreme Court shall have professional and administrative branches, which operate under the framework of General Administration Office of the Judiciary. Organization and structure of the professional and administrative branches shall be regulated by special regulation. (8) General Administrative Office may create, if required, other branches after the consent of Supreme Court and approval of the President.

Article 24:

Judicial Powers and Duties of the Supreme Court:

The Supreme Court shall have the following jurisdictions and duties within the scope of interpretation of laws and judicial issues:

1 - Assessment on conformity of laws, decrees, legal documents, international contracts and conventions with the Constitution and their interpretation based on the government or courts demand in accordance with law.

2 - Propose for draft law on regulating the judicial affairs to the national assembly through government.

3 - Revising the rulings of courts due to presence of new reasons based on complaint by the Attorney General's Office (AGO) or by party to the claim according to the mentioned provisions and arrangement in the law.

4 - resolving Courts' Conflict of Jurisdiction and submitting jurisdiction of resolving a case from one court to the other based on proposal by the Attorney General's Office or party to the claim when reasonable grounds arise. 
5 - $\quad$ Studying reasons and making decision on extraditing criminals to foreign states in accordance with law.

6 - Studying reasons of a charge made and making decision on submitting the Afghan citizen to the foreign state in the light of Article 28 of the Constitution.

7 - $\quad$ Ensuring uniformity in judicial treatment.

8 - $\quad$ Taking measures on criminal and disciplinary offences by judges.

9 - Evaluating the courts inquiries on judicial issues and providing responses accordingly.

Article 25:

Convening Sessions:

(1) The Supreme Court shall convene its regular sessions once in 15 days.

(2) The Supreme Court's extraordinary sessions shall be convened on a request by the chief

justice, proposal by the Attorney General's Office or on the demand by one-third of its members.

(3) The required number to attend the Supreme Court meetings shall be completed by two-

thirds of its members. The decisions shall be made upon by majority vote unless this law mentions different.

(4) The Attorney General or, in case absent, the Attorney General's deputy to whom the Attorney General's jurisdiction was transferred, shall attend the Supreme Court meetings on criminal issues.

(5) On the issues mentioned in clauses 1, 2, 3, 4, 5, 6, and 8 of Article 24 of this law, decision may be made by two-thirds majority of all the members of the Supreme Court.

Article 26:

Overturning Lower Court Decisions:

(1) If a Supreme Court Dewan determines that the lower court ruling was contrary to the law, fails to conform or interpret or contrary to the Articles 130 and 131 of the Constitution, it shall overturn the ruling and remand it to the lower court for issuance of ruling. The Supreme Court Dewan may overturn a ruling which it observes as contrary to the law even if the breach is not mentioned in the appeal.

(2) If the failure in consistency or interpreting the law does not substantially affect the ruling and the ruling is accurate and agrees to the law, the relevant Dewan may confirm it.

Article 27:

Remand for Invalidity:

(1) If the Supreme Court Dewan overturns the appealable ruling due to invalidity in the order or invalidity in the basic procedures of the order, it shall remand the case to the relevant court by mentioning the reasons for a decision. In the event the case is remanded to the first court, majority of the judges who consider the case shall not have decided the case before the appeal.

(2) If there is a second appeal against the decision of the court for which the case was previously remanded and the appeal is based on the previous reasons and grounds and the referred court has issued the previous ruling (overturned by supreme court) with the same (first) reasons, the Supreme Court shall take the issue into further study. If the appealed case is overturned by the majority vote of the Court for related cases, the court for which the remanded ruling was referred shall resolve and issue ruling and in this case the referred court shall be duty bound to respect the instructed resolution by the Supreme Court and their ruling at this stage shall be final. 
Article 28:

Enforceability of orders and Rulings (Qarar):

The orders and Qarars by the higher court shall be enforceable on the lower courts on newly resolving of cases.

Article 29:

Administrative Duties and jurisdictions of Supreme Court:

(1) The Supreme Court shall have the following duties and jurisdictions in its relevant administration affairs:

1 - To prepare the budget for the judiciary in consultation with the government

2 - To lead and control the administrative activities of courts of Islamic Republic of Afghanistan

3 - To approve rules and regulations to regulate matters concerning judicial and administration of courts.

4 - $\quad$ To evaluate the results of judicial scrutiny and studies and taking measures to remove defects and coordinate courts' procedures.

5 - To propose on the appointment of judges and judicial advisors to the president's office according to provisions of this law.

6 - To propose on the appointment, transfer, upgrading, extension of the appointments' duration and retirement of judges according to the provisions of this law.

7 - $\quad$ To propose on the establishment of courts and legal document registration directorates, and their specification of judicial and administration jurisdiction to the president's office.

8 - To implement the budget of the judiciary.

9 - $\quad$ To provide necessary facilities for the activities of the courts.

10 - To hold judicial practice courses.

11 - To take appropriate measures for enhancing the knowledge and experience of judges.

12 - To monitor the performance and activities of employees of the judicial authority.

13 - To prepare annual statistic report of all courts judicial activities.

14 - Other duties and jurisdictions which are delegated to Supreme Court according to this law and all other laws.

(2) The powers set forth in clause one of this article shall be implemented through the General Administration Office of the Judiciary.

Article 30:

Powers of the Head of Supreme Court (Chief Justice):

The Chief Justice shall represent the Judicial Authority of Islamic Republic of Afghanistan and shall have the following jurisdiction and duties:

1 - To lead the judicial and administrative activities of the Supreme Court.

2 - $\quad$ To preside over the meetings of the Supreme Court.

3 - To chair the judicial sessions of the relevant Dewans of the Supreme Court as needed.

4 - $\quad$ To issue orders on the inspection of court activities.

5 - To issue orders on resolving cases resulting from crimes and judicial and administrative violation by judges.

6 - To monitor the implementation of courts final decisions.

7 - $\quad$ To monitor and control appropriate expenditure of the judicial budget. 
8 - To delegate all or some of his/her powers to one of the members of the Supreme Court when sick, on leave, absence and other reasons.

9 - $\quad$ To monitor activities the General Administration Office of the judiciary.

10 - To provide reports on judicial and administrative activities of the judiciary to the president.

11 - To propose on pardoning, mitigation of imprisonment and other punishments of judges to the President's office.

12 - Other assigned powers in accordance with the provisions of this and other laws.

\section{CHAPTER 3: ORGANIZATION, STRUCTURE, AND POWERS OF THE COURTS OF APPEALS}

Article 31:

Organization of the Courts of Appeals:

(1) Courts of Appeals shall be established in all the provinces in accordance with this law.

(2) The Courts of Appeals shall be composed of chief of the court, heads of Dewans, and

other judicial members. Head of the Courts of Appeal shall be selected from among the judges who have enough qualification, experience, and competency.

(3) Head of the General Criminal Dewan shall be deputy head of court of appeals.

Article 32:

Structure of Dewans of Courts of Appeals:

(1) The Courts of Appeals shall contain the following Dewans:

1 - General Criminal Dewan.

2 - Public Security Dewan.

3 - $\quad$ Civil and Family Dewan.

4 - $\quad$ Public Rights Dewan.

5 - Commercial Dewan.

6 - Juveniles Dewan.

(2) There shall not be more than 6 judicial members within each Dewan of the Court of Appeals.

(3) General Criminal Dewan of Court of Appeals shall resolve traffic-originated cases.

(4) The Supreme Court may as needed establish other Dewans within the structure of the Court of Appeals with the approval of the President.

Article 33:

Follow-Up on Decisions and Rulings (Qarar):

(1) The Court of Appeals shall oversee the rulings and decisions of the lower courts, in situations according to the provisions of the related laws.

(2) The Court of Appeals while resolving cases set forth in paragraph (1) of this article shall reconsider the whole legal process. It may correct, overturn, amend, confirm or repeal the rulings and decisions of the lower courts.

Article 34:

Resolving Conflicts of Judicial Jurisdiction: 
(1) Whenever there is a conflict over jurisdiction of resolving a criminal case between two courts within jurisdiction of a single Court of Appeals, an authorized board made up of the head of the Court of Appeals as head and the heads of Dewans shall decide on which court has the jurisdiction to decide a case.

(2) Deciding about the future of the accused that is in custody as mentioned in paragraph (1) of this article shall only be the jurisdiction of the Court of Appeals.

Article 35:

Finality of Decisions and Rulings:

The issued decisions and rulings of the Court of Appeals shall be final in all relevant cases.

Article 36:

Duties and Powers of Head of the Court of Appeals:

The head of the Court of Appeals has the following responsibilities and powers:

$1-\quad$ To lead and organize activities of the respective Dewans.

2 - $\quad$ To preside over the judicial meetings of the Dewans, when necessary.

3 - $\quad$ To assign member of one Dewan to another on temporary basis.

4 - To assign one of the judges of the court of appeals to the primary courts when necessary.

5 - $\quad$ To delegate the authority of resolving a certain case from one Dewan to another, when necessary.

6 - To coordinate judicial experiences of respective Dewans.

7 - To prepare activity reports of Dewans and courts and to deliver the reports to the Supreme Court.

Article 37:

Presiding Over Meetings:

Heads of the Dewans of the Court of Appeals shall have the responsibility of leading the respective Dewans as well as presiding over meetings. In case head of the court of appeals presides over judicial meeting, the head of respective Dewan shall then be considered as member.

Article 38:

Responsibility:

The head of each Court of Appeals and each judge and head of each Dewan shall be responsible for deciding cases in a timely manner according to the law, correct application of the law, and for explaining the ground for their decision.

Article 39:

Branches of the Court of Appeals:

Each Court of Appeals and relevant Dewans shall have administrative branches and personnel whose activities and manner of performance shall be specified through separate regulations.

\section{CHAPTER 4: ORGANIZATION, STRUCTURE, AND JURISDICTION OF PRIMARY COURTS}

Article 40: 
Organization:

(1) In the jurisdictional area of each Court of Appeals, there are these primary courts:

1 - Central Provincial Primary Court.

$2-\quad$ Juveniles Court.

3 - $\quad$ Commercial Primary Court.

4 - $\quad$ District Primary Court.

5 - $\quad$ Family Issues Primary Court.

(2) The Supreme Court may establish more courts in the centers of provinces when required after approval of the president.

Article 41:

Primary Court Structure:

(1) A central primary court shall be comprised of the following Dewans:

1 - General Criminal Dewan.

2 - Civil Dewan.

3 - Public Rights Dewan.

4 - Public Security Dewan.

5 - $\quad$ Traffic Criminal Dewan.

(2) The Dewans of central primary court shall have one head and no more than 4 members.

Article 42:

Resolving Cases by Dewans of Primary Courts:

Central provincial primary courts shall have the relevant Dewans to resolve cases in primary level in accordance with law:

1 - Resolving general criminal cases by General Criminal Dewan.

2 - $\quad$ Resolving civil disputes between natural persons by Civil Dewan.

3 - Resolving civil disputes between natural and legal individuals / entities or among legal entities by Public Rights Dewan.

4 - $\quad$ Resolving criminal cases of public security and interest, drug trafficking and other crimes by Public Security Dewan in accordance with law.

5 - $\quad$ Resolving traffic criminal cases by Traffic-Related Crimes Dewan.

Article 43:

Leading Court and Dewans:

(1) There shall be a head for the central provincial primary court to lead and manage the judicial and administrative activities of the Dewans and shall attend their meetings when required.

(2) Heads of the primary court Dewans shall lead meetings of Dewans. In case head of the primary court presides over judicial meeting of the Dewan, head of the respective Dewan shall thus be considered as member.

(3) Head of the General Criminal Dewan shall at the same time be deputy head of the central primary court.

Article 44:

Juvenile Court:

(1) There shall be established a juvenile primary court in the center of every province. 
(2) The juvenile primary court shall be made up of a head and four members.

In case the head is absent due to any reason, the head's powers and duties shall be transferred to one of the judicially experienced judges.

(3) The method to resolve juveniles' offences shall be determined by a special regulation.

Article 45:

Commercial Primary Court:

(1) A commercial court shall be established in center of every province. This court shall have a chief and 4 other members.

(2) In provinces where commercial court is not available, dealing with commercial cases is the jurisdiction of the civil Dewan of the provincial central primary court.

Article 46:

Resolving Special Cases:

Based on the case, the commercial, public rights and public security cases within the judicial jurisdiction of a Court of Appeals shall be initiated in the commercial court and in the relevant Dewans of the provincial central primary court.

Article 47:

District Primary Court Structure:

(1) The District Primary Court shall consist of a chief and two members. In the areas where there are no members available, the cases shall be decided by fewer than three.

(2) The Chief of the District Primary Court shall lead the court. In the Chief's absence, the responsibilities and powers shall be transferred to the most judicially experienced judge on the court.

Article 48:

District Primary Court Jurisdiction:

District Primary courts shall deal in primary stage with all ordinary criminal, civil, and family cases which are legally presented to them.

Article 49:

Temporary Assignment of Judges:

In case of the article 48 of this law, whenever the court has only one judge or some other situation occurs which requires the assignment of temporary judge; the chief of the Court of Appeals shall have the authority to appoint one of the Court of Appeals judges on temporary service basis.

Article 50:

Establishing Other Necessary Dewans:

(1) The Supreme Court may, as needed, establish other Dewans within the structure of the central provincial primary courts after approval of the President.

(2) The Supreme Court may, as needed, establish other Dewans within the structure of district provincial primary courts after approval of the President.

Article 51: 
Resolving Multiple Crimes:

(1) A criminal shall be tried in the court which has the jurisdiction of resolving cases, in accordance with this and other laws. In case a person commits multiple crimes each of which requires an individual resolving by different courts, the courts dealing with serious crimes shall have jurisdiction of resolving the case first. In case the committed crimes are in one level of gravity, the jurisdiction of resolving the case shall be on the court which has already begun resolving the charges made against the accused.

(2) If a person committed multiple crimes which in terms of jurisdiction is subject to two (specialized and ordinary) courts, each of the courts shall based on the nature of the crime have jurisdiction on the case. In case the committed crime is multiple which is indivisible, the case shall be resolved by the court which has jurisdiction of resolving crimes of higher gravity.

(3) Crime accessories and assistants shall be tried in the court in which the actual criminal is tried.

Article 52:

Responsibility:

The chief of each Primary Court, heads of Dewans, and their judicial members shall be responsible for deciding cases in a timely manner according to the law, correct application of the law, and for explaining the ground for their decision.

Article 53:

Finality of Decisions:

The decisions of the primary courts are absolute and final in the following situations:

1 - When both parties agree upon the issued decision of the court.

2 - When the time for appealing has expired.

3 - When the disputed property is worth up to 100,000 Afghanis.

4 - When the order for a cash fine of 50,000 Afghanis is issued.

5 - $\quad$ Other situations set forth in law.

Article 54:

Administrative Branches:

Primary courts shall have some administrative branches and personnel whose activities and manner of performance shall be specified through separate regulations.

Article 55:

Registration of Documents and Deeds Branches:

(1) In the structure of every Court of Appeals, there shall be established Directorates of Documents and Deeds Registration (DDDR). There shall be a head in charge of a directorate and shall lead and manage the activities of the directorate.

(2) The head and professional members of the Directorate of Documents and Deeds

Registration shall be appointed from among the judges who have judicial authority.

(3) In the districts where there is no such directorate for legal documents registration, the district courts shall have the authority to perform these duties.

(4) Duties and powers of the Directorates of Documents and Deeds Registration shall be regulated through special legislation. 
Article 56:

Registration of Documents and Trademarks:

Registration of commercial documents and trademarks shall be the jurisdiction of the commercial court.

Article 57:

Reporting:

Heads of the primary courts and Directorates of Documents and Deeds Registration shall be duty bound to report on their activities to the court of appeals.

\section{CHAPTER 5: ISSUES CONCERNING JUDGES AND THE EMPLOYEES OF THE JUDICIARY POWER}

Article 58:

Conditions of Being a Judge:

(1) On the recommendation of the Supreme Court and with approval of the President, any qualified person meeting following requirements shall be appointed as a judge:

1 - Upon appointment as judge, hold the citizenship of the Islamic Republic of Afghanistan for at least 10 years.

2 - $\quad$ Not be convicted of any crime or intentional misdemeanor by absolute and final decision of an authorized court.

3 - Hold the bachelor's (B.A.) degree from any faculties of law or Shari'a or above it or holds diploma on Religious Studies from an officially recognized center or equivalent.

4 - $\quad$ Not have any illness or disability which impedes a judge performance of duties.

5 - $\quad$ Has completed the age of 25 [years] upon appointment.

6 - Have passed the practical stage of judicial training course successfully.

(2) The holder of diploma on religious studies from an officially recognized center or equivalent and by meeting the requirements set forth in conditions 1, 2, 4, 5, and 6 of paragraph (1) of this article may be appointed as member in the primary court for a period of first 3 years.

(3) When the number of applicants exceeds the number of vacancies available, the Supreme Court may add more conditions for its admission.

Article 59:

Oath-Taking:

Before occupying the position as judge, a person must swear in front of chief and members of Supreme Court as follows:

"I swear by the name of the Almighty Allah that I perform my duty with full trust and dignity and impartiality, respect and implement provision of Islamic Shari'a, constitution of Afghanistan and other laws of the country, respect confidentiality of my duty, will not commit any crime, violation of other rights, injustice, and bribery directly and indirectly."

This text must be written on a board and after signature of the judge be hung where the judge is employed.

Article 60:

Appointment and Transfer of Judges: 
(1) The appointment, transfer, upgrading, retirement, extension of the appointments' duration, offering approval, and accepting the resignation of judges from Grade 1 and above are made upon the recommendation of the Supreme Court with the approval of the President.

(2) The appointment, transfer, upgrading, retirement, extension of the appointments' duration, offering approval, and accepting the resignation of judges of Grade 2 or lower shall be made upon the recommendation of the head of General Administration Directorate of the judiciary with the approval of Chief [Justice] of the Supreme Court.

Article 61:

Appointment and Transfer of Administrative Staff:

(1) The appointment, transfer, upgrading, retirement, extension of the appointments' duration, offering approval, and accepting the resignation of the administrative staff of the judiciary in HIHG grade and HIGHER grade and contractors of above grade shall be made upon the recommendation of the Chief Justice and approval of the President.

(2) The appointment, transfer, upgrading, retirement, extension of the appointments' duration, offering approval, and accepting the resignation of the administrative staff of grade one and contractors of grade one or lower shall be made upon the recommendation by the head of General Administration Directorate of the judiciary and approval of the Chief Justice.

Article 62:

Retirement of Judges:

(1) A judge shall be retired in the following and may not be reemployed:

1 - Upon completion of 40 years of practical service.

2 - $\quad$ Permanent overall disability and continuous illnesses which hamper job performance.

3 - Up on completion of age of 65 [years].

4 - $\quad$ Other situations mentioned in law.

(2) The Supreme Court when needed may, before forwarding the issue of retirement of a 65year-old judge to the authorities, extend his/her employment for another 10 years if the judge is knowledgeable with academic and professional experience.

The approval for continuation of service shall be renewed every year.

Article 63:

Transfer of Judges:

(1) A judge may not be transferred before 3 years except at the judge's personal request based on reasonable grounds.

(2) The normal transfer of a judge shall occur in the last month of the solar year (Hoot) and shall be valid as of the first month of the next year.

Article 64:

Appreciation Letters:

(1) Appreciation Letters for judges and judicial administration employees shall be distributed on the recommendation of the Chief Justice with approval of, or directly by, the President.

(2) Grades 2 and 3 Appreciation Letters, appraisal letters, and cash benefits for judges and administrative staff of the judiciary shall be offered on recommendation of the General Administration Director and approval of, or directly by, the Chief Justice. 
Article 65:

Implementing Labor and Civil Servants Laws:

(1) Conditions and circumstances of appointment, transfer, upgrading, extending appointment duration, approval and accepting resignation, leave and other merits, privileges and duties of judges and administrative staff of the judiciary not mentioned in this law shall be exercised in accordance with the labor law, civil service law, and other respective legislation.

(2) For the purpose of upgrading judges, in addition to the terms and conditions set forth in paragraph (1) of this article, quality of decisions issued by judges are also considered.

Article 66:

Professional Privileges:

Judges shall be entitled to judicial benefits, issues regarding requirements for judicial grade assignment, upgrading conditions and determining amount of the benefits shall be specified through separate regulation.

Judicial benefits shall be part of the salary.

\section{CHAPTER 6: DISCIPLINE AND PUNISHMENT OF JUDGES}

Article 67:

Detention of Judges:

(1) A judge can not be arrested or detained without the approval of the president except where the evidence against him/her is compelling.

(2) Whenever a judge is accused with a felony crime, the Supreme Court shall resolve the case in accordance with article 133 of the Constitution.

Article 68:

Disciplinary Measures against Judges:

Disciplinary measures for judges shall take place according to particular regulation approved by the Supreme Court.

\section{CHAPTER 7: MISCELLANEOUS PROVISIONS}

Article 69:

Reemployment of Resigned Judges:

A resigned judge upon requesting to continue again within judicial power may be reemployed at the same grade from which the judge resigned.

Situations mentioned in Article 62 of this law shall be considered exception.

Article 70:

Attire for Judges:

Judges while hearing a case must be dressed up in special clothing as set forth in the law.

Article 71:

Identity Card:

Judges shall be issued particular identity (ID) cards whose format and contents shall be prepared and designed by the Supreme Court. 
Article 72:

Stamp:

Supreme Court, Courts of Appeal, Primary Courts, Special Courts, General Administration Directorate of the Judiciary, and Directorates of Documents and Deeds Registration shall all have special stamps.

Article 73:

Judges and Courts Security:

(1) The Ministry of Interior and other security authorities shall be duty bound to ensure security and protection of judges, respective offices, and courthouses.

(2) The agencies mentioned in paragraph (1) of this article shall be duty-bound to implement the final rulings and decisions of the courts.

Article 74:

Salary:

The judicial members of the Supreme Court, judicial advisors, and judges of courts shall be paid enough salary in accordance with the Article 155 of the Constitution. Amount of their salary shall be specified in relevant law.

Article 75:

Registration of Assets:

Judges of the courts and authorities in charge of the Directorate of Documents and Deeds Registration shall be duty-bound to register their movable and immovable property before assuming responsibility.

Article 76:

Special Publication:

(1) The Supreme Court shall have a special publication of its own.

(2) In order to unify judicial methodology, research and follow-up as required necessary by

the Supreme Court, the final decisions of the courts shall be published.

Article 77:

Enforcement Date:

This law shall come into force after approval by the President and should be published in the Official Gazette. By application of this law, the provisions of the Law on the Organization and Jurisdiction of the Courts published in Official Gazette No. 739, dated 11 Hamal 1370 (1991), and other contradicting laws, shall be repealed. 


\section{CIVIL PROCEDURE CODE OF 1990}

In the name of Allah, the Merciful, the Most Merciful

\section{PART ONE:}

\section{CHAPTER ONE:}

\section{GENERAL RULES/PROVISIONS}

\section{ARTICLE ONE}

This Code has been enacted pursuant to the provisions of Article 108 of the Constitution of the Republic of Afghanistan, for the purpose of managing the affairs related to the judgment and manner of proceedings in civil cases in the courts of the Republic of Afghanistan.

\section{ARTICLE TWO}

The principal objectives of this Code are as follows:

1- Observing the equality of the rights of citizens and implementation of the provisions of the laws of the Republic of Afghanistan in civil cases.

2- Management of the due process in judicial proceedings.

3- Determining the limits of rights and duties of the parties to the claim, witnesses and experts.

4- Management of the manner of giving testimony and evaluation of the legal documents, absolute evidence, circumstantial evidence and grounds for judgment.

5- Management of affairs related to appeal, final appeal and review of the decisions and final rulings of the courts.

6- Expediting the proceedings in civil actions.

\section{ARTICLE THREE}

It is within the jurisdiction of the courts in Afghanistan to hear civil actions.

\section{ARTICLE FOUR}

The terms below contained in this Code have the following meanings:

1- Judge: Is the person who issues a judgment. 
2- Acquitted: Is the persons in whose favor a judgment has been issued.

3- Convicted: Is the persons against whom a judgment has been issued.

4- Subject matter of the claim: That which has been the subject matter of the judgment.

5- Manner of Judgment: Is the procedure and manner of issuance of the ruling and decision.

6- Judgment: Is a decision issued by the judge though special words, in absolute and definite manner.

7- Decision: Is the judgment of the judge issued through such words as "I have decided that you ....... in the matter of ........ are bound" and explains his judgment as to whether the subject matter of the claim be dismissed or it should be submitted (for further proceedings); or "I have judged that you must not interfere with the defendant concerning the subject matter of the case."

8- A binding judgment is issued based on the proof of the subject matter of the claim.

9- Judgment of dismissal: is a decision issued in the absence of proof (of the claim).

10- Appeal: Is that in which the appellant (the convicted person) is not satisfied with the judgment of the city, municipal, district or sub-district courts whereupon he/she presents a complaint and objection to the provincial or the district superior court.

11- Final Appeal: Is that in which the appellant is not satisfied with the judgment of the provincial or the district superior court and whereby he/she presents his/her complaint and objection to the Supreme Court.

12- Experts: Are professional persons who have sufficient expertise and experience in specific fields.

\section{CHAPTER TWO: \\ CLAIM}

\section{ARTICLE FIVE}

Claim is demanding a right from another in front of a court of law.

\section{ARTICLE SIX}

The person who demands a right is the plaintiff and the person from whom the right is demanded is defendant.

\section{ARTICLE SEVEN}

The parties to an action must according to the provisions of the law possess legal capacity. 
If there is a lack or absence of legal capacity and there are no provisions providing for guardianship, rules related to executorship and custodianship shall be applicable.

\section{ARTICLE EIGHT}

The subject matter of a claim is the requested object and it involves such rights that the laws of the Republic of Afghanistan have provided for and that they can become the subject matter of claims.

\section{ARTICLE NINE}

1- The legal representative of the government can become a plaintiff or a defendant in the civil cases in which the rights and responsibilities related to the advantage or disadvantage of the government are absolutely or relatively involved.

2- The representative of the government for the purpose of the provisions of clause 1 of this Article is the office of the government cases.

\section{ARTICLE TEN}

The cases in which residents of a village are involved in a common manner, like grazing lands, public way and the like, the presence of some of them as plaintiff or defendant in the court of law is sufficient.

\section{ARTICLE ELEVEN}

1- Claims that are brought for the benefit of or against a deceased or bequest, the presence of one of the heirs as plaintiff or defendant in the proceedings before the court is sufficient.

2- If the claims relate to a moveable bequest, the heir in whose protection the bequest is shall be considered an adversary.

\section{PART TWO:}

\section{CHAPTER ONE: \\ PETITION}

\section{ARTICLE TWELVE}

1- A petition for a civil right is made by an official request letter.

2- A legal request is directly presented to the courts or through legal bureaus to the courts whereupon proceedings are held regarding them.

\section{ARTICLE THIRTEEN}


A legal request contains the following matters:

1- Name, father's name, place, permanent and current residences, occupation, national identification number of the plaintiff and the defendant.

2- Determination of the extent of the subject matter of the claim and a summary of the purpose of the claim.

3- Declaration of the nature, type and price of the subject matter of the claim, in case it is moveable.

If the subject matter of the claim is a piece of land, a mention of its location, type and area is also necessary.

4- Signature or fingerprint of the requesting party.

If the requesting party is a proxy, executor or curator, a mention of the number and date of power of attorney document, executorship and custodianship with their full identification is necessary.

5- Date of the establishment of the right and the date of the presentation of the request.

\section{ARTICLE FOURTEEN}

If the subject matter of the claim is common and there are multiple plaintiffs, claim for relief is made by a single request.

\section{ARTICLE FIFTEEN}

If there is a single ground for the claim in the subject matter of the claim, and there are multiple defendants, petition is made through a single request letter.

\section{ARTICLE SIXTEEN}

1- As for the request that is submitted to the authorized court, the court examines the request after summoning the party against whom the request is made and, in case of consent by the latter, issues a legal writ and refers it to the legal office for its execution.

2- In case of a denial by the person against whom the request has been made, the court shall proceed according to the rules of the law.

\section{ARTICLE SEVENTEEN}

In the absence of consent of the party against whom the request is made with the parties, the request that is presented to the legal office is assigned to the court. 


\section{CHAPTER TWO: \\ SOURCES OF CLAIM}

\section{ARTICLE EIGHTEEN}

The office of the authorized court's documents receives the incoming requests and, after they are reviewed by the president of the court, records it in the relevant office.

\section{ARTICLE NINETEEN}

If the court considers itself incompetent to hear the case, it shall issue a ruling of dismissal of the claim.

\section{ARTICLE TWENTY}

In a case in which preliminary objections are made, the court shall hear the objections in a legal proceeding determined by the court and shall take a legal decision to that effect.

\section{ARTICLE TWENTY-ONE}

Preliminary objections are as follows:

1- Lack of jurisdiction by the court to hear the case.

2- Lack of legal capacity on the part of the plaintiff and the defendant.

3- Inapplicability of the claim contained in the pleading to the defendant.

4- Issuance of a prior legal ruling related to the issue at dispute between the requesting party and the party against whom request is made.

5- Absence of documented proof of the possession of the immovable subject matter of the claim.

6- Relation of the case with a claim that is under proceedings in another court.

7- The case contained in the request being heard in another court.

8- The case being subject to the limitation period.

\section{ARTICLE TWENTY-TWO}

In situations that are contained in Article 21 of this Code, the legal panel shall hear the matter in the presence of the parties and shall issue a legal ruling and announce it to the parties.

\section{ARTICLE TWENTY-THREE}


The party not satisfied with the legal ruling issued pursuant to Article 22 of this Code can present its objection to the setting court or the superior court within twenty days. In this case, the setting court is obligated to give to the objecting party a date-stamped receipt and refer the objection to the superior court after recording it in the relevant office.

\section{ARTICLE TWENTY-FOUR}

The period of presentation of the claim and response to it cannot be more than fifteen days, unless reasonable excuse is given.

\section{ARTICLE TWENTY-FIVE}

The office of the court documents is obligated to give a date-stamped receipt related to the receipt of the claim paper, response to the claim and their annexes to the plaintiff and defendant.

\section{ARTICLE TWENTY-SIX}

The office of the court documents shall, after receipt of the claim, in case it is determined by the legal panel to be accurate, proceed with the issue according to the law and, with the written order of the president of the court, record the claim (x) in the specific form and give a copy of it at a specific time to the defendant for the purpose of preparing the response.

In case of inaccuracy of the claim, the plaintiff is bound to correct the claim.

\section{ARTICLE TWENTY-SEVEN}

After the preparation of response by the defendant, the court shall announce the date of the trial to the parties.

\section{ARTICLE TWENTY-EIGHT}

In simple claims and in claims that require speedy trial, the proceedings take place by taking into account the request for relief and the oral declarations of the parties.

Simple claims depend on the determination of the authorized court, in view of the environment and circumstances of the plaintiffs.

\section{ARTICLE TWENTY-NINE}

If the plaintiff does not present his/her claim to the court within the legal time period, the court shall issue a legal ruling dismissing the claim and shall return the request to the concerned authorities.

\section{ARTICLE THIRTY}


If the defendant does not present his/her written response to the court within the specified time period, the court shall rely on his/her oral response and hold legal proceedings concerning the issue.

\section{ARTICLE THIRTY-ONE}

If the plaintiff approaches the court after the issuance of the legal ruling pursuant to Article 29, the court shall demand the background information regarding the matter and shall, after summoning the opposing party, proceed with the issue.

The plaintiff is obligated to pursue his/her claim in this situation.

\section{ARTICLE THIRTY-TWO}

If the plaintiff does not attend the hearing of his/her claim for the second time and does not inform the court of his/her legal excuse, the court shall again issue a ruling of dismissal of the case.

\section{ARTICLE THIRTY-THREE}

According to the provisions of Article 32, this Code is subject to the provisions relating to appeal, unless the law has provided otherwise.

\section{ARTICLE THIRTY-FOUR}

1- A court that has issued a ruling pursuant to the provisions of Article 32, and that ruling has been overruled by a superior court, the former is obligated to hold (new) proceedings concerning the case.

2- The superior court is obligated to announce to the parties its decision to overrule the ruling of the lower court and to order a re-trial of the case by the lower court.

\section{ARTICLE THIRTY-FIVE}

After arrival of the case in office of the court for the purpose of retrial, the plaintiff is obligated to bring within one month its claim to the relevant court. In case the plaintiff does not without legal excuse bring its claim within the specified time period, the court shall issue a ruling of dismissal and this ruling shall be the final ruling.

\section{ARTICLE THIRTY-SIX}

In a claim relating to marriage, the plaintiff is obligated to submit its claim for purpose of the trial proceeding within one month to the relevant court in the absence of a proper excuse from the date of the arrival of request. With the expiry of this period, the court can issue a ruling of dismissal. The plaintiff is given the right of appeal only once. 
If the trial court issues a ruling of dismissal for the second time, this ruling shall be final.

\section{ARTICLE THIRTY-SEVEN}

The court has the following offices:

1- Book of records and filing

2- Book of records of criminal files

3- Book of records of civil and commercial cases

4- Agenda of trial of urgent cases

5- Agenda of trial of ordinary cases

6- Form of the judicial ruling papers

7- Form of records of the judicial ruling papers

8- Form of the original and records of the judicial rulings

9- Office of accounting of executors

10- Office of recording of complaints and objections to the final and non-final judgments of the courts of the provinces

11- Office of appeals registration

12- Declaration

13- Book of records of customs documents

14- Exhibit

15- Book of record of requests

16- Office of custom's tariffs

17- Office of attendance

18- Office of supervision of absolute decisions 
19- Other needed offices

\section{ARTICLE THIRTY-EIGHT}

The number and type of offices and books of courts vary according to the specifics of the working of every court and each one of the courts according to the specifics of its work utilizes the offices provided for in Article 37 of this Code.

\section{ARTICLE THIRTY-NINE}

Subject to the provisions of this Code, other responsibilities of the administrative personnel of the courts are regulated by separate terms of reference that is approved by the high council of the Supreme Court.

\section{CHAPTER THREE: PROCEEDINGS OF CIVIL CASES IN COURTS}

\section{ARTICLE FORTY}

Proceedings of all the civil cases in the courts of Afghanistan shall be public, unless such public hearing adversely affects public order or leads to the exposure of the secrets of the people's lives.

\section{ARTICLE FORTY-ONE}

Public hearings are held on official days and interested persons are allowed to attend.

\section{ARTICLE FORTY-TWO}

The judgment of the court in all situations is announced publicly.

\section{ARTICLE FORTY-THREE}

Proceedings in the camera are held in the presence of persons involved in the case and their legal representatives and, if needed, witnesses, experts and interpreter shall also attend the proceedings.

\section{ARTICLE FORTY-FOUR}

A person who has not completed the age of 15 and who is not involved in the case cannot attend the judicial hearing.

\section{ARTICLE FORTY-FIVE}

The office of the court documents is obligated, prior to the holding of the hearing, to place the plaintiff, defendant or their legal representative, witnesses, experts and interpreter in the specifically assigned places. 


\begin{abstract}
ARTICLE FORTY-SIX
The judicial panel shall enter the hearing chamber when the time of the hearing has approached and the persons mentioned in Article 45 have attended.
\end{abstract}

\title{
ARTICLE FORTY-SEVEN
}

Upon the entry of the judicial panel into the hearing chamber, all those in attendance shall stand up and when the judges take their seats, they shall sit down.

\section{ARTICLE FORTY-EIGHT}

The presiding judge opens the official hearing in the name of God, the Almighty and Just, informs the attendees of the composition of the judicial panel, prosecutor and experts, interpreter and the secretary of the session.

\section{ARTICLE FORTY-NINE}

The presiding judge explains the rights, duties and responsibilities of the persons involved in the case and in the hearing and instructs the secretary of the judicial session to read out the agenda of the hearing; and, after introducing the plaintiff, the defendant or their legal representative shall commence the proceedings of the case.

\section{ARTICLE FIFTY}

During the proceedings, the chairman of the session shall first allow the plaintiff or his/her legal representative and then the defendant or his/her representative to read out their claim and defense.

\section{ARTICLE FIFTY-ONE}

The parties to the claim shall freely read out their respective statements and give explanations. Before one side has ended reading its statement, the other side does not have the right to interrupt the statement of that side.

\section{ARTICLE FIFTY-TWO}

It shall be within the authority of the presiding judge to demand explanations from the plaintiff, the defendant and other persons involved. If during the trial there are issues concerning which the members of the judicial panel require explanation, the parties shall accordingly be questioned, with the permission of the presiding judge.

\section{ARTICLE FIFTY-THREE}

The secretary of the trial session is obligated to record without any addition or omission in the book of the records of the session all the proceedings of the trial in relation to the claim and 
defenses, testimony of witnesses and declarations of the experts, and obtain the signature of the president and the relevant persons at the end of the trial.

\section{ARTICLE FIFTY-FOUR}

The leadership and management of the judicial hearing shall be within the authority of the presiding judge.

\section{ARTICLE FIFTY-FIVE}

The persons involved in the case, the legal representative of the parties to the claim, the witnesses, the experts, the interpreters and others involved in the judicial hearing are obligated to observe the orderly conduct of the trial and to follow the orders of the presiding judge.

\section{ARTICLE FIFTY-SIX}

The plaintiff, the defendant or their legal representative, the witnesses, the experts and the interpreters are obligated to stand up while reading their statements and while explaining issues, unless the presiding judge gives them permission to sit down.

\section{ARTICLE FIFTY-SEVEN}

The presiding judge shall warn the person who disturbs the order of the hearing. In case of violation, the presiding judge can expel the persons creating the disturbance from the trial chamber.

\section{ARTICLE FIFTY-EIGHT}

If those disturbing the orderly conduct of the hearing are the plaintiff, the defendant or their legal representative and, in case such violation is repeated, the court can impose a monetary fine of no more than three thousand Afghanis or a sentence of imprisonment of up to one week upon such a person.

\section{ARTICLE FIFTY-NINE}

If the person disturbing the order of the hearing is a civil prosecutor, the court shall, by issuing a judicial ruling, take an action to replace him.

\section{ARTICLE SIXTY}

If the person who disturbs the order of the hearing is a defense attorney, the court shall discipline him/her according to the provisions of law.

\section{ARTICLE SIXTY-ONE}


If a person commits the crime of obscenity or a misdemeanor during the hearing, he/she shall be punished by the court according to the provisions of the law.

\section{ARTICLE SIXTY-TWO}

The court shall determine the mandatory punishments provided for under Articles 58 to 60 of this Code and the judgment of the court to this effect shall not be subject to appeal.

\section{ARTICLE SIXTY-THREE}

In situations provided for under Articles 58 to 60 of this Code, the court can cancel the judgment that has been issued prior to the end of the hearing.

\section{ARTICLE SIXTY-FOUR}

In case of a misdemeanor, if the court does not convict the accused in the same hearing session, or if the wrongdoing is a crime, the court is obligated to prepare the records of the incident and issue an order for the arrest of the accused and refer the issue to the relevant prosecutor. Issuance of judgment in this regard takes place in the nearest court.

\section{CHAPTER FOUR: \\ RECUSAL AND REJECTION OF JUDGE}

\section{ARTICLE SIXTY-FIVE}

The president and the members of the court shall each remove himself/herself from the composition of the trial and hearing of a civil action in the following situations:

1- If he/she is an interested party in the case before the court or if the claim is related to the principals and proxies, husband, wife or their relatives. For this purpose, "relatives" means brother and sister and their respective children (nephew/niece), uncle and aunt (on both the mother's side and the father's side), father-in-law and mother-in-law.

2- If he/she has written or signed a document related to the case before the court, or if he/she, acting as a prosecutor, has already made a judgment as to the subject matter of the claim or, as an expert or witness, has already expressed an opinion.

3- If there is a conflict between the president and the members of the court or one of the parties to the case.

4- If there is an existing enmity between the president and the members of the court or one of the parties to the case.

\section{ARTICLE SIXTY-SIX}


The judges that pursuant to the provision of clause 1 of Article 65 of this Code are related to each other cannot be involved in the composition of the trial and the hearing of the civil case.

\section{ARTICLE SIXTY-SEVEN}

In case of the occurrence of circumstances beyond those provided for under Articles 65 and 66 of this Code, a judge can refuse to participate in the hearing of a case.

\section{ARTICLE SIXTY-EIGHT}

Involvement of the president and the members of the court in the subsequent hearing is not allowed in the following situations:

1- In case of participation in the preliminary hearing of the case.

2- In case of participation in the hearing of the case before the tribunals of the Supreme Court.

\section{ARTICLE SIXTY-NINE}

In situations provided for under Articles 67 and 68 of this Code, the judge is obligated to submit to the court his/her recusal from the case.

\section{ARTICLE SEVENTY}

The parties to a claim can in case of the existence of one of the situations provided for under Articles 67 and 68 of this Code request the exclusion of a judge from the proceedings of the case.

\section{ARTICLE SEVENTY-ONE}

A demand for exclusion/rejection of the judge is submitted to the court in a written and documented form within three days prior to the commencement of proceedings of the case.

\section{ARTICLE SEVENTY-TWO}

1- The judicial panel of the court shall examine during a judicial hearing the grounds and reasons for the rejection, and shall make a decision and issue a ruling with a majority of opinions regarding acceptance and non-acceptance.

2- If opinions are evenly divided, rejection of the judge is preferred.

\section{ARTICLE SEVENTY-THREE}

If there is one judge in the preliminary court, the request for rejection is presented to the superior court and, in case of acceptance of the rejection, another judge is assigned to hear the case. 


\section{ARTICLE SEVENTY-FOUR}

If demand for rejection is directed against the whole judicial panel of the preliminary court, in case of the acceptance of rejection, another judicial panel is assigned for the purpose of hearing the claim and issuance of judgment by the superior court.

\section{ARTICLE SEVENTY-FIVE}

If the grounds for rejection are directed against the judicial panel of one of the tribunals of the state court or an equivalent court, the president of the court shall with the participation of another judge make a decision regarding acceptance or non-acceptance of the rejection.

If the grounds of rejection are directed against the head of the state court, an equivalent court or against members of the Supreme Court, the high council of the Supreme Court shall make a decision regarding this matter.

\section{ARTICLE SEVENTY-SIX}

When the rejection of a judge is at issue, the hearing of actual claim shall be postponed.

\section{ARTICLE SEVENTY-SEVEN}

If the grounds for rejection of the judge are not proven, the court deciding that there is no proof to allow rejection shall impose a monetary fine of up to three thousand Afghani upon the party requesting the rejection in bad faith (plaintiff or defendant).

\section{ARTICLE SEVENTY-EIGHT}

The rulings that are issued by the court regarding rejection shall be final.

\section{CHAPTER FIVE: JURISDICTION IN CIVIL CASES \\ ARTICLE SEVENTY-NINE}

Civil claims at the trial stage shall be decided by the city, municipal, district or sub-district courts, except in situations where the law provides otherwise.

\section{ARTICLE EIGHTY}

The court shall take measures to hear claims whose solution has been requested by legal or juridical personalities.

\section{ARTICLE EIGHTY-ONE}

1- Civil claims are resolved in the defendant's place of residence. 
2- In case the defendant possesses multiple residences, civil claims against him/her are heard in such court in whose jurisdiction the defendant resides while making the claim.

\section{ARTICLE EIGHTY-TWO}

If the defendant is a married woman, the hearing of the case shall be within the jurisdiction of the court located in the place of residence of the husband.

\section{ARTICLE EIGHTY-THREE}

In the defendant is a girl who has attained the age of marriage (age of majority) or who possesses full legal capacity, the court which is located in the place of residence of her father or her close relatives who are responsible for her feeding and upbringing shall have jurisdiction to hear the claim.

\section{ARTICLE EIGHTY-FOUR}

If the defendant lacks legal capacity or is not competent, the court located in the place of residence of the guardian, administrator or custodian shall have jurisdiction to hear the claim.

\section{ARTICLE EIGHTY-FIVE}

The place of residence of interdicted, missing and absentee persons shall be the residence of their legal representative.

\section{ARTICLE EIGHTY-SIX}

If the defendants are employees of the government, appointees of the armed forces in civil cases, the court which is located in the place of their employment shall have jurisdiction to hear the claim.

\section{ARTICLE EIGHTY-SEVEN}

Claim by a traveler or nomad, in case they are the plaintiff or defendant, are heard in the city, municipal, district or sub-district courts, if both parties accept the jurisdiction of the relevant court.

\section{ARTICLE EIGHTY-EIGHT}

If either of the parties to the claim has an objection to the jurisdiction of the court to hear the claim, it shall present its objection to the same court before the commencement of the hearing; otherwise, the jurisdiction of the court is considered accepted.

\section{ARTICLE EIGHTY-NINE}


If the defendant has spent at least one year in the place of residence of the plaintiff, the court located in the place of residence of the plaintiff shall have jurisdiction.

\section{ARTICLE NINETY}

In claims related to the civil contracts of a trader or a professional person as defendants, the court located at the place of the trade, profession or the court of the place of his/her actual residence shall have jurisdiction.

\section{ARTICLE NINETY-ONE}

If a place of residence is chosen for the purpose of the performance of a specific legal dealing, the court with jurisdiction to hear a claim arising from such dealing shall be the court located in that chosen residence.

\section{ARTICLE NINETY-TWO}

Hearing of a claim related to the division or assignment of bequest shall be within the jurisdiction of the city, municipal, district or sub-district courts within whose jurisdiction the property subject to the division or assignment is located.

In case of the existence of the property in different jurisdictional zones, the court in whose territory the major part of the property is located shall have jurisdiction to conduct the proceedings.

\section{ARTICLE NINETY-THREE}

A case cannot be transferred to another court after a hearing has commenced in a court and after it has been recorded in the special form. In case of a recusal by the judge or a rejection of the judge by the defendant, another judicial panel shall be assigned in the same court to hear the claim.

\section{ARTICLE NINETY-FOUR}

If the spatial or the factual jurisdiction of the court is changed pursuant to the enactment of a new law, the court in which the claim is being heard shall have jurisdiction.

\section{ARTICLE NINETY-FIVE}

Hearing of the claims related to foreign citizens residing in Afghanistan shall be within the jurisdiction of the courts of the Republic of Afghanistan.

\section{ARTICLE NINETY-SIX}


In a claim related to a foreign citizen that does not have a place of residence in Afghanistan, the courts of the Republic of Afghanistan shall have jurisdiction to hear such a claim in the following situations:

1- In case the foreigner has a residence of choice in the Republic of Afghanistan.

2- In case the subject of a contract or the place of its implementation is the Republic of Afghanistan.

3- In case the claim related to a demand for division/assignment of bequeathed property has commenced in the Republic of Afghanistan.

4- In case the whole or part of the bequeathed properties is in the Republic of Afghanistan.

\section{ARTICLE NINETY-SEVEN}

Hearing of a claim related to separation for reason of the absence of husband or his being missing shall be within the jurisdiction of the court located in the place of residence of the plaintiff.

\section{ARTICLE NINETY-EIGHT}

Hearing of a claim of confirmation for reasons of detention of husband according to the provisions of the law shall be within the jurisdiction of the court that is located in the place of detention of the husband.

\section{ARTICLE NINETY-NINE}

Hearing of a claim for reason of harm against a wife by a husband who has a place of residence or a place of stay in Afghanistan, whereby he has left his wife and has escaped abroad after causing the harm, shall be held in the court of the place of residence of the wife.

\section{ARTICLE ONE HUNDRED}

An authorized court to hear a claim against a person who has left Afghanistan without legal reason shall in the following situations be the court of the place of residence of the plaintiff:

1- Claim related to maintenance of wife, the principal and the interest.

2- Claim related to proof of lineage.

3- Claim related to revocation of guardianship.

4-Claim related to revocation of executorship and custodianship. 


\section{CHAPTER SIX: \\ PROCEEDINGS RELATED TO FAMILY CASES \\ ARTICLE ONE HUNDRED ONE}

The following matters shall fall within the family cases:

1- Marriage and rights arising from it.

2- Rights arising from marital relationship.

3- Financial disputes arising from marital relationship.

4- Claim related to lineage.

5- Issues related to protection and maintenance of child.

6- Dissolution of marriage for whatever reason.

7- Issues related to an absentee and missing husband.

8- Other issues that are considered as part of family cases according to the provisions of law.

\section{ARTICLE ONE HUNDRED TWO}

1- Relinquishing a claim of engagement in case of transfer to the court is heard within the judicial ruling.

2- The ruling of the court regarding relinquishment of the claim of engagement is final and cannot be heard by a higher court.

\section{ARTICLE ONE HUNDRED THREE}

Return of gifts can only be demanded from fiancé according to the provisions of the law.

\section{ARTICLE ONE HUNDRED FOUR}

1- The court shall prior to the commencement of the proceedings of the claim assure itself of the accuracy of the marriage.

2- Information as to the accuracy of the marriage shall be obtained from those present in the marriage ceremony.

\section{ARTICLE ONE HUNDRED FIVE}


The proceedings and hearing of a claim by the court after receipt of information regarding the process of the claim related to marriage or the rejection of the claim take place within the judicial ruling and this ruling shall be absolute.

\section{ARTICLE ONE HUNDRED SIX}

1- If during the proceedings of a claim related to marriage, a dispute emerges regarding the place of residence of the defendant, the court shall make a determination to specify the place of residence of the defendant by taking into consideration the interests of the parties.

2- The place of residence of father, grandfather, brother and close relatives of the woman (wife) and the location of welfare organizations are taken into account by the court when it determines the place of residence of wife.

\section{ARTICLE ONE HUNDRED SEVEN}

If the woman (wife) is a resident in one of the places specified in clause 2 of Article 106 of this Code, resolution of the claim is subject to urgent agenda.

\section{ARTICLE ONE HUNDRED EIGHT}

Bringing a claim for dissolution of marriage of the wife for reason of absence of (legal) capacity to marry at the time of marriage is not allowed after completion of the age of 17 .

\section{ARTICLE ONE HUNDRED NINE}

Determination of capacity to marry shall be made according to the provisions of Chapter Ten of this Part.

\section{ARTICLE ONE HUNDRED TEN}

In a claim of separation for reason of harm, if the harm in question is not justified and if the court envisions a fear of disagreement and division between the husband and wife, the court shall assign two just persons, one from the relatives of the husband and another from the relatives of the wife as a arbitrators for the purpose of repairing their relationship.

\section{ARTICLE ONE HUNDRED ELEVEN}

In a claim of separation for reasons of harm, an arbitrator cannot be assigned more than twice.

\section{ARTICLE ONE HUNDRED TWELVE}

The court shall issue a justified judgment based on the reasons and evidence provided by the two arbitrators.

\section{ARTICLE ONE HUNDRED THIRTEEN}


In claims of separation for reason of harm no oath shall administered.

\section{ARTICLE ONE HUNDRED FOURTEEN}

If the defect of the husband is not removed within one year, the court shall by taking into account the provisions of Article 179 of Civil Law order separation between the husband and wife.

\section{ARTICLE ONE HUNDRED FIFTEEN}

In a claim of separation for reason of absence, if the husband possesses a place of residence which is clear and specific, the court shall serve a written notice on the absentee husband and shall specify a time period for his return to the residence of his wife or shall require him to return to his own residence.

\section{ARTICLE ONE HUNDRED SIXTEEN}

In case the absentee husband continues to be absent, despite the receipt of the notice from the court and the expiry of the time specified therein, the court shall by assigning an agent for the absentee (husband) adjudicate the issue.

\section{ARTICLE ONE HUNDRED SEVENTEEN}

In case the absentee husband does not possess a clear and specific residence, or if the service of the written notice upon the absentee husband is not possible, the issue specifying the time period for (his) appearance shall be announced through radio. The time period for this purpose cannot be less than one month from the time of the announcement.

\section{ARTICLE ONE HUNDRED EIGHTEEN}

If the absentee husband continues to be absent without legal justification despite the radio announcement, the court shall proceed with the issue by assigning an agent for the absentee (husband).

\section{ARTICLE ONE HUNDRED NINETEEN}

In view of the provisions of Article 326 of the Civil Law, a claim for the dissolution of marriage against a missing husband whose state of life or death is not clear is not allowed before the expiry of a period of four years.

\section{ARTICLE ONE HUNDRED TWENTY}

In determining a judgment and issues related to it and the rejection of claims of separation for reasons of defect, harm, absence of maintenance and absence of the husband, the court shall also observe the rules of the Civil Law. 


\section{CHAPTER SEVEN: \\ PROCEEDINGS RELATED TO PUBLIC INTEREST CASES}

\section{ARTICLE ONE HUNDRED TWENTY-ONE}

Requests related to the public interest claims are directly submitted to the Kabul city court, state courts or main district court, and proceedings related to them take place as follows:

1- Written notice of the contents of the request to the office of government cases.

2- Demand for background information regarding the case, the presence of representative of the office of government cases and the legal representative of legal persons along with specifying the date.

3- Listening to the statements and defenses of the parties to the case in the preliminary hearing.

\section{ARTICLE ONE HUNDRED TWENTY-TWO}

If the court, after listening to the statements and the defenses and as a result of evaluating the reasons presented by both parties, concludes that the resolution of the dispute requires a hearing, it shall issue a ruling in favor of the proceedings of the claim.

\section{ARTICLE ONE HUNDRED TWENTY-THREE}

In case the court concludes in the preliminary hearing that the dispute actually does not require a court proceeding, it shall declare the claim as non-justiciable.

\section{ARTICLE ONE HUNDRED TWENTY-FOUR}

The judicial ruling provided for under Article 122 of this Code is not final and can, as a result of complaint by a party to the case or of an objection by the representative of the office of the government cases can be heard again in a tribunal related to the Supreme Court.

\section{ARTICLE ONE HUNDRED TWENTY-FIVE}

If the satisfaction of the opposing party in a case that is referred to the office of the government cases is not obtained without hearing by the court, the office of government cases shall refer the case to the court for the purpose of resolution.

\section{ARTICLE ONE HUNDRED TWENTY-SIX}

In relation to the matters that are referred to the court by the office of the government cases, compliance with the provisions of Articles 122 and 123 of this Code is mandatory.

\section{ARTICLE ONE HUNDRED TWENTY-SEVEN}


The court in a public interest claim shall issue its judgment based on sources of proof, such as documents and witnesses.

\section{CHAPTER EIGHT: \\ NOTICE, SUMMON AND APPEARANCE \\ ARTICLE ONE HUNDRED TWENTY-EIGHT}

The court shall directly inform the party to a claim or summon him/her through relevant authorities.

\section{ARTICLE ONE HUNDRED TWENTY-NINE}

The court can request the presence of an expert and a third party whose statements for the clarification of the case are effective.

\section{ARTICLE ONE HUNDRED THIRTY}

If either party does not come to the court on the day specified, it shall be summoned by the court.

\section{ARTICLE ONE HUNDRED THIRTY-ONE}

One original and two copies of the summons form are prepared and shall contain the following:

1- Name and address of the court.

2- Identity and accurate address of parties to the claim.

3- Date and time of presence.

4- Introduction of the issue.

5- Reminders to the person summoned regarding preparation and presentation of documents related to the issue.

6- Warning about consequences of non-appearance

\section{ARTICLE ONE HUNDRED THIRTY-TWO}

The court can request in any manner possible, including telephone and telegraph, the presence of the parties to the claim, witnesses and experts.

\section{ARTICLE ONE HUNDRED THIRTY-THREE}

The summons form of the court shall be issued to the office of summons and appearance together with an official letter. 


\section{ARTICLE ONE HUNDRED THIRTY-FOUR}

The office of summons and appearance is obligated to give the summons form to the relevant person or his legal representative, and to obtain his signature and agreement to appear on the second copy and send it to the court.

\section{ARTICLE ONE HUNDRED THIRTY-FIVE}

If the person summoned is illiterate, his fingerprint shall be put on paper in a professional and clear manner.

\section{ARTICLE ONE HUNDRED THIRTY-SIX}

In case the person summoned refuses to sign or give his fingerprint, the matter shall be recorded in the form accordingly and the signature of one of the followings persons is taken on it:

1- Signature of the head of the council of the place of residence or two neighboring persons or residents of the place.

2- Signature of the head of the office of summons and, in case the person refusing is a worker of the government office or organizations, the signature of the head of the concerned office.

\section{ARTICLE ONE HUNDRED THIRTY-SEVEN}

The office of summons and appearance shall in compliance with the steps provided for in Article 136 return the form to the court together with an official letter.

\section{ARTICLE ONE HUNDRED THIRTY-EIGHT}

If the person summoned is a staff member of the government offices, organizations or companies, the summons form can also be sent to his relevant office.

\section{ARTICLE ONE HUNDRED THIRTY-NINE}

If finding the person is temporarily postponed for some reasons, the relevant places are obligated to officially inform the court of the issues and, after the removal of the obstacles, shall proceed with processing of the summons form.

\section{ARTICLE ONE HUNDRED FORTY}

If the person summoned is an escapee, absentee or missing the documents related to his/her investigations shall be completed and the matter recorded in the summons form and then sent to the court.

\section{ARTICLE ONE HUNDRED FORTY-ONE}


If the person summoned is a member of the armed forces, the summons form is served on him through the relevant military squad/unit.

\section{ARTICLE ONE HUNDRED FORTY-TWO}

If the steps contained in this Code are not observed in the summons form, the form is returned by the court to the relevant authorities for completion, and the authorities issuing the summons are obligated to complete the steps of the form.

\section{ARTICLE ONE HUNDRED FORTY-THREE}

If the person summoned appears before the court and if his subsequent appearance in the following hearing sessions is also necessary, the date of the next hearing session for the purpose of appearance is announced to him and the proceeding recorded in the concerned office.

\section{ARTICLE ONE HUNDRED FORTY-FOUR}

If it is feared that a party to the claim withdraws or escapes, the court can force him to guaranty his/her presence.

\section{ARTICLE ONE HUNDRED FORTY-FIVE}

If the person summoned pursuant to the summons contained in the summons and appearance form issued by the authorities issuing summons and request for appearance refuses to reappear in the court, the court shall summon him for the second or third time.

\section{ARTICLE ONE HUNDRED FORTY-SIX}

If the person summoned despite implementation of the provisions of Article 145 of this Code still does not appear in the court, or according to Article 140 of this Code, he/she is considered an escapee, absentee or missing, the request for his presence during the time specified by the court is made for the last time through radio or a popular and widely-circulated newspaper.

\section{ARTICLE ONE HUNDRED FORTY-SEVEN}

If the person summoned refuses to appear in the court at the specified time without reasonable excuse, the court shall issue judgments in absentia regarding him/her.

\section{ARTICLE ONE HUNDRED FORTY-EIGHT}

The court summons and requires the appearance of the parties to the claim based on the date of the agenda. Expedited claims are exempt from this rule.

\section{ARTICLE ONE HUNDRED FORTY-NINE}


The time of presence of the person summoned is made by the court at its discretion based on the distance of his/her place of residence and the availability of transportation

\section{ARTICLE ONE HUNDRED FIFTY}

Any reluctance on the part of the places/offices of summons and appearance as contained in this Chapter shall be announced to the head offices of these offices by the court in order that the office/person in violation is subject to legal questioning.

\section{ARTICLE ONE HUNDRED FIFTY-ONE}

The court shall control the implementation of the rule of Article 150 of this Chapter every fifteen days.

\section{ARTICLE ONE HUNDRED FIFTY-TWO}

The office of the court documents is responsible to the president of the court for the implementation of the rules contained in this Chapter.

\section{CHAPTER NINE:}

\section{ABSENT RULES}

\section{ARTICLE ONE HUNDRED FIFTY-THREE}

If the applicant does not follow his/her application in the court within 30 days of the recorded claim, a ruling of dismissal of the claim shall be issued in his/her absence according to the rules of this Code.

\section{ARTICLE ONE HUNDRED FIFTY-FOUR}

If the plaintiff submits his/her claim to the court and after commencement of the proceedings of the claim he/she disappears without legal excuse, the court shall summon the plaintiff according to the rules of Chapter 8 of this Part and, in case he/she does not appear in the court within the specified time period, a decision of dismissal shall be issued.

\section{ARTICLE ONE HUNDRED FIFTY-FIVE}

If the defendant confesses after a claim has been brought by the plaintiff, and at the time of the issuance of judgment the defendant retracts his/her confession, if he/she disappears after the testimony of witnesses, the court shall in both cases consider the defendant as legally present and shall issue a judgment in the matter.

\section{ARTICLE ONE HUNDRED FIFTY-SIX}

If the plaintiff expresses inability to present witnesses and requests an oat by the opposing party, but during the performance of the oath he/she withdraws himself/herself (from the proceedings), 
the court shall consider the plaintiff as legally present and shall issue an order for the taking of an oath or a withdrawal by the defendant.

\section{ARTICLE ONE HUNDRED FIFTY-SEVEN}

In cases where the return of an oath is allowed, if the defendant returns the taking of the oath to the plaintiff, and the plaintiff disappears thereafter, the court shall rule for the withdrawal of the plaintiff.

\section{ARTICLE ONE HUNDRED FIFTY-EIGHT}

If the defendant after the submission of request does not actually appear pursuant to the summons, or if he/she disappears before the commencement of the claim or thereafter, and the plaintiff insists on the resolution of the issue, the court shall in compliance with the rules of Chapter 8 of this Part take appropriate actions, and after the specified time has become due, one of the close relatives in the first degree shall assign a representative for the absentee husband or wife and proceed with the hearing of the claim.

\section{ARTICLE ONE HUNDRED FIFTY-NINE}

If the relatives in the first degree are absent, her/his husband or wife does not qualify to be a representative or his/her relatives refuse to accept becoming a representative, as a result of written recommendation of the court, the civil prosecutor is assigned as the representative of the absentee (party) and the claim is heard.

\section{ARTICLE ONE HUNDRED SIXTY}

Assignment of a representative for the absentee person by the court takes place within the papers of judgment. This representative shall possess the defensive authorities of the absentee person.

\section{ARTICLE ONE HUNDRED SIXTY-ONE}

If the absentee defendant has reasonable excuse and has given notice to the court, the hearing of the case is postponed up to two months for the purpose of removal of the excuse.

\section{ARTICLE ONE HUNDRED SIXTY-TWO}

If the period of postponement exceeds the two months, the court can take action by using the possible legal means, and in special situations the court can extend the said time period.

\section{ARTICLE ONE HUNDRED SIXTY-THREE}

1- If the absentee person makes an appearance after being assigned by the court, the trial shall take place in his presence. 
2- If his absence is repeated or is a result of disobedience or distress against the opposing side, this appearance shall have no validity and the trial shall proceed in the presence of the representative assigned by the court.

\section{ARTICLE ONE HUNDRED SIXTY-FOUR}

If in the face of the defendant's defense, the oath is returned to the plaintiff and thereafter the defendant disappears, in such a case the court on behalf of the absentee person appoints a representative and returns the oath to the actual plaintiff. The oath and refusal in such situations have legal effects.

\section{ARTICLE ONE HUNDRED SIXTY-FIVE}

If the plaintiff does not have witnesses and demands the oath of the absentee defendant, the court shall issue a judgment pending the oath by the absentee party.

\section{ARTICLE ONE HUNDRED SIXTY-SIX}

If the defendant appears in the court during a period of two months, but declines to take an oath in the court, this refusal shall be actual denial and the non-appearance of the defendant in the court without reason during the specified time period as stated shall be legal denial. In both cases, the court shall issue a judgment for his refusal.

\section{ARTICLE ONE HUNDRED SIXTY-SEVEN}

1 - If the absentee defendant appears during the specified time period and takes an oath against the claim of the plaintiff, a judgment of dismissal shall be issued.

2- Readiness of the defendant to take the oath after the expiry of the period of two months is not valid.

\section{ARTICLE ONE HUNDRED SIXTY-EIGHT}

If the guardian, executor, custodian or the proxy of the absentee do not follow up the claim, the court shall not make a judgment of dismissal due to non-appearance and non-follow-up, and in the face of continuing absence shall assign another person as legal representative instead of the custodian, executor or proxy of the absentee and, in case of cancellation of the guardianship, shall assign another guardian as executor and shall issue its judgment in the matter.

\section{ARTICLE ONE HUNDRED SIXTY-NINE}

If the proxy/attorney of the plaintiff does not follow the claim of the latter, the court shall notify the latter only once, and in case of the presence of the latter or with the assignment of a new proxy it shall act to resolve the claim and, in case of a lack of attention by the latter to the notification, the court shall issue a ruling of dismissal. 


\section{ARTICLE ONE HUNDRED SEVENTY}

1- The absent representative is not authorized to make a confession, give a waiver, amendment, satisfaction and other actions that are detrimental to the absentee party.

2- The authority of the assigned representative ends by the court pursuant to the provisions of Article 163 after notification and presence by the absentee party.

\section{ARTICLE ONE HUNDRED SEVENTY-ONE}

The party representing public interests is not authorized to make a confession, give a waiver, and make an amendment, unless otherwise provided for in the law.

\section{ARTICLE ONE HUNDRED SEVENTY-TWO}

Judgments in absentia are announced to the representative and are brought to the attention of the convicted person. In case of the impossibility of announcing it to the convicted person, the notice is delivered to one of the members of the absentee's family and, in the case of non-existence of members of the family, is submitted to the office of their place of residence or to the office of their workplace.

\section{ARTICLE ONE HUNDRED SEVENTY-THREE}

The absentee's proxy/attorney and the public rights representative do not have the authority of satisfaction regarding the issued judgment by the court.

\section{ARTICLE ONE HUNDRED SEVENTY-FOUR}

The court's judgments designating representative are also applicable in claims for separation due to the husband being absent or missing.

\section{CHAPTER TEN: USE OF EXPERTS AND INFORMED PERSONS IN CIVIL CASES}

\section{ARTICLE ONE HUNDRED SEVENTY-FIVE}

1- For the purpose of clarification of facts related to the claim and pursuant to the request of the parties, the court can demand the opinions of the experts who based on their profession and expertise possess sufficient information and based on standards of Islamic law possess good character and attributes.

2- Before commencing his activity, the expert shall swear that he/she shall perform his/her duty with trustworthiness.

\section{ARTICLE ONE HUNDRED SEVENTY-SIX}


1- In claims related to land, the court can seek information from the experts about the price of the land, determination of limits, area and structural matters and in case of the emergence of differences between the parties to the claim.

2- The court can seek information from the experts in claims related to moveable properties regarding the determination of the price of the subject matter of the claim.

\section{ARTICLE ONE HUNDRED SEVENTY-SEVEN}

1- The experts for the purpose of the provisions of clause 1 of Article 176 of this Code shall be a surveyor, a worker of land registry, an expert of land improvements, an architect, a civil engineer and a neighbor.

2- Experts for the purpose of the rule contained in clause 2 of Article 176 of this Code shall be an accountant, controller, professional technicians and skilled individuals.

\section{ARTICLE ONE HUNDRED SEVENTY-EIGHT}

If the identity of the plaintiff or the defendant is in doubt, the court can seek clarifications from the informed neighbors, class representatives or the head of the concerned office about his/her name, identity, occupation and place of residence.

\section{ARTICLE ONE HUNDRED SEVENTY-NINE}

1- If determining the age of persons, especially of women and children, is considered important during the trial proceedings and the persons do not possess citizenship document or, if there is a difference between his/her age as recorded in the citizenship document and his/her appearance, the court shall demand the opinion of a judicial doctor or another doctor.

2- In cases where the determination of age based on the opinion of the judicial doctor or another doctor varies from the background of the case and the appearances of the person, the issue of age determination is referred to a medical panel of not less than three persons.

\section{ARTICLE ONE HUNDRED EIGHTY}

The court shall seek information about the husband's impotence or his having diseases that are difficult to cure from an expert gynecologist and, in the absence of an expert, from a doctor, nurse and local mid-wife.

\section{ARTICLE ONE HUNDRED EIGHTY-ONE}

The court in cases of separation for reason of defect of husband shall obtain information from a relevant expert or a medical board regarding proof of the defect or affliction with incurable diseases or diseases that are curable in the long term.

\section{ARTICLE ONE HUNDRED EIGHTY-TWO}


Avoidance and rejection of experts are subject to the general bases of avoidance and rejection of the rules contained in Chapter Four of Part Two of this Code.

\section{ARTICLE ONE HUNDRED EIGHTY-THREE}

The parties to a claim have the right, if justifiable grounds exist, to demand rejection of experts. The court within three days from the date of the request for rejection shall make a decision in the matter. In case the grounds for rejection appear to be justifiable, the experts cannot express an opinion in the matter again.

\section{ARTICLE ONE HUNDRED EIGHTY-FOUR}

In claims whose complexity is the result of accounting issues and of the examination of papers and documents, or if the complexity of the claims has originated from elsewhere, the court shall assign one of the members of the court or an expert to supervise the issue and to take actions thereafter.

\section{ARTICLE ONE HUNDRED EIGHTY-FIVE}

The experts shall in all cases present their opinions in written form to the court and those opinions are then read in the judicial sessions.

\section{ARTICLE ONE HUNDRED EIGHTY-SIX}

The experts after their opinions are read in the session can be subjected to questioning. This questioning is conducted first by the person who has been selected based on the request by $\mathrm{him} /$ her or by his/her legal representative and then by persons involved in the case and by the court.

\section{ARTICLE ONE HUNDRED EIGHTY-SEVEN}

In the absence of sufficient clarification or in case of non-completion of opinion the court can order the experts to give further explanations and conduct complementary examinations.

\section{ARTICLE ONE HUNDRED EIGHTY-EIGHT}

In case the court identifies the opinion of the expert or informed person as undocumented or in conflict with reality, it shall require a new opinion from him/her or shall submit the matter to another expert or informed person.

\section{ARTICLE ONE HUNDRED EIGHTY-NINE}

In situations where the expert attends the judicial session, the results of his statements and examinations are recorded in the book of judicial records.

\section{ARTICLE ONE HUNDRED NINETY}


The court shall not be restricted to the opinion of the expert or the informed person, but shall examine the given opinion like other grounds of proof. If the result of the examination by the court does not comply with the opinion of the expert, the court shall reflect the reasons for the rejection of that opinion in details in the decision.

\section{CHAPTER ELEVEN: MANAGEMENT OF PRELIMINARY PROCEEDINGS IN CIVIL CASES}

\section{ARTICLE ONE HUNDRED NINETY-ONE RE}

A civil case that is brought to the consideration of the president, deputy or judge of the court by the office of court documents pursuant to the rule of Article 18 of this Code shall be subject to the following considerations:

1- In courts where the number of original/permanent or support/temporary judges is more than three, the president or the deputy of the court shall assign two persons from among the judges for the purpose of preliminary study of the case and the papers are submitted without delay by the office of the court documents to the assigned judicial panel.

2- In the city, district, sub-district and municipal courts in which the number of judges is less than three persons, the judges or the existing judge can conduct the preliminary study of the incoming cases and make a decision in the matter.

\section{ARTICLE ONE HUNDRED NINETY-TWO}

In case the proceedings of a civil case would require fixing of a price, limiting or determining the size, cleaning up or identification of other important situations in the subject matter of the claim, the court shall proceed according to the rules of Chapter Two of Part Two of this Code.

\section{ARTICLE ONE HUNDRED NINETY-THREE}

While conducting examination of the situations related to the subject of the claim, if the court finds either directly or as a result of oral statements of the parties that the discovery of the actual aspects of the case and the just proceedings of the case on its merit require the analysis of some other issues, the court shall issue a judicial ruling based on the analysis of the specific issues and shall proceed according to the rules contained in Articles 179-182 of this Code.

\section{ARTICLE ONE HUNDRED NINETY-FOUR}

If the court feels a need for the discovery of some special situations related to civil cases, it can assure itself of the statements and reasons of both sides and it can otherwise seek information in the matter from concerned authorities.

\section{ARTICLE ONE HUNDRED NINETY-FIVE}


The office of the court documents is obligated to present the background information regarding the case to the judicial panel after receipt of information contained in Article 192 to Article 194 of this Code.

\section{ARTICLE ONE HUNDRED NINETY-SIX}

The court cannot without justifiable need return the papers related to civil cases.

\section{ARTICLE ONE HUNDRED NINETY-SEVEN}

The court cannot without justifiable need postpone the proceedings and hearing of civil cases.

\section{ARTICLE ONE HUNDRED NINETY-EIGHT}

Issuance of a judicial ruling on the merits of civil cases is not allowed, except in situations where the law has provided otherwise.

\section{ARTICLE ONE HUNDRED NINETY-NINE}

The presidents of the tribunals of the Supreme Court, presidents of the courts, deputies, presidents of the tribunals of provincial courts, and the main district, city, district, sub-district and municipal courts are obligated to prepare the contents of civil cases with the explanation of the type of claim and the identity of the parties and to take relevant actions based on them.

\section{ARTICLE TWO HUNDRED}

The completion of trial stages in civil cases, including the follow-up by the parties to the claim, and the issuance of judicial ruling to the effect take place at most within four months.

\section{ARTICLE TWO HUNDRED ONE}

The time period contained in Article 200 of this Code is extendable according to the specific nature of some of the cases based on documented and justifiable reasons.

\section{ARTICLE TWO HUNDRED TWO}

The beginning of the period of judicial proceedings is valid after the plaintiff's claim is recorded on its special form.

\section{ARTICLE TWO HUNDRED THREE}

Differentiation of the plaintiff from the defendant and the separation outside of real possessor (zulyad) takes place at first instance by a judicial ruling. (not clear) 


\section{CHAPTER TWELVE: \\ THE TRIAL PROCEEDING AND PRESENCE OF INDIVIDUALS INVOLVED IN THE CASE}

\section{ARTICLE TWO HUNDRED FOUR}

It is obligatory that the plaintiff and the defendant or their proxy, guardian, executor or custodian appear before the court with the relevant documents.

\section{ARTICLE TWO HUNDRED FIVE}

In addition to the parties to the claim and the civil prosecutor, representatives of the governmental bureaus, organizations and third parties can participate in the judicial proceedings.

\section{ARTICLE TWO HUNDRED SIX}

The power of attorney is valid until the issuance of the decision by the court in which the claim is being heard. The following situations are exempt from this rule:

If it is clearly stated in the power of attorney document that the authority of making a demand, making an objection to the judgment and retrial, presenting and following up of the claim to the highest courts has been assigned to the representative.

\section{ARTICLE TWO HUNDRED SEVEN}

Judges and administrative workers of the courts cannot perform the duty of representation, except in cases where the claim in question concerns their husband, wife, father, grandfather, mother, grandmother, son and daughter.

\section{ARTICLE TWO HUNDRED EIGHT}

Judges and workers of the courts can act in their own claim in their own behalf and in the claim of the persons mentioned in Article 207 of this Code as representative, guardian, executor and custodian.

\section{ARTICLE TWO HUNDRED NINE}

The parties to the claim are guided to the court chamber in turn and their situations are examined in the following order:

1- The court makes a determination as to which one of them has appeared in the court as the principal, and which of them as proxy, guardian, executor and custodian.

2- The persons who appear in the court as deputies or representatives, the court workers shall file the document of their authority. 
3- The request of the plaintiff and all the documents and papers of the parties are regulated by the office of court document.

\section{ARTICLE TWO HUNDRED TEN}

The plaintiff shall present its petition in two copies. In case of inaccuracy of the claim, the plaintiff is obligated to correct the claim.

\section{ARTICLE TWO HUNDRED ELEVEN}

If the claim is accurate and the provisions of Article 26 of this Code are complied with, the defendant is obligated to present its written response to the court within specified time period.

\section{ARTICLE TWO HUNDRED TWELVE}

The court after the presentation of the written response by the defendant shall convey the date of the trial proceedings to the parties to the claim.

\section{ARTICLE TWO HUNDRED THIRTEEN}

If the parties to the claim appear in the judicial proceedings on the specified date, the proceedings shall be officially announced and the following steps shall be taken:

1- Following the claim of the plaintiff, the written defense by the defendant is recorded in a special form (a pleading form) and then the claim of the plaintiff and the defense of the defendant are read in the presence of the parties in the judicial session and the contents of the claim and defense are conveyed to the parties.

2- After the reading of the claim of the plaintiff and defense of the defendant, first the plaintiff is given time to explain the claim and the relevant documents, secondly, the defendant is given time to explain its response to the plaintiff's claim with presentation of documents.

3- The president of the session and members of the judicial panel shall question the parties about the lack of clarity and conflict.

4- The secretary of the session is obligated, following an order by the president of the court, to record the proceedings and explanations of the manner of removal of vagueness and conflict in the claim of the plaintiff and the defense of the defendant, and at the end of the trial, to get the record signed by the parties to the claim and by the judicial panel.

\section{ARTICLE TWO HUNDRED FOURTEEN}

The full presence of the judicial panel during the judicial negotiations and sessions is necessary. In the absence of the president of the session or one of the members of the judicial panel the session cannot be held. 


\section{ARTICLE TWO HUNDRED FIFTEEN}

The presentation of a witness to the possession of the immoveable subject matter of the claim is obligatory after the (proof of) accuracy of the claim.

\section{ARTICLE TWO HUNDRED SIXTEEN}

If during the trial one of the parties to the claim present as proof documents which are not part of the previously studied court papers, the court cannot accept those papers except in the following situations:

1- The court is satisfied that delivery of the mentioned papers was not possible at that time.

2- Existence of another reasonable excuse based on non-presentation of the mentioned papers at that time.

\section{ARTICLE TWO HUNDRED SEVENTEEN}

If any of the situations stated under Article 216 of this Code is applicable, the court shall assign another judicial session for the purpose of consideration of the issue.

\section{ARTICLE TWO HUNDRED EIGHTEEN}

The parties to the claim can resort to amending, changing, reducing, or increasing the claim and responses that they have submitted to the court separately within the copies only one time, on the condition that the said amendment does not change the merits of the claim and the defense in terms of quality or quantity.

\section{ARTICLE TWO HUNDRED NINETEEN}

The parties to the claim cannot demand from the court separate decisions regarding each part of their claims, defenses and objections that have been contained in one claim.

\section{ARTICLE TWO HUNDRED TWENTY}

If the proceedings and the trial and the issuance of the judgment do not occur in one session, another date is assigned for the subsequent session and the parties are informed of this.

\section{ARTICLE TWO HUNDRED TWENTY-ONE}

If one of the parties to the claim dies during the trial, the heirs of the deceased is summoned to the court pursuant to the demand by the opposite side and the court restarts from the point it had stopped.

\section{ARTICLE TWO HUNDRED TWENTY-TWO}


If the plaintiff requests an additional time to prove its case, the court shall give it the necessary time.

\section{ARTICLE TWO HUNDRED TWENTY-THREE}

If a need arises during the trial for the papers and documents related to the claim of the plaintiff and the defense of the defendant and such documents exist in the mixed and confidential government offices and organizations, the court shall allow time for the purpose of obtaining such documents and papers.

\section{ARTICLE TWO HUNDRED TWENTY-FOUR}

If the arrival of papers by the parties to the claim is not possible, the court can officially demand the needed papers from relevant authorities.

\section{ARTICLE TWO HUNDRED TWENTY-FIVE}

If a party to the claim denies the contents of the papers and documents that are presented to the court for the purpose of proof of the claim or claims that they are forged, the issue shall be dealt with and the proceedings shall take place according to the provisions of Chapter 15 of this Part.

\section{ARTICLE TWO HUNDRED TWENTY-SIX}

A claim arising from the actual/original claim that is presented by the plaintiff or the defendant during the proceedings of the claim, the court shall deal with the incidental claim during the actual/original claim and make a decision regarding it.

\section{ARTICLE TWO HUNDRED TWENTY-SEVEN}

The court shall issue a judicial ruling regarding an emerging claim that requires urgent hearing.

\section{ARTICLE TWO HUNDRED TWENTY-EIGHT}

If the emerging claim resulting from the actual claim is raised in the superior courts, it shall be returned to the initial court.

\section{ARTICLE TWO HUNDRED TWENTY-NINE}

The emerging claim does not require passage through the preliminary steps.

\section{ARTICLE TWO HUNDRED THIRTY}

The court shall recommend the assignment of conciliators in cases where the court senses willingness on the part of the parties for settlement.

\section{ARTICLE TWO HUNDRED THIRTY-ONE}


1- If the parties to the claim settle their differences prior to the commencement of the claim and the proceedings, their settlement is put in writing and their dispute is brought to an end.

2- If the settlement takes effect during the proceedings and the trial, the settlement is recorded in the decision and a judgment is issued allowing the settlement and an end to the dispute between the parties.

\section{ARTICLE TWO HUNDRED THIRTY-TWO}

If the parties do not agree to settle (their dispute), the court shall proceed with the matter and shall issue a decision accordingly.

\section{ARTICLE TWO HUNDRED THIRTY-THREE}

During the proceedings the office of court documents is obligated to observe the following steps and record them in the presence (of the court):

1- Name of the presiding judge and judicial panel, identity of the parties to the claim and name of the interpreter, if one exists.

2- Statements of the parties.

3- Name of the witnesses with their full identities.

4- Summary of the contents of the documents that the parties present.

5- Scrutinies that are performed by the court.

6- The decision that is taken by the court.

\section{ARTICLE TWO HUNDRED THIRTY-FOUR}

If the trial is not ended and the proceedings are postponed to next day, the judicial proceedings during the followings days are recorded and performed in the order provided for under Article 233.

\section{ARTICLE TWO HUNDRED THIRTY-FIVE}

Minutes (of the proceedings) and other papers and documents to be kept in the court together with the background materials of the case.

\section{ARTICLE TWO HUNDRED THIRTY-SIX}

After the investigation and scrutiny of the case and proceedings regarding the reasons, the presiding judge shall demand additional explanations from the parties. In case the parties do not 
have (further) explanations, the president of the court shall announce the end of the investigation of the case and shall proceed with judicial discussions.

\section{ARTICLE TWO HUNDRED THIRTY-SEVEN}

The judicial discussions contain statements involved in the case that take place in the following order:

1- Statements of the plaintiff or his/her legal representative.

2- Statements of the defendant or his/her legal representative.

3- Statements of a third person who presents a separate request during the proceedings of the case.

4- The opinion of the prosecutor involved.

5- Other issues that assists the speedy trial.

\section{ARTICLE TWO HUNDRED THIRTY-EIGHT}

The participants in the judicial discussions as provided for in Article 237 of this Code cannot bring as proof in their statements the situations and reasons that have not been explained to the court and have not been investigated in the judicial proceedings.

\section{ARTICLE TWO HUNDRED THIRTY-NINE}

If the claim has reached at the stage of issuance of judgment after following procedures, a change in the essence or in the attributes of the parties cannot prevent the issuance of a ruling.

A change in essence or substance means death and a change in attributes means the occurrence of insanity and bankruptcy.

\section{ARTICLE TWO HUNDRED FORTY}

The court shall accept the request of a third person for a right of demand, authority to intervene in the claim and presence in the trial.

If the legal stages of the judgment have come to an end, the announcement of the court's judgment to the parties cannot be postponed as a result of this request.

\section{ARTICLE TWO HUNDRED FORTY-ONE}

At the conclusion of the investigation and scrutiny, and after judicial discussions and statements by the parties to the effect that they have nothing else to say, the presiding judge shall announce the end of the trial to the parties. 


\section{ARTICLE TWO HUNDRED FORTY-TWO}

After the announcement and the end of the trial the right of the parties to give statements ends.

\section{ARTICLE TWO HUNDRED FORTY-THREE}

After the end of the trial, the judicial panel enters the chamber of the judicial consultations for the purpose of making a decision and arrangement of the text of the judgment, and before that the issue is announced to those attending the judicial proceedings by the president of the session.

\section{ARTICLE TWO HUNDRED FORTY-FOUR}

After a decision has been taken and the text of the judicial panel has been arranged, a reference is made to the chamber of the, the president of the session shall announce the court's judgment, explain the time period for complaints and appeals.

\section{ARTICLE TWO HUNDRED FORTY-FIVE}

If the session has been held in the office of the judicial panel, those present in the session shall step out of the session simultaneously with the announcement of the end of the trial, and after the decision is taken the parties to the claim are allowed to enter the session so that the judgment is announced to them.

\section{CHAPTER THIRTEEN: DECISION AND JUDGMENT OF THE COURT}

\section{ARTICLE TWO HUNDRED FORTY-SIX}

The decisions of the judicial panel on merits or substance of the claim are issued in the form of a judgment.

\section{ARTICLE TWO HUNDRED FORTY-SEVEN}

The decision of the court shall be legal and documented.

\section{ARTICLE TWO HUNDRED FORTY-EIGHT}

The court issues its decision only on the basis of the evidence that have been gathered and investigated during the judicial proceedings.

\section{ARTICLE TWO HUNDRED FORTY-NINE}

While issuing the judgment in the consultations chamber only the relevant judicial panel can be present and the presence of others is not allowed.

\section{ARTICLE TWO HUNDRED FIFTY}


The judgment of the court shall be issued with the majority opinion of the judicial panel in such order that first the members and then the president shall express their opinions. No member of the judicial panel has the right to decline from giving an opinion.

\section{ARTICLE TWO HUNDRED FIFTY-ONE}

If one of the members of the judicial panel does not agree with the opinion of the majority, he/she shall write his/her specific opinion in a separate paper and after the signature and seal attach it to the decision. This opinion is not read in the judicial proceedings.

\section{ARTICLE TWO HUNDRED FIFTY-TWO}

It is not allowed to disclose opinions that are expressed by the judges in the consultations room.

\section{ARTICLE TWO HUNDRED FIFTY-THREE}

The decision is written by the presiding judge or one of the judges participating in the issuance of the judgment and is then sealed and signed by the judicial panel.

\section{ARTICLE TWO HUNDRED FIFTY-FOUR}

The decision consists of the introduction, description, reasoning, conclusion and the text of the judgment.

\section{ARTICLE TWO HUNDRED FIFTY-FIVE}

The introductory part of the decision consists of the following issues:

1- The name of the setting court, name of the president of the session, judicial members, secretary of the session and the prosecutor, if he is a participant in the session.

2- The full introduction of the plaintiff and defendant with the explanation of residence, occupation, duty, place of occupation and work, the citizenship document's number and its place of issue, the introduction of other individuals involved in the case, their attorneys and legal representatives.

3- The identification of the type of subject matter of the claim.

4- Number, date and place of issue of the decision, date of announcement, number of sheets of the decision and its annexes.

\section{ARTICLE TWO HUNDRED FIFTY-SIX}

The descriptive part of the decision consists of the following: 
1- The facts of the plaintiff's case, the defenses of the defendant and other demands by the parties to the claim.

2- Confession or denial.

3- Testimony of witnesses, its acceptance or rejection.

4- Documents, absolute evidence and circumstantial evidence.

5- Oath or retraction.

6- A summary of the trial proceedings.

\section{ARTICLE TWO HUNDRED FIFTY-SEVEN}

The reasoning part of the decision consists of the following:

1- The investigative part of the case in the court.

2- The means of proof or rejection and explanation of reasons.

3- The reasoning that the court accepts or rejects based on the reasons presented.

\section{ARTICLE TWO HUNDRED FIFTY-EIGHT}

The conclusion part of the decision consists of the following:

1- Non-existence of proof for the claim

2-..... of the defendant.

3- The size of restitution or damages related to the subject of the judgment.

4- The expense of the court.

\section{ARTICLE TWO HUNDRED FIFTY-NINE}

The text of the judgment (ratio decidendi) consists of the following:

1- Mention of the date of the judicial session and the issuance of the judgment with a majority of opinion or with a consensus.

2- Reliance on specific reasons with the mention of the article of law.

3- Mention of the parties to the claim. 
4- Determination of the subject of the judgment.

5- Dismissal of the claim.

6- Abandoning of the claim.

7- Non-existence of proof of the claim.

8- Obligation of the defendant.

\section{ARTICLE TWO HUNDRED SIXTY}

The text of the judgment must be clear and clear of any type of verbal and mental limitation.

\section{ARTICLE TWO HUNDRED SIXTY-ONE}

1- The court's judgment shall be announced to the parties to the claim without delay after the conclusion of the trial.

2- The decision of the court shall be organized, prepared and issued within ten days.

\section{ARTICLE TWO HUNDRED SIXTY-TWO}

The judicial panel cannot amend or cancel its decision after the announcement of the judgment in the case.

\section{ARTICLE TWO HUNDRED SIXTY-THREE}

The court can in any case correct the typing errors, grammatical errors and numerical errors in the decision. The judicial panel shall correct the mistakes and errors in the decision and sign underneath it.

\section{ARTICLE TWO HUNDRED SIXTY-FOUR}

If there is vagueness in the judgment or decision, the court shall, pursuant to the request by the individuals involved in the case, get the judicial panel to explain the vagueness in the judicial session on the condition that the decision has not yet been implemented.

\section{ARTICLE TWO HUNDRED SIXTY-FIVE}

In case the implementation of final decision requires monetary payment, the court can pursuant to the request of individuals involved in the case and by taking into consideration the determination of the state of wealth of the convicted person or other conditions, prescribe in the text of the judgment that payment be made in installments.

\section{ARTICLE TWO HUNDRED SIXTY-SIX}


The decision of the court becomes absolute in the following situations:

1- The expiry of the time period allowed for complaints without legal excuse.

2- Presentation of complaints or objection to the higher court, in case in the proceedings of the case in the higher court a decision of cancellation is not made.

\section{CHAPTER FOURTEEN: \\ RULING OF THE COURT}

\section{ARTICLE TWO HUNDRED SIXTY-SEVEN}

The ruling of the court is a judicial decision that is not issued on the merits of the claim but rather in relation to the procedures.

\section{ARTICLE TWO HUNDRED SIXTY-EIGHT}

The ruling of the court is issued by the judicial panel in the consultation room according to the provisions of Article 243 of this Code.

\section{ARTICLE TWO HUNDRED SIXTY-NINE}

The court can after consultation with the judicial panel issue a ruling regarding ordinary matters without compliance with the provisions of Article 268 of this Code and record the ruling in the minutes of the court.

\section{ARTICLE TWO HUNDRED SEVENTY}

The ruling of the court is announced upon issuance.

\section{ARTICLE TWO HUNDRED SEVENTY-ONE}

The ruling of the court consists of the following:

1- The date and place of the ruling's issuance.

2- The name of the court issuing the ruling, composition of the court and the secretary of the judicial session.

3- Individuals involved in the claim of an issue at dispute.

4- The issue about which a ruling is issued.

5- Reasons and grounds upon which the court has issued its ruling.

6- Legal reliance by the court. 
7- Coming to a conclusion and taking a decision by the judicial panel.

8- Specifying the time period for complaints against a ruling that is not legally absolute.

9- Mention of the ruling being absolute in situations where the ruling has been considered final according to the provisions of the law.

\section{CHAPTER FIFTEEN: \\ GROUNDS OF JUDGMENT (EVIDENTIARY TOOLS) \\ ARTICLE TWO HUNDRED SEVENTY-TWO}

The means of proof that form the grounds of judgment are as follows:

1- Confession.

2- Evidence (documents, witnesses, absolute evidence and circumstantial evidence)

3- Oath (swearing)

4- Retraction

\section{ARTICLE TWO HUNDRED SEVENTY-THREE}

Confession means information about an issue in the court that proves continuation of the right of the party to the claim or which proves the condition against the person making confession.

\section{ARTICLE TWO HUNDRED SEVENTY-FOUR}

The confession of the person making it who is legally competent in the eyes of the court is valid if the apparent conditions do not render it untrue.

\section{ARTICLE TWO HUNDRED SEVENTY-FIVE}

The confession by the person making it is not conditioned upon acceptance by the person to whom the confession is made, but its rejection can take place by the person to whom the confession is made. If a part of the confession is rejected by the person to whom it is made, the remainder of the confession stands true.

\section{ARTICLE TWO HUNDRED SEVENTY-SIX}

Confession as to an absentee person's right is not valid until the time of notice to and confirmation by the absentee of the confession of the person making it.

\section{ARTICLE TWO HUNDRED SEVENTY-SEVEN}


Retracting a confession that has been made according to the provisions of Article 273 of this Code is not valid.

\section{ARTICLE TWO HUNDRED SEVENTY-EIGHT}

Confession regarding joint share that has not been separated is correct.

\section{ARTICLE TWO HUNDRED SEVENTY-NINE}

If the defendant confesses in front of the court to the claim of the plaintiff, he shall be considered culpable.

\section{ARTICLE TWO HUNDRED EIGHTY}

If the defendant denies (the claim) the burden of proving the claim shall be upon the plaintiff.

\section{ARTICLE TWO HUNDRED EIGHTY-ONE}

The sources of proof are as follows:

1- Documents.

2- Testimony of witnesses.

3- Evidences

\section{ARTICLE TWO HUNDRED EIGHTY-TWO}

Documents are of two types:

1- Official documents.

2- Customary documents.

\section{ARTICLE TWO HUNDRED EIGHTY-THREE}

Official and customary documents are those that have been described in clauses 1 and 2 of Article 991 of the Civil Code.

\section{ARTICLE TWO HUNDRED EIGHTY-FOUR}

Official documents regarding confessor, heirs and their alternates are valid and binding prior to the commencement of the claim.

\section{ARTICLE TWO HUNDRED EIGHTY-FIVE}


The person who has been accepted as witness of identity in the official documents and if he/she claims the ownership that is contained in the document, the said official document shall be binding on him/her before the commencement of the claim.

\section{ARTICLE TWO HUNDRED EIGHTY-SIX}

The claim of the plaintiff against official documents is invalidated by the presentation of invalidating document by the defendant or it shall be proven by the confession of the defendant.

\section{ARTICLE TWO HUNDRED EIGHTY-SEVEN}

Edicts, official documents, absolute decisions and rulings of the court, if they are clear of forgery and falsification, and if they have been safely recorded in the government office of a judicial tribunal, such documents are recognized as bases of proof and they shall be binding.

\section{ARTICLE TWO HUNDRED EIGHTY-EIGHT}

The official documents in whose ordering and arrangement the provisions of the law have not been complied with have the status of customary documents.

\section{ARTICLE TWO HUNDRED EIGHTY-NINE}

The customary documents that have been written and signed by the parties and their seal or fingerprinted have been placed on them, and in case the two sides confirm their seal, signature and fingerprint, such documents are of the same validity as the official documents.

\section{ARTICLE TWO HUNDRED NINETY}

The customary document that has been written and signed in personal hand-writing of a person and, in case his writing and signature is confirmed by a hand-writing expert, such customary document shall have the same validity as an official document.

\section{ARTICLE TWO HUNDRED NINETY-ONE}

The persons under whose seal, signature or fingerprint customary documents are presented in a dispute are obligated to confirm or deny their seal, signature or fingerprint. Their silence is considered denial.

\section{ARTICLE TWO HUNDRED NINETY-TWO}

A legator cannot be forced to confirm or deny the seal, signature or fingerprint of his legatee. He only has the right of confession, denial or profession of ignorance.

\section{ARTICLE TWO HUNDRED NINETY-THREE}


Minute correspondences, telegram and other signed papers belonging to offices that exist in the relevant office have the status of customary documents.

\section{ARTICLE TWO HUNDRED NINETY-FOUR}

Recording the testimony of two witnesses of identity who have the capacity to give testimony are mandatory in all courts security documents. Persons known to the court are exempt from this rule.

\section{ARTICLE TWO HUNDRED NINETY-FIVE}

If there are numerous legators and partners and if some of them have prepared the security document, this document is valid only in regards to those who have prepared it and cannot involve the remaining legators and partners.

\section{ARTICLE TWO HUNDRED NINETY-SIX}

1- The judge cannot prepare in a court where he/she performs his/her duties a security document for himself, his father, grandfather, mother, grandmother, children, brother, sister and for workers of the relevant court.

2- Acceptance by the judge of persons contained in clause 1 of this Article as witnesses, experts or interpreter is not allowed.

\section{ARTICLE TWO HUNDRED NINETY-SEVEN}

The security documents of the persons mentioned in Article 296 of this Code is prepared in the neighboring court.

\section{ARTICLE TWO HUNDRED NINETY-EIGHT}

The supervision of requests based on dubiousness and forgery of the official documents belongs to the authorized preliminary court.

\section{ARTICLE TWO HUNDRED NINETY-NINE}

If requests regarding doubtfulness, forgery or falsification of documents are presented to other authorities, such requests are returned to the relevant sub-district, municipal, city or district courts.

\section{ARTICLE THREE HUNDRED}

If the claim regarding doubt and forgery in the documents requires proof, the criminal pursuit of the issue is postponed until the final proceedings regarding right of servitude.

\section{ARTICLE THREE HUNDRED ONE}


If the court after evaluating the reasons considers the claim of suspiciousness and forgery as baseless, it shall issue a ruling dismissing the claim. This ruling can be appealed against.

\section{ARTICLE THREE HUNDRED TWO}

If the court after evaluation of reasons, consider the claim of suspiciousness and forgery as valid, it shall issue a ruling for the proceedings of claim of suspiciousness and forgery and convey it to the plaintiff to present his/her claim papers.

\section{ARTICLE THREE HUNDRED THREE}

1- If on the face of it, a submitted document of one of the parties to the claim appears doubtful in the eyes of the court, the court can officially demand a copy of it from the place that has prepared it.

2- The rule of clause 1 of this Article is also applicable in case of a suspicion in the confirmation presented.

\section{ARTICLE THREE HUNDRED FOUR}

1- The protrusions and sentences that have been written between the lines or in the margins are not valid.

2- In case the additions contained in clause 1 of this Article have been confirmed and signed by the person who confesses, the person to whom the confession is made and the witnesses and they have been signed and sealed by the person preparing them, they shall be valid.

\section{ARTICLE THREE HUNDRED FIVE}

Statements by the creditor on the front and back of a document in the hands of the debtor indicating whether the whole or part of the debt has been paid is valid only when the creditor admits their accuracy or if they have been written and signed in his handwriting.

\section{ARTICLE THREE HUNDRED SIX}

The party whose original document is detained by the official authorities and despite the need to present the document to the court it cannot do so for justifiable reasons, in that case, it can demand the original document through the court. The expenses arising from this demand are born by the owner of the document.

\section{ARTICLE THREE HUNDRED SEVEN}

The documents that have been prepared outside the country can be valid only when the said document has been prepared and signed by one of the political missions of the Republic of Afghanistan and the Foreign Ministry has also officially assured of its accuracy. 


\section{ARTICLE THREE HUNDRED EIGHT}

If resort is made to a document that has been prepared in a foreign language, the person resorting to such a document is obligated to present the original document simultaneously with its certified translation to the court. If the translation of the document is not accepted by the opposing party or by the court, a new translation of the document is made by the court at the expense of the person presenting it. In case of conformity of the second translation with the first translation the right of the return of the party harmed to the opposite side is not jeopardized.

\section{ARTICLE THREE HUNDRED NINE}

If the claims of suspiciousness and forgery of the submitted documents arise during the proceedings of the court, its manner is recorded in the special claim form and the signature and fingerprint of the person making the claim are placed underneath it.

\section{ARTICLE THREE HUNDRED TEN}

1- If the document subject to the claim of suspicion or forgery is not material to the claim, it shall not be valid with the court and the court shall hear other evidences and documents of the plaintiff.

2- If the document subject to the claim of suspicion or forgery is material to the claim, the court shall issue a ruling for commencement of proceedings concerning the claim of suspicion or forgery and shall suspend the original claim under proceedings until the passage of final stages.

\section{ARTICLE THREE HUNDRED ELEVEN}

The person claiming suspiciousness and forgery is obligated to pursue his/her claim in the authorized court within one month.

\section{ARTICLE THREE HUNDRED TWELVE}

If the person claiming suspiciousness and forgery does not attend his/her own claim without justifiable reason at the time specified in Article 311 of this Code, the court shall specify and announce another date for the appearance of the claimant. In case the claimant still does not pursue the claim of suspiciousness and forgery during the specified time there shall be no further time specified for his/her claim of suspiciousness and forgery, the court shall then summon the parties and proceed with the actual/original claim already under proceedings.

\section{ARTICLE THREE HUNDRED THIRTEEN}

If the proceedings regarding the claim of forgery is also taken up by a court other than the court authorized to hear the original claim, the court proceeding with the claim of forgery is obligated to inform from time to time the court that hears the original claim of the result of its proceedings.

\section{ARTICLE THREE HUNDRED FOURTEEN}


Compliance with the following points is necessary in proceedings related to suspicious and forged documents:

1- Close attention to the hand-writing.

2- Close attention to the signature.

3- Close attention to the seal.

4- Close attention to the fingerprint.

5- Clearing and erasure and re-writing without correction.

6- Protrusion without seal and signature.

7- Photos of those included in the security document.

8- Difference in the original and the record of the security document.

\section{ARTICLE THREE HUNDRED FIFTEEN}

The manner of proceeding with the claim of suspiciousness and forgery is regulated in addition to the rules that are provided in this Code by a separate bill in which the writing of the instruments and mistake of the instruments are explained and the high council of the Supreme Court approves it.

\section{ARTICLE THREE HUNDRED SIXTEEN}

Appeal in the civil and public interest cases that are raised in relation to the suspiciousness of instruments of exoneration and settlement or in relation to decisions regarding confession, exoneration and settlement are valid from the date of presentation of the claim of suspiciousness and forgery, and not from the date of the issue of the original instrument or decision.

\section{ARTICLE THREE HUNDRED SEVENTEEN}

The superior court shall evaluate the instruments and decisions contained in Article 316 of this Code from the point of view of suspiciousness or forgery and their reasons, and in case suspiciousness and forgery did not exist, it shall issue a judgment approving them.

\section{ARTICLE THREE HUNDRED EIGHTEEN}

If the judgment of the (lower) court has been issued based on a confession, settlement, exoneration or in reliance upon instruments and official documents being duly recorded in the justice tribunal and if there has not been a claim of forgery and suspiciousness regarding the mentioned documents, the superior court shall dismiss an appeal against such a judgment. 


\section{ARTICLE THREE HUNDRED NINETEEN}

The court cannot give to individuals the duplicate of the documents about which a claim of suspiciousness or forgery has been made.

\section{ARTICLE THREE HUNDRED TWENTY}

If the court issues an absolute decision stipulating that a document is forged, a summary of the judgment of nullity to that effect shall be written underneath the original and the stub of the (forged) document and the special seal of the president of the court shall be placed on it.

\section{ARTICLE THREE HUNDRED TWENTY-ONE}

1 - Testimony of witnesses means giving information as to the truth in the judicial session with the wording of "I swear".

2- The court is obligated to emphatically comply with the conditions of testimony of the witnesses.

3- From the point of view of the strength of proof, testimony is placed in the second place.

4- The amount of testimony and its conditions are subject to the rules of the Islamic law.

\section{ARTICLE THREE HUNDRED TWENTY-TWO}

The testimony of the witnesses is heard individually in the presence of the parties in the session of judicial panel.

\section{ARTICLE THREE HUNDRED TWENTY-THREE}

The court prior to hearing the testimony of the witnesses is obligated to clarify the full identity of the witnesses.

\section{ARTICLE THREE HUNDRED TWENTY-FOUR}

1- If the plaintiff introduces the full identity of witnesses in response to a query by the court prior to the statements of the witnesses in front of the judicial panel and the party to the claim, but at the time of appearance, the plaintiff brings other witnesses to the court, the court shall not accept those witnesses.

2- If the claimant brings the same witnesses whose full identities he has already introduced, the court shall allow those witnesses to give testimony.

\section{ARTICLE THREE HUNDRED TWENTY-FIVE}


If in the legal dealings one of the witnesses attends the proceedings on the specified day and another witness for justifiable reasons could not attend, the court shall hear the statements of the present witness and shall give time for the appearance of the absentee witness.

Witnesses in cases of punishment and retaliation are exempt from this rule.

\section{ARTICLE THREE HUNDRED TWENTY-SIX}

The testimony of witnesses in the judicial proceedings shall be recorded by a member of the judicial panel and is read in the presence of witnesses and parties to the claim and their signature, seal and fingerprint are placed on it.

\section{ARTICLE THREE HUNDRED TWENTY-SEVEN}

1- If the witnesses cannot give their testimony from memory due to the multiplicity of four borders and multitude of the subject matter of the claim, they shall can read their testimony from writing in the presence of the court panel and they can point at the appropriate time toward the plaintiff, defendant and the subject matter of the claim, as needed.

\section{ARTICLE THREE HUNDRED TWENTY-EIGHT}

If after bringing the witnesses the defendant confirms the testimony of the witnesses or admits the actual subject matter of the claim, the court shall issue its judgment in reliance upon that admission.

\section{ARTICLE THREE HUNDRED TWENTY-NINE}

The plaintiff is demanded to present its defense against the hostile testimony of witnesses to possession, and after possession is proven, the defended is demanded to present reason and evidence. If the defendant is unable to bring reason and evidence, the court shall make a judgment prohibiting and neutralizing the attack of the defendant against the subject matter of the claim.

\section{ARTICLE THREE HUNDRED THIRTY}

1- The court is authorized to specify, by having regard to the distance and manner of appearance, the time and duration for the presentation of witnesses.

2- The court shall allow the claimant/plaintiff three opportunities to bring witnesses.

\section{ARTICLE THREE HUNDRED THIRTY-ONE}

If the plaintiff expresses before the court that he/she would not be able to bring witnesses no matter how much time he/she is given, his/her statements to this effect shall be recorded in the claim form and underneath it his/her fingerprint and signature shall be placed. If the plaintiff then presents witnesses, they shall not be accepted. 


\section{ARTICLE THREE HUNDRED THIRTY-TWO}

If the witnesses as a result of the request by the plaintiff do not appear before the court willingly, the court can pursuant to the request of the plaintiff summon the witnesses.

\section{ARTICLE THREE HUNDRED THIRTY-THREE}

1- The quorum of consecutive witnesses for the purpose of proving the subject matter of the claim shall be less than 25 persons.

2- The test of character of the consecutive witnesses is not applicable whether conducted secretly or openly.

\section{ARTICLE THREE HUNDRED THIRTY-FOUR}

The testimony of witnesses is not valid outside the court.

\section{ARTICLE THREE HUNDRED THIRTY-FIVE}

The testimony of principal regarding proxy and vice-versa, of husband regarding wife and viceversa and of other relatives up to the second degree is not allowed.

\section{ARTICLE THREE HUNDRED THIRTY-SIX}

The testimony of a partner regarding partner in partnership, and of friend regarding friend in interest is not correct.

\section{ARTICLE THREE HUNDRED THIRTY-SEVEN}

1- Testing the character of obligated witnesses and the manner and conditions of the test are subject to the rules of Islamic law.

2- The Supreme Court is obligated to regulate and implement according to the rules of Islamic law the manner of performing secret or open test of character of the obligated witnesses.

\section{ARTICLE THREE HUNDRED THIRTY-EIGHT}

1- Absolute evidence is that based on whose indication an unclear matter becomes clear. This indication brings evidence to the level of certainty and such evidence can be used at its face value in regards to the actual subject of the dispute.

2- If a person observes the exercise of ownership by another person and does not claim ownership for himself despite the absence of legal excuses such as age of minority, insanity, etc., and then if he/she makes such a claim, his/her claim of ownership is negated based on the indication of absolute evidence. 


\section{ARTICLE THREE HUNDRED THIRTY-NINE}

1- Circumstantial evidence is that which the court infers from the circumstances of the claim and from the trial proceedings, and then the court relies on it as a basis for its judgment.

2- If there is clear legal text is not allowed, reliance on circumstantial evidence.

\section{ARTICLE THREE HUNDRED FORTY}

Oath and retraction of the oath:

If the plaintiff is unable to present in the court other means and sources of proof, he/she can direct the defendant to take an oath. In such a case, the court shall pursuant to the demand of the plaintiff administer an oath to the defendant.

\section{ARTICLE THREE HUNDRED FORTY-ONE}

If the defendant takes an oath in the court, the claim of the plaintiff is rejected and a judgment dismissing the current dispute is issued.

\section{ARTICLE THREE HUNDRED FORTY-TWO}

In case the claim contains numerous issues, reliance is made on a single oath.

\section{ARTICLE THREE HUNDRED FORTY-THREE}

Oath or retraction from oath in the court is valid (only) in the presence of the adversary or his/her substitute.

\section{ARTICLE THREE HUNDRED FORTY-FOUR}

Acceptance of the oath or retraction from the oath belongs to the person of the defendant. There is no effect from a refusal by an attorney to take an oath or from his retraction.

\section{ARTICLE THREE HUNDRED FORTY-FIVE}

If the plaintiff abandons his/her right to demand an oath, the court shall issue a judgment dismissing the plaintiff's claim.

\section{ARTICLE THREE HUNDRED FORTY-SIX}

If the defendant retracts his/her oath, the court shall oblige him to reject the subject matter of the claim or submit it to the plaintiff.

\section{ARTICLE THREE HUNDRED FORTY-SEVEN}


The defendant can resort to a proper defense against the claim of the plaintiff. The defense of the defendant is considered proper in the following situations:

1- The plaintiff has quit his/her claim.

2- The plaintiff has given the subject matter of the claim as a gift.

3- Has purchase the subject matter of the claim from the plaintiff.

4- Has performed what the plaintiff has demanded.

\section{ARTICLE THREE HUNDRED FORTY-EIGHT}

1- If the party claiming to have a defense is unable to prove his/her defense, he/she can demand the original plaintiff to take an oath.

2- If the claimant retracts from the claim of defense by the defendant, the claim of the original plaintiff is rejected and he/she becomes culpable.

\section{ARTICLE THREE HUNDRED FORTY-NINE}

If the plaintiff swears against the defendant's defense of gift, purchase and waiver, in such a case the defendant becomes culpable.

\section{ARTICLE THREE HUNDRED FIFTY}

A defense involving confession in the absence of proof renders the defendant culpable and obliges him/her to surrender the subject matter of the claim.

In case of a defense not involving confession, the proceedings of the case shall continue in the original manner.

\section{ARTICLE THREE HUNDRED FIFTY-ONE}

The claim of defense requires compliance with other legal requirements of claims.

\section{ARTICLE THREE HUNDRED FIFTY-TWO}

The court pursuant to the provisions of Articles 1022 to 1024 of the Civil Code shall without the demand by the adversary, directly administers the oath to the plaintiff. This oath is within the jurisdiction of the court and is complementary and it takes place in the following situations:

1- In a claim for entitlement where the subject matter of the claim is in the possession of another person and the person entitled to it claims a right to it, the court shall administer an oath to the claimant (of this right) regarding the following matters after the said right has been proven and before the issuance of a judgment: 
-- has not sold the subject matter of the claim to any body.

-- has not given the subject matter of the claim to someone as a gift or charity.

2- In a claim related to debt or right against a deceased, the court shall administer an oath regarding the following matter to the claimant after his/her right has been proven and before the issuance of a judgment:

-- The subject matter of the claim has not reached him/her (the plaintiff) either directly or indirectly.

3- In a claim of pre-emption, the court shall after the right of pre-emption has been proven and prior to the issuance of the judgment administer an oath to the person exercising the right of preemption regarding the following matters:

-- Has made timely demand for the right of pre-emption.

-- Has in no way abrogated his/her right of pre-emption.

4- In a claim related to the rejection of a purchased property for reason of defect, the court shall administer an oath to the claimant regarding the following matter after the defect has been proven and before the issuance of a judgment:

-- Has not shown acceptance of the defect whether expressly or by indication.

5- In a claim of (lack of maintenance, the court shall administer the following oath to the wife after the proof of right to maintenance and before the issuance of judgment:

-- The husband has not left any maintenance for her.

-- He has not divorced her.

\section{ARTICLE THREE HUNDRED FIFTY-THREE}

The court shall pursuant to a demand by the plaintiff administer an oath in the name of Allah to the defendant once without repetition.

\section{ARTICLE THREE HUNDRED FIFTY-FOUR}

In taking an oath, representation is not allowed.

\section{ARTICLE THREE HUNDRED FIFTY-FIVE}

In an issue related to an event and action that the person taking the oath has brought about an absolute oath is administered, and in an issue related to other event and action an oath of knowledge is administered. 


\section{ARTICLE THREE HUNDRED FIFTY-SIX}

In an issue related to the occurrence or non-occurrence of a matter an oath as to the reason and in an issue related to the continuation or non-continuation of the status quo an oath of occurrence is administered.

\section{ARTICLE THREE HUNDRED FIFTY-SEVEN}

In an issue related to the rejection of oath of the parties to each other, the rules contained in Section Four of Chapter One of Part Five of the Civil Code shall be complied with.

\section{PART THREE: \\ PROCEEDINGS IN SUPERIOR COURTS}

\section{CHAPTER ONE:} COMPLAINT AGAINST AND OBJECTION TO LOWER COURTS' DECISIONS

\section{ARTICLE THREE HUNDRED FIFTY-EIGHT}

Complaint and objection is the right of the convicted person who is not satisfied with the decision of the lower court which is demanded from the superior court by the presentation of a complaint against the judicial proceedings of the setting court.

\section{ARTICLE THREE HUNDRED FIFTY-NINE}

1- The convicted person who is not satisfied can bring a complaint and an objection in the higher court against the judgments issued by the setting municipal, city, district and sub-district courts.

2- The non-satisfied convicted person can bring a complaint and an objection in the tribunals of the Supreme Court against the issued judgments of the provincial courts that have issued judgment in a preliminary form.

\section{ARTICLE THREE HUNDRED SIXTY}

The civil prosecutor who participates in the case as a plaintiff or a defendant can object to the judgments of the lower courts.

\section{ARTICLE THREE HUNDRED SIXTY-ONE}

Complaint and objection against final judgments of lower courts shall take place in the following situations:

1- Mistake in the implementation of legal rules.

2- Mistake in the interpretation of the legal rules. 
3- Invalidity in the proceedings due to the issuance of an illegal judgment.

\section{ARTICLE THREE HUNDRED SIXTY-TWO}

The fundamental conditions for complaint and objection are as follows:

1- The decision of the lower court that possess the attribute of a judgment.

2- Non-satisfaction of the convicted person with the decision issued by the lower court.

3- Compliance with the legal time period for presentation of the objection.

4- Existence of jurisdiction by the upper court to proceed.

5- Non-existence of a separate document invalidating the right of the defendant to raise an objection.

6- Presentation of an objection by the plaintiff, defendant or their legal representative to the upper court.

7- Non-implementation and non-performance of the lower court's judgment to the satisfaction of the convicted person.

\section{ARTICLE THREE HUNDRED SIXTY-THREE}

Hearing the complaints against decisions of the city, municipal, district and sub-district courts shall be within the jurisdiction of the tribunals of the Supreme Court.

\section{ARTICLE THREE HUNDRED SIXTY-FOUR}

Hearing of complaints against the preliminary decisions of the tribunals related to the presidency of the provincial court or of an equivalent court shall be within the jurisdiction of the Supreme Court tribunals.

\section{ARTICLE THREE HUNDRED SIXTY-FIVE}

The time period to present complaint and objection after the issuance of the judgment and its announcement shall be one month.

\section{CHAPTER TWO: MANNER OF PRESENTATION OF COMPLAINT AND OBJECTION \\ ARTICLE THREE HUNDRED SIXTY-SIX}

The complaint by the non-satisfied culpable person against the decision of the lower court takes place in the form of a printed request letter. 


\section{ARTICLE THREE HUNDRED SIXTY-SEVEN}

The request letter containing the complaint shall be directly presented to the higher court or to the setting court.

\section{ARTICLE THREE HUNDRED SIXTY-EIGHT}

If the non-satisfied party mentions its non-satisfaction at the bottom of the paper containing the notice of the judgment that has been given to him by the city, municipal, district and sub-district courts, this shall be tantamount to making a complaint.

\section{ARTICLE THREE HUNDRED SIXTY-NINE}

The complaint letter of the non-satisfied party must contain the actual issue and the judgment of the lower court.

\section{ARTICLE THREE HUNDRED SEVENTY}

The request letter containing the complaint of the non-satisfied culpable person that is presented to the higher court or to the setting court shall be official and shall be recorded in the office of the court and the person making the complaint shall be given a receipt to this effect.

\section{ARTICLE THREE HUNDRED SEVENTY-ONE}

The complaint and objection that are presented after the expiry of the specified time period are not justiciable and are returned to those presenting them, unless the person making the complaint or objection can bring justifiable excuse.

\section{ARTICLE THREE HUNDRED SEVENTY-TWO}

The letter of complaint is signed by the person presenting it or his/her legal representative.

\section{ARTICLE THREE HUNDRED SEVENTY-THREE}

Objection of the prosecutor that is presented to the higher court shall be signed by the responsible prosecutor.

\section{ARTICLE THREE HUNDRED SEVENTY-FOUR}

If a complaint is presented by the legal representative, in addition to the number and date of the instrument recorded in the original letter of complaint, a photocopy or copy of the letter confirming the instruments is also presented to the higher court.

ARTICLE THREE HUNDRED SEVENTY-FIVE 
The higher court shall, after receipt of the complaint letters, officially requisition the papers related to the decision from the relevant authority.

\section{ARTICLE THREE HUNDRED SEVENTY-SIX}

The papers related to decision are submitted to the judicial panel upon arrival, and the judicial panel shall, after becoming aware of the fact that the complaint was presented in the specified time and that the papers are clear of administrative mistakes, order them to be recorded.

\section{ARTICLE THREE HUNDRED SEVENTY-SEVEN}

The detailed objection of the complainant shall be presented within twenty (20) days after the submission of the complaint.

\section{ARTICLE THREE HUNDRED SEVENTY-EIGHT}

Written complaint or detailed objection shall contain the following matters:

1- The name of the court to which the complaint or objection has been made.

2- The identity of the complainant.

3- Summary of the decision that is the subject of the complaint or objection.

4- The name of the court issuing the decision that is the subject of the complaint.

5- Reasons for inaccuracy of the decision.

6- Demand of the complainant or the person/party objecting.

7- Papers and documents containing the list of contents for the attachment of complaint or objection.

\section{ARTICLE THREE HUNDRED SEVENTY-NINE}

The complaint or objection contained in Article 378 of this Code is presented in two copies to the superior court.

\section{CHAPTER THREE: \\ PRELIMINARY PROCEEDINGS OF SUPERIOR COURT}

\section{ARTICLE THREE HUNDRED EIGHTY}

The office of the superior court's documents shall submit one copy of the written complaint or objection of the complainant after review and consideration by the judicial panel to the opposing party. 


\section{ARTICLE THREE HUNDRED EIGHTY-ONE}

1- If the complainant refuses to present a detailed written objection or express his/her excuse regarding his/her inability to present the objection, the court shall rely on his/her oral reasons and shall place his/her signature and fingerprint underneath his/her statements.

2- The rule of clause 1 of this Article is also applicable to the party opposing the party making the complaint.

\section{ARTICLE THREE HUNDRED EIGHTY-TWO}

The higher court shall issue a ruling regarding the postponement of the proceedings related to the complaint in the following situations and shall give to the complainant or the party making the objection time to correct the complaint or objection.

1- In case the complaint or objection has not been signed by those presenting them.

2- In case the necessary attachments have not been presented to the court together with the complaint.

3- In case the government duties related to the complaint or objection have not been paid.

\section{ARTICLE THREE HUNDRED EIGHTY-THREE}

The time period for submission of the complaint or objection is calculated from the date of their submission to the court, on the condition that the party presenting them perform the instructions contained in Article 382 within the specified time period.

\section{ARTICLE THREE HUNDRED EIGHTY-FOUR}

The complainant can abandon its complaint on the condition that this decision has not been subjected to a complaint or objection by a third person/party. In this case, the court shall make a ruling dismissing the complaint or objection and shall end the proceedings in this regard.

\section{ARTICLE THREE HUNDRED EIGHTY-FIVE}

1- The case containing the complaint and objection shall after statements of the parties with the objection of the prosecutor and response of the parties be submitted to the judicial panel for completion of studies.

2- After completion of the studies by the judicial panel the case shall be recorded in the agenda, and the venue of the proceedings for the complaint and the place of holding of the judicial session shall be announced to the parties to the claim and to the persons making the complaint in the case.

\section{ARTICLE THREE HUNDRED EIGHTY-SIX}


If the parties agree to settle at the final stage after submission of complaint or objection, this agreement shall be submitted in written form to the court, and in case the higher court approves of it, the court shall make a decision to end the proceedings.

\section{CHAPTER FOUR: \\ HOLDING OF JUDICIAL SESSION TO HEAR THE COMPLAINT AND OBJECTION}

\section{ARTICLE THREE HUNDRED EIGHTY-SEVEN}

The presiding judge shall at the stage of proceeding with the complaint and objection and by taking the provisions of Chapter thee of Part Two of this Code take necessary action to ensure the order in the judicial session.

\section{ARTICLE THREE HUNDRED EIGHTY-EIGHT}

The presiding judge shall after the opening of the session and introduction of the composition of the judicial panel and the civil prosecutor announce the following matters for the purpose of the proceedings:

-- Type of the case to be heard.

-- Introduction of the complainant or the person/party objecting.

-- Introduction of the court against whose decision the objection has been made.

The identity of the parties to the complaint is recorded in this session by the secretary of the session.

\section{ARTICLE THREE HUNDRED EIGHTY-NINE}

If one of the parties involved in the case is absent and this absence has been because of lack of information regarding the date and place of the proceedings of the case, the court shall order the postponement of the proceedings.

\section{ARTICLE THREE HUNDRED NINETY}

1- The absence of one of the parties involved in the case despite having information regarding the date and place of the proceedings of the case shall not obstruct the proceedings.

2- If the court considers the absence to be justifiable, it can postpone the proceedings of the case.

\section{ARTICLE THREE HUNDRED NINETY-ONE}

1- The court shall inform higher prosecutor or the association of defense attorneys of the unjustifiable absence of the prosecutor or the defense attorney from the hearing session. 
2- If the defense attorney after being summoned by the court does not appear in the judicial session within ten days, the court shall officially inform the association of the board of the defense attorneys of his/her absence that has been the reason for the postponement of the proceedings of the case.

\section{ARTICLE THREE HUNDRED NINETY-TWO}

1- The proceedings of the case at the appeal stage commences by a reading conducted by the head of the session or one of the judges of a report based on the study of the prepared papers.

2- The report describes the manner of the case, the judgment of the lower court, grounds for complaint, objection and other matters that have been newly presented to the court, and it also contains the sources that the court deals with for the purpose of controlling the accuracy of the decision.

\section{ARTICLE THREE HUNDRED NINETY-THREE}

1- The higher court shall while proceedings of a case having regard to the existing reasons and the reasons that have been presented by the parties or others involved in the case evaluate if the decision of the lower court has been legal and whether it has been documented by evidence in sections where complaint has been made and in the sections where there are no complaints against them and also in relation to individuals who have submitted complaints.

2- The court in the all-inclusive evaluation of the case shall not be bound by the reasons for the complaint and objection, and it only uses them as a means of the proceedings.

\section{ARTICLE THREE HUNDRED NINETY-FOUR}

The judicial panel shall, after the case is reported, hear the explanations of the parties involved in the case who are present in the judicial session. First, the complainant or his/her representative and then the civil prosecutor, where there is a complaint involved, shall make statements.

If both parties present a complaint, priority in expressing the issues is given to the plaintiff.

\section{ARTICLE THREE HUNDRED NINETY-FIVE}

The prosecutor involved in the case shall give explanations regarding whether the decision of the court has been legal and whether it has been documented by evidence, after the statements made by interested persons.

\section{ARTICLE THREE HUNDRED NINETY-SIX}

After hearing the explanations given by the parties to the case and the opinion of the prosecutor, the judicial panel shall enter the consultation room in order to make a judicial decision.

\section{ARTICLE THREE HUNDRED NINETY-SEVEN}


The consultation of the judicial panel, the decision and the announcement shall take place according to the rules contained in Chapter twelve of Part Two of this Code.

\section{ARTICLE THREE HUNDRED NINETY-EIGHT}

The higher court after the preliminary proceedings of the case shall have the following jurisdiction at the final stage:

1- Sending the case to the authorized court for retrial in case of invalidating the decision of the lower court.

2- Deciding to issue a new decision in case of overruling the decision of the lower court or in case of a need for return of the case to the setting court for the purpose of gathering reasons and further research for a new proceeding.

3- Decisions of lower courts clear of situations of being invalidated and overruled, but involving mistakes and errors of numbers and figures shall not be invalidated or overruled by the higher court. They are returned to the lower court only for the purpose of correction and removal of the defect.

4- Approval of the decision of the lower court, in case its conformity with the law is established as a result of a review.

\section{ARTICLE THREE HUNDRED NINETY-NINE}

The grounds for invalidity of a decision are as follows:

1- Lack of the essential pillars of justice in the decision.

2- Absence of capacity on the part of one of the parties to the claim to litigate.

3- Issuance of judicial decision without the possibility of proof or against objective reality regarding the subject matter of the claim.

4- Issuance of a decision by a judicial panel without jurisdiction.

5- Issuance of a decision by a court without jurisdiction.

\section{ARTICLE FOUR HUNDRED}

The situations where a decision is overruled are as follows:

1- The decision not based on evidence.

2- Absence of explanation for situations which are necessary to clarify the case. 
3- Non-conformity of the reasons contained in the decision with the situations of the case.

4- Inappropriate use of the rules of the law.

5- Issuance of a decision of dismissal due to absence of the plaintiff.

6- Other decisions that can legally form the grounds for overruling the decision.

\section{ARTICLE FOUR HUNDRED ONE}

Affirmation of the decisions of lower courts by higher courts shall take place by a ruling.

\section{CHAPTER FIVE: \\ ISSUANCE OF A RULING BY THE HIGHER COURT OVERRULIGN AN INACCURATE DECISION}

\section{ARTICLE FOUR HUNDRED TWO}

The decision of the higher court concerning a situation of nullity shall be issued in the form of a ruling and the said ruling shall contain the following matters:

1- Date and place of issuance of the ruling.

2- Name of the court issuing the ruling.

3- Composition of the judicial panel.

4- Identity of the civil prosecutor and those involved in the proceedings of the case.

5- Identity of the complainant or the person presenting the objection.

6- A brief text of the lower court's decision.

7- A brief text of the presented complaint or objection.

8- Explanations of the persons involved in the proceedings of the case in the court.

9- Reasons giving rise to the civil case and the conclusion of the court.

10- The law on which the court has relied.

11- Decision of the judicial panel overruling the decision.

\section{ARTICLE FOUR HUNDRED THREE}


In case the decision is overruled and in case of the need for its submission for retrial, the higher court shall clarify the following matters in its ruling:

1- The situations of the case to be explained.

2- Grounds of proof to be demanded.

3- Other proceedings that take place in the lower court.

\section{ARTICLE FOUR HUNDRED FOUR}

The ruling of the higher court overruling the decision of the lower court is not subject to complaint and is final.

\section{ARTICLE FOUR HUNDRED FIVE}

1- Implementation of the contents of the ruling of the higher court invalidating or overruling the decision is mandatory in the new proceedings.

2- The lower court shall not in the issuance of its judgment be obligated to follow the ruling of the higher court without any preconditions.

\section{ARTICLE FOUR HUNDRED SIX}

In case of the rejection of a submitted complaint or objection, the higher court shall clarify in its ruling the reasons for the rejection.

\section{CHAPTER SIX: \\ SUBMISSION OF COMPLAINT AND \\ OBJECTION TO RULING OF LOWER COURT}

\section{ARTICLE FOUR HUNDRED SEVEN}

The parties to the case can complain against and object to the ruling of the court that has been issued in the preliminary stage.

\section{ARTICLE FOUR HUNDRED EIGHT}

The followings rulings can be subject to complaint and objection:

1- The rulings that have been issued by the provincial, city, municipal, district and sub-district courts, considering the authorization and non-authorization.

2- The rulings that are issued regarding the expiry or non-expiry of time. 
3- Other instances in which pursuant to this Code the ruling of the lower court is considered subject to complain and objection.

\section{ARTICLE FOUR HUNDRED NINE}

The higher court shall after proceeding with the complaint against and objection to the rulings of the lower court that are provided for in the law make decision in the following order:

1- Affirms the ruling and rejects the complaint or objection.

2- Overrules the ruling and returns the issue to the lower court for the purpose of a new trial.

3- Overrules the ruling that has been issued related to the essence of the claim and returns the case to the original court for the purpose of issuance of a decision.

\section{ARTICLE FOUR HUNDRED TEN}

The implementation of the issued ruling of the higher court overruling the ruling of the lower court is mandatory.

\section{CHAPTER SEVEN: \\ POWERS OF SUPERIOR COURTS IN PROCEEDINGS OF COMPLAINTS AGAINST ISSUED JUDGMENTS OF LOWER COURTS}

\section{ARTICLE FOUR HUNDRED ELEVEN}

If the authority of render a decision in a case according to the rules of this Code is transferred to another court, the complaint against the issued decision is submitted to the setting court or to the presidency of the court of the state/province within whose jurisdiction the court issuing the decision is located.

\section{ARTICLE FOUR HUNDRED TWELVE}

1- The right of complaint by the parties ends after the expiry of the specified time period.

2- If the substitute of one of the parties to the claim does not complain in the specified time period, the side that has suffered damages as a result can bring an action in the lower court against the substitute.

\section{ARTICLE FOUR HUNDRED THIRTEEN}

If one of the parties makes complaint within the specified time period, the other party shall, despite the expiry of the time period for complaint, have the right to complain until the end of the claim and until the issuance of the decision.

\section{ARTICLE FOUR HUNDRED FOURTEEN}


The persons whose complaint has been decided per se in the lower court or by representative, guardian, executor or curator, the right of complaint is also preserved for the same persons.

\section{ARTICLE FOUR HUNDRED FIFTEEN}

The superior court cannot without the prior decision of the lower court directly resort to resolving the claim, unless otherwise provided for in the law.

\section{ARTICLE FOUR HUNDRED SIXTEEN}

The clear or implicit consent of a minor, insane, interdicted or guardian, executor, representative and curator with the decision of the court is not valid. An proxy who has been given the authority of satisfaction by his/her principal is exempt from this rule.

\section{ARTICLE FOUR HUNDRED SEVENTEEN}

The following situations are considered as implicit satisfaction with the decision of the lower court:

1- Compromise between the person convicted and the person in whose favor the judgment of conviction has been issued regarding the court expenses or duties.

2- Request for time for payment of debt by the convicted person from the person in whose favor the conviction has been issued.

3- Absence of complaint by the complainant against the actual issue, but rather reliance on a complaint regarding the expenses of the court.

\section{ARTICLE FOUR HUNDRED EIGHTEEN}

If the complainant or the objecting party presents its complaint and objection within the specified time period, but does not appear in the higher court without notice and justifiable excuse, the court shall issue its decision ending the right of complaint or objection, and the decision of the court shall, after being recorded in the (relevant) office, be announced to the concerned authorities.

\section{ARTICLE FOUR HUNDRED NINETEEN}

In non-appearance in the court at the specified time period of the party opposing the objecting party, the right of the objecting party shall remain as before.

\section{ARTICLE FOUR HUNDRED TWENTY}

The end of the right of objection by the objecting party for reason of the expiry of the time period and the relation of the judgment of the lower court to a third person cannot obstruct the right of that third person to complain against the decision of the lower court. 


\section{ARTICLE FOUR HUNDRED TWENTY-ONE}

The objection by the third person after the implementation and performance of the final judgment is not valid without the presentation of a justifiable excuse.

\section{ARTICLE FOUR HUNDRED TWENTY-TWO}

Overruling and invalidating the judgment of a city, municipal, district and sub-district courts cannot take place by a court of the same level as these courts.

\section{ARTICLE FOUR HUNDRED TWENTY-THREE}

The authority of a superior court to hear a complaint has been legally limited by taking into account the price of the subject matter of the claim. The claims whose issues are mentioned as follows are exempted from this limitation:

1- Claim related to the right of honor or claim for its establishment.

2- Claim related to the closing of door and window.

3- Claim related to the division of bequeathed property.

4- Right of pre-emption in the way of proving abandonment and avoidance of the claim.

5- Claim related to the height of the neighbor's building and request for protection against its harm.

6- Claim related to defense against the harm resulting from a drainage in the direction of another person's courtyard.

7- Claim related to the digging of a new sub-stream from the common stream.

8- Claim related to digging of a canal as a result of the digging of which a harm is done to the satisfaction of another.

9- Claim of invalid individuals, persons lacking legal capacity and the absentee who have been plaintiff or defendant and a judgment has been issued at their detriment.

10- Claim related to the right of water.

11- Claim related to the right of passage.

12- Claim related to the passage of time.

13- Claim in which the government is a party and the representative of the government cases is the person convicted. 


\section{ARTICLE FOUR HUNDRED TWENTY-FOUR}

If there are multiple convicted persons and one of them presents the complaint and if the judgment is considered divisible, the persons who have not complained cannot benefit from the complaint of the party making it.

\section{ARTICLE FOUR HUNDRED TWENTY-FIVE}

Rules related to the complaint and objection against the non-final decisions of the lower courts and the issued judicial rulings can also be applied to the final judgments and rulings of the lower courts.

\section{ARTICLE FOUR HUNDRED TWENTY-SIX}

Tribunals of the provincial court shall proceed with the civil cases pursuant to the complaint of a party to the claim or objection of the prosecutor to the final judgments in case of violation of the rules of the law, mistake in the implementation of the law, mistake in the interpretation or invalidity in the proceedings in a manner that has led to the issuance of an illegal judgment.

\section{ARTICLE FOUR HUNDRED TWENTY-SEVEN}

In case the decision and ruling of the lower court is issued according to the provisions of the law and are clear of mistakes, if the complaint and objection against the decision is considered baseless, the higher court shall issue its judicial ruling upholding the legality of the final judgment and ordering its implementation.

\section{ARTICLE FOUR HUNDRED TWENTY-EIGHT}

If (the principal of) legality has not been complied with in the decision of the lower court, the provisions of clause 2 of Article 298 of this Code are applicable.

\section{ARTICLE FOUR HUNDRED TWENTY-NINE}

If the final decision of the lower court is subjected to a revocation, the case is transferred to the authorized court for a retrial.

\section{PART FOUR: \\ PROCEEDINGS IN OFFICE OF CIVIL CASES AND PUBLIC RIGHTS OF SUPREME COURT}

\section{ARTICLE FOUR HUNDRED THIRTY}

The powers of the civil cases and public rights tribunals of the Supreme Court in the transferred cases are as follows:

1- The preliminary proceedings of the cases according to the specification of the law. 
2- Proceedings in the final stage.

3- Proceedings from the point of view of legality.

\section{CHAPTER TWO: PRELIMINARY HEARING OF CASES}

\section{ARTICLE FOUR HUNDRED THIRTY-ONE}

The tribunal of the Supreme Court dealing with civil cases and public rights shall hear the cases that have been referred to it for the purpose of preliminary proceedings according to the provisions of the law.

\section{ARTICLE FOUR HUNDRED THIRTY-TWO}

The judgments of the provincial court and the main district are dealt with in a preliminary proceeding in the tribunal of the Supreme Court dealing with civil cases and public rights, in case they are overruled for a second time.

\section{ARTICLE FOUR HUNDRED THIRTY-THREE}

The judgment of the tribunal of the civil cases of the Supreme Court that is issued according to the provisions of Articles 431 and 432 of this Code is final.

\section{ARTICLE FOUR HUNDRED THIRTY-FOUR}

The principles of trial and the rules that are applicable in the resolution of cases in the preliminary stage are also applicable in the preliminary proceeding of the civil cases tribunal of the Supreme Court.

\section{ARTICLE FOUR HUNDRED THIRTY-FIVE}

In case of the difference of opinion in the decision that first is subject to the proceedings of the tribunal the final decision is issued with the majority of opinion.

\section{CHAPTER THREE: CONDITIONS FOR BRINGING FINAL APPEAL AND PROCEEDINGS RELATED TO IT}

\section{ARTICLE FOUR HUNDRED THIRTY-SIX}

The non-satisfied party, the civil prosecutor and the representative of the office of the government cases can present their complaint and objection to the setting court or the tribunal of civil cases and public rights of the Supreme Court regarding the cases that have been decided in a preliminary manner by the tribunals of provincial courts, the main district and the city court. 
The court is obligated to record the appeal and to give the person making the appeal a written receipt.

\section{ARTICLE FOUR HUNDRED THIRTY-SEVEN}

1- The time period for final appeal is two months.

2- The calculation of this period commences from the date of announcement of the judgment.

\section{ARTICLE FOUR HUNDRED THIRTY-EIGHT}

The place in which the final appeal is made in the center of Kabul is the tribunal of civil cases and public rights of the Supreme Court, and in the provinces the person making final appeal can deliver its appeal to the presidency of the provincial court.

\section{ARTICLE FOUR HUNDRED THIRTY-NINE}

In the public interest cases, the non-satisfied party, representative of the office of the government cases or the civil prosecutor each can petition for a final appeal.

\section{ARTICLE FOUR HUNDRED FORTY}

A final appeal consists of the following:

1- The introduction of the parties to the claim.

2- The name of the court issuing the judgment.

3- The ratio decidendi of the decision from which a complaint is made.

4- The date of the announcement of the judgment of the court.

5- Grounds for bringing final appeal.

\section{ARTICLE FOUR HUNDRED FORTY-ONE}

The final appeal which does not comply with the rule of Article 440 of this Code is rejected by the authority dealing with the final appeal, and the interruption time resulting from this is not counted as part of the legal time period for petitioning for the final appeal.

\section{ARTICLE FOUR HUNDRED FORTY-TWO}

Expression of non-satisfaction at the bottom of the notice of the judgment is also considered as a final appeal.

\section{ARTICLE FOUR HUNDRED FORTY-THREE}


The court issuing the judgment shall prepare the form of the petition for final appeal according to the rule of Article 440 of this Code.

\section{ARTICLE FOUR HUNDRED FORTY-FOUR}

If the petition for final appeal is submitted to the office of civil cases and public rights of the Supreme Court, the office of documents of this office shall demand the papers related to issue and decision of the lower court from the relevant authority.

\section{ARTICLE FOUR HUNDRED FORTY-FIVE}

The authority dealing with a petition for final appeal in the provinces is obligated to officially send the papers of the issue to the Supreme Court within one week.

\section{ARTICLE FOUR HUNDRED FORTY-SIX}

Non-compliance by the relevant authorities with the legal steps for dealing with the final appeal that leads to a delay in sending of papers and as a result causes harm shall render those authorities liable.

\section{ARTICLE FOUR HUNDRED FORTY-SEVEN}

In cases in which the government is involved, the papers are transferred to the office of the Supreme Court by the office of government office as a result of the complaint by the person convicted or the objection of the representative of the office of government cases.

\section{CHAPTER FOUR:}

\section{PROCEEDINGS IN THE FINAL STAGE}

\section{ARTICLE FOUR HUNDRED FORTY-EIGHT}

The provisions contained in Part Three of this Code are applicable in the proceedings in the final stage in the office of the civil cases and public rights of the Supreme Court. The situation of overruling and referral of the case to the lower court is exempted from this rule.

\section{ARTICLE FOUR HUNDRED FORTY-NINE}

The Supreme Court shall have the following powers in the final stage of proceedings of the cases:

1- Overruling or invalidating the decision or ruling of the lower court in whole or in part and sending the case for retrial by the same judges or another composition to the relevant court.

2- Issuance of a decision for the purpose of correcting a violation in the legal reasoning, if after overruling the decision no need has been felt for collection of new or complementary reasons in 
the case, and the situations of the case have been dealt with in a complete and correct manner by the lower court, and where only in the legal reasoning a violation has taken place.

3- Return of the papers for new trial in case of the dismissal of the court's ruling due to the fact that the proceeding of the issue requires the issuance of a decision. In this case, the presence of the parties is not necessary in the tribunal of the Supreme Court.

4- Affirming a judgment of the lower court in case of its issuance according to the law.

\section{CHAPTER FIVE: \\ PROCEEDINGS OF THE FINAL RULES OF THE LOWER COURTS FROM THE POINT OF VIEW OF LEGALITY}

\section{ARTICLE FOUR HUNDRED FIFTY}

The final appeal proceedings regarding the final judgments of the provincial, main district and Kabul city courts is within the jurisdiction of the Supreme Court which is implemented by the tribunal of civil cases and public rights of the Supreme Court based on the petition for final appeal by the petitioner.

\section{ARTICLE FOUR HUNDRED FIFTY-ONE}

1- The tribunal of the civil cases and public rights of the Supreme Court shall take up the final judgments of the lower courts only from the perspective of legality and of their conformity with the rules of the Islamic law.

2- If the said office becomes confident as a result of close attention that the judgment of the lower court has been issued in conformity with the rules of Islamic law, it shall reject the complaint and objection and issue a ruling for the application of the final judgment.

3- If as a result of the close attention by the office related to the Supreme Court, it is proven that there have been legal violations in the final judgments of the lower courts, the court shall overrule the decision and clarify its conditions with reasons, and shall return it to the lower court for issuance of a new decision.

\section{ARTICLE FOUR HUNDRED FIFTY-TWO}

The grounds for invalidity of the final judgments of the lower courts as provided in Article 399, and the grounds for overruling as provided for in Article 400 of this Code in the stage of proceeding with the final judgments of the lower courts are also applicable from the point of view of legality.

\section{ARTICLE FOUR HUNDRED FIFTY-THREE}


Proceedings regarding the final judgments of the lower courts for reasons of non-satisfaction in the civil tribunal of public rights of the Supreme Court are not confined to the presentation of the objection. In case of the existence of legal flaws the said judgments are overruled.

\section{ARTICLE FOUR HUNDRED FIFTY-FOUR}

In overruling a decision for reason of its conflict with the rules of law, consideration is given to the legislative documents that were in force during the issuance of the judgment of the lower court.

\section{ARTICLE FOUR HUNDRED FIFTY-FIVE}

Renewal of proceeding of an overruled decision by the order of the tribunal of the Supreme Court in the lower courts is not restricted to the presentation of a new demand and request.

\section{ARTICLE FOUR HUNDRED FIFTY-SIX}

Objections outside the issue under consideration by the court in the stage of final appeal cannot be justiciable and are considered a new claim.

\section{ARTICLE FOUR HUNDRED FIFTY-SEVEN}

The judgments that are issued in the incidental claim while the original claim is under adjudication cannot be subject to final appeal prior to the resolution of the original claim.

\section{ARTICLE FOUR HUNDRED FIFTY-EIGHT}

Lodging final appeal stops the implementation of judgments related to the decision of the lower court.

\section{ARTICLE FOUR HUNDRED FIFTY-NINE}

The tribunal of civil cases and public rights of the Supreme Court can require the appearance of the parties to the claim while adjudicating the final judgments of the lower courts from the point of view of legality.

\section{ARTICLE FOUR HUNDRED SIXTY}

If as a result of demand and complaint by the party to the claim the tribunal related to the Supreme Court can overrule the judgment of the tribunal of provincial court that has been issued pursuant to the expiry of the time period or rejection of the right of appeal by the party to the claim. The court returns the issue to the tribunal of the lower court for new proceedings.

\section{ARTICLE FOUR HUNDRED SIXTY-ONE}


If the ruling or the judgment related to the expiry of the time period that has been issued from the tribunal related to provincial court cannot be overruled and if the complainant or the objecting party only complains against or objects to the legality of the decision of the first court, the provincial court shall adjudicate the case from the point of view of legality.

\section{ARTICLE FOUR HUNDRED SIXTY-TWO}

If the office related to the court of the provincial court against the decision of the tribunal of civil cases and public rights of the Supreme Court issues judgment and the said tribunal considers the second decision of the provincial court liable to be overruled, the full board of the Supreme Court's civil cases shall adjudicate the matter.

\section{ARTICLE FOUR HUNDRED SIXTY-THREE}

If the tribunal of the civil cases and public rights of the Supreme Court is not satisfied with the reasons submitted after the issuance of the second decision of the tribunal related to the lower court, it shall issue a ruling for the implementation of the judgment.

\section{ARTICLE FOUR HUNDRED SIXTY-FOUR}

The ruling of the provincial court overruling the judgment of the lower court and the return of the claim to the said court cannot be the subject to final appeal in the tribunal of the civil cases and public rights of the Supreme Court.

\section{ARTICLE FOUR HUNDRED SIXTY-FIVE}

If the decision of the lower court is clear of the defect of invalidity and if it only contains small defects and defects of the form, the decision shall be returned to the court issuing the judgment for correction of the defect. In this case, there is no need for renewal of the claim and appearance of the witnesses.

\section{ARTICLE FOUR HUNDRED SIXTY-SIX}

The tribunal hearing the final appeal can demand the original papers that the parties to the claim have presented to the lower court for the purpose of consideration.

\section{ARTICLE FOUR HUNDRED SIXTY-SEVEN}

If the party lodging the final appeal fails to present its objection to the tribunal adjudicating the final appeal within one month from the arrival of the case and has not justifiable excuse for such failure, or it does not appear by itself, a judicial ruling is issued for the implementation or dismissal of the lower court's decision.

\section{ARTICLE FOUR HUNDRED SIXTY-EIGHT}

The ruling issued by the final appeals court contains the following matters: 
1- Identity, occupation and place of residence of the parties to the claim.

2- The reason that gave rise to the claim.

3- The judgment of the lower court.

5- Summary of the objection and the reasons presented by the parties.

6- Grounds for rejection and invalidation from the point of view of legality.

\section{ARTICLE FOUR HUNDRED SIXTY-NINE}

The decision or the ruling that has been overruled or invalidated by the tribunal of final appeal is remanded to the setting court. The court to which the decision is transferred is obligated to enter the judgment or the decision of final appeal with the same words into its second decision. In the absence of compliance with this issue the decision shall be overruled for the second time.

\section{ARTICLE FOUR HUNDRED SEVENTY}

If in a claim the convicted party is more than one person and as a result of final appeal by one of them the decision (of the lower court) is revoked, others cannot make use of this revocation. The following situations are exempted from this rule"

1- Conviction of the principal and proxy for payment of debt.

2- Assignment and division of lands and common properties between the heirs and partners.

\section{ARTICLE FOUR HUNDRED SEVENTY-ONE}

If the party appealing from the decision of the appellate court dies prior to the consideration by the court of final appeal, the rights of final appeal devolves to its successors.

\section{ARTICLE FOUR HUNDRED SEVENTY-TWO}

The appellant cannot lodge final appeal against a third person outside of the decision.

\section{ARTICLE FOUR HUNDRED SEVENTY-THREE}

If the appellant dies after the expiry of the limitation period for bringing the final appeal, his/her successors do not have the right to bring the final appeal. Justifiable excuse is exempt from this rule.

\section{ARTICLE FOUR HUNDRED SEVENTY-FOUR}


Not having tested the character of the required witnesses shall render the decision subject to examination by the tribunal of last resort and shall lead to the return of the case back to the setting court.

\section{ARTICLE FOUR HUNDRED SEVENTY-FIVE}

Emergence of difference about the right to bring final appeal or the expiry of the time period shall lead to the adjudication of the issue by the tribunal of final resort.

\section{ARTICLE FOUR HUNDRED SEVENTY-SIX}

The tribunal of final resort shall perform its adjudication of the case according to the following:

1- Examination of the strength and weakness of the reasons submitted by the parties to the claim.

2- Examination of the strength and weakness of the grounds contained in the judgment of the lower court.

\section{ARTICLE FOUR HUNDRED SEVENTY-SEVEN}

The lower courts are obligated to record in a clear manner in the decision their available reasons, the (name of the) parties to the claim and their reasons, supported by evidence with the mention of the legal articles and details of the Islamic law.

\section{ARTICLE FOUR HUNDRED SEVENTY-EIGHT}

Rejection or acceptance of the objections of the party making the final appeal shall having regard to the submitted reasons and documents be recorded in the ruling article by article.

\section{ARTICLE FOUR HUNDRED SEVENTY-NINE}

The rulings issued by the lower court cannot be subject to final appeal in the following situations:

1- The judgments that are based on a clear confession or exoneration and the party making the final appeal only denies its apparent confession or exoneration and there do not exist strong reasons to render the instrument suspect.

Existence of witnesses that repeatedly negate the lack of presence and absence of confession are exempt from this rule.

2- Extinction of the right of final appeal as a result of the consent of the parties that has assumed the official form.

3- The judgment of the arbitrator that the parties have willingly admitted the absoluteness of that judgment and that judgment has been recorded in the legal security document. 


\section{PART FIVE: \\ REVIEW OF THE FINAL DECISIONS AND \\ RULINGS IN THE CIVIL AND PUBLIC INTEREST CASES \\ CHAPTER ONE: \\ REVIEW (APPEAL)}

\section{ARTICLE FOUR HUNDRED EIGHTY}

The chief justice and the chief prosecutor who have been harmed can each for reasons of the emergence of new evidence object to the final rulings or decisions of the courts.

\section{ARTICLE FOUR HUNDRED EIGHTY-ONE}

Review of the final decisions or rulings of the courts shall be within the jurisdiction of high council of the Supreme Court.

\section{ARTICLE FOUR HUNDRED EIGHTY-TWO}

The situations for appeal/review are as follows:

1- Proof of the falsehood of the testimony of the witnesses.

2- Proof of the falsehood of conclusions of the experts.

3- Proof of forgery and falsification in the documents and sources of proof.

4- Proof of inaccurate translation that would affect the judgment.

5- Presentation of a proving document by the convicted person which does not exist during the issuance of the judgment.

6- Other new evidences that have not been known to the court during the examination of the issue and has not become known after the issuance of the judgment or has not been noticed during the proceedings of the settlement, and if the above-mentioned evidence can be grounds for the cancellation of judgment.

\section{CHAPTER TWO: \\ PROCEEDINGS RELATED TO APPEAL (REVIEW)}

\section{ARTICLE FOUR HUNDRED EIGHTY-THREE}

If justifiable reasons exist to render the final judgment abrogated, the high council of the Supreme Court shall issue a ruling canceling the judgment and shall return the case to the setting court or another court for retrial. 


\section{ARTICLE FOUR HUNDRED EIGHTY-FOUR}

If the high council of the Supreme Court determines that the case subject to review/appeal is worthy of further examination, it shall assign the background materials of the case for preliminary assessment to a commission composed of two members of the civil tribunal under the presidency of one of the members of the high council of the Supreme Court.

\section{ARTICLE FOUR HUNDRED EIGHTY-FIVE}

The preliminary commission shall consider the objection to the final decision of the objecting party and in the light of the provisions of Article 482 of this Code examine it.

If it is necessary, the commission can summon the parties to the case and question them on the nature of the issue.

\section{ARTICLE FOUR HUNDRED EIGHTY-SIX}

The assigned commission shall arrange its opinions in two copies and shall submit them along with the background (materials) to the head of the secretariat of the high council of the Supreme Court.

\section{ARTICLE FOUR HUNDRED EIGHTY-SEVEN}

If the person making the appeal has suffered damages, the authorized place for submission of the appeal is the Supreme Court.

\section{ARTICLE FOUR HUNDRED EIGHTY-EIGHT}

1- The time period for submission of an appeal from the final judgments in personal cases (family cases) is a period of three months.

2- The start of the period provided for in clause 1 of this article is calculated from the date of issuance of the final decision.

\section{ARTICLE FOUR HUNDRED EIGHTY-NINE}

The time period for hearing an appeal after the submission of the objection is a period of three months.

\section{PART SIX: \\ MISCILANEOUS RULES}

\section{ARTICLE FOUR HUNDRED NINETY}

The decisions and rulings of the non-judicial gatherings in civil matters and public rights are not valid. 


\section{ARTICLE FOUR HUNDRED NINETY-ONE}

Judgment in matters of the Civil Code takes place after the submission of request of the claim.

\section{ARTICLE FOUR HUNDRED NINETY-TWO}

The judge cannot transfer to another judge the authority of judgment, unless otherwise provided in the law.

\section{ARTICLE FOUR HUNDRED NINETY-THREE}

The judge cannot postpone and delay without legal reason the resolution of cases within his/her authority.

\section{ARTICLE FOUR HUNDRED NINETY-FOUR}

The judge is obligated to seriously object to the speech and actions that are judicial probity.

\section{ARTICLE FOUR HUNDRED NINETY-FIVE}

The judgment of the judge can be limited, specified and analyzed by taking into account the time, place, issue and event.

\section{ARTICLE FOUR HUNDRED NINETY-SIX}

If the subject matter of the claim is a debt or purchase of moveable and immoveable properties, and the defendant has died without leaving any legal heir, the tribunal of the government cases is recognized as the legal successor of the deceased and the court shall adjudicate the issue.

\section{ARTICLE FOUR HUNDRED NINETY-SEVEN}

The judge cannot dictate to the plaintiff, defendant and witnesses in any manner.

\section{ARTICLE FOUR HUNDRED NINETY-EIGHT}

The judge must, in addition to having complete grasp and understanding of the effective laws of the country and of the rules of the Islamic law, have complete awareness of the general culture, manners and customs of the society.

\section{ARTICLE FOUR HUNDRED NINETY-NINE}

The judgment of the court based on the sources of evidence for and against one or some of the heirs is tantamount to a judgment for and against all of the heirs.

\section{ARTICLE FIVE HUNDRED}


The court is a venue and not a proving party. The subject matter of a judgment is in fact a fixed matter and the judge expresses it based on the legal and legitimate reasons.

\section{ARTICLE FIVE HUNDRED ONE}

In the absence of the clear rules of law, the judgment of the judge are issued according to the fundamental principles of the Islamic law and shall possess the force and strength with regard to the subject matter of the ruling.

\section{ARTICLE FIVE HUNDRED TWO}

A minor, insane, idiot, interdicted and absentee cannot directly be a legal adversary.

\section{ARTICLE FIVE HUNDRED THREE}

The decisions of the city, municipal, district and sub-district courts that are based on the confession of the plaintiff or defendant or are based on a credible instrument of a ruling issued pursuant to the confession of the plaintiff, defendant and their heirs or a legal waiver cannot be appealed against. The higher court shall decide against the grant of leave for appeal in such cases. Doubtful instruments are exempt from this rule.

\section{ARTICLE FIVE HUNDRED FOUR}

The Supreme Court is obligated to enact for the purpose of effective implementation of the rules of this Code special rules and regulations that have been approved by the high council of the Supreme Court regarding conditions for accuracy of the claim.

\section{ARTICLE FIVE HUNDRED FIVE}

Decisions of the district and sub-district courts in which the taking of oath or waiver of dropping of oath are the grounds for judgment are subject to the following actions:

1- In case the said decision is overruled in the superior court, the procedures and rules contained in Chapter Four of Part Three of this Code shall be observed.

2- In case the said decision is not overruled in the higher court and the plaintiff demands (the right) to bring witnesses, the tribunal of the provincial court and a court equivalent to it shall refer the case in pursuant to a judicial ruling to the relevant court for proceedings related to the testimony of witnesses.

3- In a court to which a case has been assigned, only the question of presentation of witnesses is recorded in the new claim form (pleading) and the defendant is asked to bring witnesses. The new proceedings of the case for this purpose do not require a new action.

4- The time period allowed for bringing witnesses after the commencement of the new proceedings in the court shall be one month. 
5- If the plaintiff brings witnesses and the said witnesses are accepted or rejected, the case must pass through the higher courts in either case.

6- If the plaintiff fails to bring witnesses within one month, the original decision becomes absolute.

7- The legal action in the original court for the purpose of presenting witnesses is considered to be completely the same as the initial decision which cannot be appealed against in the appellate or supreme courts.

\section{ARTICLE FIVE HUNDRED SIX}

This law shall come into force one month after it is published in the official gazette and upon entry into effect of this law, the Code of Administrative Rules of Judicial Courts, dated October 10, 1959, with its attachments, the Rules of Procedure for Legal and Judicial Courts, dated December 2, 1960, Code of Rules for Determination of Time Period for Preliminary Claims and the Hearing of Appeal in the Appellate and Supreme Courts, dated September 17, 1955 with all its appropriate attachments and amendments and the single article of the Procedure for Administrative Trials, effective as of January 14, 1952 and the rules of other laws of legislative documents that are contrary to the rules contained in this Code are considered overruled.

URL: http://www.asianlii.org/af/legis/laws/cpc1990169

Editor: Shahjahan Bigzad

Assistant Editor: Nuralam

Issue: No. 10, August 22, 1990

Serial No.: 722 


\section{EXCERPTS FROM THE LAW OF COMMERCE OF AFGHANISTAN OF 1334}

(Caution: Many sections of the Law of Commerce have been superseded by legislation enacted subsequent to the adoption of the 2004 constitution)

Chapter One - Introduction

Article 1: The provisions of the Commerce Laws are applicable to all commercial transactions.

Article 2: Commercial disputes are to be settled in accordance with legally binding agreements and in their absence disputes are to be determined and settled by reference to the meaning and implication of existing commercial laws. In the absence of a law, local and special customs (those that are commonly recognized, consented to, and used) are applied. Local customs and practice are preferred to general custom. In the absence of any other of the above - mentioned methods any other laws which might apply to the dispute are used.

Remark: The preference of local and special custom and practice to general custom and practice is given because the custom of and practice of locality are the out come of business transactions of the area. If a clear-cut custom relating to a dispute in one particular locality does not exist, the custom of the nearest locality to this dispute is applied.

Article 3: In the absence of any other explicit laws, the contents of Article 2 are applied.

Chapter 2 - Commerce and Commercial Capacity

Article 4: Every individual having reached the age of eighteen is permitted to engage in commercial activities provided he is not legally debarred of his legal rights.

Article 5: When a business has passed to a minor, the legal authorities shall consider if the continuation of such a trade by his legal agent is beneficial to the interest of the minor. In case the executer or the legal agent should not have the legal commercial capacity, he is not permitted to carry on until a new agent or guardian has appointed.

Article 6: The rulings of Article 5 are applicable to other individuals lacking commercial capacity.

Article 7: All persons who under law of promotion and retirement of civil servants are counted as employees of services of the state are barred from engaging in direct commercial activities.

Article 8: Everyone, whether as an individual or a member of a corporation, who possesses legal commercial capacity and who in his own name has engaged in one or more commercial activities and who has made commercial activities his habitual business is considered a merchant.

Article 9: A person who has opened a center for his commercial activities and who advertises to the public through circular letters and the press is considered a merchant even if his habitual business is not commercial activity. 
Article10: An individual performing a commercial transaction by chance or by coincidence shall not be considered a merchant. The transaction and activities performed must be governed by the regulations of commercial laws.

Article 11: Provinces and municipalities may engage in commercial activities. They are not considered merchants but their commercial transactions are governed by commercial law.

Article 12: People whose commercial activities are based more on physical strength than on cash capital, or whose income is so little it barely suffices for their living, regardless of whether they are stationed in a shop or move around, are considered small merchants (small businessmen).

Article 13: Small merchants do not have to have a business title or keep the commercial registry books and neither are they affected by the bankruptcy regulations.

Remarks: Those who are in one of the trade classes and who are required to get a business class permit are classified as small businessmen.

Subchapter C - Commercial Transactions

Article 14: For merchants / non-merchants who purchase movable and personal property for sale or lease to other persons in original or altered form, the sale or leasing of such properties is considered a commercial transaction.

Article 15: Leasing of movable and personal property by merchants and non-merchants for the purpose of leasing it to others is considered a commercial transaction.

Article 16: Employment of persons for the purpose of contracting them to others by individuals, whether merchants by vocation or otherwise, is considered a commercial transaction.

Article 17: If a landowner, farmer, or a cattle-raiser sells his products or changes them to other forms before selling them, such action should be considered as normal or ordinary activities. Similarly, if a farmer with agricultural and industrial machines or plants exchange his product or if a professional person or his employee (or his machines) produces his professional product and sells them; or if an author publishes his books and sells them, these activities constitute ordinary activities. But if a person for the purpose of changing his agricultural product opens a permanent establishment possessing the qualities of an industrial business, this is considered a commercial transaction.

Article 18: The following transactions are commercial and business transactions:

Agreement to provide any kind of movable property and accept any kind of activities and products.

Establishment of a power plant or press; photography; printing; and selling of books.

Establishment of theaters, movies, parks and public places, e.g., hotels, business compounds, restaurants and the like, employment offices, and auction places. 
Transportation of passengers, animals, and goods via land, air, and water Distribution of water, gas, electricity and the establishment of telephone communication.

Article 19: The following transactions are commercial transactions regardless of the parties concerned:

Working for commission.

Brokerage.

Bill and draft transactions (whether recorded in the name of a person or a bearer).

Money exchange transactions.

Transactions made by private and public (special and general) banks.

Transaction relating to current accounts and agreements thereof.

Transactions relating to mortgage documents and receipts existing against goods placed in commercial general storehouses.

Establishment of commercial companies and buying and selling of shares.

Contraction of any kind of insurance for all risks whether for fees or for reciprocal terms.

Article 20: All transactions of a merchant are assumed to be commercial unless proved ordinary.

Article 21: If an agreement between parties is commercial to only one of the parties, provided there are no statements to the contrary in the law, the obligation arising form this agreement on the part of the contractors are subject to the Commercial Law.

Article 22: Obligations arising for a merchant or non-merchant from other transactions or from transactions or from transactions similar to those mentioned in this chapter, are inherently subject to the regulations of the Commercial Law.

Article 23: All transactions relating to the transactions of this chapter are taken as commercial transactions.

Subchapter H - Business Agents

Article 85: A person delegated by a merchant to engage in the business activities of the merchant in any locality, whether it be that of the business center or not, is called a business agent for the merchant.

Article 86. A merchant is responsible for those activities and transactions of his agent which he has delegated to him. If a person is agent for more than one merchant, each merchant is responsible in turn for the transactions of the agent. If a person should happen to be delegated as an agent by a business firm, the responsibility of each of the partners, or stockholders, of the firm will determined by the kind of business.

Article 87: The agency right to person is delegated explicitly or incidentally. The document showing the explicit agency must be registered in the registration office of the locality in which the agent is working and it should also be advertised in that locality. Otherwise, the contents of Article 88 are applied. 
Article 88: If a person is an undisclosed agent of a merchant, the agent's right as far as third parties is concerned is unlimited and his Agency includes all transactions that can be made during that specific business. If the agent should enter into business transaction with a third party, and if the principal should be precluded from proving that the third party knew of the limitation of the agent's rights during the course of the transaction, the claim of the principal regarding the limitation of his agent's rights against the party is not valid.

Article 89: If an agent executes his transactions always in the name of the principal, namely, the owner of the establishment, he must, at the time of signing, put beside his name the name of the merchant and his identify or his business title and add the word "for" or an equivalent word; otherwise, he will be personally responsible for transactions that he has executed. If other people face problem with the agent in transactions that are delegated to him, they can also bring suit against the principal.

Article 90: In case a person goes into an agency without being authorized by a merchant, and his transactions do not receive the approval and certification of the merchant, the self-appointed agent is subject to pay the losses suffered by an innocent third person.

Article 91: An agent cannot, without the explicit approval of his principal, execute any transactions in his own name or in the name of or in partnership with other persons. An agent deviating from this is subject to pay any loss suffered through his transactions. But if the agent in doing so makes a profit, the merchant is entitled to it.

Article 92: Invalidating or limiting an agent's right is subject to registration and advertisement.

Article 93: An agent can bring suit against others in the Court in the name of his Principal regarding the transactions such Debts and etc, delegated to him and others can also bring suit against the agent.

Article 94: The contents of this chapter are applicable for the agents of foreign firms, in whose names they are executing transactions in Afghanistan.

\section{Chapter III - Commercial Documents}

Subchapter A - Drafts or Bills of Exchange

Part I - Form and Preparation of Bills of Exchange

Article 471: Bills of exchange must contain the following:

The words "Bill of exchange" should be written in the text of the document in whatever language the bill of exchange has been written.

The order of the payment of a specific amount, unconditionally.

The name of the payee.

The item of payment. 
The place of payment.

The name of the person authorized to receive the money.

The place and date the bill of exchange is written.

The signature of the person issuing the bill of exchange.

Article 472: Documents lacking any of the items of Article 471 will not be considered a bill of exchange except in the following situations:

The bill of exchange whose payment time is not specified is payable upon presentation.

For bills of exchange not showing the place of payment, the place mentioned after the name of the addressee is the place of issuance is not mentioned, the place following the name of the person issuing the bill of exchange is considered the place where the bill of exchange has been issued.

Article 473: Bills can be written to be payable by order of writer, or to the writer, or to the account of a third person.

Article 474: Payment of a bill of exchange can be restricted to the residence of the third person, whether at the home of the addressee or elsewhere.

Article 475: For bill of exchange which are payable either "on sight" or after a specified time, the one issuing the bill of exchange can make it conditional that a portion of the payment shall constitute interest. This provision is not allowed with respect to other bills.

Article 476: In cases where the amount of a bill of exchange is written both in letters and figures, and there is difference between these two, the amount written in letters is honored. In case the amount of a bill of exchange is written more than once all in letters or all in figures, the there is a difference between these amounts, the lesser amount honored.

Article 477: The signatures of those not qualified or authorized to sign a bill of exchange can not affect the signatures of those who are qualified and authorized.

Article 478: A person, not counsel for another person, who signs a bill of exchange in the letter's name and account is liable for that bill of exchange. This order is also valid where counsel violates his authorized limitations.

Article 479: Acceptance and repayment of bills must be assured by the issuers. Any denial of ability to assume and repay the bills when due is not valid or allowable.

Part III - Acceptance

Article 490: A negotiable note can be presented for acceptance before the specified time at the residence of the addressee by the bearer or any person having it.

Article 491: the writer can specify in the note, for the acceptance of the addressee, the due date, or the writer can write the obligation of the bearer for acceptance without specifying the date. 
The writer can also make the condition that a note can not be accepted for payment before a specific date. Unless the writer writes the statement "unacceptable", every endorser can, with or without specification of the passage of a period of time, make the note due.

Article 492: Notes whose presentations are subject to a specific period of time should be presented within six months after the time the note has been written. The writer can either increase or decrease this period, but the endorser can only decrease it.

Article 493: The bearer who presents a note for acceptance does not have to turn it over to the acceptor prior to payment. The bearer, in due course, can present the note the day after it has been first presented. If the bearer protests against additional delay, interested parties are not permitted to withstand the second claim.

\section{Part IV - Guaranty}

Article 499: The payment of a negotiable note, in part or in full, could be executed through guaranty. The guaranty will probably be made by a third person or by one of the signatories.

Article 500: The endorsement should be registered on the note or on paper attached to the note. "Guaranty" or words saying it is guaranteed, or some similar expressions are added and singed by the guarantor. The signature of persons other than the issuer and addressee on the draft will convey guarantee. It must be specified on the guaranty whose account is guaranteed. If it is not specified, it will be accounted in the account of the issuer.

Article 501: The guarantor is as much responsible as the person who has been guaranteed. If the note is not prepared in accordance with the law, the guarantor is not responsible for his promise. If the guarantor does pay the amount of the note, he is entitled to refer to the person guaranteed for or to those who are responsible for the person guaranteed for.

Part VI - Payment

Article 507: The bearer must refer to the addressee on the date the note is payable or, at the most, after two working days.

Article 508: When the addressee pays the amount of the note, he requests the bearer to sign it as evidence of payment, and then he should keep the note. Partial payment of a note is not rejected, but the addressee can request to have the signature for the part paid as evidence of payment.

Article 509: The bearer of a negotiable note does not have to receive the amount before the due date. The addressee paying the note before the date due is himself responsible for any loss caused by this act. The person paying the note close to the date due has no responsibility provided this should have taken place through no fault or bad intention of his. The person paying the note is responsible for investigation of the arrangement and continuation of the endorsement but he is not responsible for investigating the accuracy of the signatures of endorsers.

Part VII - The right to act in case of nonpayment and non-acceptance 
Article 513: The bearer has the right to recourse from the endorser and the maker and other responsible persons in the following cases:

If during the specified time the note has not been paid.

If the payment of all or a part thereof should have been refused.

In case of the bankruptcy of the addressee, regardless of whether the note had been accepted or not; or in case of delay in the payment by the addressee regardless of the order of the Court; or in case the bearer has appealed to the Court and has asked for control of the property of the addressee equivalent to the amount of the note without any actual result.

In case of the bankruptcy of the issuer of the note which was not acceptable by him.

Part VIII - Intermediate

Article 525: The writer or the endorser may introduce another person so that the addressee could, in case of default, refer to him for acceptance or payment. The third person and the addressee, or anyone who might have responsibility due to signing the note (excepting those who accept the note) may act as intermediary. A person mediating for anyone o $f$ the signatories must so inform the person for whom he is mediating within the period of two working days.

Accepting Through Mediation

Article 526: In case the due date of the note has arrived and the bearer has authority to prefer charges, acceptance through mediation may take place. The bearer is free to accept or reject mediation, but if the bearer accepts the offer of mediation, he loses the right to prefer charges against the responsible parties before the due date.

Article 527: The acceptance of mediation shall be written on the note and signed by the intermediary. The person in whose name the acceptance through mediation has taken place shall be explicitly stated. In the absence of such an explicit statement, it is considered to have taken place for the account of the issuer.

Payment through Mediation

Article 529: In all cases where the bearer is entitled to prefer charges, whether during the due date or before that, payment through mediation is possible. Payment through mediation must include all the sum payable. It must be executed at the very latest on the day following the last day specified for the protest of default.

Article 530: If a negotiable note has been accepted through mediation but not paid, the bearer shall write the Protest of default the next day after the last date specified for the Protest. In case the Protest is not made within the mentioned period, the person in whose account the note is accepted and also the subsequent endorsers are without responsibility.

Article 531: The bearer not accepting payment through mediation according to Article 518 loses his right to prefer changes against those who are responsible for the payment of the note. 
Article 532: Payment through mediation for whomever it may be is evidenced by explicitly writing and signing on the note. If the name of the person to whom the payment is to be made is to be made is not clearly written on the not, it is understood that the note is for the writer. The note and the Protest form, in case same has been executed, are given to the person who has made the payment through mediation.

Article 533: On payment through mediation, to whomever it is made, the rights of the bearer and all those responsible to him are transferred to the payee, but that person can not re-endorse the negotiable note. Payment through mediation (from whomever it might be) is a sign of the release of subsequent endorsers. In case there should be many intermediaries for the payment through mediation, the mediation of any one of them who acquits the most persons is preferred.

\section{Part IX - Number of Copies of the Negotiable Note}

Article 534: A Note may be issued in many copies, not different from each other, The text of the copies should have serial numbers. Any copy of the note not having a serial number is considered a separate note. If the text of the note should not have the expression "Only one copy", the bearer can, by agreeing to pay the expense, request many copies. If the note should be in one copy and the endorsement is made on it, and later the bearer gets many copies, he must refer to his previous endorser and this endorser must refer to the endorser before him in favor of the bearer, and the endorsement should go in this way. The endorser must make their endorsements on the new copies.

Part X - Forgery \& Alteration

Article 536: The forgery of a signature in a Note, whether it be of the issuer or of the acceptance, does not affect other signatures on the note.

Article 537: If an alteration is made in the text of a negotiable note, the persons signing it after the alteration has taken place are responsible for the amount after alteration, and those who have signed it before the alteration are responsible for the original text of the note.

Part XI - Passage of Time

Article 538: All cases brought against the acceptant because of the note are without effect three years after the due date. The cases brought by the bearer against the endorsers and the issuer are without effect after one from the date of the Protest made during the specific period thereof (or, if the note should contain the condition of "return without expense", from the due date). Cases brought by endorsers against each other or against the writer lose their effect after six months of the date of the payment by the endorser, or of the date the cases against them were brought.

Article 539: Transaction requiring termination at a specified time are valid only in case of those persons who will take advantage of them.

Part XII -General Regulation 
Article 540: If the due date of a negotiable note falls on a holiday, payment is made on the following working day, and also all transactions relating to the note, especially the matter of its presentation for acceptance and the writing of Protest, should take place on a working day. In case one of the above-mentioned transactions should fall due in a period the last day of which is a legal holiday, the period is prolonged until the first working day after the holiday. Holidays occurring in the period are counted

Article 541: The first day of the time specified legally according to a contract is not counted in the above-mentioned period.

Article 542: The responsibility of persons in a negotiable undertaking is according to the laws of the nationality of the persons involved.

Article 543: All promises concerning a negotiable note are subject to the laws of the country in which the promises are made.

Article 544: The Protest or any action taking place to protest the rights initiating from a negotiable note or the uses thereof are subject to the laws of the country in which the actions take place.

Subchapter 8 - Promissory Notes

Article 545: A commercial promissory note has the following points:

The expression "Promissory Note" on the document in whatever language is written.

The unconditional payment of the specified amount.

The due date of the payment.

The place for the payment.

The name of the person is whose behalf or on whose order the payment is to be made.

The place and date of the writing of the promissory note.

The signature of the person issuing the promissory note.

Subchapter C - Checks

Part I - Checks

Article 549: A check should have the following features:

The word "check" in the next of the document.

The order of effect the unconditional payment of the sum

The name of the payee.

The place of payment

The record of the place and date of issue of the check.

The signature of the person issuing the check. 
Article 550: A document not containing any one of the criteria of Article 549 is not considered a check except in the following cases:

If the payment is not mentioned in the check, the address written beside the name of the addressee is considered the payment as well as the living place of the addressee.

If the place at which the check has been issued is not mentioned, the place beside the name of the person issuing the check is considered the place of issue.

Part II - Endorsement

Article 559: Any check except the one for the bearer is transferable with endorsement. If the writer should use the expression "Not transferable or anything to imply this idea, the check can not be transferred by endorsement. A check may be endorsed to the addressee, to the writer, or to any other person. These persons may in turn re-endorse the check to others. With endorsement, all rights resulting from the check are transferred.

Part III - Guaranty

Article 62: The regulations of Article 499 through 501 concerning the guaranty of negotiable note are applicable to the guaranty of check as well.

Part IV - Presentation and Payment

Article 563: A check is payable when presented. Any condition contrary to this is not accepted.

Part V - Cancelled Checks and Checks Transferable to Accounts.

Article 570. The writer or owner of a check can cancel it. Cancellation is effected by placing two parallel lines of the check. It is either public or private, depending on whether either a blank or the word banker or equivalent appears between the lines or the name of the banker is written between the two lines. Public cancellation is changeable to private but vice versa through the erasure of the line and the word banker or the name of the banker is not allowed.

PART VI- Action in Cases of Nonpayment

Article 573. In case of refusal of payment the owner of the check can refer to the endorsers' writer and all those responsible. The owner can present any one of the following reasons for refusal to pay:

Protest by a formal paper

Endorsement of the check by the addressee together with the date.

The certification of the commercial code to the effect of presentation of the check with the recorded date.

Part VII - The Number of Copies of the Check 
Article 579: It is possible to issue a check in many copies. In such case every copy must bear the same number and it should be mentioned thereon how many copies of the check there are, and should be paid on account of the first.

Article 580: When payment has been made on the first copy, other copies lose their effect.

Part VIII - Fraud and Alteration

Article 581: The contents of Articles 536 and 537 concerning fraud and alteration are applicable to checks as well.

Part IX - Passage of Time

Article 582: Suits brought by the bearer against the endorsers and the writer are cancelled six months after the end of the period of presentation, and also the suit of each of the responsible parties in cancelled six months after date of payment. The contents of Article 539 are applicable to checks as well.

Article 583: The provisions of Articles 540 and 541 dealing with negotiable notes and promissory notes are also applicable to checks.

Subchapter D - Loss of Commercial Documents

Article 584: If the bearer of a commercial document should prove his ownership by discontinued endorsements, he does not have to return the amount he has received unless it is proved that he had received this through illegal means.

Chapter IV - Commercial Agreements

Subchapter A - General Regulations

Article 590: If two or more persons should have, collectively, a commitment to third person during a business transaction, whether of commercial nature to one or all of them, unless otherwise stated in the contract they are collectively responsible. This same order is applicable to persons guaranteeing a debt.

Article 590: If, because of some commercial contract, an amount is due in foreign currency not legally used in Afghanistan, the amount may, at the end of the due period, be changed into Afghanis. But if, during the contract, the payment should explicitly be provided to be paid in the foreign currency, or there should be a statement to this effect, the payment in the same currency must be recognized.

Article 591: A person not fulfilling his commercial commitment through importer delivery or delay, after being warned officially or by registered letter, must compensate for the loss in profit suffered by the person to whom he is committed. Uncontrollable reasons are exceptions to this order. 
Article 592: If the person has committed himself should break his commitment, or should not fulfill the commitment that is to be executed at a particular time or during a particular period, or if the subject of the commitment should not execute an act and he executes same, suit to recover the loss may be filed without notice.

Article 593: If the amount mentioned in the contract as "Compensation for Loss" exceeds the amount of the profit that would have been received by the person to whom the commitment was made, the Court can not reduce that amount. Unless otherwise stated explicitly in the contract, the person specified in the name of compensation for loss for the execution of the commitment. If the loss to be paid by the person to whom the commitment had been made should exceed the amount specified as compensation for loss, unless otherwise specified explicitly in the contract.

Article 594: If the commitment is not executed because of reasons which could not be anticipated, or because of shortcomings of the creditor, or there is a waiver condition accepted by the person to whom the commitment has been made, the person who has made the commitment is in no way responsible for any kind of payment as compensation for the loss.

Article 595: The down payment is considered valid evidence that the contract has been made. In case of both parties executing their commitments, the down payment is taken into accounts. If a contract should be broken with consent of both parties, or for a reason that doesn't involve compensation for the loss, then the down payment is returned to its owner.

Article 596: Unless otherwise stated in the contract, or used in the commercial custom, the party who through his own shortcomings doesn't fulfill the commitment is not entitled to claim down payment paid by him.

Article 597: If one of the contracting parities in absence of payment or promise of payment should, through agreement, reserve the right to initiate a conditional sum for himself, the party can not execute the initiated right until the agreement of acceptance has been fulfilled.

Article 598: Interest on commercial debts is calculated after the specified period, or, of the date should be specified, from the date indicated.

Article 599: A person having the authorization of a merchant who has made a transaction for a merchant or non-merchant that was necessary for his business or beneficial to him has the right to ask for a return due to the transaction he has made.

He moreover is entitled to request the amount he has given in advance for fulfilling an action or receiving profit, and the expenses he has incurred, with interest, starting from the date of the expense.

Article 600: Interest in commercial transactions may be determined on the basis of the consent of both parties.

Article 601: A commercial contract is to be executed in the place mentioned in the contract. If it should not be mentioned in the contract, it should be executed in a place that may be determined 
on the basis the nature and purpose of the business. If the execution place is not mentioned in the contract, and also can not be inferred, the person who has made the commitment must execute his commitment where his place of business is located, or, if he does not have a place of business, it may be executed at the place where he lives.

Article 602: Settlement of the amount involved in the contract, unless otherwise explicitly or by inference stated in the laws, should take place where the place of business of the creditor is located, or if he does not have a place of business it should take place in his private residence. Debtors are not entitled to claim expenses and losses incurred through settlement.

Article 603: The request for execution of a promise whose time of execution is not specified in the contract is possible at any time, but if the execution of the promise should subject to the passage of a period according to tlo9cal custom, the person who has made commitments can not be made to execute the promise before the end of the mentioned period.

Article 604: If it should be a condition that the promise be realized during a period explicitly or implicitly specified, in the end of that period should correspond to a public holiday, it should be executed at lest one day before. If the debtor has permission to make payment before the date due, provided custom should not be against it, he can not reduce or discount the debt without the permission of the creditor.

Article 605: If there is nothing explicit concerning the kind and quality of goods whose receipt has been promised, the person who has made the promise can give goods of average kind and quality but as he does not have to give the best quality, in the same way he is not allowed to give the worst.

Article 606: In case a promise binds both parties it is not necessary for one particular party to execute his part before the other has, but if one party is given priority in executing his duty explicitly by the contract, or by the nature of the business, or by current custom, he must execute his part even though the other has not.

Article 607: In case one of the parties executes his part and the other do not, the person who has executed can send a note to the one who has not to the effect that if he does not fulfill has responsibilities during a specified period the contact will be invalidated. After that, he can refer to the Court and request invalidation of the contact. The party who has referred to the Court to validate the contract can not request the fulfillment of the contract. Just as after the request of validation the Court can not give time to the defendant to execute his responsibilities, in the same way the Court can not accept the proposition set forth by the defendant regarding the execution of the promise. If the invalidation of the contact depends on a condition, or if for its taking place a period is determined explicitly or inferentially, after the realization of the condition or the passage of the period, no party is required to agree to execute the promise requested by the other party.

Subchapter B - Commercial Contracts

Part I - Contract Procedure 
Article 608: In order for a commercial contract to take place, the consent of both parties is sufficient. Preparation of a contract or other ceremonies is not necessary.

Article 609: If it is required by the law that the contract be written on a special form, or if both parties delay the contract for certain ceremonies, the contract can not take place without that form or before those ceremonies. If both parties have agreed on the preparation of the contract, it is understood that the execution of the contract has been delayed for preparation of the contract. If the contract is not prepared but it is proved that both parties have agreed to make the contract, absence of the prepared contact is not an excuse for not executing the contract.

Article 610: If it has been necessary to specify a period for acceptance, acceptance can not take place before the end of that period, even if both parties agree. If an agreement should be necessary, without specifying a period of acceptance the validity of acceptance is conditional to the immediate acceptance and presence of the parties concerned. A contract made by communication means, such as telephone, is as if it had take place in the presence of the parties concerned. A contract made by communication means, such as telephone, is as if it had taken place in the presence of the parties concerned.

Article 611: When the act of acceptance takes place in writing, if the period is not determined, the contract initiator can not disregard the act of acceptance before the termination of the time necessary for thinking and positively answering by the acceptor.

Article 612: The acceptance answer should be sent during a specified period that should reach the contract initiator. If the answer comes after this period, the contract does not take place unless it is found that the acceptance answer has been give during the specified required period. The contract initiator must at once inform the other party about the delay in receiving the answer being responsible for the contract not taking place. Otherwise, the contract is valid.

Article 613: Lack of response by the other party does not imply acceptance. In case two members have permanent commercial relations, or if one of them requests the other to execute certain transaction is his name, the decision made by the person referred to should at once be made known to the opposite party, or else the lack of response is considered as acceptance. They party rejecting the initiated proposition has to take special steps about the goods sent to him when the proposition was made, as mentioned in Articles 762 and 763.

Article 614: If the acceptance's answer is not in agreement with the proposition, the contract does not take place. In such case, the acceptance necessitates another proposition.

Article 615: In order for a telegram concerning the proposition or the acceptance to the be acceptable, it is necessary that it be proved that it contains the signature of the sender or has been sent with his consent.

Article 616: In case the proposition is made in writing, the contract takes place from the date of arrival of the acceptant's answer to the proposal; but if the proposer should be informed before 
the arrival of the answer or during this time of the rejection by the acceptant, the proposition is without effect.

Article 617: A contract taking place by communication is valid from the date the acceptance answer has been sent. Just as mentioned in Article 613, in case it is not necessary that acceptance be explicit, the contract is in effect from the date the proposition has reached the addressee.

Article 618: The death or disqualification of merchant does not necessitate the invalidity of his proposition in acceptance concerning his commercial transactions unless otherwise explicitly mentioned or understood from the nature of that transaction.

Part II - Interpretation of Commercial Contracts

Article 619: If the meaning of the statement of a commercial contract should be explicit and logical, the apparent meaning is assumed. Otherwise the real purpose is honored. If the content of the statement is inconsistent with that of the contract, the interpretation of purpose is held applicable.

Article 620: In case a statement has many interpretations, the common purpose is determined from the contents of other contracts, to custom, or the transactions and circumstances prevailing at the time of the preparation of the contract, or according to previous applications.

Article 621: In case the statement should have unusual and common meanings, it is interpreted as according to which meaning it is closer to.

Article 622: In case the statement of the contract should be interpreted with many meanings, and according to Article 620 the real purpose of both parties should not be determined, the contract is interpreter against the person promising and for person to whom the promise has been made.

Article 623: Recognition is given to commercial custom as well as to legal orders in commercial transaction unless otherwise explicitly agreed to by both parties.

Part III - Means of Proving Commercial Contracts

Article 624: The Court rules as to the proof of the contract on the basis of commercial documents and commercial contracts. Unless otherwise stated in this law, witnesses and evidence are used to the benefit of the Court and the statement of plaintiff has no bearing.

Article 625: The return of the document to the debtor, unless proved otherwise, is considered as the reason for payment.

Article 626: When documents or commercial transactions, the validity of witnesses, may issue an order.

Article 627: Confession or admission is not qualified. Therefore, it is necessary that the statement made by the defendant be either all rejected or all accepted. 
Article 628: if a written statement does not exist, and a person has either explicitly or inferentially accepted a bill or a note, it is understood that he has accepted the contents therein also. If a person takes a bill, and if he did not then protest its contents, it is understood that he has accepted the contents therein.

Subchapter C - Commercial Price

Part I - General Regulations

Article 629: The consent of both parties regarding the property and the price is considered to be acceptance of the price. To send the current price and the catalog or the offer to sell without specifying the nature, quantity, and price of the goods is not considered to be a proposition.

Article 630: If a seller sells the property of others, the buyer can not be their owner, but the seller has to either buy the goods and turn them over to the buyer or, if additional loss had been suffered, he has to compensate for the loss incurred.

Article 631: If a merchant should sell or receive the movable properties of another person, in case the buyer does not have the facts the buyer is the owner of the property sold, but if it is proved that the property sold was from a theft or was lost, the ownership of the buyer is cancelled.

Article 632: The price of commercial goods which was unknown at the time of contract and which was established at the time of delivery is considered applicable.

Article 633: If, during a contract, the destruction and loss of goods concerned should be anticipated by both parties, its price can be determined but in case of realization of the anticipated event the buyer is not entitled to return of his payment.

Article 634: All expenses concerning the receiving of contracted property, such as weighing and measuring, related to the seller, and all the expenses concerning the delivery such as expense of transportation relate to buyer, unless otherwise expected by the contract or commercial custom.

Article 635: If it should be necessary that articles sold be sent from another place to the buyer, and there is no condition made by the buyer concerning the delivery, in such case the seller takes steps towards the selection of transportation means for the properties and their protection as the buyer would.

Article 636: To send an article of goods sold to the residence of the buyer by the seller, or to send it to another place mentioned in the contract, is understood as a delivery, but I $f$ the seller should send the sold property with a person and advise him that the seller must pay the price and other necessary provisions, or else he is not to be given the goods, in this case the sending of the goods is not considered as delivery. 
Article 637: To send a sold article or, with the consent of the seller, to place the mark of the buyer on the articles sold, provided the property is transported across land, ocean, or river, is considered as delivery

Article 638: The buyer who has purchased the property the quantity of which is determined from the wholesale point of view, can not be made to receive part of it. But if the buyer should have accepted partial shipment, he can make the seller deliver the balance due, or for not having received the balance suffered by him through this deed.

Article 639: The buyer may request the invoice for the property sold, or if it has been paid for, its recording on the invoice.

Article 640: After the completion of the contract, the loss suffered through the property sold, even if it should be accidental, is the responsibility of the buyer, but the loss resulting from the shortcoming or fault of the seller or the defect of property sold relates to the seller.

Article 641: After the completion of the contract, the loss suffered through the property sold relates to the seller in the following cases:

If the property sold is not specified and there are not distinguishing marks to differentiate if from other properties of the same kind.

If the property sold, whose weighing and measuring is necessary for the transfer, is changed or destroyed (but if the buyer in spite of warning to be present either himself or through a representative for weighing and measuring does not do so, the loss suffered relates to him).

If the transfer of a property sold should be conditioned for future delivery.

In case the buyer is ready to receive the goods sold but the seller, in spite of the notice doe not take action to deliver the item.

Article 642: The loss suffered through mishandling of articles by the transportation agent or commission agent after the property has been given to them relates to the buyer.

If the transportation of goods should be subject to special conditions, the seller must follow these conditions. Otherwise he will be responsible for the loss suffered by the buyer. If the place where the property is sent should be considered by both parties as the delivery place, in such case the loss suffered to the property while in transit relates to the seller. If the seller only undertakes to pay the expenses for transportation, the place where the goods are sent is not considered the giving place.

Article 643: The price should be specified, or there should be a way to this end. In case the price is not specified, and the goods have not been given either, the current price at the place and time of the contract is taken as base. If the current rate at the place and time of contract be varied, the buyer has to pay the average rate.

Article 644: The right to determine the price by third person is allowed by contract. If the third person for any reason did not settle the price, the buyer must pay the current rate, or if there 
should be a varied he must pay the average current rate. If there is not a current rate, the price is set by the Court.

Article 645: If the buyer has not made payment, or he goes bankrupt during the period between the date of contract and delivery, even if the seller should have deferred the time of payment but has not received reliable guarantees, the seller has the right not to make delivery, the seller has the right not to make delivery.

Article 646: If settling the price is conditioned to weighing the property sold, the weight of the container is subtracted unless otherwise stated in the contract or used by the customer. If the weight of the container should be determined on the basis of real weight of the property sold, or on the basis of some other standard, or part of the weight of the property sold is reduced as the weight of the container, or if the price of the destroyed and useless part of the property sold which is given is reduced, this is possible through the contract, or, if a contract does not exist, through the current local custom.

Article 647: Prior to the full payment of the goods, the condition of non-transference of ownership to the purchaser by the seller is valid. When the goods are delivered, the cost is payable by the purchaser from the date of delivery.

Article 648: Unless otherwise specified in the contract the average rate of the place and times of the contract existing in the market or the stock exchange is taken as standard. If this arrangement is not possible, the average rate of the sales of these same kinds of property at the time and place of contract is accepted.

Article 649: The interest on the price of the property sold in the name of compensation for loss is calculated from the date the property has been given, but if the buyer has refused to receive the goods the interest is calculated after the date the information has been sent to effect the receiving by the buyers.

Article 650: If the execution of the commitment is divisible in many ways depending on the nature of the contract, or the purpose of both parties or the property sold, and if one the parties should not have fulfilled his commitment, the other can invalidate the contract.

Article 651: If a false takes place on the basis of a sample, it is the duty of the seller to prove that has provided identical goods, but if the sample should be destroyed while in the hands of the buyers, then to the sample.

Article 652: It is permissible for a buyer for examination and experimentation, and approval of the goods.

Article 653: If property is given to the buyer for examination and experimentation, they buyer must, on the basis of the contract, or in the absence of same, during a period specified by custom, express his acceptance or rejection of the property sold.

If there is no period specified in the contract or by custom, the seller specifies a reasonable period and invites the buyer to either reject or accept the property sold during that period. If the 
buyer does not announce his decision during the prescribed period, it is understood that he has accepted the property sold. If the buyer des not state his rights in the matter explicitly, and if he has paid the price of the goods in full or in part, or if he has received the property sold in a manner different from the receiving necessary for experimentation, the sales is complete.

Article 654: In a sale taking place according to Article 652, if the buyer has not expressed his decision of acceptance or rejection or during a prescribed period by contract or custom, the sale is not considered to have taken place. If no period is specified in the contract or through custom, the seller specifies a reasonable period and invites the buyer to use this authorized period. If a buyer is silent during this period, the sale is considered not to have taken place.

Article 655: If the sale is in accordance with conditions laid by contract and the law, the buyer must receive the property sold during the period set forth in the contract or by custom. If the buyer does not fulfill this obligation and has paid the price, the seller can, after warning the buyer about the matter, request the Court to appoint a responsible person to guard the property sold. On such request, the Court at once appoints a responsible person without sending for the buyers.

If the appointment of a caretaker or if the delay in receiving goods should cause a loss, it should be compensated by the buyer. If the nature of the property is such that it can not be trusted to other persons, or if in order to guard the property the expense is more than the price of the property, or if it is necessary to rent a storage place, the seller can, after relaying this information to the buyer, on the basis of Court permission, sell the goods openly (Auction). The money received from such sale by the seller, after deduction of the sales expenses, should be put in a bank in the name of the buyer. If there is no bank, he can deposit this money with Court permission in another safe place. After the property or price thereof is deposited in a safe place, the information in at once relayed to the buyer by the seller.

Article 656: In case the buyer does not pay the price during a specified period set forth in the contract or by custom, just as the seller is entitled to claim the price so also he is entitled to inform the buyer through registered letter to fulfill his commitments within the specified period set forth by the seller. If the buyer does not pay the price during this period, the seller can, according to Article 655, sell the goods, and if the property sold has a current rate in the stock exchange or in the market, the seller can, without having to sell the goods committed for selling, ask the difference between the sales price and the price existing at the end of the period in the stock exchange or the market from the buyer.

Article 657: In case the seller does not give the goods to the buyer during the period set forth in the contract or by custom, the buyer shall invite the seller, through registered letter or otherwise, to have the goods ready for delivery. If at the end of this period the seller does not deliver the goods, the buyer can appeal to the Court and request invalidation of the contract together with the loss suffered and the profit which he has been deprived of. If a buyer wishes, he can buy the necessary goods either directly or through a Court from a third person, and if the price paid by him should exceed that which would have been paid for the goods committed for sale before, this additional price can be claimed from the first seller. In case the property committed for sale should have a current rate in the market or in the stock exchange, the buyer can, without buying 
the goods, ask for the difference of the rates between the price of the goods committed for sale and that used currently. In this case, as well as in the case where he buys from a third person, the buyer is entitled to protect his rights concerning the loss he has suffered according to Article 591.

Article 658: If in the sale according to the specifications, or because of the kind and nature of the properties committed for sale and the purpose of the purchase, the buyer and the seller must necessarily execute their commitments during a specified period, and if, at the end of this period, they have not executed their commitments, the other party can, because of the commitment not having been executed without informing, according to Articles 656 and 657, claim the invalidity of the contract and compensation for the property loss, but the party authorized t invalidate the contract, who may want the commitment to be executed exactly, must, before the end of the period, request the execution of the promise.

Article 659: In commercial sales, if there should appear a deficiently or defect in the property sold, or disagreement to the terms of the contract, or the sample or the law, the buyer must, within four days, relay this information to the seller, or else after having received the goods he or his agent must examine the goods during a period of two weeks after receipt. If a deficiency in the goods or a disagreement to the terms of the contract rights, must during the period of two weeks, or immediately if the deficiency is discovered at once, inform the seller of the matter or else it is assumed that he has accepted the goods as is.

Article 660: The buyer has the right to sue the seller because of defects in the goods sold or disagreement with the contents of the contract, or law, or disagreement with the simple. This right holds for six months from the date delivery has been made. To increase or decrease this period in the contract is not permissible.

Article 661: If the non-conformance of the property sold with conditions set forth in the law or the contract or with sample should be understood to be a result of misrepresentation on the part of the seller, the contents of Articles 559 and 560 are not applied to it.

Article 662: In case the buyer according to Article 659 should find defects in the property sold, or if he should not find the property sold to be in accordance with the terms mentioned by the contract or law, or the sample, he can first refer to the seller and invite him for examination. If the seller does not appear during a reasonable period, the buyer can appeal to the Local Commercial Court shall on this basis make the necessary ruling.

Article 663: In case property sold has been sent to the buyer from another place, even if the buyer has referred to the seller according to Article 659, the seller must store the property sold at the expense of the seller or delegate it for safekeeping according to Article 655 to a trusty person. If property committed for sale is not of the kind to be stored, or if it is easily perishable, or if the fee for safekeeping is higher than the price of the goods, or it is related to the payment of the storage fee, the buyer can sell the goods according to Article 655.

Article 664: In case goods sold are not in accordance with terms mentioned in the contract or the law, the buyer is free to choose between the invalidity of the contract or request from the Court that the difference of price and loss be adjusted. 
Part 6

Howalla Talabat (Demand Drafts)

Article 711: A creditor can, without approval of his debtor, assign his [right to collect a] debt to another person unless prohibited by the nature of the transaction or the conditions of the contract. A person assigned the debt holds, from the date he has been delegated, shall legally be [the same] as the original Claimant. If there is no provision in the text of the document concerning non-delegation of the demand draft, and a third person should accept the order, then a debtor cannot take the attitude that he need not pay the third party on presentation of the demand draft.

Article 712: Assignment of a demand draft which presently exists but which will be realized in the future is permissible.

Article 713: A demand draft is not honored until it has been put in writing.

\section{Current Account}

Article 721: Current account is a contract on the bases of which both parties agree to make their claims from each other in person regardless of whether resulting from cash or from properties whose ownership is transferable. The account is item by item treated as debit and credit and the balance from each of the parties.

Article 722: The following are the regulations concerning the contract of a current account:

1. The ownership of the properties registered in the debit account is transferred to the receive. 2 . In case, before the contraction of the current account, a transaction has taken place between the parties as the current account, unless otherwise specified the transaction is considered to have been renewed.

3. A commercial document can only be treated in a current account when its payment is positive.

4. The balance of the debit and credit account is payable.

5. The amount recorded in the credit columns of a person from that date when in his favor is credited to his account, and when in his disfavor is debited to his account.

Article 723: If the return from the commercial document mentioned in item 3 of Article 722 should not be collected, it should be returned to the owner and erased from the account.

Article 724: The extension of a current account between two parties does not prevent the request for commission and other minor expenses.

Article 725: A current account is closed on the date specified in the contract or by custom and the difference between debit and credit is contract or by custom, and the difference between debit and credit is established. If there is no such date in the contract or by custom, each year the end of Hoot is considered as the date for the closing of current accounts. 
Article 726: the balance established from debit and credit is subject to interest from the same date.

Article 727: Both parties can arrange to add the interest to the capital and specify the time of balancing the amount in interest and specify the commission amount.

Article 728: Cash and goods given solely to be spent for a specific or a separate purpose do not enter into the current account.

Article 729: The items of debit and credit in the current account are not analyzable. Before the close of the current account, neither of the parties is considered as creditor or debtor,. The status of the claims of both parties is only decided upon termination of the contact.

Article 730: Cash repayments and merchandise will be reliable in current accounts only if the remainder of the accounts at the time of settlement are recorded in favor of the interested party.

Article 731: Current account contacts are legally invalidated due to the following reasons:

1. Termination of the specified period of the contract.

2. With consent of both parties.

3. Invalidation of the contact by one of the parties provided it is not prohibited in the contact.

4. Bankruptcy of one of the parties.

Article 732: In case of the death or incompetence of one of the parties, the other party is entitled to apply to the Court to ask for the invalidation of the contact for current account.

Article 733: The contact of the current account ca be proved only through commercial documents.

Article 734: Registration of debit and credit in the current account does not invalidate the right of contract which results in debit and credit, or the right which both parties have related to the case in defending this matter. If a contact or transaction is discarded, the item relating to it from the current account is eliminated. If there is a different condition in the contract, that condition is followed:

Article 735: Cases concerning liquidation of the current account or the remaining interest determined by the consent of both parties or the law or the repetition, mistake, or the entry of an incorrect item, are invalidated after five years.

Subchapter 9 - Commercial Agencies

Article 760: The function of commercial agencies is the execution of commercial transaction in the name and account of the person for whom the agent works. Commercial agencies may not work without compensation.

Article 761: Even if a commercial agency should include general terms and interpretations, it can not perform non-commercial activities unless there exist special stipulations. 
If an agent has requested direction concerning certain matters from the person for whom he works, the agent also has authorization as far as other aspects of the same business are concerned.

The agency is authorized for a specific business. Other matters necessary for the execution of this business are included without being separately mentioned.

Article 762: A merchant who is given authority to act as an agent is free either to accept or reject it, but in the case of rejection he must:

1. First, report the matter without loss of time.

2. Until such time as news of the rejection reaches the person who has asked him to act as agent, he should take proper steps to safeguard that persons property. Otherwise he will be required to compensate for any resulting loss.

Article 763: After receiving news of the rejection, if the person does not during a period proportional to the distance involved appoint another person as his agent, the agent can refer to the Court, according to Article 655, and request the appointment of a reasonable person to safeguard the property. Moreover, he may request permission to sell as much of the property as necessary to compensate for the expense which he has incurred.

Article 764: If the agent has definite evidence concerning property loss incurred during transportation, he should, for the purpose of making possible suit by the owner of the goods against the transporter of the goods, reveal the losses and take necessary feasible steps to safeguard the property. In case there exists a risk of destruction of all property, the agent should sell the goods with permission of the Court, according to Article 655, and he should at once report the matter to the person for whom he is working. Otherwise the agent will be held responsible for loss suffered through his negligence.

Article 765: In case properties sent to the agent for sale are easily perishable or subject to changes which might result in reduction of the price, and if there is not enough time to get the owner's permission, or if the owner himself should delay in giving an answer, the agent can sell the property according to Article 655, with permission of the authorized Court.

Article 766: The agent must relay all circumstances causing modification or elimination of properties to the person for whom he works.

Article 767: The agent is responsible for losses suffered to articles with him belonging in the account of the person for whom he works only if the loss is for reasons other than extraordinary circumstances or uncontrollable reasons or because of defects existing in the properties themselves.

Article 768: The agent must, during a reasonable and logical period, send the money to the owner. Otherwise he must pay interest from the same date or, if necessary, pay the losses suffered separately. 
Article 769: The agent must deviate from the explicit and final direction of the person for whom he works. Otherwise, he will be held responsible to compensate for loss suffered through the deviation, but if the execution of a transaction by order of the owner should result in a total loss for the owner, the agent can, with permission of the owner, delay the execution of the transaction.

Article 770: Transactions not accompanied by explicit directions of the person for whom the agent works may be delayed until arrival of directions from the person for whom the agent works, but if haste is indicated for the transaction and sufficient time is not available to receive the permission of the owner, or if the agent has permission to take action under prescribed terms, in such case he may act with initiative in the execution of the transaction.

Article 771: The agent must at once inform the person from whom he works of the execution of transaction. If an agent has deviated from his agency instructions, it is understood that the person for whom an agent works has agreed to the deviations in cases where the person for whom he works has not delayed answers during the necessary time.

Article 772: If an agent should receive an amount of money in the name of the person for whom he works, and does not use this money for the specified purpose, he is required to compensate for the loss incurred through not fulfilling his obligation, just as he is responsible to pay interest on that money from that date. If misrepresentation and fraud have been used, he is also subject to punitive actions.

Article 773: If a third person making a contract with an agent should ask for credentials of his agency, the agent must present him with such credentials. Otherwise third persons do not have to execute the contract. However, if the agent should prove that during establishment of the contract the third persons knew of the directions to the agent from the person for whom he works, they can not withdraw from the contract.

Article 774: If the agency of a person who acts or represents another person should not be positively established, or the transaction he has made is not approved by the person for whom he works, he is personally responsible for that transaction.

Article 775: The person for whom an agent works must provide the necessary agency authorization to the agent unless otherwise expected in the contract.

Article 776: The agency fee, in case it is not mentioned in the contract, is determined by the Court according to custom, circumstances, and the condition of the agency.

Article 777: Demand of agreement from a principal in regard to the work of his agency are applicable in cases where demands for advance sums, debts, and drafts have been issued, guaranteed goods via the agent. Or the payment and fees for agency for other sums in respect to guarantees of agency have been loaned; and services have come into existence. If the goods of his client are sold by an agent, incurred expenses can be collected from the price of the goods. 
Article 778: In order for reimbursement mentioned in Article 777 to be made, the agent must inform the person for whom he works, through the Court, of his claim, and include in this notification that if the debt is not settled during a period of five days he will take action to sell the properties having priority. The person for whom the agent works ha the right to protest this notification and invite the agent to Court. The person for whom the agent works must, during a period of three days from the date he has been notified, inform the agent of the protest to the court.

If the person for whom the agent works does not have an address in the locality of the agent, the duration of the protest is extended as follows:

If the residence of the person for whom the agent works is located in the region of the Court, the protest period in 20 days, but if he lives in one of the provinces the protest period is 40 days.

If the person for whom the agent works lives in a foreign country, the protest period is that used in legal trials.

Article 779: In the case of expiration of the period or rejection of the protest, the agent can, according to Article 655, sell the properties under discussion. In case of appointment of many agents for the execution of the same business, if their joint action is not explicitly stated, each of them, in the absence of others, is authorized to execute the transaction. If their joint action should be stated and some of them should not have accepted the agency, those having majority can accept the agency and execute the transaction.

Article 780: if an agent is dismissed without logical reason by the person for whom he works, or if the transaction that was undertaken by the agent should not be completed because of his registration, the party causing this situation is responsible to compensate for loss suffered by the other party.

Article 781: If the agency should cease to exist due to bankruptcy, death, or the fault of the agent of or the person for whom the works, the agent or person replacing him is entitled to any fee in proportion to the completion of the unfinished transaction.

Subchapter 10 - Commission Agents

Article 782: A person who executes commercial transactions in his own name and in the account of the owner of the business for a fee, as his adopted profession, is called a commission agent, and the contract to this effect is called a commission transaction.

Article 783: If the owner of a business has provided for the execution of a matter explicitly in his own name, the resulting contract is subject to the regulations for commercial agencies.

Article 784: In case there is no special regulation in this chapter concerning the rights and obligations of the employer and the commission agent, the regulations relating to commercial agencies apply. 
Article 785: The rights and obligations resulting from the commission business relate solely to the commission agent and not to the employer and the third person.

Article 786: The commission agent should execute the business he has definitely or inferentially accepted. The commission agent who does not fulfill his delegated duties without legal reason, as mentioned in Articles 789 and 790, must compensate for any resulting losses to his employee.

Article 787: The death of the employer does not invalidate the commission contract. His rights and obligations are transferred to his heirs.

Article 788: An employer may not withdraw from such contracts as have been accepted by the commission agent.

Subchapter 11- Transportation Commission Agency

Article 813: A person who, as his vocation, chooses the transportation of commercial goods in his own name and in the account of his employer, is called a transportation commission agent. In cases concerning transportation commission agencies not covered in this chapter, regulations relating to commission contracts and especially those regulations relating to the receipt, safeguarding, and insurance of properties apply.

Article 814: A transportation commission agent can not record in the account of his employer more than the amount he has contracted for with the transport.

Article 815: The transportation commission agent is entitled to claim remuneration only when he has delivered properties to the transporter.

Article 816: The presentation of the transportation document or the waybill substituting for the transportation document, and also the receipt for the deposit of the properties in warehouses, is proof of the goods in the hands of the commission agent. As far as transportation expenses, commission fees, and down-payment money are concerned, these properties are considered, these properties are considered to be mortgaged with the commission agent.

Article 817: In case many commission agents should have consecutively participated in the transportation of property, those agents having participated later must fulfill the rights of the commission agents ahead of them, especially their mortgage rights on the properties that have been transported.

Part IX - Passage of Time

Article 942. Any case resulting from the contract of insurance loses its effect two years from the date of the dispute.

Article 943. After the issuance of this law, the following laws are discarded and replaced by this law: (1) commercial books law: (2) brokerage law: (3) commercial law: and (4) commercial registration law 
Article 944 This law is applicable 2 months after the date it is issued.

Article 945. The authority to execute and apply this law rests with the Ministry of commerce.

We order and ordain the enactment and execution of this law among other laws of the country. Dated 21 Qaus 1334 


\section{PARTNERSHIP LAW OF AFGHANISTAN}

In the Name of Almighty Allah, the Beneficent, the Merciful

CHAPTER 1

GENERAL PROVISIONS

ARTICLE 1. The Basis:

This Law is enacted in the light of the provisions of the Afghanistan Constitution to regulate the affairs related to activities and creation of Partnerships.

ARTICLE 2. Definition of Partnership:

Partnership is an association of two or more persons to carry on business for profit as co-owners, as governed by the Partnership Agreement.

ARTICLE 3. Types of Partnerships:

Partnerships are of the following types:

General Partnership(s);

Special Partnership(s);

Work Partnership(s);

Credit Partnership(s).

ARTICLE 4. Partnership Agreement:

A "Partnership Agreement" is either a written or an oral and implied Agreement among the Partners of the Partnership including any subsequent amendments thereto [that] has no effect on the rights of third parties, unless the third party is aware [of the Partnership Agreement] before transacting business with the Partnership.

ARTICLE 5. Signing of Contracts:

Partnership shall have legal personality and may sign contracts in its own name, and execute transactions and possess movable and immovable properties in the name of the Partnership.

ARTICLE 6. Assets of the Partnership:

The right of establishment, of lease, of name, of title, of patent, of trademark, of models and drawings which are used to perform commercial and industrial services, may be property of a Partnership and title may be held in the Partnership's own name.

ARTICLE 7. Payment of the Capital:

Capital contributions to Partnership shall be made in the following forms:

Movable tangible property (such as cash, articles, and animals);

Movable intangible property (such as royalties, patents, trademarks industrial marks, and commercial credit and goodwill);

Immovable property including, [but not limited to,] real property;

Profits and privileges from the use of movable and immovable properties;

Products and processes;

Commercial credit and goodwill; 
Services performed or to be performed for the Partnership.

ARTICLE 8. Contribution of Capital and Delay in Contribution:

If a Partner does not pay such Partner's share of the Partnership capital, the Partner is indebted and responsible to the Partnership for making the contribution, and shall pay interest on the contribution from the date determined for such contribution [until the time it is paid]. If a Partner's late payment causes a loss to be suffered by the Partnership, the Partner must pay damages for the loss suffered to the Partnership.

ARTICLE 9. Valuation of property:

The value of property, including third-party indebtedness, accepted as capital [contribution] shall be determined by the Partnership Agreement. If it is not determined [by the Partnership Agreement], the current market value of the articles shall be valid. In case such articles do not have a current market value or its price can not be determined on the current day, the value determined by informed individuals [experts] shall be regarded valid by the parties.

ARTICLE 10. Transfer of ownership:

Unless there are provisions to the contrary in the Partnership Agreement, the property accepted as Partnership capital shall be considered the property owned by the Partnership.

ARTICLE 11. Attention to Partnership Affairs:

Every Partner is obliged to pay such attention to the affairs of the Partnership as if they were his personal affairs.

ARTICLE 12. Negligence in [Performance of] Duty:

Each Partner is responsible to the Partnership for any loss that may be suffered by the

Partnership through such Partner's negligence, fault, or deviation of his working authority. Such Partner may not evade the compensation of loss for the reason that it was useful for another case. The Partners may agree to indemnify and hold harmless each other for harms suffered by the Partnership due to negligence of all or specified Partner, to the extent related to their own rights.

ARTICLE 13. Claim of Partners for Wages:

None of the Partners are entitled to claim a wage for the work they perform [for the Partnership], unless receiving a wage is stipulated in the Partnership's Agreement.

ARTICLE 14. Wages as a Percentage of Profit:

Concerning the wage paid out to employees of a Partnership for the services they rendered, if such payment is determined to be partially or totally as a share in the benefits of the Partnership, they shall not be considered as Partners of the Partnership.

ARTICLE 15. Profit and Loss of Each Partner:

Unless [otherwise] provided by the Partnership Agreement, the profits and loss shall be distributed to each Partner proportional to such Partner's capital contributed to the Partnership.

ARTICLE 16. Distribution of Profit and Loss: 
If the manner of distribution of either loss or profit is not contained in the Partnership Agreement, the other is also distributed in the same manner.

ARTICLE 17. Payment of the Profit Limited by the Agreement:

If an agreement between the Partners and third parties restricts the profit to one or some of the Partners, or if it excludes one or some of the Partners from the loss, such Agreement shall be invalid. In this case the manner of distribution shall be considered as unknown and the profit and loss should be distributed among the Partners in accordance with Articles 13 and 14 of this Law. However, in case of a Partner whose endeavors and work is taken as capital in the firm, and the Partnership Agreement provides that such Partner is not affected by the loss of the firm, this arrangement shall be valid.

ARTICLE 18. Preferential Conditions:

In the absence of a [written] Partnership Agreement, each Partner participates equally in the possession of Partnership capital and distribution of profits and losses of the Partnership. If the Partnership Agreement contains a provision governing the possession of Partnership capital, distribution of profits, and losses of the Partnership, such provision shall have preference.

CHAPTER 2

\section{PARTNERSHIPS}

ARTICLE 19. Continuation of Activities:

If a Partnership continues to do business after the expiration of its determined period, it shall be considered as having indefinite existence [thereafter].

ARTICLE 20: Completion of Le gal Existence:

Legal existence of a Partnership shall be established upon the association of two or more persons as co-owners of a partnership and shall be completed upon registration in the Central Registry. A Partnership shall be liable if it carries out any transaction before registration in the Central Registry. In such case the Partnership may not enforce its rights against third parties unless notified in the Central Registry.

ARTICLE 21. General Partnership:

A "General Partnership" is one which is established for the purpose of carrying out economic or business transactions between two or among more persons with collective responsibility. If the capital of the General Partnership is not sufficient to pay the debts of the General Partnership each of the Partners is responsible to pay all the debts of the General Partnership and the Partner, or Partners, paying such debts shall be entitled to receive contributions from the other Partners.

ARTICLE 22. Special Partnership:

A "Special Partnership is a Partnership established under a specified title in accordance with the provisions of this Law for the purpose of carrying out economic and business transactions, in which one or more Partners have unlimited liability (General Partners) and the rest of the Partners have limited liability with a definite capital (Special Partners). The capital of the Partners with limited liability can be divided into shares. 
ARTICLE 23. Work Partnership:

A "Work Partnership" is an association of two or more persons who perform work or fulfill an obligation for another person. The profits of the work of the Partnership shall be distributed between them as agreed by the Partners.

ARTICLE 24. Credit Partnership:

A "Credit Partnership" is a company in which two or more persons agree to buy goods on credit to sell them and to share the profits and losses of the Credit Partnership. Each of the Partners shall be responsible for his specific part.

ARTICLE 25. Terms of the Partnership Agreement:

(1) Partnerships, whether general or special, must include the following conditions, as a requirement, in the written Partnership Agreement:

1. Date of concluding Partnership Agreement;

2. Name, identity, and address of each Partner and if a Partner is another company, the title of that company;

3. Business location and type of business;

4. The fact that the company is a Partnership company;

5. The title of the Partnership;

6. The names of all the Partners who are jointly or severally authorized to acquire legal possession and sign;

7. The capital contribution committed by each Partner, the approximate value of non-cash capital, and the method applied to determine such approximate value;

8. Each Partner's share in loss and profit; [and]

9. If the General or Special Partnership is for a limited period, the date for expiration of its term;

(2) In addition to the conditions provided in Paragraph (1) of this Article, the Partners may

include any other terms and conditions in the Partnership Agreement, which are deemed useful by the Partners.

ARTICLE 26. Duration of Partnership:

A Partnership can either be for an unlimited duration, or for a definite term. Unless the Partnership Agreement specifies a definite term, the Partnership is deemed to have an unlimited duration.

ARTICLE 27. Registration:

"Register" means making recordation in the "Central Registry". For the purposes of this Law, the term "Central Registry" means a Government office under the Ministry of Commerce and Industries where the documents related to companies shall be recorded.

ARTICLE 28. Court:

"Court" means the competent Commercial Court of Afghanistan.

CHAPTER 3

RULES OF PARTNERSHIP

ARTICLE 29. Scope of Application: 
The provisions of this CHAPTER shall apply to all Partnerships covered by this Law, unless otherwise provided for in CHAPTERS 4, 5, and 6 of this Law. In such a case, the provisions [of these chapters] shall prevail.

ARTICLE 30. Damage of Goods:

The partners are as trustee towards each other and the goods of the partnership are like trust to the partner. If the goods are damaged without fault or encroachment of the partner, the partner shall not be liable, but if the goods are damaged due to fault and encroachment of the partner, the partner shall be deemed responsible.

ARTICLE 31. Failure to Pay Share:

Where a Partner has agreed to contribute cash to a Partnership and fails to make such a contribution, the Partner shall be bound, without any judicial demand or announcement, to pay the legal interest accrued as well as to compensate the Partnership for the damage inflicted on the Partnership since the time when the payment of the share is not made.

ARTICLE 32. Equivalent Payment:

If a Partner does not make a promised contribution of property, other than cash, the Partner is obligated to contribute money equal to that portion of the value of the stated contribution which has not been made.

ARTICLE 33. Performance of Action in the Agreement:

(1) If a Partner's contribution is of action or services, the Partner shall either perform the services he had committed or shall contribute money equal to the value of the services.

(2) The share of performance shall be considered paid with the practical performance of the action to which a Partner is committed. In such case, such Partner shall be responsible only for the services he performs for the Partnership.

ARTICLE 34. Contribution of Partner in the Form of Debt:

If a Partner's contribution is in the form of a debt to the Partnership, the liability of the Partner shall be deemed fulfilled when the debt is paid to the Partnership in due time. In case of nonpayment, the Partner shall be bound to compensate the Partnership for the loss incurred from the deferred payment of the debt, in addition to the responsibility which may arise from nonpayment of debt in due time.

ARTICLE 35. Distribution of Shares:

Before liquidation, distribution of shares shall be made at the time and manner provided for in the Partnership Agreement.

ARTICLE 36. Distribution of Unspecified Profit:

Where the share of each Partner in the profit and loss is not specified in the Partnership Agreement, the share of profit of each Partner shall be distributed in proportion to such Partner's share in the capital of [the Partnership].

ARTICLE 37. Determining Profits and Losses in the Agreement: 
The Partnership Agreement may specify the Partners' shares of profits and losses regardless of the contributions of the Partners. Where a provision of the Partnership Agreement fixes the share of profit of each Partner, and does not provide for the Partners' share of losses, such provision shall be valid for determining the share of loss incurred. Likewise, any provision made in the Partnership Agreement for determining the share of loss of each Partner shall also be deemed valid in determining each Partner's share of profit, unless otherwise stated in the Agreement.

ARTICLE 38. Share of Partner Limited to Work and Performance:

(1) Where the share of a Partner is limited to such Partner's work and performance, unless otherwise provided in the Partnership Agreement, such Partner's share of profit and loss shall be subject to the use which the Partnership makes from such Partner's service.

(2) In case the Partner, in addition to rendering of service or performance of action, pays money in cash or something else, such Partner shall be entitled to a share in return to such Partner's action and to another in return for such Partner's contribution other than the service such Partner performed.

ARTICLE 39. Purchase of Goods by Credit:

In a Credit Partnership, the profits and losses shall be distributed in proportion to the property that each of the Partners bought on credit in the account of the Partnership, and guaranteed [the payment thereof], unless the Partnership Agreement provides otherwise.

ARTICLE 40. Administration of the Partnership:

The Partnership Agreement shall require establishment of an administration. Partners may designate persons from the partners or other than Partners to administer the affairs of the Partnership.

ARTICLE 41. Continuation of Activity:

Where on the basis of a provision stipulated in the Partnership Agreement, one of the Partners is assigned with the task of administering the Partnership, such Partner shall continue with administering the Partnership and the performance of those activities which ensures the objectives of the Partnership are realized, provided such [Partner's] activities and the changes such Partner would bring in the Partnership are free from dishonesty. Assigning such person shall be subject to the terms and conditions of the relevant contract and charter, and dismissal of such Partner without any legal reason or amendment of Partnership Agreement shall not be permitted as long as the Partnership survives, unless otherwise provided in the Partnership Agreement.

ARTICLE 42. Approvals of Partners:

Where the Partnership Agreement provides that the decisions should be made by a majority of votes of partners, a partner may perform an urgent work which if not done would cause a great loss to the Partnership, which can not be compensated, and such decisions shall not be rejected, unless the rejection is for performance of an urgent work which, if not done, would cause a great loss to the Partnership, which cannot be compensated.

ARTICLE 43. Majority Consensus in Approvals: 
Unless otherwise provided in the Partnership Agreement, approvals requiring majority consent shall mean consent of a majority of the Partners, regardless of their shares [contribution].

ARTICLE 44. Partner's Participation in Management of the Partners hip:

The right of Partners to participate in management may be limited by the Partnership Agreement, provided that such Agreement may not limit a Partner's right to access information about the management and conduct of activities of the Partnership.

ARTICLE 45. Non-competition and Misuse of Partnership Assets:

A Partner or Chairman of the Partnership may not compete with the Partnership or use Partnership property for benefit or purposes other than those specified in the Partnership Agreement, unless the Partnership Agreement provides otherwise. The Partner or Chairman of the Partnership shall be obliged to exert all efforts in the interest of the Partnership in such a way as such Partner would for such Partner's own personal interests.

ARTICLE 46. Receiving Money or Possession of Property by Partners and Additional Contribution:

(1) Where a Partner acquires or takes possession of some property or a sum [of money] from the Partnership, such Partner shall, without any judicial demand or warning, be obliged to pay the interest from the date such Partner has acquired or taken possession of the property. Such Partner shall also be obliged to pay the compensation for the loss inflicted, if required.

(2) Where a Partner spends some of such Partner's property for the benefit of the Partnership, or makes useful expenditures in good faith in the interest of the Partnership, beyond the amount the Partner has agreed to contribute to the capital of the Partnership, such Partner may get the interest of such [Partner's] sums spent, or paid, from the Partnership since the date when the payment is made.

ARTICLE 47. Payment of Debts:

(1) Where the assets of the Partnership are not sufficient to meet its liabilities, each of the Partners shall be obliged to make contribution proportionate to their shares of losses from their personal properties, for the fulfillment of the debts, unless otherwise agreed to [by the Partners]. Any Agreement by the Partners on their non-liability for the debts of the Partnership shall not be valid.

(2) Creditors of the Partnership can claim against any of the Partners in the Partnership in accordance with the provisions of this Law.

ARTICLE 48. No Suretyship of Partners against each Other:

(1) The Partners shall not be deemed as sureties against each other with respect to the debts of the Partnership for the payment of which they are made responsible, unless otherwise agreed.

(2) In the event of insolvency of one of the Partners, such Partner's share of the losses incurred shall be divided proportionately among other Partners.

ARTICLE 49. Obtaining Personal Debts:

In cases where the Partnership is ongoing (i.e. not liquidated) and where one of the Partners is indebted the creditors cannot demand their rights from the Share which the indebted Partner holds in the capital of the Partnership. However, such demand can be made out of the profits of 
the indebted Partner collected in the Partnership. In the event the Partnership is under liquidation, the creditors can demand their rights from the share of the indebted Partner in the capital and profits of the Partnership to the extent such capital and profits are otherwise to be distributed to the Partner. In any case, the creditors have the right to demand from the Partnership to impose precautionary restrictions on the share of indebted Partner.

ARTICLE 50. Dissolution of the Partnership:

A Partnership shall be dissolved in one of the following cases:

1. Expiration of the period set in the Partnership Agreement;

2. Realization of the objective for the achievement of which the Partnership has been established;

3. Elimination of the whole or most part of the capital of the Partnership as no profit is envisaged to continue with its activity;

4. The death of one of the Partners, or when a Partner is ordered by the Court to be dispossessed, or when a Partner is registered as bankrupt;

5. Withdrawal of one of the Partners from the Partnership when the period of the activity of the Partnership is unlimited, provided that the Partner declares such Partner's intention of withdrawal to other Partners three months in advance. Otherwise, such Partner's withdrawal would be deemed arising from dishonesty or it would be considered inappropriate, unless agreement is made to the contrary;

6. Agreement of the Partners to dissolve the Partnership;

7. Dissolution of the Partnership by Court order; [or]

8. An adjudication of the bankruptcy of the Partnership by the Court, or by agreement of the Partners and creditors of the Partnership to bankrupt the Partnership.

ARTICLE 51. Continuation of the Partnership after Death [of a Partner]:

(1) The Partners may agree that after the death of one of the Partners, the Partnership should not dissolve but shall continue with the heir or heirs of the Partner becoming Partners.

(2) In case of the death, order of Court for dispossession, or bankruptcy of one of the Partners, the Partnership should not dissolve but shall continue among the remaining Partners. In case the Partners do not agree with the heir to continue with the Partnership, such Partner and such Partner's heirs shall not have any right except to the share they hold in the assets of the Partnership according to the daily prevailing price on the day of the event. The share shall be paid to them in cash and such Partner shall not enjoy the rights which may be created later, except what is accrued from the result of the accomplishments of the Partnership prior to such Partner's withdrawal from the Partnership.

ARTICLE 52. Extension of Partnership Activities:

(1) Where the fixed period of Partnership expires, or the activity for which the Partnership has been established ends, and the Partners nevertheless decide to embark on such activity, which is the objective of the establishment of the Partnership, the Partnership Agreement shall be extended year-by-year with the same terms.

(2) The creditors of one the Partners can object to the extension of the activity of the Partnership provided in paragraph (1) of this Article and can stop the Partnership of the indebted Partner.

ARTICLE 53. Court Decision for the Dissolution of the Partnership: 
The Court can make an order [for dissolution of the Partnership] on the basis of a demand made by one of the Partners, by reason of non- fulfillment of the obligations of another respective Partner, or by other rational arguments presented for the dissolution of the Partnership. The Partnership Agreement may not modify this right.

ARTICLE 54. Demand for Expulsion from Partnership:

(1) A Partner may request from the Court the expulsion of any Partner whose activities would result in the dissolution of the Partnership, or cause objection to its extension.

(2) In case the period of the activity of the Partnership is limited, any Partner may request the Court his expulsion from the Partnership by presenting justifiable reasons. In this case the Partnership shall be dissolved unless the remaining Partners agree to the continuation of the Partnership.

ARTICLE 55. Liquidation and Distribution of the Partnership Assets: Liquidation and distribution of the assets of the Partnership shall take place according to the terms and conditions provided in the Partnership Agreement. In case the Partnership Agreement does not have such provisions, the provisions of Articles 56, 57, 58, 59, and 60 of this Law shall be applicable.

ARTICLE 56. Continuation of the Activities of a Partnership until Liquidation:

The authority of the Partners shall be limited to taking concerted actions for the purpose of liquidating the Partnership, but the Partnership may continue until the accounts of the Partnership are cleared and the assets of the Partnership have been distributed in accordance with Article 58 of this Law.

ARTICLE 57. Appointment of Persons for Liquidation of Partnership:

(1) The Partnership shall be liquidated by Partners, or the person or persons appointed by the majority of votes of the Partners.

(2) Where the Partners appoint no person or persons by majority of votes, the Court shall appoint one of the Partners on the request of one of the Partners, as liquidator.

(3) In case of dissolution of the Partnership by judicial proceeding, the Court shall appoint the liquidator and determine the scope of such liquidator's authority and the liquidation procedures, on the demand of interested persons.

ARTICLE 58. Partnership Activities and Sale of its Assets by Liquidators:

(1) The liquidator of the Partnership cannot embark on new activity in the Partnership unless it is complementary to the previous activities and consistent with dissolution of the Partnership.

(2) The liquidator may sell, by way of bidding or otherwise, the property of the Partnership, whether it is immovable or movable, unless such liquidator's authority was restricted during [such liquidator's] appointment.

ARTICLE 59. Distribution of Partnership Assets:

(1) The assets of the Partnership shall be distributed among the Partners after the payment of immediate, mediate, and disputed debts, expenses incurred and loans taken through one of the Partners in the interest of the Partnership. 
(2) A sum [of money], equivalent to the share held in the capital of the Partnership, shall be appropriated to each Partner, according to the Partnership Agreement. In case the value of the share is not described in the Partnership Agreement, such value shall be calculated from the time of delivery, unless the share of the Partner is limited to performance of action and consultation or allocation of a part of [its] property for the benefit of the Partnership or only for profit.

(3) To the extent the Partnership Agreement does not provide for distributions on liquidation of the Partnership, the property of the Partnership remaining after the payment of debts shall be divided among the Partners proportionate to their respective shares.

(4) Where after payment of the sums provided in paragraph (1) of this Article the residual property of the Partnership is not sufficient for the Partners, the shares of the loss shall be calculated and distributed proportional to the shares of Partners.

ARTICLE 60. Application of the Provisions of the Civil Code relating to Jointly-owned Property:

Where there are no provisions with regard to distribution of the assets of a Partnership in this law, the provisions pertaining to the distribution of jointly-owned properties in the Civil Code shall be observed.

CHAPTER 4

GENERAL PARTNERSHIPS

ARTICLE 61. Establishment of Partnership:

Within one month from the date the General Partnership is established, persons establishing a General Partnership must register and advertise a copy of the written Partnership Agreement in the locality where the office of the General Partnership is situated.

ARTICLE 62. Establishment of a New Branch:

If a General Partnership should establish a branch outside the region where it is registered, it shall be obliged to register a copy of the Partnership Agreement in the new registry office as well.

ARTICLE 63. Changes in the Partnership:

After a General Partnership has been registered and advertised, any changes to the General Partnership regarding its title, business location, authorized signing Partners, withdrawal or inclusion of Partners, increase or decrease of Partnership capital, dissolution of the General Partnership before, or continuing beyond the specified period, or amalgamation with another company, must be put in a statement signed by all Partners. This statement must be registered in the relevant office and any other changes may be registered therein.

ARTICLE 64. Prohibition on Using Details:

Information that is to be registered and advertised according to ARTICLE 61, or registered according to ARTICLES 62 and 63, cannot be used against a third person before registration and subject to ARTICLE 61 cannot be used against third person before advertisement, unless the third person has prior knowledge of the facts that require registration. If before registration and advertisement, a transaction has been concluded in the name of the General Partnership, the General Partnership is responsible to the third party. In case the General Partnership has not been 
registered and/or advertised as required by Law and the Partners deny existence of the Partnership, third parties can prove the existence of the General Partnership by whatever direct or circumstantial evidence.

ARTICLE 65. Conducting Transactions in the Name of the Partnership:

If the registration and advertisement of a General Partnership has not taken place during or after the period of time prescribed in ARTICLE 61 of this Law, until Registration of dissolution whatever transactions are made in the name of the General Partnership do not damage the interest of third parties, unless the third parties have knowledge of the dissolution.

ARTICLE 66. Relationships between the Partners:

Relationships between the Partners of a General Partnership are governed by the Partnership Agreement, and the terms and conditions of the Partnership Agreement may be included in writing either in the contract document or the supplementary documents thereof. Where no terms and condition are provided in the Partnership Agreement, the provisions of this Law shall apply.

ARTICLE 67. Delegation of Administrative Affairs of the Partnership: Unless otherwise provided in the Partnership Agreement, the day to day administration of the General Partnership, by majority of votes, may be delegated to one, some, or all of the Partners, or delegated to a person outside the General Partnership. Any person delegated with such authority shall be known as "Manager."

ARTICLE 68. Dismissal of the Manager: If the administrative authority of the Manage $r$ is determined in the Partnership Agreement of the General Partnership, the Partners may limit the Manager's, or Managers' authority, or may dismiss the Manager or Managers only in accordance with the terms of the Agreement, or by unanimous majority [sec] vote of all Partners. If the Manager neglects such Manager's duties, or is unable to administer the affairs of the General Partnership, the Manager may be dismissed by majority of votes upon the request of one or more Partners for cause shown. In case the Partners reject the complaint of Partners in spite of good cause shown, they may refer the matter to the Court.

ARTICLE 69. Decision on the Daily Management, and Major and Important Issues: Unless otherwise provided by the Partnership Agreement, ordinary matters and transactions affecting the purpose and objective of the General Partnership shall relate to the day-to -day administration of the General Partnership. The Manager, or Managers, shall be authorized to take action and determine matters concerning the day-to-day administration of the General Partnership using the same standard of care as making decisions about their own business affairs. Important matters outside the day-to-day ordinary matters, including but not limited to matters such as contributions, price, transfer of substantially all the General Partnerships' immovable properties and other matters which are not included in ordinary activities of the Partnership, must be decided by majority votes of the Partners, unless otherwise provided by the Partnership Agreement.

ARTICLE 70. Payment of Loans taken by a Partner: 
If a Partner should take a loan from the General Partnership, or collects a sum of money in the name of the General Partnership (when the Partnership Agreement does not provide otherwise), and does not pay this sum in due time to the General Partnership, in addition to paying the original sum such Partner shall be obliged to pay interest for the late period as well.

ARTICLE 71. Transfer of Shares:

No Partner is authorized to transfer such Partner's shares to a person outside the General Partnership, whether in part or in full, without the unanimous vote of the other Partners, and any loss incurred by Partners or third parties as a result of such transfer shall be the sole responsibility of the transferring person, unless otherwise provided in the Partnership Agreement.

ARTICLE 72. Non -Acceptance of Other Person as Partner: A person authorized to administer the General Partnership can not accept an outsider as a Partner in the General Partnership or substitute another person for himself in the administration of the General Partnership, without the unanimous approval of other Partners.

ARTICLE 73. Profit from Interest:

The Partnership Agreement may provide for [payment of] interest for the contributed capital.

ARTICLE 74. Access of Partners or Managers to Information:

Partners and Manager are entitled to obtain information on the activities of the General Partnership as well as its financial status and may use the information for the governance of the General Partnership. The General Partnership Administration may refuse to give information to any Partner, or manager, if there is suspicion that Partner is going to use the information to damage the General Partnership. The Partnership Agreement shall include access to information and refusal to provide them, however, the Partnership Agreement may not unreasonably eliminate or restrict such rights.

ARTICLE 75. Decisions on Daily Affairs of the Partnership:

Amending the Partnership Agreement shall be made by unanimous vote of the Partners and decisions concerning the ordinary course of conducting the day-to-day business of the General Partnership shall be made by the majority vote of the Partners, unless otherwise provided in the Partnership Agreement.

ARTICLE 76. Preparation of Loss and Profit Statement of Partnership:

The Partners, or a manager (if the duty is delegated to a manager), at the end of each fiscal year must prepare the profit and loss statement of the General Partnership based on a balance sheet and determine the share of each Partner according to it. Unless otherwise provided in the Partnership Agreement, distribution of all or part of the shares before the liquidation of the General Partnership shall be decided by unanimous vote of the Partners.

ARTICLE 77. Partner Not Required to Pay Compensation for Loss:

Unless otherwise provided in the Partnership Agreement, a Partner cannot be made to complete such Partner's share of the loss of capital until dissolution of the Partnership, but the amount of loss of capital of the Partners may be paid from the profits made in subsequent years. 
ARTICLE 78. Partner's Involvement in Similar Business Transaction and Becoming a Responsible Partner in Another Company:

(1) Unless otherwise provided in the Partnership Agreement or this Law, a Partner may not execute a business transaction separate from the General Partnership's transactions in such Partner's own, or someone else's, account without the unanimous vote of the other Partners. If the Partners of a newly established General Partnership know that one of the Partners, at the time of joining the General Partnership, has been a responsible Partner of another company, and if the Partners do not object explicitly concerning such Partner's separation from the other company, such Partner's Partnership in the [newly established] General Partnership is considered to have been accepted.

(2) If Partners after receiving information about one Partner's partnership in another company or execution of a transaction by him do not object within six months, their right to complain shall be cancelled. However, they shall have a right to request the Court for dissolution of the General Partnership according to the provisions of Chapter Four of this law.

ARTICLE 79. Existence of the Partnership:

A General Partnership acquires legal personality as of the date of registration and advertisement, and as amended by any subsequent amended registration(s).

ARTICLE 80. Relations of Partners with Third Parties:

The Partners' relationship with third parties shall be subject to the provisions of this Law, except where provisions have been made to the contrary in the Partnership Agreement.

ARTICLE 81. Transactions by Agents:

A Partner, manager or person, appointed to represent a General Partnership within the authority delegated to him shall be authorized to sign all legal transactions in the name of the General Partnership and bind the General Partnership. Agents of General Partnerships may also conduct business in accordance with the law. All such agents must act in good faith and honesty. Partners may also perform transactions on behalf of the General Partnership that are agreed upon in the contract and bind the General Partnership.

ARTICLE 82. Responsibility of the Partners:

The General Partners shall be jointly and severally responsible for the debts and commitments of the General Partnership.

ARTICLE 83. Lawsuits:

Any claims about the debts and commitments of the Partnership shall be first brought against the General Partnership. In case it is not possible to file a claim against the General Partnership or if the General Partnership has been dissolved, the claim may be made against the Partners. In this case, the Court upon the request of creditors and based on the cause shown, may order that the General Partnership properties and transactions be managed by the Court until the time needed to settle the accounts.

ARTICLE 84. Implementing Judicial Action: 
The decision of the Court with respect to the operations of a General Partnership shall be binding on the Partnership.

ARTICLE 85. Payment of Creditors' Rights [Debts]:

In case of liquidation of a General Partnership, the creditors of the General Partnership shall have priority over the personal creditors of the Partners as to the property of the General Partnership.

ARTICLE 86. Court Order to the Creditors' Claims:

The bankruptcy of the General Partnership shall not be considered as the bankruptcy of Partners. In case the assets of the bankrupt General Partnership is not sufficient to fulfill the demands of the creditors, the creditors can claim their remaining debts from the Partners. However, if the property of Partners is also insufficient to satisfy the claims, the Partners may be announced bankrupt by the Court.

ARTICLE 87. Partners Cannot Utilize Assets [of the Partnership]:

Partners of a bankrupt General Partnership may not make use of General Partnership assets. However, they may claim [their] other claims from the General Partnership as creditors of the General Partnership.

ARTICLE 88. Non Payment of Claims Related to Debts:

A person indebted to the General Partnership cannot escape the debt if a Partner of the General Partnership is indebted to such person. Neither can a Partner escape the debt such Partner owes to the General Partnership if a person indebted to such Partner happens to owe the General Partnership. But if a creditor of the General Partnership, should not be able to receive such creditor's money from the General Partnership, if such creditor seeks payment from the individual Partners and if the Partner from whom the payment is sought happens to have a personal claim on the creditor of the General Partnership, in that case such Partner can use such creditor's claim to pay the debt of the General Partnership.

ARTICLE 89. Duration of Activities of the Partnership:

Unless otherwise specified by the Partnership Agreement, the duration of the General Partnership shall end upon the death of any individual Partner, or the dissolution of any Partner that is a legal person. In spite of this if a General Partnership's duration is not definite and the nature of its business activities is such as to limit the existence of the General Partnership the duration of the General Partnership shall end on the date of completion of the activities.

ARTICLE 90. Dissolution of Partnership:

A General Partnership is dissolved in accordance with the provisions of ARTICLE 53 of this Law.

ARTICLE 91. Conclusion of Valid Partnership Agreement: If the Partnership Agreement of a General Partnership excludes certain reasons as the causes of dissolution it shall be valid, but if it absolutely excludes all the reasons as the cause of dissolution such provision shall be invalid.

ARTICLE 92. Informing Creditors of Dissolution of the Partnership: 
After the dissolution of the General Partnership, the General Partnership must register the dissolution as a change to its existence and must take reasonable actions to notify its creditors and others having transactions with the Partnership of its dissolution. The General Partnership shall then commence liquidation in accordance with the provisions of this Law. All contracts existing at the time of dissolution, or entered before the Registration of the dissolution and notification of third parties, shall remain valid and binding on the General Partnership and its Partners pursuant to this Law.

ARTICLE 93. Informing the Partners of Dissolution of the Partnership: If a General Partnership is established for an unlimited (indefinite) period, any of the Partner/Partners can, at least six months before the end of the General Partnership's fiscal year, notify in writing other Partners of his/their intention to dissolve the General Partnership.

ARTICLE 94. Court Order for Dissolution of the Partnership:

General Partnerships established for limited or unlimited duration may be dissolved by decision of the Court through the request of a Partner in the following cases:

Non-realization of the objectives of the General Partnership for any reason; Dishonesty of a Partner whether in administrative or accounting affairs; Failure on the part of a Partner to perform the principal duties delegated to such Partner; Misusing the title or the properties of the General Partnership by a Partner for personal benefits; Disqualification and incompetence of a Partner because of a continued illness, or other reasons which will disable such Partner from taking part in the business affairs of the General Partnership; [or] Failure of a Partner to contribute such Partner's agreed upon capital if an earlier demand for payment has been made to the Partner by one of the Partners.

ARTICLE 95. Duration of Partnership:

If the duration of a General Partnership is limited, or if duration depends on the life of one of the Partners, after the death of the Partner or termination of such duration, the General Partnership is considered as existing for a time to complete outstanding business transactions consistent with the provisions of this law on dissolution.

ARTICLE 96. Dissolution of the Partnership because of Death, Bankruptcy or Incompetency of one of the Partners:

If the General Partnership is considered dissolved because of the death, bankruptcy, or incompetence of one of the Partners, the heir of the deceased, the legal financial executor of the bankruptcy or his [legal] counsel or the custodian of the incompetent must, without delay, inform the Partners of the matter. If any unreasonable delay in notification damages the business of the General Partnership, the General Partnership may recover damages from the estate of the Partner causing dissolution unless the General Partnership otherwise knows of the event of dissolution.

ARTICLE 97. Continuation of the Partnership after Death or Voluntary Withdrawal of a Partner When any Partner voluntarily withdraws from the General Partnership or dies, the General Partnership's business may continue without any settlement of accounts as between the voluntarily withdrawn or the heir of the deceased Partner; unless otherwise agreed in the Partnership Agreement. If the withdrawn or heir of the deceased Partner, or such Partner's legal 
representative have interest in the General Partnership at the date of dissolution, they shall receive, as ordinary creditors, an amount equal to the value of such withdrawn or deceased Partner's interest in the dissolved General Partnership with interest, or at their option in lieu of interest they can receive the profits attributable to the use of such withdrawn or deceased Partner's heir's right in the property of the dissolved General Partnership; provided that the creditors of the General Partnership, as against the creditors or the representative of the withdrawn or deceased Partner's heir, shall have priority on any claim arising under this ARTICLE.

ARTICLE 98. Incompetency of Partner:

If any Partner becomes incompetent, the provisions of ARTICLE 97 of this Law shall be applicable.

ARTICLE 99. Bankruptcy of Partners:

Unless otherwise stated in the Partnership Agreement, in case of the bankruptcy of one of the Partners, the bankrupt Partner is expelled from the General Partnership.

ARTICLE 100. Expulsion of a Partner by Court Decision:

If the request to dissolve a General Partnership is made by a Partner, the Court may, on request of the other Partners, make a decision to continue the General Partnership and expel the requesting Partner.

ARTICLE 101. Request of Dissolution of the Partnership or Refusal:

If a Partner requests the dissolution of a General Partnership whose business duration is unlimited one or more of [the other] Partners can reject the request for dissolution and continue with the General Partnership. In such a case, the matter concerning expulsion of the Partner shall be referred to the Court in accordance with the Provisions of this law.

ARTICLE 102. Request of Dissolution of the Partnership by one of the Partners:

If a Partner makes a request based on ARTICLE 94 to dissolve a General Partnership whose term of business is limited, the other Partner/Partners may pay out such requesting Partner's shares and continue the business of the General Partnership.

ARTICLE 103. Transferring the Debts and Assets:

If a General Partnership is composed of two Partners and one withdraws from the General Partnership, the remaining Partner may obtain a Court order transferring title to all the assets of the General Partnership's business without dissolution, or liquidation. In this case the provisions of ARTICLES 104 and 105 of this Law shall be applicable on the withdrawn Partner.

ARTICLE 104. Continuation of Administration and Transactions after Dissolution:

If there should be only two Partners in a General Partnership and if a person to whom a Partner is personally indebted should use such person's right to dissolve the General Partnership as set forth in ARTICLE 108, or if one of the Partners should go bankrupt, the other Partner may, in compliance with ARTICLE 102 of this Law, perform administrative affairs and execute the transactions of the General Partnership in such Partner's own account. 
ARTICLE 105. Payment of the Profit of the Partner who Withdraws from the Partnership: (1) Unless otherwise provided in the [Partnership] Agreement, the value of the General Partnership profit of a Partner who is expelled or who wishes to withdraw from a General Partnership is determined from the value of the assets of the General Partnership as of the date the expulsion demand has been made, and the sum shall be paid in cash.

(2) The profit of a Partner who is expelled or withdrawn according to paragraph (1) of this Article shall be paid at the time provided by the Partnership Agreement, however, if it is not determined in the Partnership Agreement the payment shall be made when the first balance sheet is prepared after the Partner is expelled or withdrawal.

ARTICLE 106. Expelled Partner and Non-involvement in the Decisions of the Partnership: A Partner who is expelled, or who has asked to withdraw, is to participate in the privileges and responsibilities of the transactions taking place before the expulsion is effective, but such Partner cannot prevent the execution of transactions already acted upon or decided by the other Partners. If the winding up of the General Partnership's business is not immediately possible, such expelled, or withdrawn Partner can ask at the end of the General Partnership's fiscal year for the accounts of transactions which have taken place during such fiscal year. Such expelled or withdrawn Partner also is entitled to request information on current transactions in progress at the end of the fiscal year.

ARTICLE 107. Payment of Personal Debt:

The expulsion or withdrawal of a Partner as it relates to third parties is in effect as of the date of registration and advertisement [of this matter], and prior to the date of such registration and advertisement, such partner shall continue to be responsible to third parties.

ARTICLE 108. Non-satisfaction of Debt:

If a person to whom a Partner is personally indebted should not be able to satisfy such person's claim from the personal properties of the debtor, such person may, at the time of the winding up of the General Partnership's business, control, through the order of the Court, the Partner's interest in the General Partnership, and may request [the Court] dissolve the General Partnership at the end of the fiscal year for any of the strong reasons provided in ARTICLE 100 of this law. The General Partnership, or the rest of the Partners, can, before the order to dissolve the General Partnership should become effective, pay the debt, or expel the debtor Partner, in accordance with ARTICLE 105 of this law. In such a case, the order of the Court shall be invalidated.

ARTICLE 109. Merger of Partnerships:

Two or more General Partnerships may merge or enter into any other type of amalgamation with each other to establish a new General Partnership. In this case the resulting new General Partnership shall be treated as a continuation of the prior General Partnership Companies and shall not be deemed to have been dissolved.

ARTICLE 110. Agreement of Partners for Merger:

For a merger of General Partnerships with agreement of all partners, separate decisions are to be made by each General Partnership and should be registered and advertised; unless otherwise provided by the Partnership Agreement. The merger shall be effective upon the later of Registration or advertisement. 
ARTICLE 111. Preparation of Balances of Merged Partnerships:

Each of the merged Partnerships must arrange and advertise its balance in unified forms. They must also approve decisions as to payment of debts and these decisions must accompany the balances. Each Partner may receive the balances and an explanation of them before the merger.

ARTICLE 112. Informing the Creditors about the Merger of the Partnership:

The decision to merge General Partnerships becomes effective three months after the date it has been registered and advertised. Each of the merged partnerships shall be obliged to give notice to known creditors of the merger. If the merged General Partnerships pay their debts, or deposit the equivalent amount in a recognized bank, or if the persons to whom they are indebted agree with the merger, it is not necessary to wait three months. The receipt received from the bank for the amount equivalent to debts is to be registered and advertised as well. Each of the persons to whom the merged General Partnerships are indebted can, within three months, submit a protest to the relevant Court on the matter of the merger. Until such time as the protester rescinds his protest, or the Court has made the final decision relating to the creditor who has protested, the merger cannot take place.

ARTICLE 113. Period of Time to Object to Merger:

If during the period mentioned in ARTICLE 112 of this law there should not be any protest, the merger becomes final. The newly created General Partnership is the successor of previous

General Partnerships and all the rights and responsibilities are transferred thereto. In this case the new partnership shall be registered and advertised.

ARTICLE 114. Liquidation of Deals:

If there are no provisions relating to the winding up of the business of the General Partnership in the General Partnership's Partnership Agreement, the winding up of the business of the General Partnership shall be executed in accordance with the provisions of this Law.

ARTICLE 115. Liquidation of Partnership:

The winding up of a General Partnership's business shall be the responsibility of the liquidating officers.

ARTICLE 116. Partnership's Liquidation Officers:

The liquidating officers shall be:

1. The persons determined as liquidating officers in the Partnership Agreement of the General Partnership;

2. If the liquidating officers are not determined in the Partnership Agreement, the persons elected as liquidating officers by the Partners either prior to, or after, the Partners' decision to dissolve the General Partnership; [or]

3. In the event that no liquidating officers are determined, each partner or his legal executor is deemed to be the liquidating officer for a General Partnership's business. Where a Partner petitions the relevant Court, the liquidating officers shall be assigned by the relevant Court.

ARTICLE 117. Appointment of Liquidation Officers: 
The liquidating officers, whether chosen by the Partners or assigned by the Court, may be among the Partners or persons other than partners.

ARTICLE 118. Decision of Liquidation:

If more than one liquidating officer shall be responsible for winding up the business of the General Partnership, such liquidating officers may work collectively and cooperatively in the winding up of the General Partnership's business. If one liquidating officer is to act independently on any given matter, he is obliged to register such matter with the Central Registry and inform third parties dealing with the General Partnership in the winding up of its business.

ARTICLE 119. Appointment of a Member of Partnership for Liquidation:

If a General Partnership transacts business while the General Partnership is winding up its business, the liquidating officers may elect only one person from among themselves to transact such business with third parties and such transaction is binding against the General Partnership if done for the purposes of winding up the General Partnership's business.

ARTICLE 120. Business Transactions of Partnership during Liquidation:

When a General Partnership's business is being wound up, on all contracts, or other documents, prepared in the name of the General Partnership the Statement "Winding up of the General Partnership" shall be recorded, and shall be signed by the General Partnership's liquidating officer, or officers. In the event that such Statement is not recorded on a contract, or other document, prepared in the name of the General Partnership while its business is being wound up the General Partnership the liquidating officer, or officers, shall be responsible to any third party with respect to such contract or other document, unless the third person has knowledge of the General Partnership's dissolution or winding up of its business.

ARTICLE 121. Preferential Rights:

The priority given to persons to whom the General Partnership is indebted over persons to whom Partners are personally indebted is protected even after the dissolution of the General Partnership.

ARTICLE 122. Insufficiency of Assets for Satisfaction of Debts during Liquidation: If the assets of the General Partnership at the time of dissolution are insufficient to satisfy the General Partnership's creditors, the Court may issue a decision that ca uses the bankruptcy of the Partnership in accordance with the provisions of the Law.

ARTICLE 123. Dismissal of the Liquidating Officer Pursuant to Agreement: If the liquidating officers of the General Partnership are elected according to the General Partnership's Partnership Agreement from among or outside of the Partners of the General Partnership before or after dissolution, such liquidating officers may be dismissed by the unanimous vote of the Partners. In the event that a unanimous decision [of the Partners to dismiss such liquidating officers] cannot be reached, the Court may order such removal, upon the request of any one of the Partners.

ARTICLE 124. Dismissal of Liquidating Officer by the Court:

A liquidating officer appointed by the Court may only be dismissed by the Court. 
ARTICLE 125. Request of Cooperation on Liquidation:

During the winding up of the General Partnership, the liquidating officers may:

1. Request that the managers of the General Partnership (if any) assist in the winding up of the General Partnership;

2. Prepare an accounting of the assets of the General Partnership and the General Partnership's current balance sheet if the managers do not assist;

3. If necessary, obtain an appraisal of the General Partnership's assets to determine their value. After the managers of the Partnership have signed the books and the prepared balance sheet, take control over, and responsibility for, the General Partnership's assets and accounts in the presence of such managers.

ARTICLE 126. Maintaining the Assets of the Partnership:

The liquidating officers shall be responsible for the safety of all assets and accounts of the General Partnership during the winding up of its business.

ARTICLE 127. Responsibilities of Liquidating Officer:

The liquidating officers are responsible for executing the following:

1. To complete all of the General Partnership transactions that commenced prior to its dissolution.

2. To pay the debts, and other claims, of the General Partnership in cash. If the persons to whom such debts are paid agree, such payment may be in kind.

3. To collect the General Partnership's third party claims and convert assets of the General Partnership into cash.

4. To take necessary actions to execute transactions necessary for the collection of the General Partnership's accounts, and for the distribution of General Partnership assets among the Partners.

ARTICLE 128. The Liquidating Officer as a Representative of the Legal Personality of the General Partnership:

The liquidating officers shall represent of the General Partnership's legal personality, while it is being wound up, before the Courts, or before other legal persons.

ARTICLE 129. Non-execution of Transactions not Related to the Liquidation of the Partnership: The liquidating officers cannot execute any transactions not related to the winding up of the business of the General Partnership. In the event that they do so, such liquidating officers shall assume any responsibility that might arise from such transactions.

ARTICLE 130. Resolution of Partnership's Transactions:

The liquidating officers are authorized to enter into negotiations, or (if necessary) to appoint an arbitrator, to resolve any transactions of the General Partnership.

ARTICLE 131. Sale of Properties of the Partnership:

The liquidating officers are permitted to sell the movable property of the General Partnership, whether at auction or by another way that provides maximum benefit for the Partnership, but the immovable property of the General Partnership, unless the Partners agree otherwise, may only be 
sold at auction. The presence of a minor or incompetent Partner shall not prevent the sale of the movable, or immovable, property of the General Partnership.

ARTICLE 132. Transacting Business not Related to Liquidation of the Partnership: The liquidating officers who are appointed by the Court, upon unanimous agreement of the Partners, may, if necessary, execute transactions that are unrelated to the winding up of the business of the General Partnership.

ARTICLE 133. Payment of Installment Debts:

The liquidating officers shall pay any installment debts of the General Partnership with discount as soon as possible where creditors agree.

ARTICLE 134. Payment of Debts:

If the assets of a General Partnership do not satisfy the liabilities of the General Partnership, the Partners shall be responsible for full payment of the liabilities of the General Partnership.

ARTICLE 135. Prohibited Sale of Partnership Properties:

Unless the Partners unanimously agree, the liquidating officers may not sell all of the General Partnership property in one lot.

ARTICLE 136. Increasing and Limiting the Powers:

The legal authority of the liquidating officers may be expanded, or limited, by the unanimous vote of the Partners, or by decision of the Court, if such expansion or limitation is registered with the Central Registry and advertised. If the matter of limitation or expansion of authority has not been registered and advertised such limitation or expansion does not affect third parties dealing in good faith with the General Partnership unless such third parties have knowledge of the facts regarding legal authority of the liquidating officers.

ARTICLE 137. Liquidation of the Partnership Limited to Decision of Partners or Court: During the winding up of the Partnership's business liquidating officers are bound by any decision made by the Partners or Court relating to the winding up of the Partnership's business. In case of bankruptcy, death, or incompetence of one of the Partners, ARTICLE 138 of this law shall be applicable.

ARTICLE 138. Appointments and Dismissals of Representative:

In case of bankruptcy, death, or incompetence of a Partner during the winding up of the General Partnership's business, the lawyer, or executor, of such Partner shall have the right to participate in Partnership decisions to appoint, dismiss, or give directions to any liquidating officers. The heirs [of such Partner] may also appoint a lawyer to represent such heirs. If the heirs fail to agree on appointment of a lawyer, or such Partner has no heirs, the Court may appoint a person as lawyer to represent such Partner's profits.

ARTICLE 139. Maintaining Some of the Properties of the Partnership for Payment of Debts: The liquidating officers may, after retaining the necessary reserves to satisfy debts of the General Partnership, distribute the remaining assets among the Partners. 
ARTICLE 140. Responsibilities of the Liquidating Officer:

The liquidating officers shall have the responsibilities as set forth below during winding up the business of a General Partnership;

1. Accurately prepare the final books and records of the General Partnership to secure proper winding up of the business of the partnership;

2. Report to the Partners orally, or in writing, regarding the status of the winding up of the business of the General Partnership upon request of the Partners;

3. Make available all books and records of the Partnership relating to the General Partnership's liquidation whenever the Partners so request. The liquidating officers may not prevent Partners from copying the General Partnership's books and records.

4. The liquidating officers, during the winding up of the business of the General Partnership, must deposit any money above the Partnership's operating requirements in a recognized bank.

ARTICLE 141. Recording and Advertising the Decisions of the Partners:

All statements in the General Partnership's Partnership Agreement relating to liquidating officers, together with directives decided upon by the Partners and the Court concerning the appointment, change, and dismissal of liquidating officers, is to be registered with the Central Registry and advertised.

ARTICLE 142. Responsibilities of Liquidating Officer after Termination of Liquidation: At such time that the winding up of the business of the General Partnership is complete the liquidation officers, according to the Partnership Agreement or to decisions made by the Partners or a Court, must prepare an accounting of the winding up and a balance sheet containing the shares of the Partners in the capital, profit, loss, and other items. The accounting and balance sheet must be submitted to the Partners. If the Partners raise no objection within one month, the accounting and balance sheet are considered final. After such one-month period, if Partners fail or refuse to accept such Partners' distributions of General Partnership assets, the liquidating officers may deposit such distributions under such Partners' names in a recognized bank.

ARTICLE 143. Distribution of Net Assets among the Partners:

The net assets of the General Partnership, in accordance with the Partnership Agreement or the decision of the Partners, should be distributed by the liquidating officers to the Partners, unless otherwise stated by the Partnership Agreement or as directed by the Partners, such distribution shall be made in cash.

ARTICLE 144. Liabilities of Liquidating Officers:

Liquidating officers are liable to the Partners and third parties for actions taken on their behalf by agents, or other representatives, who the liquidating officers appointed to perform their duties to the General Partnership.

ARTICLE 145. Wages of Liquidating Officers:

Liquidating officers appointed from among the Partners may not be compensated, unless so stated in the Partnership Agreement or upon the decision of other Partners. Liquidating officers who are not Partners, regardless of whether compensation has been stated in the Partnership Agreement or otherwise, are entitled to compensation for performing their duties as liquidating officers. 
ARTICLE 146. Depositing of Papers in a Safe Location:

At such time that the winding up of the General Partnership's business is complete, the General Partnership's books and records are to be deposited in a safe place designated by the Partners for a period of 15 years from the completion of the winding up of the business of the General Partnership. If the Partners do not agree regarding the place for such books and records to be kept, such place shall be assigned by the Court.

\section{CHAPTER 5:}

\section{SPECIAL PARTNERSHIPS}

ARTICLE 147. Application of Provisions of Chapter Four:

Unless otherwise stated in this law, rules of this law governing General Partnerships apply to Special Partnerships as well. Where it cannot be decided if a company is a General Partnership or a Special Partnership, it is considered to be a General Partnership.

ARTICLE 148. Registering the Name of Partners and the Capital Paid by Them: In the Special Partnership Agreement, in addition to the requirements of ARTICLE 152 of this law, the names of the Special Partners, as well as the capital of each that has been paid or promised, should be entered and should be, registered with The Central Registry, and advertised.

ARTICLE 149. Exception of Some Goods as Capital:

A Partner to a Special Partnership cannot submit such Partner's work, action, reputation, or profession (other than such Partner's scientific and technical invention or other intellectual [property] rights belonging to the Partner), as capital.

ARTICLE 150. Legal Relations of the General Partners:

The legal relations of General Partners to each other, to Special Partners, and to third parties are subject to provisions of CHAPTER 4 of this Law.

ARTICLE 151. Items Included in the Articles of Partnership:

A Special Partnership's Articles of Partnership, established on the basis of its Partnership Agreement shall include:

(1) The name of the Special Partnership;

(2) The address and name of its registered agent;

(3) The name(s) and address(es) of the Special Partnership's General Partner(s);

(4) The total number and value of the Special Partnership's authorized ownership shares, if any.

ARTICLE 152. Partnership Agreement in composition of the Articles of Partnership: The Partnership Agreement of Special Partnerships should be signed by all of the Partners. Partners who participate in the preparation of the Articles of Partnership are considered as founders. The founders cannot be fewer than five Partners provided that one of such founder is a Partner. Special Partners who are founders should include in the Partnership Agreement the amount they have agreed to contribute.

ARTICLE 153. Dismissal of Special Partnership Managers: 
Managers of Special Partnerships can be dismissed in accordance with the conditions and circumstances determined in ARTICLE 68 of this law.

ARTICLE 154. Involvement of General Partner in the Same Activity:

As in a General Partnership, a General Partner of the Special Partnership cannot engage in a company [Partnership] with a business identical to that of the Special Partnership without the permission of the rest of the General Partners of the Special Partnership or to subscribe in the company as a General Partner. The General Partner violating this is subject to the provisions of ARTICLE 78 of this law. However, if the other General Partners of the Special Partnership, or the Board of Supervisors, have notice of the participation by the General Partner in another company and do not object within one year after receiving notice, they shall be considered to have given permission.

ARTICLE 155. Appointment of Board of Supervisors:

The Special Partners may select a Board of Supervisors which may not include General Partners. The Board of Supervisors shall be responsible for carrying out the decisions made collectively by the Special Partners.

ARTICLE 156. Representation of Special Partners by Board of Supervisors:

The Board of Supervisors can represent the Special Partners in case of a claim between the General Partners and the Special Partners.

ARTICLE 157. Relationship among Partners:

Unless the Partnership Agreement provides otherwise, the relations among Partners is regulated by provisions of this law.

ARTICLE 158. Interference of Special Partners Prohibited into Administrative Affairs: Special Partners are not authorized to interfere into the administrative affairs of the Partnership and cannot prevent those authorized from executing their duties, but they can vote on transactions not included in the authority of the administrative personnel.

ARTICLE 159. Review and Investigation of Balance Sheet, Papers and Asset Books: Each Special Partner is allowed at the end of the year to investigate the balance sheet, asset books, and papers of the Special Partnership either personally, or through an informed person. If there is an objection to an opinion made by the informed persons, the informed person may be appointed by the Court on the request of the Special Partner.

ARTICLE 160. Establishment of an Institution whose Subject of Business Constitutes the Activities of Special Partnership:

The contents of ARTICLE 78 of this law are not applicable to Partners of the Special Partnership unless one or more of the Special Partners should establish an institution whose activities constitute the subject of the business of the Special Partnership, or join another person having established such an institution, or join an company doing the same business. Such Special Partners will not be entitled to investigate the books and papers of the Special Partnership.

ARTICLE 161. Responsibility Proportional to Capital: 
The responsibility of a Special Partner is limited to such Special Partner's promised or paid-in capital.

ARTICLE 162. Receiving of the Profit and Dividend by the Special Partner:

The Special Partner can at the end of the fiscal year receive such Special Partner's dividend, or if stated in the Special Partnership Agreement, such Special Partner's interest. If the Special Partnership has suffered a loss, until the loss is recovered, the interest is not paid but in future years, after the loss of capital is made up from remaining profit, the interest of previous years is paid out.

ARTICLE 163. No Return of Dividends:

(1) Special Partners are not required to return interest and dividends paid in previous years to make up for losses caused thereafter.

(2) Special Partners are not required to return dividends and interest received on the basis of a false or improperly prepared balance sheet.

ARTICLE 164. Legal Representative:

In case of the death of a Special Partner, such Special Partner's legal representative of the heirs replaces such Special Partner.

ARTICLE 165. Transferring Interest of Special Partner, Wholly, or in part, to Another Person: If a Special Partner transfers, without the permission of other Partners, such Special Partner's interest in the Special Partnership wholly, or in part, to another person, this new Partner is not entitled to investigate or interfere in, the affairs of the Special Partnership.

ARTICLE 166. Liability of Special Partner:

A Special Partner, whose name is in the title of the Special Partnership, has unlimited liability to third persons.

ARTICLE 167. Designation of Special Partner to Transact Business of the Partnership:

The responsibility to administer and represent a Special Partnership rests with the Partners who has unlimited liability. The extent of this authority is subject to the legislative documents that are applicable to General Partnerships. Unless otherwise stated in the Special Partnership Agreement, a Special Partner may be delegated, by the Manager, or Managers, of the Special Partnership, on the consent of such Special Partner, to execute certain transactions. In such cases the liability arising through the execution of such Special Partner's delegated transactions is that of the [Special] Partnership. If a Special Partner acts beyond such Special Partner's delegated duty, or acts without having been delegated, such Special Partner is personally liable for such Special Partner's actions.

ARTICLE 168. Consultation, Right to Investigation and Controlling the Affairs of the Partnership:

In compliance with the provisions of ARTICLE 159 of this law, the giving of advice and consultations, the right to investigate, and controlling the affairs of the Special Partnership and, participation in the appointment and dismissal of employees in accordance with law, or 
employment for minor work in the Special Partnership, cannot cause unlimited liability for the Special Partners.

ARTICLE 169. Liability of Special Partners to the Creditors of the Partnership:

The Special Partners are liable, until the time of dissolution of Partnership, to persons to whom the Special Partnership is indebted for the contributions they are obliged to make; or persons to whom the Special Partnership is indebted cannot, during the time that the case is under processing, refer to Special Partners. In the event of dissolution of the Partnership, the creditors have the right to claim against the entire assets of the Special Partnership.

ARTICLE 170. Prioritizing the Claims of Creditors:

In the case of dissolution of a Special Partnership, claims on the Special Partnership are given priority over claims on the Partners personally.

ARTICLE 171. The Equity of Rights of Personal Creditors and Partnership's:

In case the assets of a Special Partnership are not sufficient for the claims against it, creditors can demand their claims from the personal assets of the General Partners. In such cases the creditors of the Special Partnership and the creditors of the General Partners have equal rights.

ARTICLE 172. Demand for Committed Capital:

In case that the assets of the Special Partnership do not satisfy the debts incurred by the Partnership, the Partnership shall be authorized to demand the Special Partner's unpaid committed capital. In this case, the debts of a Special Partnership, as well as the debts of personal creditors, have equal status.

ARTICLE 173. Dissolution and Liquidation of Special Partnerships:

Provisions regarding the Liquidation of General Partnerships apply as well to Special Partnerships.

ARTICLE 174. Creditors of the Partnership:

Where a creditor of the Special Partnership is indebted to a [Special] Partner of such Partnership and the Special Partner has not fulfilled such Special Partner's promises to the Special Partnership, it is possible to apply the debt of the Special Partner against that of the creditor.

CHAPTER 6:

WORK PARTNERSHIPS

ARTICLE 175. Demand for Performance of Work and Demand for Wage by Partners: Each of the Partners in a Work Partnership shall be deemed a representative of the other Partners in accepting work on behalf of the Work Partnership and the owner of work may demand completion of work from any of the Partners. Conversely, each of the Partners may demand wages from the owner of work and if the owner of work pays the wages for such work to one of the Partners, such payment shall be deemed payment of the wages to all of the Partners.

ARTICLE 176. Delegation of Work to Others: 
Unless otherwise provided in the Work Partnership Agreement, a Work Partner may assign such Partner's work to another Work Partner, or to other persons, unless the owner of work has stated to the Partners that the work must be completed by a specific Work Partner.

ARTICLE 177. Distribution of Profits for the Work Performed:

Profits shall be distributed among the Work Partners as is agreed upon [by the Partners]. In determining the distribution of profits among the Work Partners, the amount of work performed by each Work Partner may be made a condition to the amount of wages paid to each such Partner.

ARTICLE 178. Ensuring Wages of Work:

A Work Partner shall be entitled to a portion of the profits by guaranteeing the performance of the work even though such Partner did not perform the work.

ARTICLE 179. Compensation of Damages Regarding the Work:

Where the work is damaged by one or more of the Work Partners, the owner of work can compel one or more of the Work Partners to compensate the owner of the work for such damages. The loss shall be borne by the Work Partners in accordance with the terms of the Work Partnership Agreement. In the event that there is no Work Partnership Agreement, then the loss shall be borne by the Work Partners in proportion to their share of the profits of the Work Partnership; if the loss is caused by an act of gross negligence of one, or more, of the Work Partners, then the loss shall be borne by the Partners who acted with gross negligence.

ARTICLE 180. Provision of Work Site and Equipment:

In a Work Partnership, some of the Work Partners may provide the work site and other Partners may supply certain work equipment and performance of the work.

\section{CHAPTER 7:}

\section{MISCELLANEOUS PROVISIONS}

ARTICLE 181. Continuation of Business:

(1) Any partnership which has obtained a business license from the authorized State Authorities, before the effective date of this Law, and which has registered such license at the Administration for Documents and Trademarks, shall there after continue its legal existence and be governed under the provisions of this Law. Partnership(s) which are not constituted in compliance with this Law shall not be legal Partnership(s).

ARTICLE 182. Paying Tax Duties:

The Partnerships referred to in this law and their Partners shall be responsible to pay all taxes and any other charges due, in accordance with the provisions of this law.

ARTICLE 183. Enacting Rules, Regulations and Procedures:

For the better implementation of this law, the Ministry of Commerce and Industry propose Regulations and enact relevant Procedures and Rules.

ARTICLE 184. Effective Date: 
This Law is applicable from the date of signing [by the President] and shall be published in the Official Gazette. As of the Effective Date, the provisions of Articles relating to Partnerships in the Commercial Code published in the Official Gazette \#89, dated Mizan, 1336 and Civil Code dated 15.10 .1355 and any other provisions of other laws which contradict the provisions of this law, are voided. 


\title{
THE CORPORATIONS AND LIMITED LIABILITY COMPANIES LAW OF AFGHANISTAN
}

In the Name of Allah, the compassionate, the merciful

\author{
CHAPTER 1 \\ GENERAL PROVISIONS
}

ARTICLE 01: Purpose

This Law is enacted in light of the Constitution of Afghanistan for regulating the affairs related to the creation and activities of corporations and limited liability companies.

ARTICLE 02: Having License

No person can transact business or advertise as a corporation and limited liability company in Afghanistan without having a business license registered in the Central Registry.

ARTICLE 03: Scope of Application

The provisions of this Law shall apply to a limited liability company, provided that:

1. The shareholders of the limited liability company are neither less than 2 nor more than 50 persons.

2. Shares of the limited liability company are not purchase $d$ or sold in a public stock exchange.

3. The shareholders of the limited liability company are not authorized to sell, transfer or exchange the company.

ARTICLE 04: Definitions

In this Law the following terms shall have the meanings set forth below:

1. "Corporation" is a business company whose capital is definite and divided into shares, with the share and responsibility of each shareholder limited to the proportion of his share.

2. "Limited Liability company"; "Limited" is a business company whose capital is not divided into shares with the responsibility of each shareholder limited to the amount of capital agreed to [by such shareholder] in the company.

3. "Articles of Incorporation": means any document prepared by the founders or shareholders according to provisions of this Law for the purpose of legitimizing their activities. Articles of Incorporation shall include:

(1) The original charter;

(2) All amendments to such charter; [and]

(3) Certificates of merger of two or more companies.

When the Articles of Incorporation have been restated pursuant to any Articles of Amendment or Merger, it does not include the accompanying Articles of Amendment or Merger.

4. "Authorized Shares" means the Shares that any Domestic or Foreign Corporation is authorized to issue.

5. "Share" means the unit into which the capital of a Corporation is divided.

6. "Shareholder" means the Person in whose name Shares are registered in the Central Registry of Shares of the Corporation, and is the beneficial owner of Shares to the extent of the rights granted in a registered bidding document filed in the Central Registry of the Corporation, or the 
beneficial owner of Shares, who assigns his voting rights to a third party [owner of shares held in a Voting Trust].

7. "Share Class" means a group of similar shares which confer the same rights on the holders of such shares [the shareholders].

8. "Dividend" means a part of the company's net earnings that are distributed to Shareholders in accordance with the rights determined for each kind and class of shares.

9. "Redeemable Share" means a Share that may be redeemed at the option of the Shareholder.

10. "Capital Stock" means the total par value (face value) of all shares offered by the company.

11. "Reserved Capital" means the total capital collected for each single share of the company

from the beginning to the end. [sec]

12. "Certification" means the verification of the Central Registry concerning effectiveness of the Articles of Incorporation, which is issued upon registering it at the Central Registry.

13. "Derivative Action" means any civil proceeding by a Shareholder on behalf of the interests of the Corporation.

14. "Central Registry" means the agency for registering the documents related to domestic and Foreign Corporations.

15. "Commercial Court" means the authorized Commercial Court of Afghanistan.

16. "Domestic Corporation" means for the purpose of this Law a Corporation that: is authorized by law to issue shares, irrespective of the nature of [its] business, is organized under this Law or existing pursuant to the previous laws of Afghanistan, by virtue of Articles of Incorporation, Amendment, or merger, has become a domestic Corporation. A foreign Corporation organized under laws of foreign companies that operate in Afghanistan shall be subject to the provisions of this Law.

17. "Electronic Transmission" means any form of communication, not directly involving the physical transmission of paper that creates a historical record that may be retained, retrieved and reviewed by a recipient thereof, and that may be directly reproduced in paper form by such a recipient.

18. "Right of Pre-emption" means the right of Shareholders to maintain their stock ownership through purchase of additional Shares and securities that may be converted to issues of Shares, prior to any offer of them to third parties.

19. "Right of Preference" means the right devoted by the Articles of Incorporation to a group of Shares which provide the Shareholders with the same rights.

20. "Voting Trust" means transferring to or conferring on a trustee the right to vote.

21. "Employee" means an officer or person employed by a Corporation or its affiliated entities to perform duties related to the company. A Director may simultaneously perform duty as an officer.

22. "Entity" can be a

_ Natural domestic person - which is a person having Afghan citizenship;

- Domestic legal person - which is an organization, company, proprietary ownership, limited

liability company, temporary partnership, temporary investment company, association, or any other for-profit organization, which is established according to the provisions of law;

Foreign natural person - which is a person that has non-Afghan citizenship;

Foreign legal person - which is a person whose legal existence is defined under non-Afghan laws.

23. "Head Office" means the office, in or out of Afghanistan, where the principal executive

offices of a Domestic or Foreign Corporation are located, or, if there are no such offices, the 
office, in or out of Afghanistan, so designated by the Board of Directors. The designation of the principal office in the most recent Annual Report shall be regarded as the Head Office for the purposes of this Law.

\section{CHAPTER 2}

\section{REGISTRATION REQUIREMENTS FOR CORPORATIONS}

ARTICLE 05: Registration of Documents:

(1) The following documents may be registered in the Central Registry office:

1. The written documents which contain the information specified by this law;

2. The documents typewritten or printed in black;

3. Documents that may be copied;

4. Documents that are legible;

5. Document prepared in one of the official languages (Pashto or Dari).

(2) The Articles of Incorporation of Foreign companies may be in a foreign language, provided that it is accompanied by an accurate Dari or Pashto translation.

ARTICLE 06: Preparation of Documents:

The document of a Corporation shall be prepared by the following persons:

1. By Officer(s) authorized to execute action on behalf of the Corporation;

2. The Board of Directors of the Corporation;

3. One or more incorporators of the Corporation;

4. The receiver, Trustee, or other Court-appointed fiduciary.

ARTICLE 07: Preparation of the Annual Report:

Annual reports shall be prepared by an officer or Director of the company and shall be registered in accordance with this Law.

ARTICLE 08: Certification of the Seal and Signature:

The Person executing the document shall sign it and state beneath or opposite his signature his name and the capacity in which he signs. Any signature may be a facsimile. The signature and corporate seal shall be attested and verified by the secretary or an assistant secretary.

ARTICLE 09: Preparation of special forms:

If required pursuant to any provision of this Law, the Central Registry may prepare a document in a special form.

ARTICLE 10: Payment of the Fee:

The document delivered to the Central Registry for registration shall be registered when the applicable filing fee is paid in accordance with this law.

ARTICLE 11: Electronic Registration:

The Central Registry may accept the electronic registration of any information permitted by this Law and may prescribe the methods of execution, recording, reproduction and certification of electronically filed information. 
ARTICLE 12: Correcting Articles of Incorporation:

(1) The Board of Directors of a Corporation may authorize correction of any Articles of Incorporation filed with the Central Registry;

(2) Correction of Articles of Incorporation referenced in paragraph (1) of this Article may be made when: (i) it contains an incorrect statement; (ii) it is defectively executed, verified, certified, signed or sealed.

(3) Upon the issuance of a Certificate of Correction mentioned in paragraph (2) of this Article, the Articles of Correction shall be filed together with the effective date of the correction.

(4) No Articles of Correction shall be accepted by the Central Registry when received more than ten days after the effective date of the Certificate relating to the Articles of Incorporation to be corrected.

CHAPTER THREE

ISSUANCE OF REGISTRATION CERTIFICATE

ARTICLE 13: Issuance of Certificate:

The Central Registry can only issue a certificate if the document has been prepared and registered according to the provisions of this law.

ARTICLE 14: Certificate of Existence:

(1) Anyone may apply to the Central Registry to furnish a Certificate of Existence for a

Domestic or Foreign Corporation. The Certificate may state any other facts of record with the Central Registry that are requested by the applicant.

(2) The Certificate of Existence of the Corporation includes the following:

1. Activity of the Corporation in Afghanistan;

2. That the Corporation has not dissolved or ha s not terminated its activities;

3. The name of the Domestic or Foreign Corporation as it is registered in Afghanistan;

4. The date of the establishment of the Corporation and the period of its duration if for a limited period;

5. That the Foreign Corporation is authorized to transact business in Afghanistan;

6. The date of registration of the Articles of Incorporation in the Central Registry.

ARTICLE 15: Requirement of the Existence of the Corporation:

(1) Foreign or Domestic Corporations in Afghanistan shall be deemed to be in existence under the following terms:

1. Having a business license;

2. Payment of all fees, fines, penalties and interest in accordance with the provisions of this Law;

3. Filing annual reports with the Central Registry in accordance with this law;

4. No dissolution or withdrawal of activities.

5. If the Corporation does not meet the above-mentioned requirements, the Central Registry shall certify the dissolution or termination of the activities of the Corporation.

6. A Certificate of Existence issued by the Central Registry shall be regarded as conclusive evidence that the Domestic or Foreign Corporation is in existence as a Corporation.

\section{CHAPTER FOUR}




\section{PAYMENT OF FEES}

ARTICLE 16: Fees to be Collected:

The Central Registry shall collect the registration fees imposed by this law and transfer the money to the income account of the State and assure the relevant authority that this money is paid.

ARTICLE 17: Effective Date of the Certificate:

1. A Certificate issued by the Central Registry is effective at the time such Certificate is issued unless the Articles of Incorporation provide otherwise.

2. Any other document filed with the Central Registry shall be effective when accepted and filed by the Central Registry unless otherwise provided for in this Law.

3. Any Certificate that has a delayed effective date shall be deemed to be effective when the Certificate is issued.

4. When a Certificate has a delayed effective date and the parties which filed this Certificate request a cancellation, and the Central Registry registers that, such Certificate shall become void.

\section{CHAPTER FIVE \\ PROCEDURES FOR ESTABLISHMENT OF A CORPORATION}

ARTICLE 18: Establishment of a Corporation:

A Domestic Corporation is established for any lawful business in accordance with this law and the relevant Articles of Incorporation, whose capital is definite and divided into Shares, with the responsibility of each Shareholder limited to the value of his or her Share.

ARTICLE 19: Activities of the Corporation:

Unless its Articles of Incorporation provide otherwise, every Corporation has perpetual duration and has the same powers as an independent Entity which operates legally to execute business transactions and other affairs.

ARTICLE 20: Incorporators:

One or more Person s may act as the Incorporator by signing and filing Articles of Incorporation with the Central Registry

ARTICLE 21: Articles of Incorporation:

(1) The Articles of Incorporation must include the following:

1. The name of the Corporation;

2. The name and address of each Incorporator and Director;

3. The address of its Registered Office in Afghanistan and the name of its responsible agent at such office;

4. The number and types of Shares the Corporation is authorized to issue;

5. The duration of the Corporation, which duration will be assumed to be infinite unless otherwise limited in the Articles of Incorporation.

(2) The Articles of Incorporation may include the following, as well as terms mentioned in Article 20(1) above:

1. Any provision defining or denying the priority right of Shareholders to acquire unissued Shares of the Corporation; 
2. The purpose for which the Corporation was organized;

3. Par value for Capital Stock;

4. Limiting the liability of Directors;

5. Any provision otherwise required which is not against the provisions of this law.

ARTICLE 22: Signing the Articles of Incorporation:

(1) Corporate existence begins when the Articles of Incorporation are signed by the Incorporators or a person to whom the power to sign has been delegated by agreement, and the Articles have been registered with the Central Registry.

(2) Notice of the formation of a Corporation, including the name and registered address of the Corporation, shall be advertised in accordance with the law.

ARTICLE 23: Pre-Incorporation Activities:

All Persons purporting to act on behalf of a Corporation prior to its establishment shall be liable for all liabilities created while so acting, except for any liability to any Person who knew that there was no Corporation formed under this Law.

ARTICLE 24: Activities of the Board of Directors:

(1) The Board of Directors can start their activities after establishment of the Corporation and can hold their meeting $\mathrm{s}$ inside or outside Afghanistan according to the provision of this law.

(2) According to the provisions of this law, incorporators of the Corporation can hold their meetings inside or outside Afghanistan.

(3) According to the provisions of this law, the incorporators of a Corporation can make decisions without holding meetings if the action taken is evidenced by a written consent signed by each incorporator.

\section{CHAPTER SIX} BY-LAWS

ARTICLE 25: Enacting By-Laws

The incorporators or Board of Directors, of a Corporation may adopt by-laws to better implement the relevant Articles of Incorporation, provided that it is not inconsistent with this law or the Articles of Incorporation.

ARTICLE 26: Corporate Name:

A corporate name shall contain the word "corporation", "incorporated", "company", or "limited", or the abbreviation "Corp.", "Inc.", "Co.", or "Ltd."

ARTICLE 27: Prohibited Corporate Names:

The Incorporators cannot select the following names for their corporation:

1. A corporate name that is prohibited by law for a Corporation;

2. A name that has been selected and registered with the Central Registry for another Corporation;

3. A name of a Foreign Corporation, unless the selected name can be distinguished from the foreign name. 
ARTICLE 28: Maintaining a Business Office:

Each Corporation in Afghanistan shall:

1. Have a business office that has been registered with the Central Registry.

2. Have a responsible agent at the location of the registered office. The registered agent may be an individual Person or a Domestic Corporation.

ARTICLE 29: Obligations of the Agent:

1. The duty of the registered agent is to receive service of any process, notice or demand on behalf of the Corporation that is required or permitted by law to be served on the Corporation, and to forward the goods provided through him to the Corporation at its last known address.

2. Whenever a claim is made against a Corporation and its registered agent can not be found at the registered office, then the responsible person shall be found and searched on the basis of the Central Registry.

\section{CHAPTER SEVEN ISSUANCE OF SHARES}

ARTICLE 30: Issuance of shares for consideration:

A Corporation may issue its Shares of Capital Stock when authorized by the Board of Directors for consideration, consisting of any tangible or intangible property, or benefit to the Corporation, including cash, commitment for services that have been performed or contracts for services to be performed.

ARTICLE 31: Receiving consideration for shares:

If the Board of Directors determines, in good faith, that the consideration received, or to be received, for the Shares to be issued is adequate, such determination is conclusive and final regarding the adequacy of consideration as far as the Shares are validly issued and fully paid. When the Corporation has received the payment for the Shares, the Shares issued therefore are fully paid.

ARTICLE 32: Offer of Shares:

Shareholders of a Corporation wishing to issue their Shares to the public may do so in accordance with rules established by the Central Registry or other competent authorities.

\section{CHAPTER EIGHT \\ BOARD OF DIRECTORS}

ARTICLE 33: Board of Directors of a Corporation:

(1) The Corporation shall have a Board of Directors, which according to the Articles of Incorporation, By-Laws, and agreements of the Shareholders is an authorized Board to direct and regulate the affairs of the Corporation.

(2) The Board of Directors shall have the power to represent the Corporation and execute any legal document subject to any limitations set forth in the Articles of Incorporation.

ARTICLE 34: Selection Requirements for members of the Board of Directors: 
(1) A person may only be selected as a member of a Board of Directors with the following qualifications:

1. Natural persons who are eighteen (18) years of age;

2. Persons that have never been deprived of civil rights by a court order;

(2) The Board of Directors may be composed of one or more members. The minimum and maximum number of members and other relevant conditions shall be stipulated in the Articles of Incorporation or the By-Laws of the company.

ARTICLE 35: Appointment of the members of the Board of Directors:

(1) Directors shall be elected by the Shareholders at each Regular/Annual Shareholder's Meeting, in accordance with the Articles of Incorporation.

(2) The Articles of Incorporation, or By-laws, may authorize the Shareholders, or the Board of Directors, to fix or change the number of Directors.

ARTICLE 36: Term of Directors:

(1) The terms of the Initial Directors of a Corporation expire at the first Shareholders' Meeting at which Directors are elected.

(2) The terms of Directors shall be for the length determined by the Shareholders, not to exceed three years.

(3) A Director elected to fill a vacancy on the Board of Directors shall serve for the unexpired term of his predecessor in office.

(4) If there shall be an increase in the number of Directors, the new members of the Board shall be elected, but only for a term of office continuing until the next election of Directors.

(5) Despite the expiration of a Director's term, he continues to serve until his successor is elected and qualifies, or until there is a decrease in the number of Directors.

ARTICLE 37: Resignation of a Director:

A Director may resign at any time by delivering written notice to the Board of Directors, its Chairman, or to the Corporation. A resignation is effective on the date of notice.

ARTICLE 38: Dismissal of a Member of the Board of Directors:

(1) The Shareholders, by majority vote, may remove one or more Directors, with or without cause, unless the Articles of Incorporation, or By-laws, provide otherwise.

(2) One or more Directors may be removed by the Shareholders at a Special Meeting called for the purpose of removing him, which includes the matter in the agenda.

ARTICLE 39: Election of a Chairman:

Each year the Members of the Board of Directors shall elect from among themselves, a Chairman of the Board, unless required otherwise by the Articles of Incorporation, or the Bylaws.

ARTICLE 40: Vacancy on the Board:

(1) Unless the Articles of Incorporation, or By-laws, provide otherwise, if a vacancy occurs on a Board of Directors, including a vacancy resulting from an increase in the number of Directors, the Board of Directors may fill the vacancies, the term of which shall be the unexpired term of such vacant position. 
(2) A vacancy that will occur at a specific later date (by reason of a resignation effective at a later date or otherwise) may be filled by the Board of Directors before the vacancy occurs, but the new Director may not take office until the vacancy occurs.

ARTICLE 41: Power of the Board of Directors:

Subject to the limitations within the Articles of Incorporation, the Board of Directors is entitled to execute and sign any legal document and to represent the Corporation in legal transactions.

ARTICLE 42: Holding Meetings:

(1) The Board of Directors may hold Regular/Annual or Special Meetings in any location.

(2) Unless the Articles of Incorporation, or By-laws, provide otherwise, the Board of Directors may permit any, or all, the Directors to participate in a Regular/Annual or Special Meeting by any means of communication by which all Directors participating may simultaneously hear each other during the meeting, including through the use of telephone or video conference. A Director participating in a meeting by this means is deemed to be present in person at the meeting.

ARTICLE 43: Actions without Holding a Meeting:

(1) Unless the Articles of Incorporation, or By-laws, provide otherwise, action required to be taken at a Board of Director's meeting shall be valid when taken without a meeting if the action is taken in writing by all members of the Board.

(2) The action of the Board of Directors mentioned in paragraph (1) of this Article and the minutes of the meeting shall be filed with the Corporation records. Such action shall be regarded as voting in the meetings of the Board. The action has the effect of a vote at a meeting of the Board of Directors.

ARTICLE 44: Notice of Meeting:

(1) Unless the Articles of Incorporation, or By-laws, provide otherwise, notice of the date, time and place of Regular/Annual or Special Meeting(s) of the Board of Directors shall be given to members of the Board of Directors no fewer than two days prior to such meeting.

(2) A Director may waive any notice required by paragraph (1) of this Article, in compliance with the Articles of Incorporation, or By-laws, before, or after, the date and time stated in the notice. The waiver must be in writing, signed by the Director entitled to the notice, and filed with the corporate records.

(3) A Director's attendance at, or participation in a meeting acts as a waiver of any required notice to him, unless the Director at the beginning of the meeting (or promptly upon his arrival) objects to holding the meeting and does not thereafter vote on any proposal at the meeting.

ARTICLE 45: Quorum and Decisions by Meetings:

(1) A quorum of the meeting is complete by a majority of the number of Directors.

(2) Decisions are taken in Board of Director's meetings by a majority of the variable number of Directors, unless the Articles of Incorporation and By-laws provide otherwise.

ARTICLE 46: Committees:

(1) Unless the Articles of Incorporation or By-laws does not provide so, a Board of Directors may create one or more committees to perform the relevant affairs and appoint members of the Board of Directors to serve on them, and may delegate authority to such committees to act on 
behalf of the Board of Directors. Each committee may have one or more members, who serve for the period determined by the Board of Directors.

(2) The provisions of this Law that govern the Board of Directors, also apply to committees and their members.

(3) A Committee may not:

1. Perform the functions and exercise powers related to shareholders;

2. Appoint any person to fill a vacancy on the Board of Directors, or on any committee;

3. Propose the amendment or adoption of Articles of Incorporation, or By-laws;

4. Approve a plan of merger or dissolution of the Corporation.

ARTICLE 47: Responsibility of Directors:

(1) A Director shall have the following duties:

1. To ensure the best interest of the Corporation and its Shareholders;

2. To discharge assigned duties with due diligence.

(2) In discharging his duties mentioned in paragraph (1) of this Article, a Director is entitled to rely on information, opinions, reports, or statements, including financial statements, and other financial data, when he wants to make sure that they are prepared and presented by:

1. One or more officers or employees of the Corporation whom are reliable;

2. Legal counsel, accountants, bankers, or other persons who are professional and with expert competence;

3. A committee which merits confidence, even if not included in the Board of Directors.

(3) In instances described in paragraph (2) of this Article, a Director is not entitled to rely on information which is not true or persons that makes reliance unwarranted.

(4) If the member of the Board of Directors does not perform his duties in good faith and according to paragraphs (1) and (2) of this Article, he/she is responsible to the Corporation and the shareholders.

ARTICLE 48: Derivative Actions:

(1) A Derivative Proceeding may be brought by a Shareholder in the right of a Corporation against one or more of its Directors, or Officers, in the event of the failure to perform, or other violation of their duties in management of the Corporation.

(2) A Shareholder may not commence a Derivative Proceeding unless he was a Shareholder at the time of the act or omission that is the subject of his complaint, and he fairly represents the interests of the Corporation. Derivative Proceedings may not be commenced more than four years from the time the cause of action occurred.

(3) Prior to commencing a Derivative Proceeding, a Shareholder must first make written demand on the Corporation requesting that it take suitable action. The Corporation shall respond within 90 days following such a request by either commencing the requested action or by rejecting the request, provided that it may be commenced prior to the date that material harm to the Corporation would likely result.

(4) This ARTICLE 48 shall not limit any liability otherwise imposed by law upon any Director or Officer, or any third party.

ARTICLE 49: Unlawful Distributions of Corporate Assets:

(1) Directors who engage in distribution of the Corporation's assets in violation of ARTICLE 99, or the Articles of Incorporation, are personally liable. Directors held liable hereunder shall 
demand reimbursement from each Shareholder for the amount the Shareholder accepted, if such Shareholder knew the distribution was unlawful.

(2) A Shareholder that has incurred a loss due to the illegal distribution mentioned in paragraph

(1) of this Article may file a claim within two years.

ARTICLE 50: Conflict of Interest in Transactions:

(1) If a member of the Board of Directors has a conflict of interest in a business transaction, he must disclose the matter to the Board of Directors of the Corporation. Otherwise he will be responsible.

(2) "Conflicting Interest" with respect to a Corporation means: the interest of a Director of the Corporation in a transaction effected, or proposed to be effected by the Corporation (or by a subsidiary of the Corporation), where the Director at the time of commitment, or his related person, is a party to the transaction or has beneficial financial interest in the transaction, that exerts a financial influence on the Director or his related person.

(3) "Director's Conflicting Interest Transaction" with respect to a Corporation means: a trans action effected, or proposed to be effected, by the Corporation (or by a subsidiary of the Corporation, or any other Entity in which the Corporation has a controlling interest) respecting which a Director of the Corporation has a Conflicting Interest.

(4) "Related person" of a Director means the spouse, parent, brother, sister, child, grandchild, sibling (or spouse of any thereof) of a Director, or an individual having the same home as the Director, or a trust, estate, incompetent, conservatee or minor of which the Director is a fiduciary.

(5) "Disclosure" according to paragraph (1) if this Article means: disclosure by the Director who has a Conflicting Interest where the existence and nature of the disclosure relates to him, and disclosure of all the facts that the Director has already known concerning the subject matter.

ARTICLE 51: Judicial Action:

(1) A transaction shall be effected, or proposed to be effected, by a Corporation (or by a subsidiary of the Corporation or by any other controlled Entity) when it is not a Director's Conflicting Interest Transaction as defined in Article 50 of this law, is not prohibited or enjoined by the court in an action by a Shareholder, or a Derivative Proceeding based on such Director's interest in the transaction, and is not sentenced to payment of damages or to other limitations. [Sec]

(2) A Director's Conflicting Interest Trans action may not be enjoined by the court or set aside, or give rise to an award of damages, or other sanctions in an action by a Shareholder or a Derivative Proceeding unless:

1. Shareholders' approval relating to the transaction was, at any time, taken in compliance with ARTICLE 53;

2. The transaction, judged in the circumstances at the time of commitment, is established to have been fair to the Corporation.

ARTICLE 52: Directors' Approval:

(1) Directors' approval regarding a transaction is effective if the transaction received the affirmative vote of a majority of the Qualified Directors or after required disclosure in compliance with this ARTICLE. 
(2) If a Director has a Conflicting Interest respecting a transaction, but neither he nor a $r$ elated Person is a party thereto, and if the Director has a duty under law, or a duty of confidentiality to another person regarding information relating to the transaction such that the Director cannot, consistent with that duty, make the required disclosure, then disclosure is sufficient for these purposes if the Director:

1. Discloses to the Directors voting on the transaction the existence and nature of his Conflicting Interest and informs them of the character of, and limitations imposed, by that duty, prior to their vote on the transaction; and

2. Does not, directly or indirectly, participate in the discussion, vote.

(3) Qualified Directors who constitute a quorum hereunder, have no conflict of interest in the transaction and neither have a familial, financial, professional or employment relationship with another Director who does have a conflict of interest.

ARTICLE 53: Shareholders' Approval:

(1) Shareholders' approval regarding a transaction is effective for purposes of Article 51(2) 2, if approved by a majority vote of all Qualified Shareholders after disclosure.

(2) Qualified Shares means any Shares the holders of which are entitled to vote with respect to a Director's Conflicting Interest Transaction, except Shares owned by a Director (or a Related Person) with a Conflicting Interest in such transaction.

ARTICLE 54: Preparation and Delivery of Financial Statements:

(1) Not less than 15 days prior to the Regular/Annual Meeting of the Shareholders, the Corporation shall deliver to all of the Shareholders entitled to attend such Meeting Financial Statements dated as of the last day of the fiscal year of the Corporation, which shall include the balance sheet dated as of the last day of the fiscal year and the profit and loss statement of the Corporation for the fiscal year. All Financial Statements shall include all operations of the company and shall comply in all material respects, with the applicable accounting standards set forth by the International Accounting Standards Board.

(2) The Financial Statements, as well as the Corporation's books and records, shall be made available to all Shareholders for investigation at the Corporation's main office not less than 15 days prior to the Regular/Annual Meeting of the Shareholders.

ARTICLE 55: Rights and Privileges:

Unless the Articles of Incorporation or By-laws provide otherwise, the Board of Directors may set the compensation of Directors, subject to approval by the Shareholders.

ARTICLE 56: Maintaining Corporate Records:

The Board of Directors, in addition to keeping required commercial books, must also keep the following records:

1. A Shareholders' registry in which the name, address and number of owned Shares of each Shareholder are recorded;

2. A record of initial payments made for capital and the increase s therein;

3. A record of the minutes of meetings of the Shareholders and the Board of Directors;

4. The Financial Statements, as presented annually to the Shareholders.

ARTICLE 57: Appointment of Officers: 
(1) Unless otherwise provided in the Articles of Incorporation, or By-laws, the Board of Directors may appoint officers of the Corporation.

(2) The Officers shall have the grades, terms, duties and responsibilities as determined, from time to time, by the Board of Directors.

(3) Officers who are not Shareholders may simultaneously hold more than one office, and may also be a $\mathrm{m}$ ember of the Board of Directors.

ARTICLE 58: Indemnification:

(1) Any person who is a party to any action or suit, whether civil, criminal, administrative or investigative (other than a Derivative Proceeding) by reason of the fact that the person is, or was a Director, officer, employee or agent of the Corporation, shall be indemnified by the Corporation against expenses (including attorneys' fees), judgments, fines and amounts paid in settlement that are actually and reasonably incurred by such person in connection with such action, suit, or Proceeding if the person acted in good faith, and in a manner which is in the best interests of the Corporation, and, with respect to any criminal action or Proceeding, had no reasonable cause to believe the person's conduct was unlawful.

(2) A Corporation shall have power to indemnify any person who is, was, or is threatened to be made a party to any Derivative Proceeding, or suit by, or in the right of, the Corporation by reason of the fact that the person is, or was a Director, officer, employee, or agent of the Corporation, against expenses (including attorneys' fees) incurred by such person in connection with the defense, or settlement of such action, or suit, if the person acted in good faith and in a manner which is in the best interests of the Corporation, shall be an exception to this rule [sec]. (3) To the extent that a present, or former Director, or officer of a Corporation has been defending in an action, suit, or proceeding referred to in this ARTICLE, such person shall be indemnified against expenses (including attorneys' fees) incurred by such person.

(4) Expenses (including attorneys' fees) incurred by an officer or Director in defending any civil, criminal, administrative, or investigative action, suit, or proceeding may be paid by the Corporation prior to the final disposition of such action, suit, or proceeding, upon receipt of an undertaking by, or on behalf of, such Director or officer to repay such amount if it shall ultimately be determined that such person is not entitled to be Indemnified by the Corporation as authorized in this ARTICLE 57. Such expenses (including attorneys' fees) incurred by such person (s) may be so paid upon such terms and conditions, if any, as the Corporation deems appropriate.

(5) The Indemnification and advancement of expenses pursuant to this ARTICLE shall not be deemed exclusive of any other rights to which those seeking Indemnification, or advancement of expenses, may be entitled under any charter, Agreement, vote of Shareholders, or disinterested Directors, or otherwise. A Corporation may purchase insurance on behalf of any Director, officer; employee, or agent of the Corporation against any liability asserted against, or incurred by, such person those acting in capacities.

(6) The advancement of expenses provided by this ARTICLE shall, unless otherwise provided when authorized, continue as to a person who has ceased to be a Director, officer, employee, or agent and shall inure to the benefit of the heirs, executors and administrators of such person.

CHAPTER NINE

BOARD OF SUPERVISORS 
ARTICLE 59: Electing the Board of Supervisors:

(1) The Board of Supervisors of the Corporation shall be composed of two or more members, that shall be elected by the Shareholders at the Regular/Annual Meeting of Shareholders, unless provided otherwise in Articles of Incorporation or the By-laws. If appointed in the Articles of Incorporation, the first term shall be for one year, and thereafter for a maximum period of three years. The Board of Supervisors whose term has expired may be re-elected.

(2) Members of the Board of Supervisors cannot also be members of the Board of Directors nor can they administer the business operations of the Corporation.

ARTICLE 60: Dismissal:

Members of the Board of Supervisors can, at any time, be dismissed by the Shareholders. A member who is a Shareholder cannot ask for damages or other compensation related to his dismissal.

ARTICLE 61: Vacancies on the Board of Supervisors:

If a member of the Board of Supervisors cannot, for any reason, execute his duties or otherwise resigns, other members of the Board of Supervisors may appoint another $m$ ember to fill such vacancy until the next Regular/Annual Meeting of the Shareholders. In case the Board should be composed of two $\mathrm{m}$ embers, the vacancy should be filled until the next meeting of the Board of Directors.

ARTICLE 62: Committees:

The Board of Supervisors may appoint one or more committees consisting of two or more members of the Board of Supervisors, in order to investigate certain specific matters.

ARTICLE 63: Prohibition on Appointment of Relatives as Members of the Board of Supervisors:

Relatives of Members of the Board of Directors, such as a father, mother, brother, son, daughter, uncle, aunt, father-in-law, mother-in-law, or son-in -law, cannot be elected as members of the Board of Supervisors.

ARTICLE 64: Duties of the Board of Supervisors:

The following are the duties of the Board of Supervisors:

1. Cooperation with the Board of Directors in preparation and review of, the financial statements of the Corporation;

2. Investigation of the operations and books of the Corporation at least once every six months;

3. Inspection, without notice, of the treasury of the company at least once every three months;

4. Supervision of the actions of the Board of Directors with regard to the provisions of this law and as prescribed by the Articles of Incorporation and By-laws;

5. Notice of Regular/Annual or Special Meetings of the Shareholders if such duties are not fulfilled by the Board of Directors; and

6. Attendance at General Meetings of Shareholders;

7. To call Special Meetings of the Shareholders in cases of importance or emergency.

8. The Board of Supervisors must present to the Regular/Annual Meeting of Shareholders the result of its reviews of the financial statements and other accounts of the Corporation and the distribution of profits. 
ARTICLE 65: No Limitation of Authority for the Board of Supervisors:

The authority of the Board of Supervisors as set forth herein cannot be limited in the Articles of Incorporation or the By-laws.

ARTICLE 66: Execution of Duties by the Board of Supervision in Good Faith:

(1) The Board of Supervisors shall execute its duties in good faith and in the best interests of the Corporation and its Shareholders.

(2) The Board of Supervisors shall supervise the conduct of and implementation of actions and responsibilities by the Board of Directors.

(3) The bringing of a case against the Board of Supervisors for misconduct is invalid five years after the date of the action or inaction in question.

ARTICLE 67: Complaint against the Board of Directors:

Shareholders may refer to the Board of Supervisors any complaint against the Board of Directors of the Corporation, which shall properly investigate all such complaints and take all reasonable and appropriate action required as a result of such matter.

ARTICLE 67: Participation by the Board of Supervision in Meetings of the Board of Directors The Board of Supervisors may attend and participate in Meetings of the Board of Directors, but shall not be entitled to vote.

\section{CHAPTER TEN}

\section{SHAREHOLDER MEETINGS}

ARTICLE 69: General Meetings of the Shareholders:

(1) Meetings of the Shareholders of the Corporation may be either Regular /Annual or Extraordinary [Special]. The Regular/Annual Meeting is to take place within four months after the end of the Corporation's fiscal year, or at such other time as is provided for in the Corporation's Articles of Incorporation, provided, however, that the Regular/Annual Meeting shall be convened at least once each calendar year.

(2) The Regular/Annual Meeting shall be held at the Corporation's principal office, or at such other place as may be designated by the Board of Directors, either within or outside of Afghanistan. The Board of Directors may determine the place for a Meeting. When needed, the meetings may be held by means of remote communication as permitted in this Law.

(3) The failure to hold the Regular/Annual Meeting at the time or place stated in the Articles of Incorporation does not affect the validity of any action by the general meeting of the Shareholders.

ARTICLE 70: Remote Communication:

If authorized by the Articles of Incorporation, the By-laws, or the Board of Directors, and subject to such guidelines and procedures as the Board of Directors may adopt, Shareholders and proxy holders not physically present at an Regular/Annual Meeting may, by means of remote communication such as telephonic or video conference participate in an Regular/Annual or Special Meeting and be deemed present in person and vote at such Meeting. 
ARTICLE 71: Extraordinary [Special] Meetings:

(1) A Corporation shall hold a Special Meeting of the Shareholders:

1. On the call of its Board of Directors or the person or persons authorized to do so by the Articles of Incorporation or By-laws; or

2. If Shareholders controlling at least 10 percent of the votes entitled to be cast on an issue request, in writing, a Meeting of the Shareholders. The request must be signed and dated by the requesting Shareholder, or Shareholders, and must describe the purposes for which the Special Meeting will be held. A Corporation's Articles of Incorporation may fix a lower percentage, or a higher percentage not exceeding 25 percent, of all of the vote s entitled to be cast.

(2) The only matters to be discussed and voted upon at the Special Meeting are such matters as are included in the notice of the Meeting.

(3) The record date for determining qualified Shareholders entitled to demand a Special Meeting is as determined by the administration of the Corporation. Such invitation shall be on the date the last Shareholder signs the request for a Special Meeting.

(4) Special Meetings may be held at the place established in the By-laws, or as determined by the Board of Directors, including participation by remote communication as provided in this law.

ARTICLE 72: Court-Ordered Meeting:

(1) The Commercial Court may call a Meeting of the Shareholders in the following cases:

1. Any Shareholder of the Corporation entitled to participate in Regular/Annual Meetings, if such Meeting was not held within four months after the end of the Corporation's fiscal year, in accordance with Article 69 (1) of this law;

2. A Shareholder who made a valid request for a Special Meeting, if pursuant to ARTICLE 71 paragraph (1), section 2, the Special Meeting was not held.

ARTICLE 73: Decisions without a Meeting:

(1) Action required, or permitted, by provision of this law to be taken at any Meeting of the Shareholders may be taken without a Meeting if the action is taken in writing by the Shareholders entitled to vote on the action as set forth herein. The action must be submitted in writing, dated and signed to the Shareholders owning at least the number of Shares required. If a written action is taken by fewer than all the Shareholders, written notice of the action taken shall be sent promptly to all Shareholders. All written actions, as set forth herein, shall be delivered to the Corporation for inclusion in the Minutes, or filing with the corporate records. If not otherwise set, the Record Date for determining Shareholders entitled to take action Without a Meeting is the date the first Shareholder signs the written action. Written actions shall be effective to take the corporate action referred to therein, provided, that if the written action is taken by less than all of the Shareholders as provided in paragraph (1) of this ARTICLE and/or the notice of such proposed action is required to be given to any nonvoting Shareholders, such written actions may be effective no earlier than 20 days after notice of such action is delivered to Shareholders. A Shareholder may revoke his consent to a written action by delivering a revocation in writing to the Corporation prior to receipt by the Corporation of written consents sufficient in number to take the proposed corporate action. A written action under paragraph (1) of this ARTICLE has the effect of a Meeting vote and may be described as such in any document.

(2) Any notices and consents required to be delivered under this ARTICLE may be delivered via Electronic Transmission. 
ARTICLE 74: Notice of Meeting:

(1) The notice of a Meeting of the Shareholders is to be given as provided in the Corporation's Articles of Incorporation, or By-laws, provided, however, that the Corporation shall notify Shareholders of the date, time and place of each Meeting, and the means of $r$ emote communication, if any, no fewer than 10 nor more than 60 days before an Regular/Annual Meeting date and no fewer than five days before a Special Meeting date. The Corporation is required to give notice only to those Shareholders entitled to vote at the Meeting.

(2) If not otherwise set by the Board of Directors in the By-laws, the Record Date for determining Shareholders entitled to notice of and vote at a Regular/Annual or Special Meeting is the day before the first notice is delivered to the Shareholders.

(3) Unless the Corporation's Articles of Incorporation or By-laws specify otherwise, if an Regular/Annual or Special Meeting is adjourned to a different time, date or place, notice need not be given of such new time, date or place if the new time, date or place is announced at the Meeting prior to adjournment. If a new Record Date for the adjourned Meeting is fixed, notice of the adjourned Meeting must be given to Persons who are Shareholders of Record as of the new Record Date.

ARTICLE 75: Method of Invitation:

(1) Without limiting the manner by which notice otherwise may be given to Shareholders, any notice to Shareholders given by the Corporation (as provided in this Law, the Articles of Incorporation, or the By-laws) shall be effective if given by a form of Electronic Transmission (including electronic mail) consented to by the Shareholder to whom the notice is given. Any such consent shall be revocable by the Shareholder by written notice. Any such consent shall be deemed revoked if the Corporation is unable to deliver by Electronic Transmission two consecutive notices.

(2) The Board of Directors may decide concerning the notice referred to in paragraph (1) of this Article if the written agreement and signature by other members of the Board of Directors have been received by electronic transmission.

(3) Notice given pursuant to paragraph (1) above, shall be deemed given:

1. if by facsimile telecommunication, when directed to a number at which the Shareholder has consented to receive notice;

2. if by electronic mail, when directed to an electronic mail address at which the Shareholder has consented to receive notice;

3. if by a posting on an electronic network together with separate notice to the Shareholder of such specific posting, upon the later of: (i) such posting, and (ii) the giving of such separate notice; or

4. by any other form of Electronic Transmission, when directed to the Shareholder.

(4) An affidavit of an Officer of the Corporation that the notice has been given by a form of Electronic Transmission shall be conclusive evidence of the facts stated therein.

ARTICLE 76: Notice of Invitation to those Sharing an Address:

Without limiting the manner by which notice otherwise may be effectively given to Shareholders, any notice to Shareholders given by the Corporation shall be effective if given by a single written notice to Shareholders who share an address if consented to by the Shareholders at that address to whom such notice is given. Any such consent shall be revocable by the Shareholder by written notice to the Corporation. 
ARTICLE 77: Waiver of Notice:

A Shareholder may waive any required notice before or after the date and time stated in the notice when the shareholder can not attend the meeting. The waiver must be in writing, signed by the Shareholder entitled to the notice and delivered to the Corporation for inclusion in the Minutes or filing with the corporate records. A Shareholder's attendance at a Meeting, whether such attendance be in person or otherwise, waives objection to lack of notice or defective notice of the Meeting, unless the Shareholder at the beginning of the Meeting objects to holding the Meeting or transacting business at the Meeting.

ARTICLE 78: Shareholders Eligible to Receive a Notice:

The By-laws of the Corporation, or the Board of Directors, may set, or provide for, the manner of setting the Record Date in order to determine: the Shareholders entitled to notice of a Meeting of the Shareholders; to demand a Special Meeting; to vote; or to take any other action.

ARTICLE 79: Conduct of the Meeting:

(1) The Chairman of the Board of Directors, or his designee, shall preside over each Meeting of the Shareholders and shall, unless the Articles of Incorporation, or By-laws, provide otherwise, determine the order of business (consistent with the agenda) and shall have the authority to establish rules for the conduct of the Meeting.

(2) If a quorum is present, the Chairman, or his designee, shall conduct voting for each matter in accordance with the agenda. When voting is completed the matter shall not be brought under discussion in the event of an objection.

(3) At the Meeting of the Shareholders a List is to be made of all Shareholders, or their representatives, who are present and their documents and papers and their respective Share ownership. The List shall be signed by the Chairman, or his designee, and, together with other papers and records with respect to the Meeting, and shall be kept by the Corporation in its records.

(4) A copy of the decisions of the Regular/Annual and Special Meetings, together with the Voting and other information relating to such Meetings, shall be prepared and kept by the Corporation.

ARTICLE 80: Shareholders List:

(1) After setting a Record Date for a Meeting, the Corporation shall prepare a written List of the names of all of its Shareholders who are entitled to notice of the Meeting and show the address of and number of Shares held by each Shareholder. The Shareholders' List must be available for inspection by any Shareholder for any purpose related to the Meeting beginning two business days after notice of the Meeting and continuing through the Meeting.

(2) If the Meeting is held solely by means of Remote Communication the List shall also be open to examination by any Shareholder on a reasonably accessible electronic network and the information required to access such List shall be provided with the notice of the Meeting. (3) Refusal or failure to prepare, or make available, the Shareholders' List does not affect the validity of action taken at the Meeting.

ARTICLE 81: Voting Right of Shareholders: 
(1) Except as provided in parts (2) and (3), below, or unless the Articles of Incorporation provide otherwise, each outstanding Share, is entitled to one vote.

(2) The Shares of a Corporation are not entitled to vote if they are owned, directly or indirectly, by a second Corporation (Domestic or Foreign), even if it owns a majority of the voting stock of the Corporation. This provision does not limit the power of a Corporation to vote any Share s, including its own Shares, held by it in a fiduciary capacity.

(3) Redeemable Shares are not entitled to vote after notice of redemption is mailed to the holders and a sum sufficient to redeem the Shares has been deposited with a bank, or other financial institution, under an irrevocable obligation to pay such redemption price.

ARTICLE 82: Participation in Voting:

(1) A Shareholder may vote his Shares in Person or by Proxy.

(2) A Shareholder may appoint a Person to vote, or otherwise act for the Shareholder (a

"Proxy"), by signing an appointment form, or by an Electronic Transmission. A Corporation is entitled to accept the Proxy's vote, or other action, as that of the Shareholder making the appointment. An Electronic Transmission must contain, or be accompanied by, information proving that the Shareholder authorized the Transmission. An appointment of a Proxy is effective when a signed appointment form, or an Electronic Transmission, of the appointment is received the Corporation. An appointment may be valid for a period as agreed by the parties. (3) An appointment of a Proxy is revocable unless the appointment form, or Electronic Transmission, states that it is irrevocable. The appointment requires that the Corporation considers an interest sufficient in law for the shareholder. An appointment made irrevocable hereunder is revoked when the interest with which it is coupled is terminated. Appointments coupled with an interest include the appointment of:

1. A Creditor of the Corporation who extended it s credit under certain terms;

2. An Employee of the Corporation whose employment contract requires the appointment; 3. A Party to a Voting Agreement created under this Law.

(4) The death, or incapacity, of the Shareholder appointing a Proxy does not affect the right of the Corporation to accept the Proxy's authority until the Corporation has knowledge of such death or incapacity. A person that purchases Shares subject to an irrevocable Proxy appointment may revoke the appointment if he had no knowledge of its existence when he acquired the Shares and the irrevocable appointment was not stated on the Stock Certificate.

ARTICLE 83: Effectiveness of Documents:

(1) If the name signed on a vote, consent, waiver, or Proxy appointment corresponds to the name of a Shareholder, the Corporation is entitled to give it effect. If the name of the Person taking such actions does not match the Corporation's Shareholder records, the Corporation is entitled to accept a vote, consent, waiver, or Proxy appointment from such Person as if it was act of the Shareholder if:

1. The Shareholder is a legal person and it is signed by an Officer or proper agent of the Entity;

2. The name signed is either:

(i) an administrator, executor, guardian, or conservator representing the Shareholder and, if the Corporation's request, presents evidence of fiduciary authority acceptable to the Corporation with respect to the vote, consent, waiver, or Proxy appointment;

(ii) a receiver, or Trustee in bankruptcy of the Shareholder;

(iii) the Person to whom a power of attorney has been given by the Shareholder; 
3. Two or more Persons are the Shareholder as co-tenants, or fiduciaries, and at least one of the co-owners or fiduciaries signs such document or takes such action. The Corporation is entitled to reject a vote, consent, waiver, or Proxy appointment if the Secretary has reasonable doubt about the validity of the signature thereon, or about the signatory's authority to sign for the Shareholder. In such case the Corporation is not liable in damages to the Shareholder for the consequences the acceptance or rejection].

\section{ARTICLE 84: Quorum:}

(1) A Quorum for a Meeting of the Shareholders is as prescribed in the Articles of Incorporation, and if not so prescribed therein as provided for under this Law; provided that the Articles of Incorporation may not specify a Quorum less than one-fourth of the number of Shares entitled to vote on any matter or take any action at the Meeting.

(2) In the absence of such specification in a Corporation's Articles of Incorporation:

1. A majority of Shares entitled to vote, present in Person (or by Proxy), shall constitute a Quorum at an Regular/Annual Meeting of the Shareholders;

2. In all matters, other than the election of Directors, the affirmative vote of a majority of the Shares present in Person (or by Proxy) at the Meeting and otherwise entitled to vote shall constitute the Act of the Shareholders;

3. Directors shall be elected by a plurality of votes of the Shares present in Person (or by Proxy) at the Meeting and entitled to vote on the election [of Directors];

4. Where Shareholders are divided into specific classes or series, in consideration of the amount of Shares, if separate votes of each class or series is required a majority of the outstanding Shares of such class or series, present in Person (or by Proxy), shall constitute a quorum entitled to take action with respect to that vote on that matter and the affirmative vote of the majority of Shares of such class or series present in Person (or by Proxy) at the Meeting shall be the act of such class or series.

(3) If a quorum is not present, the Meeting of the Shareholders shall be adjourned until such other time, date, and location shall be set by the Board of Directors and announced prior to adjournment. Notice for such subsequent Meeting shall be provided to all Shareholders as otherwise required in this Law only if the time, date, and location of the next Meeting are not announced prior to adjournment.

(4) Once a Share is represented for any purpose at a Meeting it is deemed present for Quorum purposes for the remainder of the Meeting and for any adjournment of the Meeting unless a new Record Date is set for the adjourned Meeting.

ARTICLE 85: Electing Directors:

(1) All elections of Directors shall be by written ballot, unless otherwise provided in the Corporation's Articles of Incorporation or By-laws. If authorized by the Board of Directors such requirement of a written ballot shall be satisfied by a ballot submitted by Electronic Transmission, as provided in this Law.

(2) Unless otherwise provided in the Articles of Incorporation or By-laws, Directors are elected by a plurality of the vote s cast.

(3) Shareholders do not have a right to cumulate their votes for Directors unless the Articles of Incorporation specifically provide otherwise. Cumulative Voting means that the Shareholders so designated are entitled to multiply the number of vote $s$ they are entitled to cast by the number of 
Directors for whom they are entitled to vote and then cast the total number of votes for a single candidate, or distribute the product among two or more candidates.

ARTICLE 86: Appointing Inspectors:

(1) Corporation may appoint one or more Persons to act as the inspector(s) and administrator(s) of the voting procedures and the votes at a Meeting of the Shareholders with the duties as determined by the Board of Directors

(2) Inspectors or administrator shall make a written report to the Board of Directors.

ARTICLE 87: Keeping Documents and Records:

(1) Any records maintained by a Corporation in the regular course of its business, including its stock ledger, books of account, and Minute books may be kept on, or by means of, or be in the form of, any information storage device or method, provided that the records are clear, in legible form and usable.

(2) Any Corporation shall make available such documents and records upon the request of any Person entitled to inspect them, in accordance with this law. Such records and documents shall be admissible in evidence and accepted for all purposes, to the same extent as an original paper record of the same information would have been, provided the paper form accurately portrays the record.

(3) Any Shareholder, in Person or by attorney, or other agent, shall, upon written demand stating the purpose thereof, have the right during the usual hours for business, to inspect for any proper purpose the Corporation's stock ledger, a List of its Shareholders, and its other books and records, and to make copies or extracts there from. In this Article, a proper purpose shall mean a purpose reasonably related to such Person's interest as a Shareholder of the Corporation. In every instance where an attorney, or other agent, shall be the Person who seeks the right to inspection, the demand shall be accompanied by a power of attorney, or such other writing, which authorizes the attorney, or other agent, to so act on behalf of the Shareholder. To the extent made available by the Corporation, any Shareholder may receive and/or view such stock ledger, Shareholder List and other books and records on an electronic network, as provided and subject to the restrictions under this Law.

(4) Any Director shall have the right to examine the Corporation's stock ledger, a List of its Shareholders and its other books and records for a purpose reasonably related to the Director's position. The Commercial Court is vested with the jurisdiction to prescribe the inspection by a Director, or Shareholder.

ARTICLE 88: Voting Trusts:

(1) One or more Shareholders may create a Voting Trust conferring on a Trustee the right to vote, or otherwise act for them, by signing an agreement setting out the provisions of the Trust (which may include anything consistent with its purpose) and transferring their Shares to the Trustee. When a Voting Trust Agreement is signed, the Trustee shall prepare a list of the names and addresses of all owners of beneficial interests in the Trust and deliver copies of the list and Agreement to the Corporation's principal office.

(2) A Voting Trust becomes effective on the date the first Shares subject to the Trust are registered in the Trustee's name. A Voting Trust is valid for not more than 10 years after its Effective Date unless extended for a maximum of another 10 years. An extension shall be delivered to the Corporation's principal office. 
ARTICLE 89: Voting Agreements:

Two or more Shareholders may enter into an agreement providing their agreement regarding the manner in which they will vote their Shares.

ARTICLE 90: Concluding Agreements Governing Management of Affairs and Business: (1) The Shareholders may enter into an Agreement governing the exercise of the corporate power, or the management of the business and affairs of the Corporation among the Shareholders, the Directors and the Corporation, or among any of them.

(2) An Agreement authorized by paragraph (1) of this Article shall be set forth either in: 1. the Articles of Incorporation, or Bylaws, and approved by all Persons who are Shareholders at the time of the Agreement; or 2. a written Agreement signed by all Shareholders at the time of the Agreement and made known to the Corporation. Shareholder Agreements under this ARTICLE may be amended only by all Persons who are Shareholders at the time of the amendment. Shareholder Agreements are valid for 10 years, unless the Agreement provides otherwise. (3) The existence of a Shareholder Agreement authorized by paragraph (2) shall be valid when noted in the Articles of Incorporation and on the front or back of each Stock Certificate. The failure to note the existence of the Agreement on the certificate or information statement shall not affect the validity of the Shareholder Agreement, or any action taken pursuant to it. Any purchaser of Shares who, at the time of purchase, did not have knowledge of such Agreement shall be entitled to rescission of the purchase. A purchaser shall be deemed to have knowledge of the Agreement if its existence is noted on the Stock Certificate. An action to enforce the right of rescission must be commenced within the earlier of 90 days after discovery of the existence of the Shareholder Agreement or two years after the time of purchase of the Shares.

(4) A Shareholder Agreement may limit the powers of the Board of Directors and impose upon

the Person or Persons in whom such discretion or powers are vested, liability for acts or omissions imposed by law on Directors to the extent that the discretion, or powers of the Directors are limited by the Shareholder Agreement.

(5) The existence or performance of a Shareholder Agreement mentioned in this Article shall not be a ground for imposing person al liability on any Shareholder for the acts or debts of the Corporation even if the Agreement, or its performance, treats the Corporation as if it were a partnership, provided that the corporate formalities otherwise applicable to the matters governed by the Agreement are failed to observe and implement.

\section{CHAPTER TWELVE DISTRIBUTION OF DIVIDENDS TO SHAREHOLDERS}

ARTICLE 91: Announcement of Capital:

The Board of Directors may declare and cause the Corporation to pay Dividends upon Shares of the Corporation's Capital Stock, subject to the Corporation's Articles of Incorporation and the limitations in this law.

ARTICLE 92: Distributions of Dividends:

(1) No distribution of Dividends may be made if:

1. The Corporation would not be able to pay its obligations or debts as they became due; or

2. The Corporation's [total] assets would be less than the sum of its total liabilities 
3. The Corporation's Reserved Capital would be less than five percent of all shares (2) Distributions made contrary to paragraph (1) of this Article illegally, the provisions of ARTICLE 49 hereto will apply to such distributions.

(3) In case the Corporation was to dissolve at the time of distribution, the rights of persons with preferential rights shall be superior to those of persons receiving the dividends, unless provided otherwise in Articles of Incorporation.

\section{ARTICLE 93: Reserve Capital}

In distribution of profits, at least $5 \%$ of the profits shall be retained as Reserve Capital to compensate for possible losses of the company. No further amount shall be retained as Reserve Capital thus collected after such capital reaches at least $25 \%$ of the company's capital, provided that the charter does not stipulate a higher percentage. Where the price of Shares exceeds their designated value, the additional value may also be retained as Reserve Capital. Where the Reserve Capital reaches the level determined in the Article of Incorporation or law, but subsequently decreases due to any reason, profits shall be retained in accordance with paragraph (1) in the order specified therein until such loss is recovered.

ARTICLE 94: Payment of Dividends:

Dividends may be paid in cash, in property, or in Shares of the Corporation's Capital Stock.

\section{CHAPTER TWELVE}

MATERIAL CHANGE TO CORPORATE STRUCTURE:

ARTICLE 95: Amendment of Articles of Incorporation:

(1) The shareholders may amend, increase or omit the provisions of the articles of incorporation.

(2) The Board of Directors must approve and recommend the proposed amendment to the

Shareholders and the Shareholders entitled to vote on the amendment have the right to approve the amendment by a majority of the votes entitled to vote on such proposed action.

(3) Unless the Articles of Incorporation provide otherwise, a Corporation's Board of Directors may adopt and approve one, or more, of the following amendments to the Articles of Incorporation without Shareholder approval:

- to delete the names and addresses of: the initial Incorporators;

- to delete the initial principal office;

- to delete the Initial Directors; or initial responsible agent (if current responsible agent information is on file with the Central Registry ).

ARTICLE 96: Increase in Capital of the Corporation:

If the Board of Directors, in its written judgment, determines to increase the authorized capital of the Corporation by increasing the amount of authorized Shares available for issuance, or by creating new classes or series of stock, the Board of Directors shall approve and submit the matter for vote by the Shareholders. Issuance of authorized Share s shall be regulated by ARTICLES 30 and 31 of this Law.

ARTICLE 97: Pre-emptive Rights:

Unless otherwise expressly provided in the Corporation's Articles of Incorporation, or as

determined by the Board of Directors, upon any increase in the authorized capital of the 
Corporation, or issuance of additional Shares by the Corporation, the existing Shareholders are not entitled to preemptively purchase, or subscribe for their pro rata Share of any such newlyauthorized, or newly -issued Shares of Capital Stock.

\section{CHAPTER THIRTEEN} STOCK CERTIFICATES

ARTICLE 98: Stock Certificates:

(1) The issued and outstanding Shares of Capital Stock of a Corporation may be represented by Stock Certificates, as provided in the Corporation's Articles of Incorporation, or By-laws. At minimum, each Stock Certificate must state the name of the issuing Corporation, the jurisdiction of the organization, the par value, the name of the Person to whom it is issued and the number and class of Shares issued, and shall be signed by two authorized Officers of the Corporation. (2) Any or all the signatures on the Certificate may be a facsimile. If the Person who signed a Certificate shall have ceased to be an Officer of the Corporation after such Certificate is issued, the Certificate shall remain valid.

ARTICLE 99: Transfer of Shares:

Unless otherwise stated in the Articles of Incorporation, Shares are transferable to others without the consent of the Corporation.

ARTICLE 100: Registration of Shares and Validity thereof:

Shares are transferred to others by endorsement or by another written document. In order for this transfer to be honored it must be registered in the Share Registration Book of the Corporation.

ARTICLE 101: Unpaid Shares:

When the consideration payable for Shares of a Corporation has not been paid in full, and the assets shall be insufficient to satisfy the claims of its Creditor s, each holder of, or subscriber for, such Shares shall be bound to pay on each Share held or subscribed for by such holder, or subscriber, the sum necessary to complete the amount of the unpaid balance of the consideration for which such Share s were issued, or are to be issued, by the Corporation.

ARTICLE 102: Unusable Stock Certificates:

(1) A Stock Certificate should become in such bad condition that its further use is impractical, but its contents and distinguishing marks are perfectly legible, its owner is entitled to pay the expenses involved and receive replacement Stock Certificates from the Corporation.

(2) A Corporation shall issue a new Stock Certificate in place of any existing Certificate that has been lost, stolen, or destroyed and the Corporation may compensate for damages in case of any claim concerning the mentioned Certificate. The Corporation may require the owner of such former and replacement Stock Certificate s to indemnify the Corporation against any claim that may be made against the Corporation relating to such Certificate. The Corporation may require the owner of the lost, stolen, or destroyed Stock Certificate to provide the Corporation with a bond sufficient to cover such indemnification obligations.

CHAPTER FOURTEEN

DISSOLUTION AND LIQUIDATION OF CORPORATIONS 
ARTICLE 103: Dissolution of Corporations:

The Board of Directors may approve the dissolution of the Corporation by majority of votes and present the proposal (whether conditional or unconditional) to Shareholders meeting for adoption and approval.

ARTICLE 104: Registration of Articles of Dissolution:

(1) As provided in article 103 , the Corporation may deliver to the Central Registry for filing Articles of dissolution setting forth:

1. The name of the Corporation;

2. The date on which dissolution was authorized by the Board and Shareholders;

3. A statement that the proposal to dissolve was duly approved by the Shareholders in the manner required by this Law and by the Articles of Incorporation.

(2) The Corporation shall be dissolved upon the date of registering the Articles of dissolution.

(3) "Dissolved Corporation" means a Corporation whose Articles of Dissolution has become effective and includes a successor entity to which the remaining assets of the Corporation are transferred subject to its liabilities for purposes of liquidation.

ARTICLE 105: Non-Issuance of Shares and Demanding Dissolution:

(1) A majority of the Incorporators or Initial Directors of a Corporation that has not issued Shares may dissolve the Corporation by delivering to the Central Registry for filing Articles of Dissolution that set forth:

1. The name of the Corporation;

2. The date of its Incorporation;

3. A statement that: (i) none of the Corporation's Shares has been issued;

4. That no debt of the Corporation remains unpaid;

5. That a majority of the Incorporators, or Initial Directors, authorized the dissolution.

ARTICLE 106: Revocation of Dissolution:

(1) The general meeting of Shareholders of a Corporation may revoke its dissolution within five days of its Registration and advertisement date. Revocation of dissolution must be authorized in the same manner as the dissolution was authorized. After the Revocation of dissolution is authorized, the Corporation may revoke the dissolution by delivering to the Central Registry for filing Articles of Revocation of dissolution that set forth:

1. The name of the Corporation;

2. The announcement date for revoking the dissolution;

3. The date that the revocation of dissolution was authorized by the Corporation's Board of Directors and Shareholders (if Shares issued).

When the revocation of dissolution is effective, the Corporation resumes carrying on its business as if dissolution had never occurred. Revocation of dissolution is retroactive.

ARTICLE 107: Grounds for Judicial Dissolution:

(1) The Commercial Court of proper jurisdiction may dissolve a Corporation:

1. in a proceeding initiated by the Ministry of Commerce and Industry, if it is established that:

i. The Corporation obtained its Certificate of Incorporation through fraud;

ii. The Corporation has exceeded, or abused, the authority conferred upon it by Law. 
2. by one or more Shareholders if it is established that:

i. The Directors are deadlocked in the management of the Corporation's affairs, the Shareholders are unable to break the deadlock, and irreparable injury to the Corporation and its assets is being suffered;

ii. The Directors or those in control of the Corporation have acted, or are acting, in a manner that is illegal or fraudulent;

iii. The Shareholders are deadlocked in voting power and have failed, for a period that includes at least two consecutive Regular/Annual Meetings, to elect Directors.

3. by a creditor if it is established that:

i. The creditor's claim: (i) has been reduced to judgment; and (ii) the execution on the judgment is unsatisfied; and (iii) the Corporation is insolvent; or

ii. The Corporation has admitted in writing that the creditor's claim is due and owing and the Corporation is insolvent.

iii. When a claim is filed against the Corporation, the Corporation's voluntary dissolution shall be executed under Court supervision.

ARTICLE 108: Receivership or Custodianship:

(1) In a Court Proceeding brought to dissolve the Corporation, a Court may appoint one or more receivers to wind up and liquidate, or one or more custodians to manage the business and affairs of the Corporation during such dissolution.

(2) Court appointed receivers must be an individual, or a domestic or foreign Corporation, unaffiliated in any way with the Corporation to be dissolved. The receiver or custodian must receive no benefit from his/her position other than reasonable compensation and reimbursement of expenses from the assets of the Corporation or proceeds of its sale.

(3) The Court shall describe the powers and duties of the receiver or custodian in its appointing order, which may be amended from time to time. Among other powers the receiver may:

1. Dispose of all or any part of the assets of the Corporation wherever located, at a public or private sale, if authorized by the Court;

2. Sue and defend in his all proper courts.

(4) The custodian may exercise all of the powers of the Corporation through or in place of the Board of Directors to the extent necessary to manage the affairs of the Corporation in the best interests of its Shareholders and creditors.

ARTICLE 109: Decree of Dissolution:

If the Court determines that one or more grounds for judicial dissolution exist, it may enter a decree dissolving the Corporation in accordance with Article 107 of this law and specify the announcement date of the dissolution.

The Court shall deliver a certified copy of the decree of dissolution to the Central Registry. After entering the decree of dissolution, the Court shall direct the winding up and liquidation of the Corporation's business and affairs.

CHAPTER FIFTEEN

MISCELLANEOUS PROVISIONS

ARTICLE 110: Existence of Established Corporations before the Adoption of This Law: 
The Corporations and limited companies which have been licensed prior to the effective date of this law, based on the provisions of the Commercial Code, or have obtained business licenses from other authorized commercial agencies and have registered the licenses in the offices for commercial documents and trademarks, shall upon the adoption of this law within a period of one year and six months reregister in the Central Registry. In such a case, their legal existence shall continue and they shall be subject to provisions of this law.

ARTICLE 111: Proposing Regulations and Internal Rules

For better implementation of this law, the Ministry of Commerce may propose regulations and enact relevant procedures.

ARTICLE 112: Payment of Tax:

Corporations and limited labiality companies and their shareholders referred to in this law shall pay tax according to the provisions of applicable law.

ARTICLE 113: Registration of Fraudulent Documents:

A person who intentionally signs a fraudulent document and forwards it for registration to the Central Registry shall be punished according to the provisions of the penal code.

ARTICLE 114: Effective Date:

This law is effective from the date of promulgation and shall be published in the Official Gazette. Upon the effectiveness of this law, all provisions concerning corporations and limited liability companies in the commercial code of Afghanistan, published in Official Gazette \# 89, of 1336 [1957] and the Civil Code, dated, 15, 10, 1355 [1976] and any other legal provisions which are contrary to the provisions of this law shall be null and void. 


\section{PRIVATE INVESTMENT LAW}

Draft of October 8, 2005

Chapter One

GENERAL PROVISIONS

Article 1: Preamble

This Law is enacted based upon the provision of Article Ten of the Constitution of Afghanistan for encouraging, promoting, protecting and securing investments and private businesses established according to the free market economic system and regulating its related affairs.

Article 2: The Purpose of Legislation

The purposes of this Law are to maximize the role of private investment, both domestic and foreign, in the economy, to create a legal regime and administrative structure that will encourage and protect foreign and domestic private Investment in the Afghan economy in order to promote economic development, expand the labor market, increase production and export earnings, promote technology transfer, improve national prosperity and advance the people's standard of living.

Article 3: Definitions

The terms below shall have the following meanings:

"Capital Assets" shall mean capital assets including, without limitation, equipment and machinery.

"Commission" shall have the meaning set forth in Article 6 of this Law.

"Foreign Investment" shall mean Investment in the form of freely convertible foreign currency or contributions in kind (in each case transferred from outside Afghanistan) that has been provided by a Foreign Person.

"Foreign Investor" shall mean a Foreign Person who has provided Foreign Investment.

"Foreign Loan" shall mean a loan, debenture, bond or other form of debt extended to a Registered Enterprise in freely convertible foreign currency by a Foreign Person for the purpose of enabling the Registered Enterprise to carry on its business in Afghanistan.

"Person" shall mean:

- "Natural Domestic Person" shall mean an individual whose identity is recognized by applicable laws.

- "Legal Domestic Person" shall mean a person that has been constituted or organized in the form of a corporation, partnership, sole proprietorship, limited liability company, joint venture, association, joint stock company, trust or other entity under the applicable law.

- "Natural Foreign Person" shall mean an individual who has the citizenship of other than Afghanistan.

- "Legal Foreign Person" shall mean a person that has been constituted or organized under laws other than the laws of Afghanistan

- "Infrastructure" shall mean any facility or service that is used by and/or provided for the benefit of members of the public (or any section of the public) and shall include, without limitation:

- Power generation or transmission facilities;

- Water delivery or treatment facilities; 
- Sewerage or sewage treatment facilities;

- Waste-treatment or disposal facilities;

- Airport facilities and facilities in health and education sectors;

- Telecommunications and broadcasting facilities;

- Other service or facility that is designated by the relevant authorities as Infrastructure for the purpose of this Law.

- "Investment" shall mean currency and contributions in kind, including, without limitation, licenses, leases, machinery, equipment, and industrial or intellectual property rights, provided for the purpose of acquiring shares of stock or other ownership interests in a Registered Enterprise.

- "Investor" shall mean a Person who has provided an Investment.

- "Natural Resources" shall mean reserves, reservoirs or deposits of whatever nature of oil, gas, gold, silver, coal or any other minerals, hydrocarbons or other resources and whether in their natural state or after any kind of treatment.

- "Office" shall mean the Afghan Investment Support Agency, established pursuant to Article 8(2) of this Law.

- "Registered Enterprise" shall mean a business entity registered pursuant to the procedures set forth in Articles 12.

- "ICSID" shall have the meaning set forth in Article 30.

- "UNCITRAL Rules" shall mean the arbitration rules of the United Nations Commission on International Trade Law.

Article 4: Permitted Investment

(1) Except as otherwise set forth in Article 5 of this Law, all Foreign or Domestic Persons may make investments in all sectors of the economy.

(2) A Foreign Person may only make an Investment in Afghanistan through a Foreign Investment in a Registered Enterprise or through reinvestment from an existing Registered Enterprise.

Article 5: Areas Where Investment May Be Prohibited, Restricted or Subject to Special Terms (1) Investments in the following areas are prohibited:

1. development of nuclear power;

2. establishment of casinos and gambling establishments; and

3. production of narcotics and intoxicants;

Except for part (2) of the above, the Commission may from time to time add to or otherwise amend and regulate the prohibition of these sectors considering national interest.

(2) The Commission may from time to time limit the foreign beneficial ownership of business entities operating in certain industries or economic sectors, PROVIDED, HOWEVER, that any such limitation or limitations shall be prospective only and shall not apply to any existing Investment in a Registered Enterprise.

(3) The Commission must discuss with appropriate ministries, and approve, with the consent of such ministry or ministries, on a case-by-case basis, investment in certain sectors of the economy (and certain types of Investment). With respect to such investments, the Commission may choose to apply terms that are different from those generally applied to Investments pursuant to this Law, PROVIDED, HOWEVER, that the Ministry of Finance must approve any revenue related 
incentives that are more generous than those set forth in the Law. The initial list of such restricted sectors is set forth below:

- production and sale of weapons and explosives;

- non-banking finance activities;

- insurance activities; and

- Investments in Natural Resources (including forestry) and Infrastructure (including pipeline construction and operation), but only until special laws, if any, have been promulgated that are applicable to and govern such Investments after which such Investments shall be governed by such special laws, The Commission may from time to time add to or otherwise amend and regulate the list of such sectors.

Chapter Two

ADMINISTRATION AND MONITORING

Article 6: Administrative Structure

(1) The High Commission on Investment, (hereafter called the "Commission") shall be constituted the highest governing authority in policy-making on Investment for better implementation of this Law.

(2) To assist it in carrying out its duties, the Commission shall establish the Office as a limited liability company. The Chief Executive Officer, as the head of the Office, shall be appointed by the President of the Islamic State of Afghanistan based upon the recommendation of the Chairman of the Commission and shall be responsible to the Commission.

(3) The Commission shall have the authority to appoint a board of director and a supervisory board to monitor the Office in carrying its duties pursuant to part (2) of this article.

Article 7: Composition of the Commission

(1) The Commission shall be composed of:

1. The Minister of Commerce,

2. The Minister of Foreign Affairs,

3. The Minister of Finance,

4. The Minister of Economy,

5. The Minister of Mines and Industries,

6. The Minister of Agriculture,

7. The Governor of Da Afghanistan Bank, and,

8. The Chief Executive Officer of the Office, as a non-voting member and as the secretary.

Further, the Commission is authorized to invite representatives from the private sector to provide consultation and comment to the Commission, when and if desired by the Commission.

(2) The Minister of Commerce shall serve as Chairman of the Commission. In his absence, a person among the voting members shall be appointed by him to chair the meetings. The Chief Executive Officer of the Office shall serve as Secretary of the Commission.

(3) If the Commission determines that one of its proposed actions may significantly affect Investment projects or policies in a particular sector which is not represented on the Commission, the relevant Minister(s) shall be invited to participate in the meetings of the Commission that relate to the proposed action.

(4) The President of the Islamic State of Afghanistan may alter the composition of the Commission. 
Article 8: Responsibilities of the Commission

The Commission shall have the following rights and responsibilities:

(1) To adopt bylaws establishing procedures for conducting its meetings and for making and recording decisions.

(2) To establish the Office (AISA) for carrying out its duties.

(3) To monitor the state of Investment in the country and propose to the authorized authorities

any modifications to this Law that it deems advisable.

(4) To propose rules to the Council of Ministers and to instruct the Office to draft such

procedures for promulgation by the Commission for the implementation of this Law. .

(5) To establish a threshold value (the "Threshold Value") for initial capital.

(6) To receive advice from the Office for recognizing Registered Enterprises where Investment is reasonably expected to be greater than or equal to the Threshold Value.

(7) To authorize the Office to recognize Registered Enterprises where Investment is reasonably expected to be less than the Threshold Value.

(8) To make decision on cases appealed from decisions by the Office not to recognize a

Registered Enterprise by written reasons.

Article 9: Responsibilities of the Office

In order to perform the work assigned it by the Commission, the Office shall have the following responsibilities:

1. To review applications by business entities for recognition as Registered Enterprises to the extent that it is so instructed by the Commission.

2. The Office shall establish procedures, which shall be subject to the approval of the

Commission, for the submission, review and registration of applications for Foreign and domestic Investment.

3. To draft and publish rules, if so instructed by the Commission, that shall come into force once approved and published by the Commission.

4. To keep records and monitor Registered Enterprises, so as to ensure compliance with the provisions of this Law.

5. To promote and attract Investment in Afghanistan through wide and multi-facet campaign.

6. To assist Investors in understanding this Law and rules, regulations and procedures related to Investors.

7. To provide necessary facilitation to Investors in applying for and in receiving Certificates of Registration

8. To monitor, supervise and administer the implementation of the provisions of this Law and other related rules, regulations and procedures.

Chapter Three

REGISTERED ENTERPRISES

Article 10: Approved Enterprises Registration

(1) An enterprise shall be considered an Approved Enterprise when it is recognized by the Commission or by the Office in accordance with Article 12 of this law. The Office shall be responsible to register the enterprise and keep its records and files.

(2) Registered Enterprises may be established by either: 
1. Business entities organized under Afghan law, or

2. Business entities organized under the laws of another nation, but registered to do business in Afghanistan in accordance with the laws of Afghanistan

(3) Registered Enterprises may have ownership in any of the following forms:

1. One hundred percent (100\%) ownership by Investors, or,

2. A joint venture between the Government of Afghanistan and other Investors.

Article 11: Applying for Recognition as a Registered Enterprise

(1) A Person that wishes to register an entity as a Registered Enterprise must submit to the Office an application giving information in substance and form as required by this Law and by rules, regulations and procedures promulgated by the Commission.

(2) A person may seek recognition as a Registered Enterprise for a business entity that is already in existence or an entity that will be formed.

Article 12: Recognition and Denial of Registered Enterprises

(1) Within a fixed time period to be specified in rules promulgated by the Commission, the Commission or the Office, as appropriate, shall make a decision regarding the recognition of an entity's application that meets the terms established by this Law and shall inform the applicant. (2) An application for registration can only be denied when the entity did not comply with this Law or regulations or rules issued. If the Commission or Office has denied an application, it shall give an explanation in writing for the denial.

(3) When the applicant corrects the application according to the provisions of part (2) of this article, the applicant may re-apply after correcting the situation that gave rise to the denial.

(4) If the Commission or Office has not sent the response described in Article 13(1) above within the fixed period described above, the entity shall be deemed recognized.

(5) If the Commission or Office has recognized an existing entity, the Office shall immediately register such entity as a Registered Enterprise and provide a certificate to the entity evidencing its status as a Registered Enterprise (the "Certificate of Registration").

(6) If the Commission or Office has recognized an entity that has not yet been formed, the Office shall register such unformed entity as a Registered Enterprise and provide a Certificate of Registration. Thereafter, the entity must be formed within a fixed time period established in rules promulgated by the Commission.

(7) An entity shall retain its status as a Registered Enterprise unless its registration is rescinded pursuant to Article 14 below.

Article 13: Reporting Submission

(1) A Registered Enterprise must immediately notify the Office if there has been a change in its ownership or capital structure, or if an Investor in the Registered Enterprise contributes additional capital.

(2) A Registered Enterprise shall annually file an update (the "Annual Update") with the Office. The Annual Update must be submitted to the Office within ninety (90) days of the end of the fiscal year of the Registered Enterprise and shall include an update of the information provided by the Registered Enterprise in its application pursuant to the terms of Article 11 above, along with such other information as the Commission or the Office, as the case may be, deems appropriate. 
Article 14: Loss of Registered Enterprise Status

(1) The Commission or, if so instructed by the Commission, the Office may review and revoke an entity's recognition as a Registered Enterprise.

(2) The Status of an Registered Enterprise shall be revoked under the following conditions:

1. The Registered Enterprise entity is dissolved.

2. The Registered Enterprise ceases to exist or operate as a viable concern.

3. The Registered Enterprise violates, in a substantial respect, applicable provisions of this Law.

(3) A Registered Enterprise shall be informed for its violation before an entity's status as a

Registered Enterprise is revoked, except for violations of Article 12(6) above.

(4) The Commission or the Office shall give three (3) months extension to the Approved Enterprise to remedy the situation and/or bring itself into compliance with this Law.

\section{Chapter Four}

RIGHTS AND RESPONSIBILITIES OF

REGISTERED ENTERPRISES AND OF FOREIGN INVESTORS

Article 15: Application of Afghan Law

Unless otherwise specifically provided by this Law or other Afghan laws, all Registered

Enterprises, and all investors, whether domestic or foreign, must abide by all applicable laws of Afghanistan.

Article 16: Right to be Free from Discriminatory Governmental Actions Unless otherwise specifically provided in this Law or other Afghan laws, the provisions of this Law and any other Afghan laws shall be applied equally and fairly to all similarly situated Registered Enterprises, whether they have foreign equity ownership or not, and to all similarlysituated Investors.

Article 17: Income Tax Concessions for Registered Enterprises

(1) A Registered Enterprise which incurs a net operating loss in any fiscal year may carry this loss forward and apply it as a deduction from its taxable income to the extent permitted in the Income Tax Law.

(2) A Registered Enterprise shall be entitled to an accelerated deduction for depreciation on Capital Assets to the extent permitted in the Income Tax Law.

Article 18: Import-Export Duty and Other Tax Concessions for Registered Enterprises A Registered Enterprise shall be exempted from export duties on products that it manufactures or assembles in Afghanistan to the extent permitted in the Customs Code. An export license shall be required for such exports but such license shall be granted automatically upon submission of such documentation as is required by law.

Article 19: Access to Banking

(1) A Registered Enterprise shall have the right to use banking facilities in Afghanistan as follows:

1. To open accounts in foreign currency and to use these banks, among others, to receive loans and credit in foreign currency from outside Afghanistan to advance its legitimate business. 
2. To open bank accounts in foreign currency outside of Afghanistan for the purpose of purchasing equipment and machinery, raw materials, spare parts, feedstock and for services used by the Registered Enterprise in conducting its operations, and for payment of salaries and benefits to expatriate employees, and for all other purposes of the Registered Enterprise that are not contrary to Afghan laws.

Article 20: Labor and Employment

(1) A Registered Enterprise shall have the right, directly or indirectly, to employ foreign managerial and expert personnel of any nationality notwithstanding any provision to the contrary in Afghan laws. .

(2) A Registered Enterprise shall have the right to enter into service contracts with foreign Persons in order to conduct its business activities. In this case, the work permits for such foreign personnel shall be granted according to the laws applicable in Afghanistan.

(3) Registered Enterprises, domestic or foreign, in which Foreign Investors have equity ownership, are encouraged to hire Afghan personnel whenever possible in order to further their technical development.

Article 21: Land Use by Registered Enterprises

A Registered Enterprise shall have the right to lease land in order to carry its operations and shall not be barred from leasing real property for terms up to fifty (50) years, in accordance with Afghan law.

Chapter Five

TRANSFER OF CAPITAL AND PROFITS ASSOCIAT ED WITH FOREIGN INVESTMENT

Article 22: Transfer of Foreign Investment Capital

(1) A Foreign Investor shall be permitted to freely transfer out of Afghanistan without unreasonable delay distributions received from a Registered Enterprise in whatever foreign currency the Foreign Investor chooses, at the prevailing exchange rate for that currency.

(2) A Foreign Registered Enterprise may transfer pursuant to this provision funds in an aggregate amount equal to the amount of such Foreign Investor's registered Foreign Investment, and it may take place in one or more transactions

(3) A Foreign Registered Enterprise must notify the Central Bank (or such other entity designated by the Law) of such transfer. The Central Bank or other entity, as the case may be, shall reduce the amount of such Foreign Investor's registered Foreign Investment by the amount that has been transferred.

Article 23: Transfer of Profits Associated with Foreign Investment

A Foreign Investor shall be permitted to freely transfer outside of Afghanistan without unreasonable delay dividends, or distributions treated as dividends under the Income Tax Law, received from a Registered Enterprise in whatever foreign currency the Foreign Investor chooses after satisfying his(her) financial obligations, at the prevailing exchange rate for that currency.

Article 24: Transfer of Principal and Other Payments of Foreign Loans 
A Registered Enterprise shall be permitted to freely transfer out of Afghanistan funds for payment of principal, interest and fees relating to a Foreign Loan to such Registered Enterprise in the currency of the Foreign Loan after satisfying his(her) financial obligations at the prevailing exchange rate..

Chapter Six

SALE OF REGISTERED ENTERPRISES; TRANSFER OF PROCEEDS

Article 25: Sale of Registered Enterprises

(1) Foreign Investors shall have the right to sell or transfer all or a part of its ownership interest in a Registered Enterprise to any Person or to the Government of Afghanistan without the permission of the Commission or the Office only if the seller has not violated any limitations on Investment established pursuant to Afghan law.

(2) The Commission shall have the right to void any sale made in violation of this provision.

(3) The Investor shall notify the Office of any sale or transfer of an ownership interest in a

Registered Enterprise and the purchaser shall be recorded as a Foreign Investor or domestic Investor as the case may be.

Article 26: Transfer of Proceeds from the Sale of Registered Enterprises

A Foreign Investor shall have the right to transfer out of Afghanistan the proceeds of any such sale in the currency of the Investment at the prevailing exchange rate after satisfying his (her) legal and financial obligations.

Chapter Seven

EXPROPRIATION

Article 27: Expropriation

The State can expropriate an Investment or the assets of a Registered Enterprise only for the purpose of public interest, based on a law permitting such expropriation, and on a nondiscriminatory basis.

Article 28: Compensation for Expropriation

The State shall provide prompt, adequate and effective compensation in conformity with principles of international law, equivalent to the fair market-value of the expropriated Investment or assets immediately before the expropriating action was taken. Such compensation shall include interest at the one-year LIBOR rate for the period between the date of the expropriation or nationalization and the date of complete payment of the compensation. In the case of an Investment made in a foreign currency, the compensation shall be made in the currency in which the Investment was made at the prevailing rate of exchange.

Article 29: Transfer of Compensation for Expropriation \& Appeal

(1) If in an expropriated property the percent of ownership interest held by Foreign Investor(s) exceeds over twenty five percent (25\%), such Foreign Investor(s) or Registered Enterprise, as the case may be, shall have the right to dispute the expropriation or the adequacy or fairness of the compensation therefore pursuant to the provisions of Article 29 below. 
(2) A Foreign Investor or a Registered Enterprise of which over twenty five percent $(25 \%)$ of the ownership interest is held by Foreign Investors may freely transfer any payment from the Government as compensation for expropriation or nationalization out of Afghanistan without the payment of taxes to the extent that such exemption is permitted by the Income Tax Law.

Chapter Eight

DISPUTE RESOLUTION

Article 30: Dispute Resolution

(1) Disputes shall be resolved according to the provisions of this Law.

(2) An Investor or a Registered Enterprise may, in any contract or other agreement, specify the following:

1. Any arbitration or other dispute resolution procedure,

2. That the place of such arbitration may be outside of Afghanistan,

3. That the law of a jurisdiction other than Afghanistan may apply to the resolution of such dispute.

(3) If such contract or other agreement so provides, any award resulting from such arbitration or other dispute resolution procedure shall be final, and shall be enforceable by the Government upon application of any party to such arbitration or procedure.

(4) Except as otherwise provided in section 5 of this Article 29, if a dispute arises pursuant to a contract or other agreement entered into between an Investor or a Registered Enterprise on the one hand and the State (or any constituent subdivision, agency or instrumentality thereof) on the other, with regard to an Investment, or if an Investor or Registered Enterprise has a claim under Chapter 7 of this Law, the dispute shall be resolved according to applicable Afghan law.

(5) If a dispute arises pursuant to a contract or other agreement entered into between a Foreign Investor or a Registered Enterprise with foreign equity ownership and the State or any constituent subdivision, agency or instrumentality thereof in regard to a Foreign Investment, or if a Foreign Investor or Registered Enterprise has a claim under Chapter 7 of this Law, the parties shall endeavor to settle such dispute amicably by mutual discussions. Failing such amicable settlement, and unless the parties to such dispute otherwise agree, the parties shall submit such dispute either (i) to the International Centre for Settlement of Investment Disputes ("ICSID") for settlement by arbitration pursuant to the Convention on the Settlement of Investment Disputes between States and Nationals of Other States of March 18, 1965, as such may have been or may be amended from time to time (the "Convention") or (ii) if ICSID rules preclude the Foreign Investor from arbitrating before ICSID or if the Foreign Investor otherwise prefers, to arbitration in accordance with UNCITRAL Rules.

The Government, by operation of this Article 29(5), consents to the submission of any such dispute to ICSID for settlement by arbitration in accordance with Article 25(1) of the Convention. For the purpose of Article 25(2)(b) of the Convention, a Registered Enterprise incorporated under Afghan laws or otherwise registered to do business in Afghanistan of which over twenty five percent (25\%) of the ownership interest is owned by a Foreign Investor shall be treated as a national of a state other than Afghanistan. For the purpose of Article 25(3) of the Convention, if one of the disputing parties is a constituent subdivision, agency or instrumentality of the State, the Government, by operation of this Article 29(5), gives its consent to the submission of such dispute to ICSID for settlement by arbitration and no further consent of the State is required for the submission of such dispute to ICSID. 
Chapter Nine

MISCELLANEOUS

Article 31: Preference

In case of any discrepancy between provisions of this Law and any provisions of existing laws relating to or affecting private Investment, the provisions of this Law shall prevail.

Article 32: Transition

(1) Pursuant to the provisions of Article 31 below, except to the extent specifically otherwise provided in the Income Tax Law, the Law on Domestic and Foreign Private Investment in Afghanistan (Official Gazette number 803, dated 20 Sunbulla 1382 (20 September 2002)) ("the Prior Investment Law") will become null and void upon execution of this Law.

(2) To comply with this Law, an entity that is registered as an Approved Enterprise under the Prior Investment Law is required to re-register with the Office in accordance with Articles 12 and 13 above, and such rules as are issued by the Commission and made publicly available, within six (6) months from the date of execution of this Law or such longer period as may be established in rules issued by the Commission.

(3) Except to the extent specifically otherwise provided in the Income Tax Law, upon such reregistration each investor and each Approved Enterprise, in its new capacity as a Registered Enterprise, will be fully subject to, and may avail itself of, the provisions of this Law. Any investor or Approved Enterprise which fails to re-register in accordance with Article 30(2) above shall be ineligible to avail itself of any of the rights or privileges accorded under this Law.

Article 33: Execution; Abrogation of Previous Legislation

This Law shall be effective upon its execution by the President of the Islamic State of Afghanistan and shall be published in the Official Gazette and upon the execution of this Law, the Law on Domestic and Foreign Private Investment in Afghanistan (Official Gazette number 803 , dated 20 Sunballa 1382) shall become null and void. 


\section{INTERIM CRIMINAL CODE FOR COURTS}

\section{Chapter 1 General Provisions}

Article $1 \quad$ Applicable Rules

Three judges shall be assigned to every primary court. One of them as President of the Court. In places where the said team cannot be deployed because of lack of availability or security reasons, one judge shall be assigned thereto, functioning as a monocratic court. The decision to deploy one judge to a district as a monocratic court is made by the President of the Provincial Court.

Article 2 Record of Procedural Activities

1. All the activities accomplished in execution of the provisions of this code shall be recorded in written form by a public officer.

a. The judicial police activities shall be recorded by a police officer taking part in the operations.

b. The Saranwal activities shall be recorded by a secretary of the office.

c. The activities of the judges shall be recorded by a clerk.

2. The activities which are mentioned in paragraph 1 of this article include a full text or a terse compilation of the statements of the suspect, accused, victim, expert and witness as well as the description of the expert's activities and the running of the hearings.

3. The records of the statements of the suspect, accused, victim and witness shall be undersigned by them or when the person is unable to do so signed by finger prints.

4. In case the latter refuse or are unable to sign, the public officer responsible for the recording shall mention the circumstances.

5. The above mentioned records constitute official documents.

The lack of recording, apart possible disciplinary actions against the responsible of the omission brings about the legal inexistence of the related activities.

\section{Article $3 \quad$ Terms}

1. The procedural terms are indicated by hours or days.

2. When a term established by days expires on a holiday it is extended to the following working day.

3. In the calculation of the duration of the term the hour or the day of commencement shall not be included.

4. The final day term for filing a document or accomplishing any procedural activity expires at the hour of closure of business of the related office as established by the home rules.

Article 4 Presumption of Innocence

From the moment of the introduction of the penal action until when the criminal responsibility has been assessed by a final decision the person is presumed innocent. Therefore decisions involving deprivations or limitations of human rights must be strictly confined to the need of collecting evidence and establishing the truth. 


\section{Article $5 \quad$ Suspect and Accused}

1. A person is considered a suspect when in any deed of the investigations the commission of a crime is attributed to him.

2. A person is considered an accused when an act of indictment has been enacted by the Saranwal according to paragraph 4 of article 39 .

3. The quality of accused remains until when the person is discharged or sentenced by a final decision.

4. The suspect and the accused shall not undergo intimidations or any form of physical or psychological pressure.

5. Their statements shall be made in a condition of absolute moral freedom.

6. The suspect and the accused have the right to abstain from making any statement even when they are questioned by the relevant police or judicial authorities.

7. The police, the Saranwal and the Court are duty bound to clearly inform the suspect and the accused before interrogation and at the time of arrest about his or her right to remain silent, right to representation at all times by defense counsel, and right to be present during searches, lineups, expert examinations and trial.

8. The words or terms "suspect" and "accused" also include in their definition his/her defense counsel.

Article 6 Duration of Provisional Arrest

1. The terms for the duration of provisional detention following the arrest during the investigative phase are those established in article 36 .

2. During the trial at the Primary level, the Court can extend the detention for two additional months; during the trial at the appeal level the Court can extend the detention for another two months term; during the trial before the Supreme Court the detention can be further extended by the same Court for additional five months.

3. Whether during the celebration of the above mentioned trials the related terms expire, the arrested person shall be released.

Article $7 \quad$ Exclusionary Rule

1. The evidence which has been collected without respect of the legal requirements indicated in the law is considered invalid and the Court cannot base its judgment on it.

\section{Article $8 \quad$ Final Decision}

1. The decision of the Primary Court is final if a valid appeal has not been filed within the term prescribed by the law.

2. The decision of the Court of Appeal is final if recourse to the Supreme Court has not been filed within the term prescribed by the law.

3. The decision of the Supreme Court is final.

4. The Saranwal at the Primary Court shall give execution to the final decisions. To this end the Court of Appeal and the Supreme Court shall deliver to the Saranwal at the Primary Court that 
adopted the initial decision the file containing the procedural documents and the objects confiscated.

\section{Article 9 Denunciation of Forgery}

1. In every phase of the proceeding, the suspect, the accused and the victim can denounce the forgery of a document considered among the evidence material.

2. The denunciation is submitted to the Primary Saranwal during the investigations and to the Court in the successive phases and degrees.

3. The Saranwal is also entitled to make the denunciation of forgery to the Court.

4. If the investigating Primary Saranwal or the Court deems the denunciation grounded the procedure is stayed. In this case the same Saranwal during the investigation phase or the competent Saranwal to whom the document shall be transmitted introduces the penal action for forgery.

5. The proceedings are resumed when the issue has been settled by a final decision.

6. Otherwise the proceedings are not discontinued and the document in question is delivered after the final decision to the Primary Saranwal for the adoption of the decisions belonging to his competence.

7. In the decision that rejects the denunciation of forgery the suspect or accused that made the case can be sentenced according to provisions of law.

\section{Article $10 \quad$ Abstention and disqualification of the Saranwal}

1. The primary Saranwal is entitled to request his superior to make him abstaining from the investigations when he believes that there are grounded reasons to do so.

2. The suspect has the right to request the higher Saranwal to exonerate the primary Saranwal conducting the investigations against him, presenting the evidence of the occurrence of the grounded reasons indicated in pararagraph 1.

3. The superior Saranwal can decide to authorize the abstention of the Primary Saranwal or exonerate him accepting his request or responding to a complaint of the suspect when there are grounded reasons to do so.

4. When the superior Saranwal has authorized the abstention of the Primary Saranwal or has exonerated him, shall substitute the same.

\section{Article 11 Abstention of the Judge}

1. A judge cannot handle the case if:

a. the crime was committed against him or his relatives;

b. he has performed the duties of the judicial police, of the Saranwal or has given witness or functioned as an expert in the same case;

c. he has been defense counsel of the accused.

2. When the cases indicated in paragraph 1 occur, the judge of a single member court shall request the President of the Provincial Court to authorize him to abstain.

3. When the cases indicated in paragraph 1 occur to a judge member of a collegial court, then he or she shall request the President of the Court to authorize him or her to abstain. 
4. When the cases indicated in paragraph 1 occur to the President of a collegial court, he or she shall request the President of the next higher court to authorize him or her to abstain.

5. The President of the appropriate level Court either accepts or rejects the request. This decision cannot be protested.

6. When the President of the appropriate level Court authorizes the abstention, he or she shall substitute the requesting judge or President for the handling of the case.

7. Pending the decision, the criminal procedures shall be stayed.

Article 12 Disqualification of the Judge

1. The accused or the Saranwal can request the disqualification of a judge or a President when he/she thinks that one of the cases indicated in paragraph 1 of art. 11 occurs. The request shall be addressed according to the case to the appropriate President indicated in paragraph 2, 3 and 4 of art. 11. The president either accepts or rejects the request.

2. In case of acceptance, the President of the appropriate level Court shall substitute the disqualified judge or President. This decision cannot be protested.

5. Pending the decision, the criminal procedures shall be stayed.

\section{Article 13 Definition of Flagrante Delicto}

1. A crime is considered flagrante delicto in the moment in which is committed.

2. The perpetrator who is caught during the commission of crime is in a state of "flagrante delicto."

3. It is considered also in state of flagrante delicto the prepetrator when, upon the commission of the crime, is immediately pursued by the police, or the victim or other persons.

\section{Article $14 \quad$ Joinder and Severance of Cases}

1. The Primary Saranwal or the Court can join different cases when:

a. a suspect or an accused is alleged of having committed more than one crime;

b. different investigations or trials are conducted in relation to accomplishers in the same crime;

c. the same evidence is relevant for different crimes.

2. The primary Saranwal and the Court can sever joint cases when:

a. this contributes to a more expeditious handling of them;

b. adults and minors are accomplishers in the same crime.

\section{Article 15 Procedural Nullity and Consequences}

1. The criminal procedure is considered null and so declared, even ex officio, when:

a. The persons who have acted as judges or Saranwal did not posses the related legal status;

b. The procedure has not been instituted by the Saranwal and when he has not been present in cases in which his presence is mandatory.

Article 16 Procedural Invalidities and their Consequences 
1. All the violations of procedural provisions different from those indicated in the previous article bring about the invalidity of the procedure only if they are denounced by the interested party.

2. When the denunciation is made during the investigations or the trials the responsible judicial authority shall make decisions to redress the procedure whenever possible.

3. In any case the denunciation can be made in the appeal or in the recourse to the Supreme Court.

4. The Court of Appeal or the Supreme Court declares the invalidity of the procedure whenever it appears that the violations of procedural provisions have provoked relevant distortions in the decision of the case.

\section{Article 17 General Rules for Notifications}

1. The notifications are served by the judicial police that shall give the requesting judicial organs a report on the service rendered.

2. The notifications are served in the domicile of the concerned person in his hands or in the hands of an adult relative or cohabitant. Should this not be possible, a copy of the deed is left at his dwelling place.

3. When the person is under arrest the notification is served on him through the Director of the prison.

4. When it has not been possible to locate the domicile of the concerned person, the judicial police shall conduct accurate investigations aimed at identifying the places where the person lives or works. In case the search for finding these places proves fruitless, the notification deed shall be delivered to the administrative organ of the place considered as the person's last place of residence.

\section{Chapter 2 Common Provisions for the Suspect and the Accused}

Article 18 Defense Counsel

1. Legal assistance to the suspect and the accused requires the service of a qualified professional.

2. To this end an official register is established in the Ministry of Justice where only persons with a university degree in law or sharia can be included.

3. The suspect and the accused can be, in any case, assisted by a defense counsel of their choice.

\section{Article 19 Legal Aid}

1. The suspect or the accused be financially unable to appoint a defense attorney are entitled to have a free defense attorney appointed for him or her in the following manner:

a. The investigating Saranwal or the Court adjudicating the case, on the petition of the person, appoints a defense attorney for the destitute person from amongst the lawyers officially permitted to work as defense attorney.

b. The person for whom an attorney has been appointed reserves the right not to accept the appointed defense attorney and to defend himself in person. 
c. The fees of the aforesaid attorney shall be paid from the State budget and its extent shall be fixed by regulation.

Article 20 Interpreter

1. The suspect or the accused who does not know the language used during the investigations and the trials or who is deaf, dumb or deaf and dumb shall be given an interpreter for, at least, explaining to him the charge and the indictment and for assisting him during the interrogations and confrontations.

\section{Chapter 3 Reporting of Crimes and Role of the Saranwal}

\section{Article $21 \quad$ Reporting of Crimes}

1. Police are duty bound to report within 24 hours to the Primary Saranwal all the crimes they happen to know.

2. Public officers are duty bound to report crimes ascertained in the performance of their duties. 3. Private citizens are duty bound to report to the judicial police or the Primary Saranwal only crimes against internal and external security.

\section{Article 22 Institution of Proceedings}

1. The Primary Saranwal has the obligation to introduce the penal action for detection and prosecution of all crimes, known directly by him or reported to him, committed in the territory of the District, unless otherwise expressly provided by law.

2. The Saranwal shall not dismiss or stay a case except as otherwise provided by the law.

\section{Article 23 Investigations}

1. The Primary Saranwal performs the investigation activities by his own or making recourse to the collaboration of the judicial police.

2. The purpose of the criminal investigation is the establishment of the truth and in order to do so the Primary Saranwal shall extend his assessment to cover all facts and evidence relevant for establishing whether the crime has been committed and ascertaining who is responsible for it.

3. In conducting the investigations the Primary Saranwal is duty bound to evaluate incriminating and exonerating circumstances equally and to respect the interest of the victims.

\section{Article 24 Transfer of the Investigation}

1. When in the course of the investigations it appears that the competence belongs to another District the Primary Saranwal shall transfer the case to the latter.

2. The suspect who deems that the competence belongs to a different Primary Saranwal can submit to the investigating Primary Saranwal a request for transfer.

3. Should the Primary Saranwal refuse to transfer, the suspect can file a complaint to the higher Saranwal, whose decision cannot be protested. 


\section{Chapter 4 Jurisdiction of the Courts}

Article $25 \quad$ Jurisdiction on crimes

1. The District Courts are competent for adjudicating petty, misdemeanors and felony crimes according to the provisions of the law.

Article 26 Territorial Jurisdiction

1. The territorial jurisdiction is determined by the place where the crime is committed.

2. In case of attempt crime the competence belongs to the Court which has jurisdiction on the place where the last action for the commission of the crime has been accomplished.

3. In case of continuing or permanent crime the competence belongs to the Court having jurisdiction on the place where the continuation or the permanence ceased.

4. When an accused is to be adjudicated for more than one crime, the territorial competence belongs to the Court having jurisdiction in the venue where the most serious crime has been committed.

5. When the Court realizes that in cases of multiple crimes committed by the accused the most serious crime has been committed in another venue, it shall transfer the procedure to the court having jurisdiction in that venue.

\section{Article 27 Conflict Between Two Courts}

1. When between two District Courts located in the same Province raises a conflict on the attribution of territorial jurisdiction, the case is ruled by the President of the Provincial Court.

2. When the said conflict raises between Courts in different Provinces, the case is ruled by the Supreme Court.

3. The settlement of the territorial jurisdiction conflict is made at the request of one of the conflicting Courts or of the related Saranwal.

4. The decision settling the conflict is notified to the competent Court.

\section{Chapter 5 Duties and Jurisdiction of Judicial Police}

Article 28 Categories of Judicial Police Officers

1. Judicial police are categorized as follows:

a. the Judicial police's commissioned officers are the superior ranks of the State police;

b. the ordinary officers of the judicial police are the low ranks of the State police.

2. Special laws can attribute the functions of judicial police to other public officers.

Article 29 Role of Judicial Police

1. The judicial police perform their duties under the direction and supervision of the Saranwal.

2. The judicial police have the role of detecting crimes, collecting evidence, and seeking suspects in the pursuit of justice. 
Article $30 \quad$ Judicial Police's Arrest

1. The judicial police shall arrest on their own initiative:

a. the offender who is caught in state of flagrante delicto of misdemeanors, punished by medium term imprisonment, or felony;

b. the person who is allegedly the author of a felony and there is risk of his disappearance.

2. In all other circumstances, the judicial police perform arrests only in execution of orders of the judicial authorities.

\section{Article $31 \quad$ Judicial Police's Interrogation}

1. The judicial police, after having identified the person arrested on their own initiative, inform him of the reasons of the arrest and interrogate the same about the crime and its circumstances within a maximum of twenty-four hours.

2. Immediately after a report shall be sent to the Primary Saranwal and the person shall be put at his disposal.

\section{Article 32 Judicial Police's Urgent Activities}

1. In case of flagrante delicto and whenever there are grounded reasons to believe that urgent action is needed to preserve the evidence the judicial police can, on their own initiative, conduct preliminary investigations which include:

a. personal frisks or searches of premises and other places;

b. seizure of objects and documents;

c. inspection of persons and places, taking photos;

d. requesting the assistance of experts for performing activities which require special professional qualification.

2. Immediately after having performed the above listed activities, the judicial police shall send a report to the Primary Saranwal.

3. Defense Counsel of suspect and accused has the right to be present in investigation and interrogation phases according to art. 38 of this code.

\section{Chapter 6 Investigation Performed by the Saranwal}

Article 33 Ratification of the Police's Decisions

1. The Primary Saranwal immediately after having been informed about the judicial police's activities indicated in articles 30,31 and 32 either sanctions the deeds of the judicial police's activities or adopts decisions to revoke or modify them.

2. Before taking the actions mentioned in the previous paragraph the Saranwal can ask the police to provide explanations.

Article 34 Interrogation of the Person Arrested

1. The Primary Saranwal shall interrogate the person arrested within forty-eight hours from the moment when the person has been put at his disposal. 
2. The Primary Saranwal can release the arrested suspect whenever he deems no more necessary the deprivation of liberty.

\section{Article 35 Arrest and Seizures by the Primary Saranwal}

1. In the course of the investigations activities the Primary Saranwal can order the arrest of the alleged author of a misdemeanor punishable by medium term imprisonment or felony and seizure of items and goods connected with the crime.

2. The person arrested shall be interrogated within forty-eight hours.

Article 36 Terms for Indictment in Case of Arrest

When the arrest performed by the Judicial Police is sanctioned or when the arrest has been ordered by the Saranwal and it remains in force, the arrested person shall be released if the Saranwal has not presented the indictment to the Court within fifteen days from the moment of the arrest except when the Court, at the timely request of the Saranwal, has authorized the extension of the term for not more than fifteen additional days.

\section{Article 37 Collection of Evidence}

1. During the investigations phase the Primary Saranwal shall collect all relevant evidence which can substantiate a decision pros or cons the suspect.

2. The collection of evidence is not restricted to particular forms or matters. The Primary Saranwal is free in selecting tools and modalities of proof.

3. The following shall be considered as key tools:

a. Witnesses

b. Confrontations

c. Line up procedures

d. Inspections

e. Searches

f. Seizure

g. Expert exams and evaluations

h. Interrogations

Article 38 Defense Counsel Presence

1. The defense counsel has the right to be present at all times during the interrogation of the suspect.

2. The suspect and the defense counsel have the right to be present during searches, confrontations, line-up procedures and expert examinations as well as during the trial.

3. In the investigation phase the Saranwal and the judicial police shall notify the suspect and his defense counsel of searches, confrontations, line-up procedures and expert examinations in order to allow them to be present. This duty can be waived only when there is an urgent need to conduct the said operations, which is defined as when it is a flagrante delicto crime or there is a fear of the loss of evidential facts. 
Article 39 Conclusion of the Investigation

1. At the conclusion of the investigations phase, if the Primary Saranwal deems that there is not grounded evidence dismisses the case.

2. The victim or higher Saranwal can file a complaint to the Court against this decision within ten days.

3. The Court, after having examined the case, can confirm the decision of the Saranwal or vice versa request him to lodge the indictment.

4. In any other case the Saranwal shall submit to the Court the act of indictment requesting the assessment by trial of the criminal responsibility of the indicted person.

5. The act of indictment is comprised of the following:

a. Complete identification of the suspect;

b. Complete description of the crime.

6. Together with the act of indictment the Primary Saranwal shall transmit to the Court the file containing all the deeds formed during the investigations, putting at the Court's disposal the seized items and goods.

\section{Chapter 7 Notification of the Deeds and Representation During the Investigations}

Article $40 \quad$ Notification on the suspect

1. During the investigations the judicial police and the Saranwal shall give notifications of the deeds to the suspect, to his defense counsel and the victim of the activities to be accomplished, to which they have the right to be present.

2. If there are no particular grounded reasons of urgency, the notification should be served at least three days before the performance of the activity.

3. Reasons of urgency imposing a shorter period or absence of notifications shall be clearly mentioned in the record of the activities.

Article 41 Notification on the Not Found Suspect and his Representation

1. When it has not been possible to identify any of the places indicated in article 17 , the notifications shall be served on a defense counsel appointed by the police during their autonomous investigations, or by the Saranwal during his investigations.

2. The appointment of the defense counsel is made by the police and the Saranwal in a written form.

3. In this case the defense counsel represents the suspect.

4. The above indicated decision ceases to take effect at the end of the investigations.

\section{Chapter 8 The Trial}

Article 42 Preparation of the Trial

1. The Court immediately after having received the act of indictment, orders the notification of the deed indicating the day and hour fixed for the commencement of the trial. 
2. The deed shall contain the name of the accused and the indication of the alleged crime with its factual circumstances in reference to the related law provisions and shall be served on the accused and his defense counsel, the victim and the Saranwal at least five days in advance.

Article 43 Access of the Accused to the Findings of the Investigation

1. The accused and his defense counsel are entitled to examine the documents contained in the file mentioned in the last paragraph of article 39 and the objects under seizure.

Article $44 \quad$ Mental Insane Accused

1. If during the trial it appears that the accused suffers of a mental illness which prevents him from the possibility of defense, the Court either ex officio or at the request of the Primary Saranwal stays the proceeding submitting the accused to mental examination.

2. Should examination confirm the above indicated mental state, the resumption of the proceedings is postponed until the suspect recovers.

3. In case the accused is later on sentenced to imprisonment, the time spent in a close institution for the mental examination is detracted from the prison term.

Article 45 Accused's Obligation to Appear

1. The accused, either under detention or at liberty, shall be obliged to appear before the court when confrontations or experiments involving his physical presence are scheduled.

2. The accused at liberty refusing to appear in the instances indicated in the previous paragraph shall be accompanied by the police.

Article 46 Trial in Absence of the Not Found Accused

1. When it has not been possible to serve the notifications on the accused in any of the forms provided for in article 17, because none of the places there indicated are known, the Court shall issue a decree stating that the accused cannot be found, appointing a defense counsel for him.

2. Later on the notifications shall be served on the defense counsel.

3. Notifications made in this way are valid to all intents and purposes. The accused that cannot be found is represented by the defense counsel.

4. The decree indicated in the first paragraph ceases to take effect at the end of the degree in which has been issued and shall be re-issued in each of the following degrees.

5. Every decree must be preceded by a new search in the places indicated in article 17.

Article 47 Trial in Absence of the Summoned Accused

1. When the notification indicated in article 42 has been delivered to the accused and he does not appear, the judge appoints a defense counsel for him.

2. Notifications continue to be served on the accused following the provisions of article 17.

Article 48 Hearings in Progress 
1. When the trial requires more than one hearing, the Court fixes the date and hour of the successive hearing, giving verbal notice to the accused, the defense counsel and the other persons who have to appear.

\section{Article 49 Attendance of Witnesses and Experts}

1. Witnesses and experts are duty bound to be present in the hearing indicated in the notification served on them.

2. If they do not appear without grounded justifications the Court orders their accompaniment by the police imposing on them a fine up to 500 Afghani.

\section{Article $50 \quad$ Oaths}

1. Witnesses who have completed fourteen years of age are duty bound to swear, before giving evidence in Allah's name to tell the truth and be honest in their testimony.

2. If the witness has used the term "Ash-ha-do" knowing that the term itself implies taking an oath, he or she is not required to swear in that terms. However, it is permissible for information gathering to hear the testimony of a witness under fourteen years of age without making him take the oath of truthfulness.

\section{Article $51 \quad$ Admission of Witnesses and Experts}

1. The Primary Saranwal submits to the Court the list of the witnesses and experts he wants to be heard together with the act of indictment, indicating the reasons of the relevance of their testimony and exams.

2. The accused and/or his defense counsel have the right to present their own lists of witnesses and experts indicating the reasons of the relevance of their testimony and exams.

3. The Court can exclude those witnesses or experts that in its view do not appear material for the adjudication of the case.

4. The Court, on its own initiative, can order the appearance of witnesses or experts who are not included in the above mentioned lists.

\section{Article 52 Order of the Hearing}

1. The order of the hearing is explained to the persons present by the Head of the Court.

2. The court keeps the order of the hearing. Hearings are open to the public except when the court decides that all or part of it shall be run without the presence of the public for reasons of morality, family confidentiality or public order.

3. The Primary Saranwal, the accused and his defense counsel have the right to be always present.

4. The accused that with his behavior disrupts the proceedings can be excluded by the Court for part or all the duration of the hearing. He is anyhow readmitted in the room when the verdict is read out.

Article 53 Conduct of the Hearing 
1. The Primary Saranwal is duty bound to take part in the hearing.

2. The accused and his defense counsel have the right to be present.

3. The Court proceedings are conducted according to the following order:

a. At the opening of the hearing the Court reads out the act of indictment;

b. When the accused is under detention the Court shall immediately assess the legality of the arrest and order the liberation of the accused when realizes that the arrest was unlawful or not necessary;

c. The Primary Saranwal makes an oral presentation of the case and of the findings of the investigations;

d. The judicial police officers who have conducted the investigations make oral reports of the activities accomplished;

e. The first witness to be heard is the victim;

f. Then the other witnesses and the experts are heard;

g. The accused can testify if he does not avail himself of the right to remain silent and the accused or his defense counsel can ask questions to the witnesses and the experts;

h. In case the witness cannot be present for health reasons the Court can hear him in his domicile;

i. The primary Saranwal and the defense lawyer can ask question to the accused.

4. The Court can, at any time, address questions to the accused, to any witness in the hearing and order confrontations.

5. The accused can refuse to answer the questions of the Court consistent with his right to remain silent.

\section{Article 54 Exemption from Testimony}

1. Spouses have the right not to give evidence against each other, even though their marital relation be ended.

2. The accused's ancestors and descendants and their relatives of second degree have the right to avoid testifying against one another except when:

a. the charge legally attributed to the accused is not committed against the witness himself; or

b. they reported the criminal offense.

\section{Article 55 Evidentiary Value of Investigative Activities}

1. The records of the testimonies of the witnesses as well as of the expert exams, collected during the investigative phase, can have the value of evidence as basis for the decision only if it results that the accused and/or his defense counsel were present during the operations and were in a position to raise questions and make objections.

2. Otherwise the related deeds have the sole value of clues.

\section{Article 56 Concurrent Crimes and Circumstances}

If from the deeds of the investigations or during the trial it results that there are alleged additional crimes and/or facts contributing as aggravating circumstances which have not been included in the act of indictment the Court, at the request of the Primary Saranwal, makes the 
related accusation to the accused and/or to his defense counsel, when present, giving them adequate time to prepare the defense.

\section{Article 57 Different Definition of the Crime}

When the Court deems that the crime is to be given a different definition from that indicated in the act of indictment on the basis of the same facts and circumstances included in the accusation shall grant the accused and the defense counsel a time allowance for presenting a defense vis-àvis the change in the definition.

\section{Article 58 Conclusion of the Trial}

1. At the conclusion of the operations indicated in the previous articles, the Primary Saranwal expresses his opinion requesting the Court to make a decision of dismissal or sentence, indicating the kind and the amount of punishment he deems adequate.

2. The accused or the defense counsel, when present, submits to the Court arguments in rebuttal of the accusation.

\section{Article 59 Decision of the Court}

1. At the completion of the activities, the Court declares the closing of the hearing and leaves the trial room for writing down 'in chamber' the decision of the case.

2. Later on, the Court enters the trial room again and reads out the verdict together with its reasons. This reading has the value of notification. If the reasons of the verdict are not read out by the Court in the same context, they shall be deposited in the office of the secretary of the Court within fifteen days from the moment of the decision.

3. The Primary Saranwal, the accused and his defense counsel shall receive notification of the deposit indicated in paragraph 2 of this article.

4. The accused tried in absentia, in the case of article 47 , shall receive notification of the decision read out by the Court together with the reasons deposited later on in the office of the secretary of the Court.

5. The notification indicated in the previous paragraph is served on the defense counsel of the accused in the case of article 46.

Article 60 Order of Arrest in the Decision

1. When the Court decides to impose a sentence of more than three years of imprisonment in the same decision can include an order of arrest.

Article 61 Requirements of the Decision

1. The decision shall contain:

a. The identification of the accused;

b. The description of the facts and of the circumstances included in the accusation;

c. A terse exposition of the reasons of the same decision with reference to facts and law provisions; 
d. The verdict

Article 62 Payment of Expenses of the Procedure

1. In imposing the sentence, the Court shall also order that the sentenced person pays the expenses incurred during the procedure.

2. If the related amount cannot be specified in that moment the order shall be given in generic terms mandating the administrative office to make the calculation.

\section{Chapter 9 Appeal Procedure}

Article 63 Appeal against the Decision of the Primary Court

1. The person who has been sentenced or the Primary Saranwal can contest the decision of the Court by filing an appeal.

2. The competent Court of Appeal is the Provincial Court.

3. The act of appeal shall be deposited with the secretary of the Court, which has made the decision, or with the secretary of the competent Court of Appeal within twenty days from the moments in which:

a. The Court has read out in the Court room, in the same context, the verdict and its reasons at the conclusion of a trial in which the accused and/or his defense council were present;

b. The reasons of the verdict, which were not read out together with the verdict, have been notified to the accused and to the defense counsel; in this case the second notification is considered the beginning of the term;

c. The accused tried in absentia has received the notification of the decision.

4. When in the same decision more than one person has been sentenced the last notification is considered the beginning of the term for all sentenced.

Article 64 Stay of the Procedure and Appeal of the decision in case of the not found accused

1. After the decision of the court in case of the not found accused the procedure stays until when the accused personally or the defense counsel delegated by him/her lays down an appeal.

2. In this case the beginning of the appeal term starts for the accused from the moment in which the same has been found and also a notification according to article 17 has been delivered to him/her.

3. The beginning of the appeal term starts for the Saranwal from the moment in which the Court notifies him about the notification delivered to the accused.

4. If the accused and the Saranwal do not lay down an appeal during the said term the decision becomes final.

Article 65 Modalities of the Appeal

1. The act of appeal shall be signed by the accused or by his defense counsel when the latter has represented the accused during the trial or by the Primary Saranwal.

2. The secretary of the Court receiving the act of appeal has to register it specifying the date and hour of the delivery. 
3. If the accused who wants to file the appeal and delivers a written text is unable to sign it because illiterate or for any other reason he/she can fingerprint it and the secretary of the Court shall certify this in the register.

4. If an illiterate person wants to file an appeal but is not in a position to present a written text, the secretary of the Court shall write down in the register his verbal statements.

Article 66 Content of Appeal

1. The act of appeal shall contain the indication of the contested decision and expose the reasons according to which the decision is considered wrong.

2. The denunciation of the errors of the decision shall make reference to:

a. Wrong application of the law and definition of crime;

b. Wrong evaluation of facts and circumstances;

c. Wrong application of the penalty and/or of its amount.

Article 67 Introductory Activities to the Appeal Trial

1. When the act of appeal has been deposited with the secretary of the Court which has made the contested decision, he shall immediately transmit to the Provincial Court the act of appeal deposited with him, and a copy of the related annotations on the register.

2. In the same time he shall forward to the Provincial Court the file containing all documents produced in the previous procedural phases, and the objects and documents seized.

3. When the act of appeal has been deposited with the secretary of the competent court of appeal, the President of the Provincial Court shall request the secretary of the court, which has made the contested decision to transmit the file containing the documents produced in the previous procedural phases, the objects and documents seized.

4. The President of the Provincial Court, upon reception of the above indicated material, shall fix the date and hour of the hearing for discussing the appeal and shall order the police to notify to the appealer and the Provincial Saranwal his decision. Similar notification shall be made to the appealing Primary Saranwal and to the adjudicated person in case the appeal was filed by the Primary Saranwal.

5. The notification shall be served to the accused, the adjudicated person and the primary Saranwal at least five days before the date of the hearing.

6. The Provincial Saranwal, the accused, the adjudicated person and defense counsels have the right to consult the documents and to vision the seized material.

\section{Article 68 Powers of the Court of Appeal}

1. The Court of Appeal shall confine its review to the points of the decision to which the act of appeal makes reference.

2. When the Appeal is filed by the primary Saranwal the Court can:

a. impose punishment in the case the accused was found not guilty in the Primary Court;

b. increase the punishment in the case the decision was founded on an error in the interpretation or application of the law.

3. When the appeal is filed only by the accused the Court can in no case increase the punishment inflicted by the Primary Court. 
Article 69 Appeal Hearing

1. Whether the Court of Appeal deems that the activities accomplished in the previous procedure are not sufficient for making a sound decision, it can hear the witnesses and experts already appeared in the Primary Court and collect new documents and explore new proofs.

2. Otherwise the Court makes its decision on the basis of the existing material and of the arguments presented during this discussion.

Article 70 Decision of the Court of Appeal

1. The appeal is rejected if it has not been filed within the established term.

2. The decision of the Court of Appeal can confirm or modify in all or in part the previous decision.

3. In the verdict the Court can order the arrest of the accused or release the accused under arrest.

4. The provisions of article 59 are applicable.

\section{Chapter 10 Recourse to the Supreme Court}

Article 71 Recourse against the Decision of the Court of Appeal

1. The person sentenced by the Court of Appeal, the victim or the Saranwal can lodge a recourse to the Supreme Court only if the complaint refers to:

a. Violations in the application of the law or wrong interpretation of the law; and

b. A decision based on the provisions of article 7 .

Article 72 Terms of the Recourse

1. The act of recourse shall be deposited with the secretary of the Court of Appeal which has made the decision or with the secretary of the competent collegium of the Supreme Court within thirty days from the moments indicated in paragraph 3 of article 63 .

Article 73 Modalities of the Recourse

1. For the modalities of the act of recourse the provisions of article 65 are applicable.

Article 74 Introductory Activities to the Supreme Court Trial

1. When the act of recourse has been deposited with the secretary of the Court of Appeal, this shall immediately transmit to the Supreme Court the act of recourse deposited with him and a copy of the related annotations on the register.

2. In the same time he shall forward to the Supreme Court the file containing all documents produced in the previous procedural phases, the objects and documents seized.

3. When the act of recourse has been deposited with the secretary of the competent collegium of the Supreme Court this shall request the secretary of the Court of Appeal, which has made the 
contested decision to transmit the file containing all documents produced in the previous procedural phases, the objects and documents seized.

4. The competent collegium of the Supreme Court, upon reception of the above indicated material shall fix the date and the hour of the hearing for discussing the recourse and shall order the police to notify to the accused claimant and to the Saranwal his decision. Similar notification shall be made to the claimant Saranwal and to the adjudicated person when the recourse has been filed by the Saranwal.

5. The notification shall be served to the accused, the adjudicated person and the Saranwal at least five days before the date of the hearing.

6. The accused, the adjudicated person, defense counsels and the Saranwal have the right to consult the documents and to vision the seized material.

\section{Article 75 Supreme Court Hearing}

1. At the opening of the hearing a judge of the collegium of Supreme Court makes an oral exposition of the case indicating the points of the Court of Appeal's decision which are in question and the reasons of the complaint.

2. Then the party which has filed the recourse makes an oral presentation of the recourse with comments on the alleged errors or violation of the law.

3. Thirdly, the other party takes the floor presenting arguments in support of the appeal decision.

4. During the discussion the President and the members of the Court can address question in order to receive clarifications on given issues. At the end of the discussion the Court leaves the trial room and takes its decision in Chamber. Later on the Court enters the trial room and the President reads out the adopted verdict.

5. The Court can read out the reasons of the decisions in the same context, or otherwise, deposit them with the secretariat later on.

\section{Article 76 Reject of the Recourse}

1. The Supreme Court rejects the recourse and confirms the decision when:

a. It has not been lodged within the established term;

b. The complaint does not concern one of the issues indicated in article 71;

c. It results that the complaint is not grounded.

\section{Article 77 Amendment of the Protested Decision}

1. Wrong interpretations of the law or wrong references to law provisions contained in the reasons of the verdict of the Court of Appeal do not bring about the annulment of the protested decision if they have not had a decisive influence on the verdict. In this case, the Supreme Court makes the amendments on its own and informs the Court which made the protested decisions about the errors.

2. When in the protested decisions must be corrected only the kind or the amount of the punishment, because they were wrongly indicated or calculated, the correction is made directly by the Supreme Court.

3. The Supreme Court amends directly the protested decision when law provisions more favorable to the accused, even if supervened after the filing of the recourse, must be applied. 
Article 78 Decision of the Supreme Court without Referral

1. The Supreme Court quashes the protested decision when:

a. The accusation does not constitute a crime, statute limitation has occurred or the prosecution was not permitted;

b. The decision concerns matters which are beyond the jurisdiction powers;

c. The sentence was adopted against a wrong person;

d. Results that for the same person and the same facts a previous decision was already adopted;

e. The same Supreme Court deems superfluous to refer the decision or can amend it on the basis of the already existing documentation.

Article 79 Referral to the Court of Appeal

1. In any other case different from those indicated in articles 76,77 and 78 the Supreme Court quashes the decision and refers the case to a Court of Appeal different from the one which made the decision or to the same Court composed by different judges.

2. In its referral the Supreme Court gives directions to be followed in reviewing the case.

3. The decision of the Court of Appeal can be protested according to the provisions of article 71 and following.

Article $80 \quad$ Scope of the Supreme Court Decision

1. The protested decision can be quashed in full or in part.

\section{Chapter 11 Review of Court Sentences}

\section{Article $81 \quad$ Cases of Revision}

1. It is permitted, at all times, the revision, in favor of the person sentenced for misdemeanors or felonies, of the final decision in the following cases:

a. When the facts on which the sentence is based cannot be reconciled with the facts established in another final decision;

b. When a judgment drawn up by a civil Court upon which the sentence is grounded has been quashed;

c. When facts, circumstances or documents, demonstrating the innocence of the sentenced person, which were not known before the sentence, are newly disclosed or emerged;

d. When it turns out by means of judicial assessment that the sentence was based on false testimonies, forged documents or any other fact of criminal nature which have been assessed by a final judicial decision;

e. When after a sentence for murder new evidentiary elements supervene or emerge according to which results that the death of the person did not occur;

f. When the sentence was adopted at the end of a process conducted without informing the accused by regular notifications or not giving him the possibility to appear so to deprive him of the right of defense or when a real impediment for appearing was not known or disregarded by the Court. 
Article 82 Right to Revision

1. The revision can be requested by the Saranwal, the sentenced person, or his or her defense counsel, or a close relative or heir.

2. In any instance, the request for revision must have the consent of the sentenced person unless the sentenced person is determined by the court to be incompetent, in which case the revision may be requested by the defense counsel or a close relative or heir without consent of the sentenced person.

Article 83 Revision Procedure

1. The petition for revision shall be forwarded to the Supreme Court together with the documents on which it is grounded.

2. Filing a revision petition does not stay the execution of the protested sentence except in the case of capital punishment.

3. The petition is evaluated by a Committee composed of a Supreme Court Justice and two appellate judges who are assigned by the Court's Presidents for consideration of the case.

4. The Attorney General shall express his opinion on the granting of the petition.

5. If the Committee finds that the petition is not convincingly grounded rejects the same, otherwise submits the petition to the Supreme Court delivering together with it the related file.

6. The decision of the Committee cannot be protested.

7. The Supreme Court upon reception of the petition and the related file shall fix a hearing ordering the notification of its decision to the requesting person and the attorney General that shall be served at least five days before the day of the hearing.

8. During the hearing the sentenced person or his defense counsel and the Saranwal express their views on the fundament of the petition.

9. In the event the Court approves the petition, it quashes the sentence and acquits the sentenced person if his innocence is obvious.

10. If the Court deems that the petition is not based on valid grounds, rejects the same.

11. When the Court finds that the case needs to be reassessed it shall dispatch the case to the Court that adopted the protested decision composed of different judges, or to another Court of the same level, giving it instructions for a proper review.

12. The review shall be conducted according to the rules applicable for normal hearings and the decision adopted replaces the previous one, remaining subject to protests which were allowed against the latter.

13. When as a consequence of the revision the sentenced person is acquitted the court, composed of different judges, shall order the restitution of the procedural expenses and any other cost paid as a result of the previous sentence. In case the concerned person is dead the restitution shall be made to his heirs.

14. Whenever a revision petition is rejected it is not allowed to file it again on the same grounds.

\section{Chapter 12 Execution of Courts' Final Decisions}

Article 84 Authority Responsible for Execution 
1. The execution of final decisions is the responsibility of the Saranwal indicated in paragraph 4 of article 8 .

\section{Article 85 Execution of Prison Punishments}

1. The Saranwal shall transmit to the Commander of the local police office the order to commit the sentenced person to prison when the latter is not already detained.

2. When the sentenced person is outside the jurisdiction of the local police office the police commander who has received the order shall forward it to the Commander of the police having jurisdiction on that place.

3. The same Saranwal can send the order directly to the said Commander.

4. If the sentenced person is already detained the Saranwal shall inform the Ministry of Justice about the sentence requesting its execution.

5. The above mentioned order and information shall contain personal particulars and whatever is needed to identify the person as well as the indications of the judicial decision and of the penalty imposed.

Article 86 Execution of Sanctions Alternative to Imprisonment

1. The Saranwal shall transmit to the Commander of the local police office the order for the execution of sanctions alternative to imprisonment.

2. The provisions of paragraphs 2,3 , and 4 of article 85 are applicable.

3. The police shall supervise the regularity of the execution and report to the Saranwal periodically about the behavior of the sentenced person.

4. If the sentenced person infringes the prescriptions contained in the execution order the Saranwal shall report the case to the competent Court which can replace the adopted sanction with a prison term of original duration.

\section{Article $87 \quad$ Execution of Fines}

1. The Saranwal shall transmit to the Ministry of Justice the order for the execution of fines.

2. The Ministry of Justice, directly or requesting the collaboration of financial institutions, shall collect the indicated sums which will be delivered to the Ministry of Finance.

\section{Article 88 Execution of Decisions for Confiscation of Objects and Assets}

1. The Saranwal shall transmit to the Command of the police having jurisdiction on the place where the objects and assets to be confiscated are located the related order containing the indications needed for the identification of the said objects and assets.

2. The confiscation and the destination of the objects and assets are performed by the police.

Article 89 Special Provisions for the Execution

1. The time spent under arrest before the final decision shall be deducted from the prison or alternative sanction term to be executed. 
2. When a prison sentence is to be executed towards a woman who is six months pregnant the Saranwal can stay the execution until four months after the delivering of the child.

3. When a prison sentence is to be executed towards a person who results to be mental insane the execution is stayed until his recovery. The Saranwal orders his transfer to a medical centre for the treatment of the mental illness. The time spent in intramural treatment shall be deducted from the prison term.

4. When a prison sentence is to be executed against a person affected by a serious physical illness, the Saranwal can stay the execution at the suggestion of a medical doctor who certifies that the imprisonment could be seriously prejudicial for the health of that person. The execution shall start as soon as the physical conditions of the concerned person permit the imprisonment. In this case no time is deducted from the prison term.

5. When a husband and his wife have been sentenced to prison for a term not exceeding one year, though for different charges, the Saranwal can stay the execution against one of them if he/she is not a recidivist and is supporting a child of less than fifteen years. The execution shall start when the child reaches the age of fifteen.

\section{Chapter 13 Conditional Release}

Article 90 Definition

1. Conditional release is the decision to put at liberty, under given conditions, a sentenced person before the expiration of his prison term, for a period equivalent to the duration of the same term.

\section{Article $91 \quad$ Conditions}

1. Conditional release can be granted to a person serving a prison term as consequence of one of more crimes who, during the execution of the penalty, has behaved in such a way to demonstrate his social rehabilitation.

2. This benefit can be granted only if the person has served three quarters of the term and at least nine months of imprisonment.

3. In case of life sentence the benefit can be granted only after fifteen years of imprisonment.

4. The decision is adopted ex officio or following the proposal of the Director General of the Prisons, by the Court having jurisdiction on the place where the sentenced person is detained.

5. In its decision the Court shall indicate the behavioral prescriptions that the person must follow in the future.

6. The police shall report periodically to the Saranwal about the behavior of the person under conditional release.

Article 92 Revocation

1. Conditional release is revoked if before the expiration of the original term the person commits another crime or commits gross violations of the prescriptions.

2. In case of revocation half of the time spent under conditional release is subtracted from the prison term. 
3. The revocation is decided by the same Court that has granted the benefit at the request of the Saranwal.

Article $93 \quad$ Procedure

1. Both the decisions for granting conditional release and for its revocation are adopted by the Court after having heard the concerned person and the Saranwal in an informal hearing.

2. Before adopting the decision for granting the release the Court shall also hear the Director of the prison in which the sentenced person has served the previous prison time.

\section{Chapter 14 Problems of Execution}

\section{Article 94 Competence and Procedure}

1. The Court indicated in paragraph 4 of article 8 is competent to consider, at the request of the sentenced person or of the Saranwal, any problem raised in the course of the execution.

2. Whenever the Court finds the raised problem of no or scarce relevance it declares it inadmissible, otherwise, after having informally heard the complainer, the Saranwal and, in case of imprisonment execution, the Director of the prison adopts a decision giving instructions for redressing the situation.

3. The decision is notified to the person under execution, the Saranwal and the Director of the prison.

4. The decision can be appealed to the Provincial Court only in case of a gross violation of human rights in question.

Article 95 Disputes on Property

1. When a dispute arises on the belonging of objects or assets seized or confiscated and the case cannot be solved by the penal Court on the basis of existing documents and evidence, the dispute shall be handled by the civil Court or traditional justice entities.

\section{Chapter 15 Miscellaneous Provisions}

Article 96 Interim Defense Counsel

1. Up to when in the Country there will be not available a sufficient number of defense counsels, as established in article 18, the suspect or the accused can make recourse to the assistance of an educated person having some knowledge of legal issues.

2. To this end the President of each Court shall institute a list of persons having the qualities indicated in the previous paragraph following the indications for the Capital of the Ministry of Justice and for Districts and Provincial Courts of Government Cases Department.

Article 97 Districts with no Functioning or Established Courts 
Whenever there is no district court established or functioning in a given district, the district court in the capital city of the Province will have territorial jurisdiction over all crimes committed within said district.

\section{Article 98 Effective Date and Duration}

1. This code shall become effective upon the execution of a Decree by the President of the Islamic Republic of Afghanistan published on the Official Gazette.

2. This code will remain in force until the enactment of rules of criminal procedure by the newly elected National Assembly, unless the National Assembly adopts this code with or without modifications.

3. Upon entry of the Presidential decree, any existing laws and decrees contrary to the provisions of this code are abrogated. 


\title{
THE CAIRO DECLARATION ON HUMAN RIGHTS IN ISLAM
}

\author{
Adopted and Issued at the Nineteenth Islamic Conference \\ of Foreign Ministers in Cairo \\ on 5 August 1990.
}

The Member States of the Organization of the Islamic Conference,

Reaffirming the civilizing and historical role of the Islamic Ummah which God made the best nation that has given mankind a universal and well-balanced civilization in which harmony is established between this life and the hereafter and knowledge is combined with faith; and the role that this Ummah should play to guide a humanity confused by competing trends and ideologies and to provide solutions to the chronic problems of this materialistic civilization.

Wishing to contribute to the efforts of mankind to assert human rights, to protect man from exploitation and persecution, and to affirm his freedom and right to a dignified life in accordance with the Islamic Shari'ah

Convinced that mankind which has reached an advanced stage in materialistic science is still, and shall remain, in dire need of faith to support its civilization and of a self-motivating force to guard its rights;

Believing that fundamental rights and universal freedoms in Islam are an integral part of the Islamic religion and that no one as a matter of principle has the right to suspend them in whole or in part or violate or ignore them in as much as they are binding divine commandments, which are contained in the Revealed Books of God and were sent through the last of His Prophets to complete the preceding divine messages thereby making their observance an act of worship and their neglect or violation an abominable sin, and accordingly every person is individually responsible - and the Ummah collectively responsible — for their safeguard.

Proceeding from the above-mentioned principles,

Declare the following:

Article 1

(a) All human beings form one family whose members are united by submission to God and descent from Adam. All men are equal in terms of basic human dignity and basic obligations and responsibilities, without any discrimination on the grounds of race, colour, language, sex, religious belief, political affiliation, social status or other considerations. True faith is the guarantee for enhancing such dignity along the path to human perfection.

(b) All human beings are God's subjects, and the most loved by him are those who are most useful to the rest of His subjects, and no one has superiority over another except on the basis of piety and good deeds. 
Article 2

(a) Life is a God-given gift and the right to life is guaranteed to every human being. It is the duty of individuals, societies and states to protect this right from any violation, and it is prohibited to take away life except for a Shari'ah-prescribed reason.

(b) It is forbidden to resort to such means as may result in the genocidal annihilation of mankind.

(c) The preservation of human life throughout the term of time willed by God is a duty prescribed by Shari'ah.

(d) Safety from bodily harm is a guaranteed right. It is the duty of the state to safeguard it, and it is prohibited to breach it without a Shari'ah-prescribed reason.

Article 3

(a) In the event of the use of force and in case of armed conflict, it is not permissible to kill non-belligerents such as old men, women and children. The wounded and the sick shall have the right to medical treatment; and prisoners of war shall have the right to be fed, sheltered and clothed. It is prohibited to mutilate dead bodies. It is a duty to exchange prisoners of war and to arrange visits or reunions of the families separated by the circumstances of war.

(b) It is prohibited to fell trees, to damage crops or livestock, and to destroy the enemy's civilian buildings and installations by shelling, blasting or any other means.

Article 4

Every human being is entitled to inviolability and the protection of his good name and honour during his life and after his death. The state and society shall protect his remains and burial place.

Article 5

(a) The family is the foundation of society, and marriage is the basis of its formation. Men and women have the right to marriage, and no restrictions stemming from race, colour or nationality shall prevent them from enjoying this right.

(b) Society and the State shall remove all obstacles to marriage and shall facilitate marital procedure. They shall ensure family protection and welfare.

Article 6

(a) Woman is equal to man in human dignity, and has rights to enjoy as well as duties to perform; she has her own civil entity and financial independence, and the right to retain her name and lineage.

(b) The husband is responsible for the support and welfare of the family.

\section{Article 7}

(a) As of the moment of birth, every child has rights due from the parents, society and the state to be accorded proper nursing, education and material, hygienic and moral care. Both the fetus and the mother must be protected and accorded special care.

(b) Parents and those in such like capacity have the right to choose the type of education they desire for their children, provided they take into consideration the interest and future of the children in accordance with ethical values and the principles of the Shari'ah. 
(c) Both parents are entitled to certain rights from their children, and relatives are entitled to rights from their kin, in accordance with the tenets of the Shari'ah.

\section{Article 8}

Every human being has the right to enjoy his legal capacity in terms of both obligation and commitment. Should this capacity be lost or impaired, he shall be represented by his guardian.

\section{Article 9}

(a) The quest for knowledge is an obligation, and the provision of education is a duty for society and the State. The State shall ensure the availability of ways and means to acquire education and shall guarantee educational diversity in the interest of society so as to enable man to be acquainted with the religion of Islam and the facts of the Universe for the benefit of mankind.

(b) Every human being has the right to receive both religious and worldly education from the various institutions of education and guidance, including the family, the school, the university, the media, etc., and in such an integrated and balanced manner as to develop his personality, strengthen his faith in God and promote his respect for and defence of both rights and obligations.

Article 10

Islam is the religion of unspoiled nature. It is prohibited to exercise any form of compulsion on man or to exploit his poverty or ignorance in order to convert him to another religion or to atheism.

\section{Article 11}

(a) Human beings are born free, and no one has the right to enslave, humiliate, oppress or exploit them, and there can be no subjugation but to God the Most-High.

(b) Colonialism of all types being one of the most evil forms of enslavement is totally prohibited. Peoples suffering from colonialism have the full right to freedom and selfdetermination. It is the duty of all States and peoples to support the struggle of colonized peoples for the liquidation of all forms of colonialism and occupation, and all States and peoples have the right to preserve their independent identity and exercise control over their wealth and natural resources.

\section{Article 12}

Every man shall have the right, within the framework of Shari'ah, to free movement and to select his place of residence whether inside or outside his country and, if persecuted, is entitled to seek asylum in another country. The country of refuge shall ensure his protection until he reaches safety, unless asylum is motivated by an act which Shari'ah regards as a crime.

\section{Article 13}

Work is a right guaranteed by the State and Society for each person able to work. Everyone shall be free to choose the work that suits him best and which serves his interests and those of society. The employee shall have the right to safety and security as well as to all other social guarantees. He may neither be assigned work beyond his capacity nor be subjected to compulsion or 
exploited or harmed in any way. He shall be entitled - without any discrimination between males and females - to fair wages for his work without delay, as well as to the holidays, allowances and promotions which he deserves. For his part, he shall be required to be dedicated and meticulous in his work. Should workers and employers disagree on any matter, the State shall intervene to settle the dispute and have the grievances redressed, the rights confirmed and justice enforced without bias.

Article 14

Everyone shall have the right to legitimate gains without monopolization, deceit or harm to oneself or to others. Usury (riba) is absolutely prohibited.

\section{Article 15}

(a) Everyone shall have the right to own property acquired in a legitimate way, and shall be entitled to the rights of ownership, without prejudice to oneself, others or to society in general. Expropriation is not permissible except for the requirements of public interest and upon payment of immediate and fair compensation

(b) Confiscation and seizure of property is prohibited except for a necessity dictated by law.

Article 16

Everyone shall have the right to enjoy the fruits of his scientific, literary, artistic or technical production and the right to protect the moral and material interests stemming therefrom, provided that such production is not contrary to the principles of Shari'ah.

Article 17

(a) Everyone shall have the right to live in a clean environment, away from vice and moral corruption, an environment that would foster his self-development; and it is incumbent upon the State and society in general to afford that right.

(b) Everyone shall have the right to medical and social care, and to all public amenities provided by society and the State within the limits of their available resources.

(c) The State shall ensure the right of the individual to a decent living which will enable him to meet all his requirements and those of his dependents, including food, clothing, housing, education, medical care and all other basic needs.

Article 18

(a) Everyone shall have the right to live in security for himself, his religion, his dependents, his honour and his property.

(b) Everyone shall have the right to privacy in the conduct of his private affairs, in his home, among his family, with regard to his property and his relationships. It is not permitted to spy on him, to place him under surveillance or to besmirch his good name. The State shall protect him from arbitrary interference.

(c) A private residence is inviolable in all cases. It will not be entered without permission from its inhabitants or in any unlawful manner, nor shall it be demolished or confiscated and its dwellers evicted.

Article 19

(a) All individuals are equal before the law, without distinction between the ruler and the 
ruled.

(b) The right to resort to justice is guaranteed to everyone.

(c) Liability is in essence personal.

(d) There shall be no crime or punishment except as provided for in the Shari'ah.

(e) A defendant is innocent until his guilt is proven in a fair trial in which he shall be given all the guarantees of defence.

Article 20

It is not permitted without legitimate reason to arrest an individual, or restrict his freedom, to exile or to punish him. It is not permitted to subject him to physical or psychological torture or to any form of humiliation, cruelty or indignity. Nor is it permitted to subject an individual to medical or scientific experimentation without his consent or at the risk of his health or of his life. Nor is it permitted to promulgate emergency laws that would provide executive authority for such actions.

Article 21

Taking hostages under any form or for any purpose is expressly forbidden.

Article 22

(a) Everyone shall have the right to express his opinion freely in such manner as would not be contrary to the principles of the Shari'ah.

(b) Everyone shall have the right to advocate what is right, and propagate what is good, and warn against what is wrong and evil according to the norms of Islamic Shari'ah.

(c) Information is a vital necessity to society. It may not be exploited or misused in such a way as may violate sanctities and the dignity of Prophets, undermine moral and ethical values or disintegrate, corrupt or harm society or weaken its faith.

(d) It is not permitted to arouse nationalistic or doctrinal hatred or to do anything that may be an incitement to any form of racial discrimination.

Article 23

(a) Authority is a trust; and abuse or malicious exploitation thereof is absolutely prohibited, so that fundamental human rights may be guaranteed.

(b) Everyone shall have the right to participate, directly or indirectly in the administration of his country's public affairs. He shall also have the right to assume public office in accordance with the provisions of Shari'ah.

Article 24

All the rights and freedoms stipulated in this Declaration are subject to the Islamic Shari'ah.

Article 25

The Islamic Shari'ah is the only source of reference for the explanation or clarification to any of the articles of this Declaration.

Cairo, 14 Muharram 1411H

5 August 1990 


\title{
UNIVERSAL DECLARATION OF HUMAN RIGHTS
}

\author{
Preamble
}

Whereas recognition of the inherent dignity and of the equal and inalienable rights of all members of the human family is the foundation of freedom, justice and peace in the world,

Whereas disregard and contempt for human rights have resulted in barbarous acts which have outraged the conscience of mankind, and the advent of a world in which human beings shall enjoy freedom of speech and belief and freedom from fear and want has been proclaimed as the highest aspiration of the common people,

Whereas it is essential, if man is not to be compelled to have recourse, as a last resort, to rebellion against tyranny and oppression, that human rights should be protected by the rule of law,

Whereas it is essential to promote the development of friendly relations between nations,

Whereas the peoples of the United Nations have in the Charter reaffirmed their faith in fundamental human rights, in the dignity and worth of the human person and in the equal rights of men and women and have determined to promote social progress and better standards of life in larger freedom,

Whereas Member States have pledged themselves to achieve, in cooperation with the United Nations, the promotion of universal respect for and observance of human rights and fundamental freedoms,

Whereas a common understanding of these rights and freedoms is of the greatest importance for the full realization of this pledge,

Now, therefore,

The General Assembly

proclaims

This Universal Declaration of Human Rights

as a common standard of achievement for all peoples and all nations, to the end that every individual and every organ of society, keeping this Declaration constantly in mind, shall strive by teaching and education to promote respect for these rights and freedoms and by progressive measures, national and international, to secure their universal and effective recognition and observance, both among the peoples of Member States themselves and among the peoples of territories under their jurisdiction.

Article I 
All human beings are born free and equal in dignity and rights. They are endowed with reason and conscience and should act towards one another in a spirit of brotherhood.

\section{Article 2}

Everyone is entitled to all the rights and freedoms set forth in this Declaration, without distinction of any kind, such as race, colour, sex, language, religion, political or other opinion, national or social origin, property, birth or other status.

Furthermore, no distinction shall be made on the basis of the political, jurisdictional or international status of the country or territory to which a person belongs, whether it be independent, trust, non-self-governing or under any other limitation of sovereignty.

Article 3

Everyone has the right to life, liberty and security of person.

\section{Article 4}

No one shall be held in slavery or servitude; slavery and the slave trade shall be prohibited in all their forms.

\section{Article 5}

No one shall be subjected to torture or to cruel, inhuman or degrading treatment or punishment.

\section{Article 6}

Everyone has the right to recognition everywhere as a person before the law.

\section{Article 7}

All are equal before the law and are entitled without any discrimination to equal protection of the law. All are entitled to equal protection against any discrimination in violation of this Declaration and against any incitement to such discrimination.

\section{Article 8}

Everyone has the right to an effective remedy by the competent national tribunals for acts violating the fundamental rights granted him by the constitution or by law.

\section{Article 9}

No one shall be subjected to arbitrary arrest, detention or exile. 
Article 10

Everyone is entitled in full equality to a fair and public hearing by an independent and impartial tribunal, in the determination of his rights and obligations and of any criminal charge against him.

\section{Article 11}

(1) Everyone charged with a penal offence has the right to be presumed innocent until proved guilty according to law in a public trial at which he has had all the guarantees necessary for his defence.

(2) No one shall be held guilty of any penal offence on account of any act or omission which did not constitute a penal offence, under national or international law, at the time when it was committed. Nor shall a heavier penalty be imposed than the one that was applicable at the time the penal offence was committed.

\section{Article 12}

No one shall be subjected to arbitrary interference with his privacy, family, home or correspondence, nor to attacks upon his honour and reputation. Everyone has the right to the protection of the law against such interference or attacks.

\section{Article 13}

(1) Everyone has the right to freedom of movement and residence within the borders of each State.

(2) Everyone has the right to leave any country, including his own, and to return to his country.

\section{Article 14}

(1) Everyone has the right to seek and to enjoy in other countries asylum from persecution.

(2) This right may not be invoked in the case of prosecutions genuinely arising from nonpolitical crimes or from acts contrary to the purposes and principles of the United Nations.

Article 15

(1) Everyone has the right to a nationality.

(2) No one shall be arbitrarily deprived of his nationality nor denied the right to change his nationality.

Article 16 
(1) Men and women of full age, without any limitation due to race, nationality or religion, have the right to marry and to found a family. They are entitled to equal rights as to marriage, during marriage and at its dissolution.

(2) Marriage shall be entered into only with the free and full consent of the intending spouses.

(3) The family is the natural and fundamental group unit of society and is entitled to protection by society and the State.

\section{Article 17}

(1) Everyone has the right to own property alone as well as in association with others.

(2) No one shall be arbitrarily deprived of his property.

\section{Article 18}

Everyone has the right to freedom of thought, conscience and religion; this right includes freedom to change his religion or belief, and freedom, either alone or in community with others and in public or private, to manifest his religion or belief in teaching, practice, worship and observance.

Article 19

Everyone has the right to freedom of opinion and expression; this right includes freedom to hold opinions without interference and to seek, receive and impart information and ideas through any media and regardless of frontiers.

Article 20

(1) Everyone has the right to freedom of peaceful assembly and association.

(2) No one may be compelled to belong to an association.

Article 21

(1) Everyone has the right to take part in the government of his country, directly or through freely chosen representatives.

(2) Everyone has the right to equal access to public service in his country.

(3) The will of the people shall be the basis of the authority of government; this will shall be expressed in periodic and genuine elections which shall be by universal and equal suffrage and shall be held by secret vote or by equivalent free voting procedures.

Article 22 
Everyone, as a member of society, has the right to social security and is entitled to realization, through national effort and international co-operation and in accordance with the organization and resources of each State, of the economic, social and cultural rights indispensable for his dignity and the free development of his personality.

\section{Article 23}

(1) Everyone has the right to work, to free choice of employment, to just and favourable conditions of work and to protection against unemployment.

(2) Everyone, without any discrimination, has the right to equal pay for equal work.

(3) Everyone who works has the right to just and favourable remuneration ensuring for himself and his family an existence worthy of human dignity, and supplemented, if necessary, by other means of social protection.

(4) Everyone has the right to form and to join trade unions for the protection of his interests.

\section{Article 24}

Everyone has the right to rest and leisure, including reasonable limitation of working hours and periodic holidays with pay.

\section{Article 25}

(1) Everyone has the right to a standard of living adequate for the health and well-being of himself and of his family, including food, clothing, housing and medical care and necessary social services, and the right to security in the event of unemployment, sickness, disability, widowhood, old age or other lack of livelihood in circumstances beyond his control.

(2) Motherhood and childhood are entitled to special care and assistance. All children, whether born in or out of wedlock, shall enjoy the same social protection.

Article 26

(1) Everyone has the right to education. Education shall be free, at least in the elementary and fundamental stages. Elementary education shall be compulsory. Technical and professional education shall be made generally available and higher education shall be equally accessible to all on the basis of merit.

(2) Education shall be directed to the full development of the human personality and to the strengthening of respect for human rights and fundamental freedoms. It shall promote understanding, tolerance and friendship among all nations, racial or religious groups, and shall further the activities of the United Nations for the maintenance of peace. 
(3) Parents have a prior right to choose the kind of education that shall be given to their children.

Article 27

(1) Everyone has the right freely to participate in the cultural life of the community, to enjoy the arts and to share in scientific advancement and its benefits.

(2) Everyone has the right to the protection of the moral and material interests resulting from any scientific, literary or artistic production of which he is the author.

Article 28

Everyone is entitled to a social and international order in which the rights and freedoms set forth in this Declaration can be fully realized.

Article 29

(1) Everyone has duties to the community in which alone the free and full development of his personality is possible.

(2) In the exercise of his rights and freedoms, everyone shall be subject only to such limitations as are determined by law solely for the purpose of securing due recognition and respect for the rights and freedoms of others and of meeting the just requirements of morality, public order and the general welfare in a democratic society.

(3) These rights and freedoms may in no case be exercised contrary to the purposes and principles of the United Nations.

Article 30

Nothing in this Declaration may be interpreted as implying for any State, group or person any right to engage in any activity or to perform any act aimed at the destruction of any of the rights and freedoms set forth herein.

G.A. res. 217A (III), U.N. Doc A/810 at 71 (1948)

Adopted on December 10, 1948

by the General Assembly of the United Nations (without dissent) 